$$
\begin{aligned}
& \text { UNIVERSIDADE DE SÃO PAULO } \\
& \text { FACULDADE DE MEDICINA DE RIBEIRÃO PRETO }
\end{aligned}
$$

Dissomia uniparental e mosaicismo somático como mecanismos de alterações epigenéticas do imprinting genômico

Filipe Brum Machado

Ribeirão Preto 
Filipe Brum Machado

\section{Dissomia uniparental e mosaicismo somático como mecanismos de alterações epigenéticas do imprinting genômico}

Tese apresentada à Faculdade de Medicina de Ribeirão Preto da Universidade de São Paulo para obtenção do título de Doutor em Ciências. Área de Concentração: Genética

Orientadora: Profa. Dra. Ester Silveira Ramos 
AUTORIZO A DIVULGAÇÃO TOTAL OU PARCIAL DESTE TRABALHO, POR QUALQUER MEIO CONVENCIONAL OU ELETRÔNICO, PARA FINS DE ESTUDO E PESQUISA, DESDE QUE CITADA A FONTE.

FICHA CATALOGRÁFICA

Machado, Filipe Brum.

Dissomia uniparental e mosaicismo somático como mecanismos de alterações epigenéticas do imprinting genômico, 2012.

155p. il.; $30 \mathrm{~cm}$

Tese de Doutorado, apresentada à Faculdade de Medicina de

Ribeirão Preto/USP - Área de concentração: Genética.

Orientadora: Ramos, Ester Silveira

1.Imprinting genômico; 2. Dissomia uniparental; 3. Síndrome de BeckwithWiedemann; 4. Hemihiperplasia isolada; 5. Síndrome de Silver-Russell ; 6. Mosacismo. 
Filipe Brum Machado

DISSOMIA UNIPARENTAL E MOSAICISMO SOMÁTICO COMO MECANISMOS DE ALTERAÇÕES EPIGENÉTICAS DO IMPRINTING GENÔMICO

Tese apresentada à Faculdade de Medicina de Ribeirão Preto da Universidade de São Paulo para obtenção do título de Doutor em Ciências. Área de Concentração: Genética

\section{BANCA EXAMINADORA}

Data da Defesa:

Profa. Dra. Ester Silveira Ramos

Julgamento:

Assinatura:

Prof. Dr.

Julgamento:

Assinatura:

Prof. Dr.

Julgamento:

Assinatura:

Prof. Dr.

Julgamento:

Assinatura:

Prof. Dr.

Julgamento:

Assinatura: 
"Para descobrir caminhos é necessário sair dos trilhos" (Albert Einstein 1879-1955) "Todo o interesse na doença e na morte é apenas uma outra forma de interesse pela vida" (Thomas Mann 1875-1955) 
Dedico este trabalho aos meus pais Celso e Ioni, aos meus irmãos Fabricio e Carolina e à minha noiva Manuela 


\section{AGRADECIMENTOS}

Agradeço a Deus por ter me concedido saúde e por sempre iluminar o meu caminho.

À Profa. Dra. Ester Silveira Ramos pela oportunidade e orientação. Pelos ensinamentos valiosos, e por toda confiança depositada em mim.

Ao Prof. Dr. Enrique Medina-Acosta pelo apoio, amizade e pela colaboração enriquecedora deste trabalho.

À Profa. Dra. Susana Marina Chuva de Sousa Lopes pela oportunidade e orientação durante o período de doutorado sanduíche na Universidade de Leiden, Holanda.

Ao grupo de pesquisa da Profa. Dra. Margaret de Castro pela colaboração, especialmente a Dra. Fernanda Borchers Coeli Lacchini e ao técnico de laboratório Rogério.

Aos assistidos e responsáveis legais que doaram amostras como voluntários, em benefício da ciência.

Aos amigos do grupo: Cristiana, Hélida, Karina, Murilo, Matheus, Thiago e Sarah pelo convívio harmonioso, pelos ensinamentos e incentivo.

Aos amigos ex/pós-graduandos do bloco C: Adriana, Anderson, Andrea, Ciro, Fernanda, Flávia, Rafaella, Silvina e Vivian.

Aos técnicos do bloco C: Luis, Marli, Paulo, Sílvio e Reginaldo.

Aos funcionários dona Mara, Luciano, Cristiano, Sr. Carlos e Sr. Wilson.

Aos amigos de outros grupos de pesquisa: Álvaro, André, Andressa, Angélica, Augusto, Cláudia, Daniel, Edward, Flávia, Francielle, Gilberto, Gilvan, Gustavo, Jaqueline, Jhimmy, João, João Paulo, Julia, Juliana, Kleiton, Larissa, Maurício, Vanessa.

Aos amigos do Núcleo de Diagnóstico e Investigação Molecular: Antonio, Graziela, Maria, Laís, Luciana, Thaís, Thiago e Viviane.

Aos amigos da Universidade de Leiden: Ana, David, Hatef e Liesbeth.

À Profa. Dra. Lúcia Regina Martelli e a todos os docentes do departamento de Genética que contribuíram para minha formação.

Ao chefe do Departamento de Genética Prof. Dr. Aguinaldo Luiz Simões, ao coordenador da Pós-Graduação Prof. Dr. Ademilson Espencer Egea Soares e às secretárias, Maria Aparecida, Silvia e Susie. 
À Fundação de Amparo à Pesquisa do Estado de São Paulo (FAPESP), pela concessão da bolsa de doutorado e pelo apoio financeiro para a realização deste trabalho.

À Cordenação de Aperfeiçoamento de Pessoal de Nível Superior (CAPES), pela concessão da bolsa de doutorado (e doutorado sanduíche) e pelo apoio financeiro para a realização deste trabalho.

À Fundação de Apoio ao Ensino, Pesquisa e Assistência do Hospital das Clínicas da Faculdade de Medicina de Ribeirão Preto da Universidade de São Paulo (FAEPA) pelo apoio financeiro.

Aos meus pais Celso e loni, e aos meus irmãos Fabricio e Carolina, por não medirem esforços pela minha felicidade.

À minha noiva Manuela pelo companheirismo, cumplicidade, carinho e compreensão mesmo nos momentos difíceis.

E a todos aqueles que acreditam e investem na ciência brasileira. 
MACHADO, FB. Dissomia uniparental e mosaicismo somático como mecanismos de alterações epigenéticas do imprinting genômico, 2012. 155p. Tese (Doutorado) Faculdade de Medicina de Ribeirão Preto, Universidade de São Paulo.

O imprinting genômico é um processo regulado epigeneticamente que faz com que os alelos sejam expressos de acordo com a sua origem parental. No cromossomo 11 (11p15.5), existem duas regiões controladoras de imprinting (ICR1 e ICR2), que controlam a expressão de genes marcados (imprinted). Os padrões de metilação dessas regiões podem ser alterados pela dissomia uniparental (DUP), que ocorre quando parte de ou um cromossomo inteiro do mesmo par de homólogos é herdado de somente um genitor. Erros mitóticos podem gerar mosaicismo com uma linhagem de células com DUP e a outra biparental. As síndromes de Silver-Russell (SSR) e Beckwith-Wiedemann (SBW) são doenças de alterações do imprinting genômico, envolvendo os cromossomos 7 (SSR) e 11 (SSR e SBW). A Hemihiperplasia Isolada $(\mathrm{HHI})$ parece corresponder a uma forma mais leve da SBW.. No presente trabalho, foi realizada uma varredura in silico para busca de novos microssatélites nos cromossomos 7 e 11, e selecionados seis do tipo tetra ou pentanucleotídeos, no cromossomo 7, e 12, no cromossomo 11. O perfil de metilação nas ICRs foi verificado por três técnicas distintas: MS-MLPA, DESM-RT e por uma nova estratégia desenvolvida neste trabalho denominada DESM-QFPCR. Foram avaliados 32 pacientes com SBW, $16 \mathrm{HHI}, 20$ com SSR e seus pais, quando disponíveis, além de um paciente com fenótipo aparentemente normal com cariótipo 46,XX/46,XY e cuja placenta apresentou displasia mesenquimal placentária (DMP) a qual está associada à SBW. Os novos marcadores apresentaram alta taxa de heterozigose (média de 70\%), e ausência das características indesejáveis dos dinucleotídeos predominantemente utilizados para detecção de DUP. Seis marcadores estão entre genes controlados pelas ICRs 1 e 2. A DUP paterna do cromossomo 11 (DUPpat Cr11), sempre restrita a $11 \mathrm{p} 15.5$, foi responsável por $13 \%$ dos casos de $\mathrm{HHI}$ e $19 \%$ dos de SBW. As alterações estruturais foram confirmadas por minissequenciamento quantitativo de SNPs e por MS-MLPA. Um paciente apresentou duplicação paterna abrangendo ambas as ICRs. Uma deleção não descrita anteriormente no gene $C D K N 1 C$ foi observada em uma paciente e sua mãe. Para os pacientes com DUPpat Cr11, foram investigados microssatélites em 13 autossomos e nos cromossomos sexuais para detecção de mosaicismo global. Apenas o paciente com DMP apresentou mosaicismo [células androgenéticas (25-30\%) e biparentais], sugerindo evento de dupla fertilização. Nos pacientes com SSR, foi observada hipometilação na ICR1 em $25 \%$ dos casos. Para a SBW, foi observada hipermetilação na ICR1 e hipometilação na ICR2 em 6\% e 42\% dos casos, respectivamente. Os casos com DUPpat Cr11 apresentaram alteração de metilação em ambas as ICRs. As frequências de alterações (epi) genéticas encontradas foram semelhantes às previamente descritas na literatura para as SBW, SSR e HHI. Neste trabalho, foi desenvolvida uma nova técnica para estudo de metilação do DNA de ICRs e testados marcadores microssatélites inéditos na região $11 \mathrm{p} 15$, que quando comparados com metodologias mais tradicionais de avaliação, como DESM-RT e MS-MLPA, mostraram elevada correlação dos resultados. Os achados mostram a complexidade da etiologia das doenças estudadas no presente trabalho e os dados moleculares serão imprescindíveis para o aconselhamento genético adequado para cada caso em particular e suas famílias.

Palavras-chave: Imprinting genômico, síndrome de Beckwith-Wiedemann, síndrome de Silver-Russell, Hemihiperplasia Isolada, Mosaicismo, Dissomia Uniparental. 
MACHADO, FB. Uniparental disomy and somatic mosaicism: mechanisms for epigenetic deregulation of genomic imprinting, 2012. 155p. Ph. D. Thesis - Faculdade de Medicina de Ribeirão Preto, Universidade de São Paulo.

Genomic imprinting is a epigenetically regulated process where the alleles are expressed in terms of their parental origin. On chromosome 11 (11p15.5) there are two regions controlling imprinting (ICR1 and ICR2), which control imprinted gene expression. The methylation patterns in these regions may be altered by uniparental disomy (UPD), which occurs when part or whole chromose is inherited from only one parent. Mitotic errors can lead to mosaicism with a cell line with DUP and other, biparental. The Silver-Russell syndrome (SRS) and Beckwith-Wiedemann syndrome (BWS) are diseases of abnormal genomic imprinting, involving chromosomes 7 (SSR) and 11 (SRS and BWS). The Isolated Hemihiperplasia $(\mathrm{IHH})$ seems to correspond to a milder form of the SBW. In the present study, we performed an in silico scan to search for new microsatellites on chromosomes 7 and 11, and selected six tetra- and/or pentanucleotides on chromosome 7, and 12 on chromosome 11. The pattern of methylation in ICRs was verified by three different techniques: MS-MLPA, DESM-RT and a new strategy developed in this work called DESMQFPCR. We evaluated 32 patients with BWS, HHI 16, with 20 SSR and their parents, when available, and one patient with apparently normal phenotype with karyotype 46, XX/46, XY and whose placenta showed placental mesenchymal dysplasia (PMD) which is associated with SBW. The new markers showed a high heterozygosity rate (average $70 \%$ ), and absence of undesirable characteristics of dinucleotides, predominantly used for detection of DUP. Six markers spans genes controlled by the ICRs 1 and 2. The paternal UPD for chromosome 11 (UPDpat Cr11), all restricted to $11 \mathrm{p} 15.5$, was responsible for $13 \%$ of cases of $\mathrm{HHI}$ and $19 \%$ of the SBW. Structural changes were confirmed by quantitative SNaPshot sequencing of SNPs and MS-MLPA. One patient had paternal duplication encompassing both ICRs. A not previously described deletion in the gene CDKN1C was observed in one patient and her mother. For patients with DUPpat Cr11, microsatellites were investigated in 13 autosomes and sex chromosomes to detect wide mosaicism. Only patients with DMP showed mosaicism [androgenetic cells (25-30\%) and biparental], suggesting double fertilization. In patients with SRS, ICR1 hypomethylation was observed in $25 \%$ of cases. For BWS, ICR 1 hypermethylation and in ICR2 hypomethylation were observed $6 \%$ and $42 \%$ of cases, respectively. All cases with UPDpat Cr11 presented abnormal methylation in both ICRs. The (epi) genetic change frequencies were similar to those previously described in the literature for BWS, SRR andIHH. In the present work, we developed a new technique to study DNA methylation of ICRs and tested novel microsatellite markers in the $11 \mathrm{p} 15$ region, which showed high correlation of results, when compared with more traditional methods such as RT-DESM and MS-MLPA. The results show the complex etiology of these diseases and the molecular data are essential for appropriate patient and families genetic counseling.

Keywords: Genomic Imprinting, Beckwith-Wiedemann syndrome, Silver-Russell syndrome, Isolated Hemihyperplasia, mosaicism, uniparental disomy. 


\section{LISTA DE ABREVIATURAS E SIGLAS}

\begin{tabular}{|c|c|}
\hline C & citosina \\
\hline CDKN1C & cyclin-dependent kinase inhibitor $1 C$ (inibidor de quinase dependente de ciclina 1C) \\
\hline CpG & citosina-fosfato-guanina \\
\hline Ct & $\begin{array}{l}\text { ciclo threshold - número do ciclo no qual o nível de fluorescência emitido pela } \\
\text { amostra amplificada atingiu o nível arbitrário }\end{array}$ \\
\hline CTCF & fator de ligação СССТC \\
\hline DESM-RT & digestão enzimática sensível à metilação associada à PCR em tempo real \\
\hline $\begin{array}{l}\text { DESM- } \\
\text { QFPCR }\end{array}$ & digestão enzimática sensível à metilação associada à PCR quantitativa fluorescente \\
\hline DMP & displasia mesenquimal placentária \\
\hline DMR & differentially methylated megion (região diferencialmente metilada) \\
\hline DNA & deoxyribonucleic acid (ácido desoxirribonucleico) \\
\hline DNMT & enzima DNA metiltransferase \\
\hline DUP & dissomia uniparental \\
\hline DUPmat Cr7 & dissomia uniparental do cromossomo 7 materno \\
\hline DUPpat Cr11 & dissomia uniparental do cromossomo 11 paterno \\
\hline $\mathbf{G}$ & guanina \\
\hline HHI & Hemihiperplasia isolada \\
\hline ICR & imprinting control region (região controladoras de imprinting) \\
\hline IGF2 & insulin-like growth factor 2 (fator de crescimento semelhante à insulina 2) \\
\hline Mb & megabases \\
\hline KCNQ1 & potassium channel, voltage-gated, kqt-like subfamily, member 1 \\
\hline KCNQ1OT1 & KCNQ1-overlapping transcript 1 \\
\hline $\mathrm{MgCl} 2$ & cloreto de magnésio \\
\hline $\mathbf{m M}$ & milimolar \\
\hline MS-MLPA & Methylation-specific Multiplex Ligation-dependent Probe Amplification \\
\hline OMIM & online mendelian inheritance in man \\
\hline QF-PCR & Quantitative Fluorescent Polymerase Chain Reaction \\
\hline SBW & síndrome de Beckwith-Wiedemann \\
\hline SSR & síndrome de Silver-Russell \\
\hline uL & microlitro \\
\hline$\mu g$ & micrograma \\
\hline
\end{tabular}




\section{SUMÁRIO}

I. INTRODUÇÃO

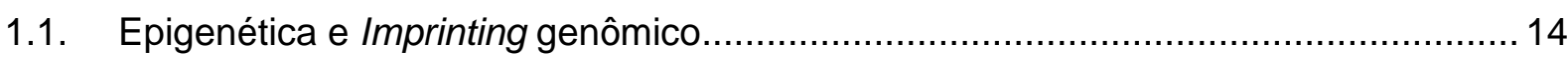

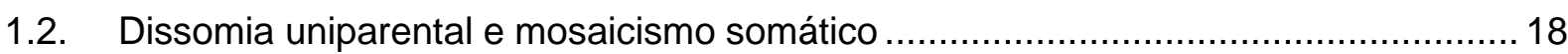

1.3. Alterações (epi)genéticas na síndrome de Beckwith-Wiedemann e na Hemihiperplasia

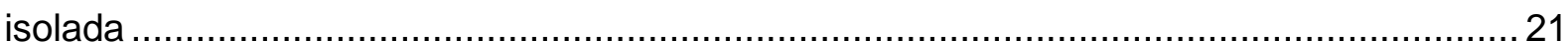

1.4. Alterações (epi) genéticas na síndrome de Silver-Russell .......................................29

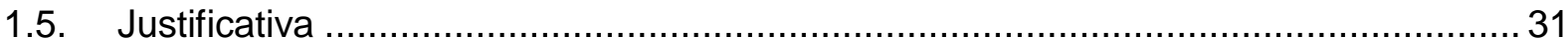

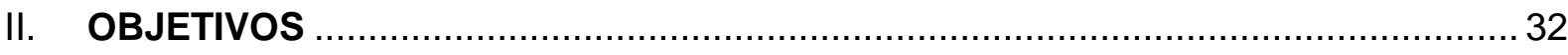

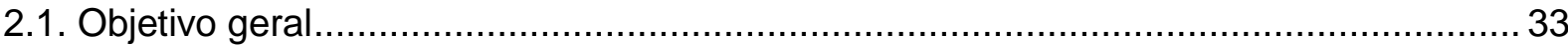

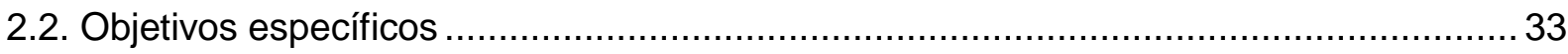

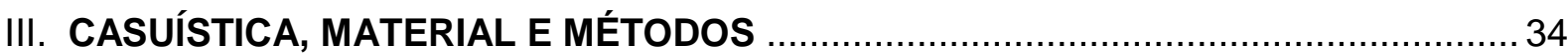

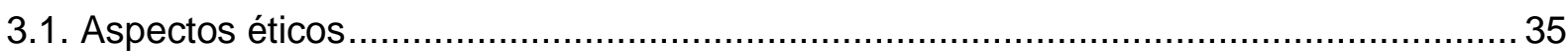

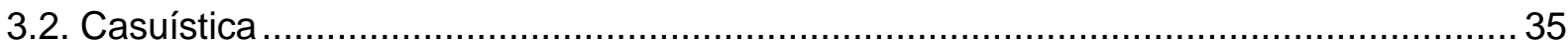

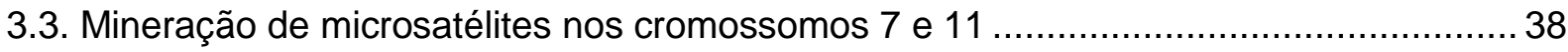

3.4. Critérios de seleção para loci potencialmente polimórficos .............................................. 39

3.6. Construção de um mapa genético para os cromossomos 7 e 11 ................................... 39

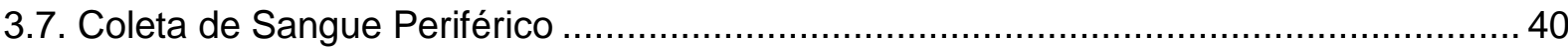

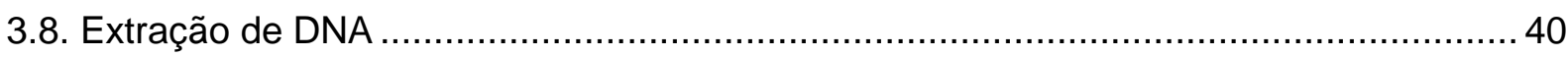

3.9. QF-PCR dos novos marcadores microssatélites ................................................... 40

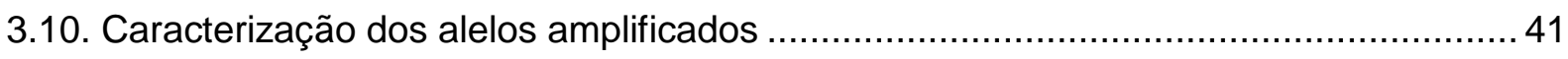

3.11. Marcadores para análise de dissomia uniparental global ..................................... 42

3.12. Amplificação de múltiplas sondas dependente de ligação-metilação específica (MS-

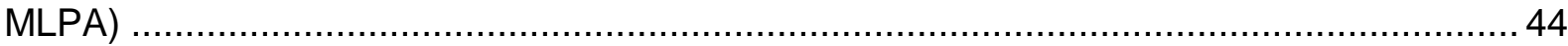

3.13. Digestão Enzimática Sensível à Metilação Associada à PCR em Tempo Real (DESM-

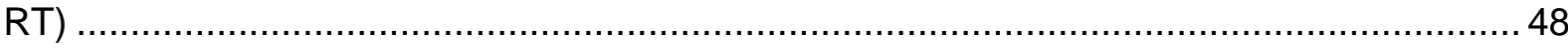

3.14. Digestão Enzimática Sensível à Metilação Associada à PCR Quantitativa Fluorescente

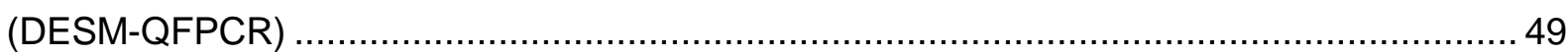

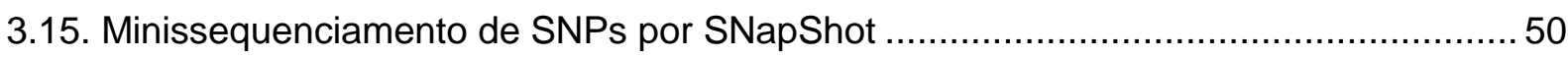

IV. RESULTADOS

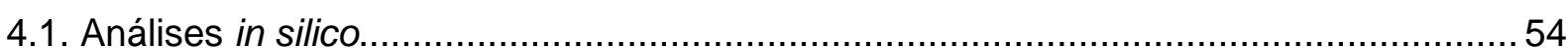

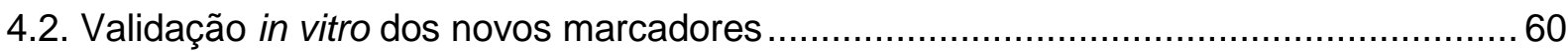

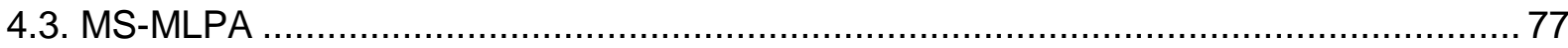




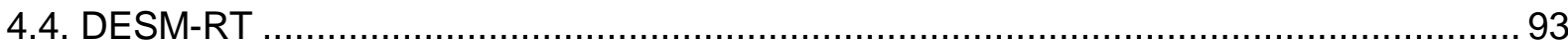

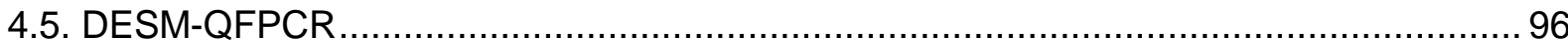

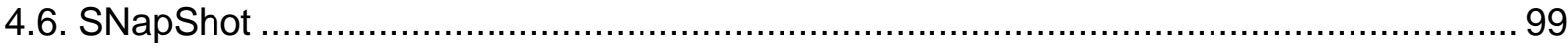

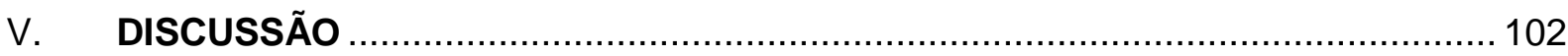

5.1. Novos marcadores microssatélites para os cromossomos 11 e 7 ............................... 103

5.2. Alterações genéticas na SBW, HHI e SSR........................................................... 106

5.3. Alterações (epi) genéticas no caso de displasia mesenquimal placentária.................. 110

5.4. Alterações epigenéticas na SSR, SBW e HHI...................................................... 112

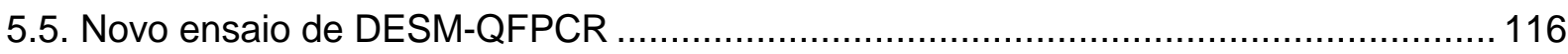

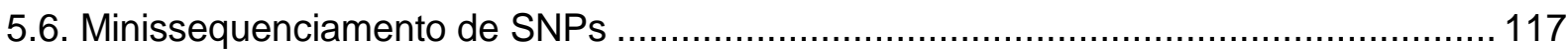

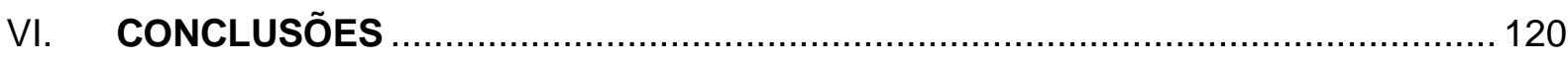

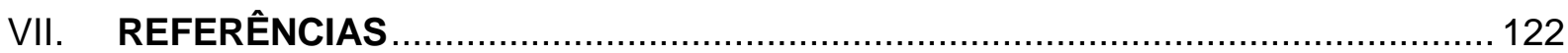

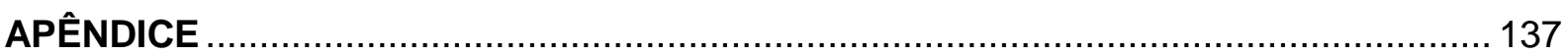

ANEXO 


\section{INTRODUÇÃO}

\subsection{Epigenética e Imprinting genômico}

Epigenética é a ciência que estuda os mecanismos potencialmente herdáveis que controlam a expressão gênica, sem alteração na estrutura primária do DNA. Em nível molecular, modificações covalentes de bases citosinas e histonas, e mudanças no posicionamento de nucleossomos, são geralmente consideradas como os principais mecanismos epigenéticos. Os mesmos são fundamentais para a regulação de muitos processos celulares, incluindo a expressão gênica e de microRNAs, interações DNA-proteína, supressão da mobilidade de elementos transponíveis, diferenciação celular, embriogênese, inativação do cromossomo $\mathrm{Xe}$ imprinting (marcação) genômico (Portela;Esteller, 2010).

$\mathrm{O}$ imprinting genômico é um processo regulado epigeneticamente que faz com que os genes sejam expressos de acordo com a origem parental, ao contrário do que acontece na maioria dos genes, onde ambos os alelos dos cromossomos homólogos são expressos (Ferguson-Smith, 2011). O alelo reprimido de certos genes marcados (imprinted) não está completamente silenciado e possui alguma atividade residual, enquanto outros apresentam expressão monoalélica apenas em certos tecidos (imprinting tecido-específico) (Horsthemke, 2010).

No início dos anos 1980, experimentos-chave com camundongos mostraram a inviabilidade de se produzir embriões a partir de genomas exclusivamente paternos ou maternos, sugerindo que os genomas de mamíferos possuem genes que são marcados diferencialmente nos genomas parentais (McGrath;Solter, 1983; Surani et al., 1984; Barton et al., 1984). Oócitos de camundongos recém-fertilizados foram manipulados por meio da remoção e substituição dos pronúcleos paternos por pronúcleos maternos para gerar um embrião diplóide ginogenético/partenogenético. Alternativamente, os pró-núcleos maternos foram substituídos por paternos para gerar um embrião diplóide androgenético. Até a primeira metade do período gestacional, embriões partenogenéticos desenvolveram tecidos predominantemente de origem embrionária, com pouco desenvolvimento de tecido extra-embrionário, enquanto que embriões androgenéticos desenvolveram predominantemente material extra-embrionário e possuiam componentes embrionários subdesenvolvidos, sugerindo que a ausência ou a expressão excessiva de genes imprinted eram responsáveis pela falha no desenvolvimento (Surani et al., 1984; Barton et al., 1984). 
Pela manipulação desses genes foi possível tornar viável o desenvolvimento de camundongos partenogenéticos até a fase adulta, mostrando que o imprinting genômico é a única barreira para o desenvolvimento a termo, e que o imprinting paterno previne a partenogênese garantindo que a contribuição paterna seja obrigatória nos descendentes (Kono et al., 2004).

Em humanos, aproximadamente 60 genes conhecidos estão sujeitos ao imprinting genômico (www.geneimprint.com). Além destes, outros 154 genes foram preditos utilizando ferramentas de bioinformática (Luedi et al., 2007). Uma característica notável de genes marcados é que eles raramente são encontrados sozinhos; cerca de $80 \%$ estão fisicamente próximos em aglomerados com outros genes imprinted. Estes grupos (ou clusters) de genes são regulados por regiões controladoras de imprinting conhecidas como ICRs (do inglês, Imprinting Control Regions) (Reik; Walter, 2001).

Um dos principais mecanismos envolvidos no imprinting genômico é a metilação do DNA. Aproximadamente $70-80 \%$ das citosinas seguidas por guaninas na mesma fita de DNA ( $\mathrm{C}_{\text {fosfato }} \mathrm{G}$ ou $\mathrm{CpG}$ ) estão metiladas nas células somáticas humanas (Chen; Riggs, 2011). As DNAs metiltransferases (DNMTs) de mamíferos catalisam a transferência de um grupo metil para citosina a partir de S-adenosil-Lmetionina. Entre as três DNMTs enzimaticamente ativas, a DNMT1 atua na manutenção do conteúdo de metilação, com preferência para sítios hemimetilados como os gerados pela replicação do DNA. As DNMT3A e DNMT3B são metiltransferases de novo que atuam no DNA não metilado e são responsáveis por estabelecer padrões de metilação nos estágios iniciais do desenvolvimento (Figura 1) (Chen; Riggs, 2011).

A 5-metilcitosina sofre desaminação espontaneamente transformando-se em timina, resultando na sub-representação de CpG no genoma (21\% do esperado no genoma humano) (Illingworth; Bird, 2009). O DNA globalmente metilado, pobre em CpG, é interrompido por ilhas CpG (CGls), que possuem em média 1.000 pares de bases de comprimento, apresentam grande quantidade de $\mathrm{G}$ e $\mathrm{C}$, e ausência de metilação no DNA. Aproximadamente $70 \%$ da região promotora dos genes está associada à CGIs, tornando este o tipo de promotor o mais comum no genoma de vertebrados e enfatizando a forte correlação entre CGls e o início da transcrição (Deaton; Bird, 2011). 
A grande maioria dos genes imprinted possui CGls e apresenta metilação diferencial entre os alelos parentais, mas as regiões diferencialmente metiladas (DMRs, do inglês Differentially Methylated Regions) podem ter propriedades diferentes. Por exemplo, a metilação do DNA em algumas DMRs é introduzida nas células germinativas parentais e mantida em todas as fases de desenvolvimento, enquanto outras apresentam alterações consideráveis na metilação durante o desenvolvimento, adquirindo metilação tecido-específica. Algumas DMRs são metiladas no gene inativo, enquanto outras são metiladas no gene ativo (Reik; Walter, 2001). O papel de modificações de histonas no controle do imprinting genômico é menos claro, no entanto as DMRs são caracterizadas pelo acúmulo assimétrico de diferentes modificações de histonas sobre os dois cromossomos parentais (Radford et al., 2011).

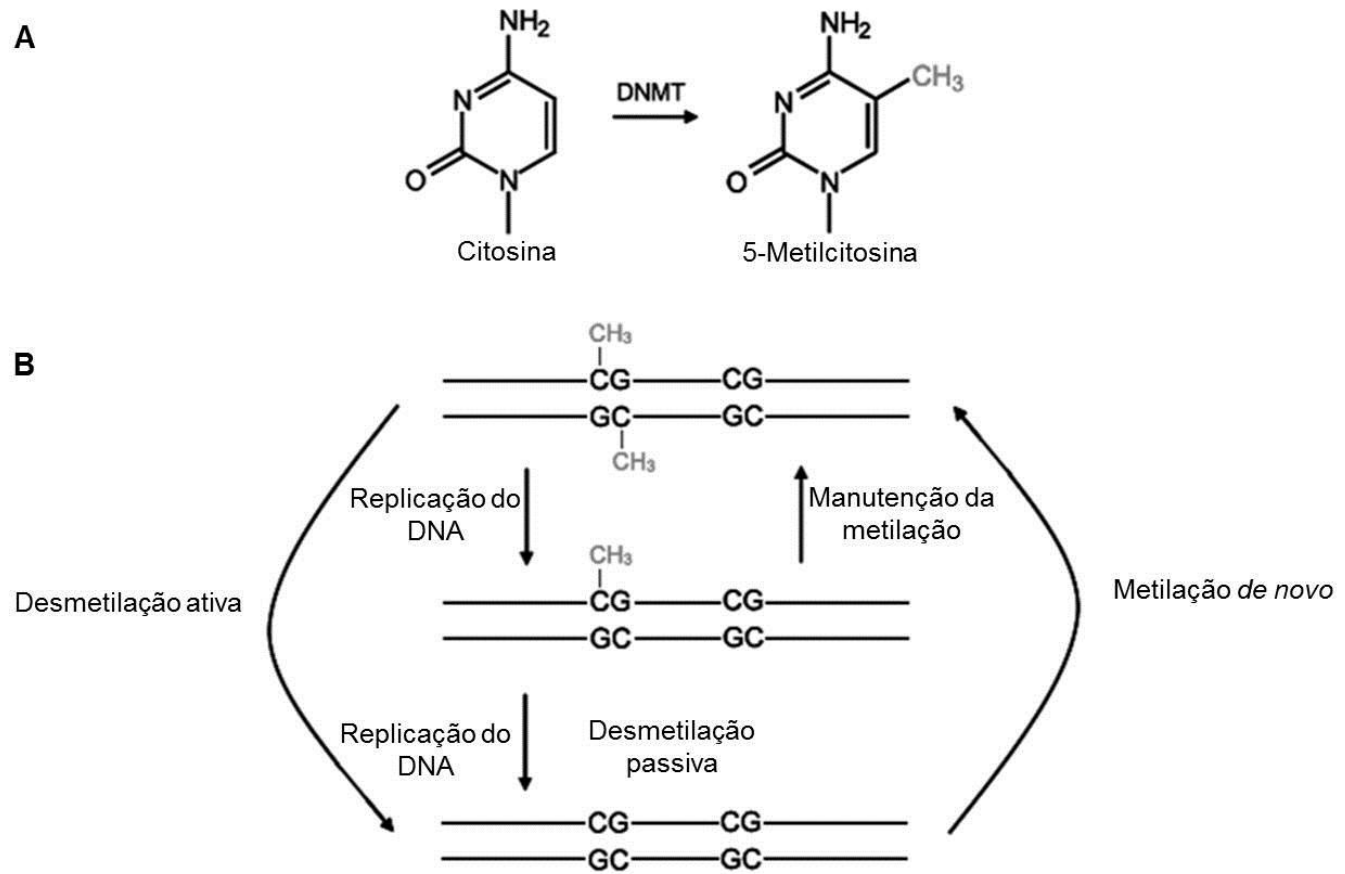

Figura 1. Resumo dos mecanismos envolvidos na metilação e desmetilação do DNA em mamíferos. (A) As DNMTs catalisam a adição covalente de um grupo metil para o C-5 da citosina. (B) A maior parte da metilação de citosina ocorre dentro de dinucleotídeos CpGs e uma distinção pode ser feita entre duas atividades da DNMT: metilação de manutenção e de novo. Padrões de metilação são estabelecidos durante os estágios iniciais do desenvolvimento pelas metiltranferases DNMT3A e DNMT3B, sendo mantidos pela DNMT1, que atua preferencialmente nos sítios $\mathrm{CpG}$ hemimetilados gerados pela replicação do DNA. A desmetilação do DNA pode ser de forma passiva, pela falha de metilação de manutenção após a replicação do DNA, ou ativa, por processos independentes da replicação. As enzimas responsáveispela desmetilação ativa não têm sido conclusivamente identificadas em mamíferos (modificado de Chen; Riggs, 2011). 
O imprinting genômico é alterado de modo característico durante o ciclo de vida do organismo (Figura 2). As marcações são "estabelecidas" durante o desenvolvimento das células germinativas em espermatozóides ou oócitos. Após a fertilização, elas são "mantidas" e segregam no organismo em desenvolvimento. Nas células germinativas do novo organismo, as marcações são "apagadas" em um estágio inicial (Reik; Walter, 2001).

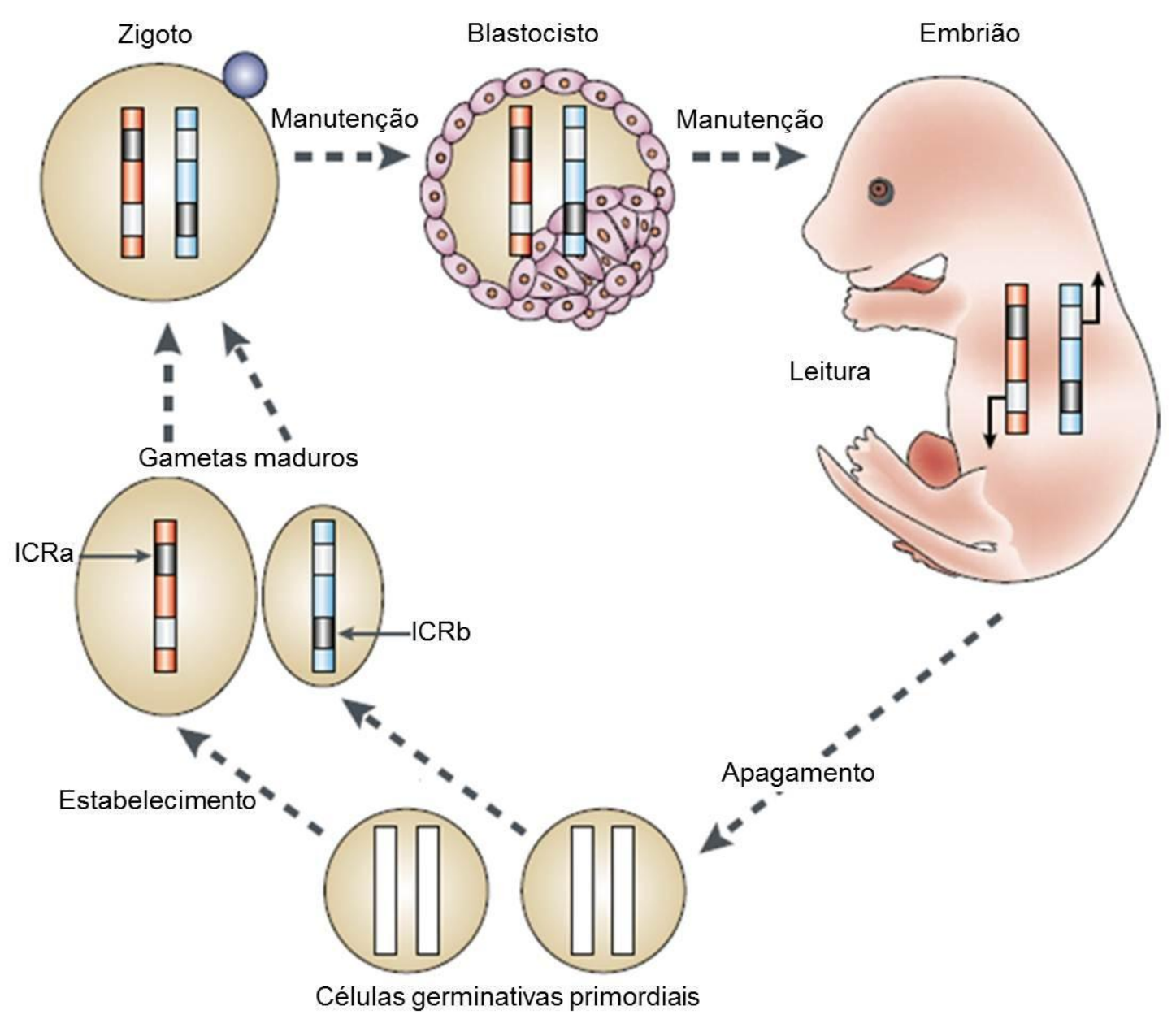

Figura 2. Ciclo da metilação no imprinting genômico. Apagamento, estabelecimento e manutenção de marcas de metilação nas ICRs em células germinativas e no desenvolvimento embrionário. Cinza indica modificação e branco indica que não há modificação nos alelos correspondentes. Os cromossomos parentais estão marcados em azul (paterno) e vermelho (materno). As setas nos cromossomos do embrião indicam a transcrição gênica (modificado de Reik; Walter, 2001). 
Semelhante a outros processos biológicos, o apagamento, estabelecimento e manutenção do imprinting estão sujeitos a erros, os quais podem resultar em um cromossomo paterno com padrão de imprinting materno ou um cromossomo materno com padrão paterno. Portanto, um erro de imprinting leva à ativação de um alelo que deveria estar silenciado ou silencia um alelo que deveria estar ativo. Como consequência, nenhum ou ambos os alelos de um gene imprinted estão ativos (Horsthemke, 2010). Esse tipo de alteração pode ser resultado de uma epimutação primária ou secundária. O termo epimutação refere-se a uma metilação alterada no DNA ou a uma alteração no padrão de modificações de histonas. A epimutação primária ocorre na ausência de uma mutação no DNA e a secundária pode ocorrer como consequência direta de uma mutação no DNA. A mutação do DNA pode afetar um elemento controlador de imprinting em um determinado locus no mesmo cromossomo (mutação cis-atuante) ou afetar um fator de regulação codificado em outro lugar no genoma (mutação trans-atuante) (Horsthemke, 2006; Horsthemke, 2010). Outro fator secundário que altera os padrões de metilação de genes imprinted é a dissomia uniparental.

\subsection{Dissomia uniparental e mosaicismo somático}

A dissomia uniparental (DUP) ocorre quando parte de ou um cromossomo inteiro do mesmo par de homólogos é herdado de somente um genitor. A DUP pode causar anormalidades fenotípicas por diferentes consequências: alterações do imprinting genômico; homozigose para uma característica recessiva e mosaicismo somático (Siegel; Slavotinek, 2005). Denomina-se isodissomia uniparental quando o mesmo cromossomo está presente em duplicata devido a um erro na separação das cromátides irmãs na segunda divisão meiótica. A heterodissomia uniparental ocorre quando os dois cromossomos homólogos de um dos pais estão presentes, devido a um erro na primeira divisão meiótica (Siegel; Slavotinek, 2005).

O termo "'dissomia uniparental" foi cunhado por Engel (1980) apenas hipoteticamente como um mecanismo causador de doença em humanos, mas a confirmação veio apenas em 1987 quando uma menina foi diagnosticada com fibrose cística devido a DUP materna (DUPmat) do cromossomo 7 (Spence et al., 
1988). Cerca de 40 exemplos de transmissão de características recessivas foram relatados, entre 32 tipos conhecidos de DUPs (Engel, 2006).

A DUP constitucional pode ocorrer durante a meiose. Neste caso, todas as células no organismo adulto possuem a mesma região da DUP como resultado de um evento na linhagem germinativa. No entanto, este evento também pode ser adquirido em uma porção de células somáticas por meio da divisão mitótica, e ser um importante passo para o desenvolvimento e progressão em diferentes tipos de câncer (Tuna et al., 2009).

A seguir são listados diferentes mecanismos que podem causar DUP:

1) Resgate da dissomia a partir de zigoto trissômico resultante da fertilização de um oócito dissômico por um espermatozoide normal. Neste caso, há perda por segregação de um dos três cromossomos, que pode levar a uma correção cromossômica da condição normal ou à DUP (Figura 3A).

2) Complementação gamética: devido à não-disjunção, o oócito materno mantém duas cópias do cromossomo materno. Este oócito é então fertilizado por um espermatozoide nulissômico (Figura 3B).

3) Erro pós-fertilização: ocorre depois da fertilização, no zigoto em desenvolvimento ou embrião, causando mosaicismo contendo células com DUP e biparentais (Figura 3C).

4) Resgate da dissomia a partir de zigoto monossômico: um gameta nulissômico fertiliza um gameta haploide e logo ocorre a complementação somática para estabelecer a diploidia (Figura 3D).

$O$ termo mosaicismo deve ser diferenciado de quimerismo. Um mosaico contém células geneticamente diferentes originadas de um único zigoto, enquanto que uma quimera contém células de diferentes zigotos que foram fundidos. Mosaicismo resulta de um erro mitótico durante as primeiras divisões do blastômero ou em estágios posteriores, podendo resultar em euploidia ou aneuploidia (Malan et al., 2006). O mosaicismo somático corresponde à presença de duas populações geneticamente distintas de células somáticas em um mesmo organismo e pode ser causado por mutações no DNA, alterações epigenéticas, aberrações cromossômicas e a reversão espontânea de mutações herdadas (Youssoufian; Pyeritz, 2002). 
A Resgate da dissomia a

partir de zigoto trissômico
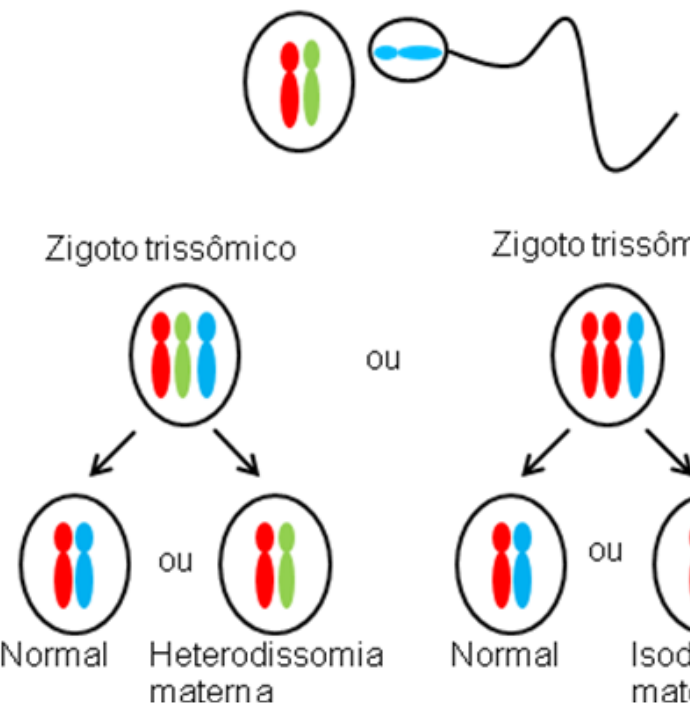

Zigoto trissômico

ou

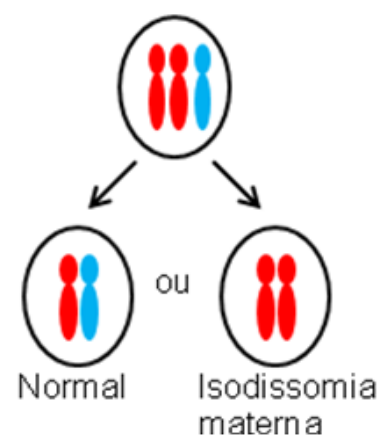

B Complementaçẫo gamética

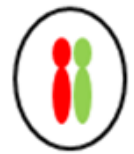

Näo-disjunçẫo nameiose materna

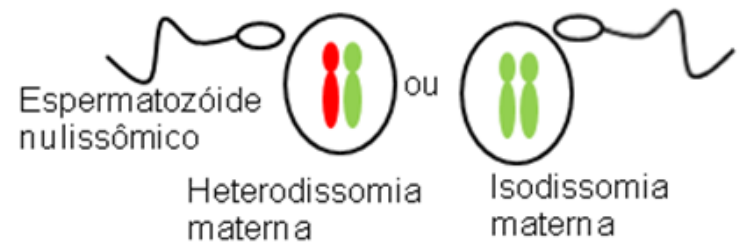

D Resgate da dissomia a partir de zigoto monossômico

C Erro pós-fertilizaçẫo
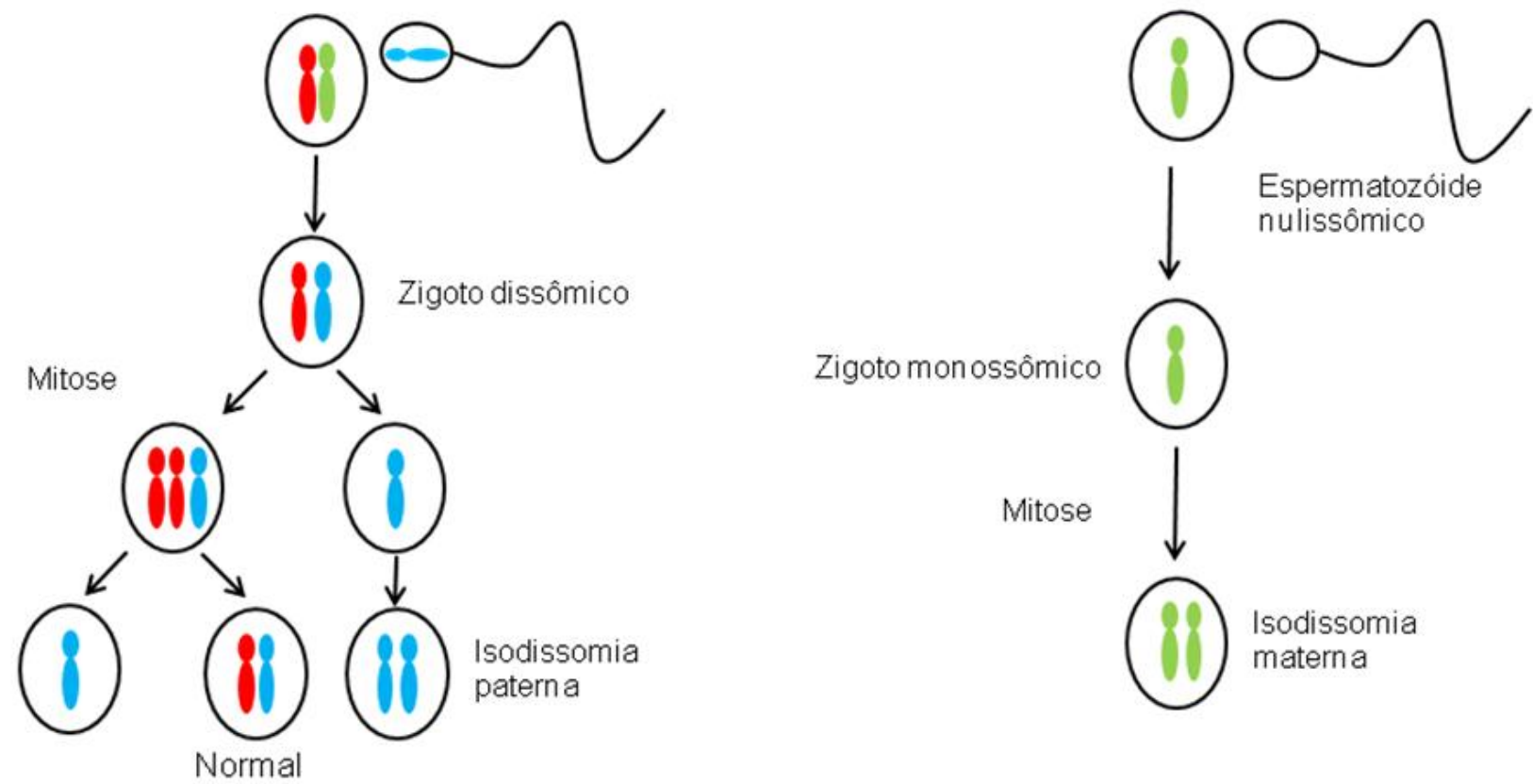

Zigoto monossômico

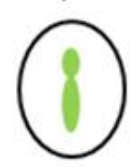

Mitose

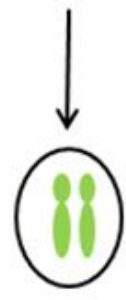

Isodissomia materna

Figura 3. Mecanismos de formação da dissomia uniparental e suas consequências (adaptado de Siegel; Slavotinek, 2005; Kotzot; Utermann, 2005).

A extensão do mosaicismo depende do estágio pós-zigótico em que o evento ocorreu. Recombinação somática em um estágio muito precoce, seguido por morte preferencial de uma determinada linhagem celular, pode levar a um grau de mosaicismo não detectável (Das et al., 2000). Para as formas segmental, complexa ou de mosaicismo global (para todo o genoma) sempre deve haver a ocorrência 
concomitante de recombinação meiótica ou mitótica, segregação anormal e a subsequente correção, se necessário (Kotzot, 2008).

Na divisão de células com uma constiuição cromossômica (cariótipo) normal, a ocorrência de DUP deve ser considerada como uma mutação de novo e o risco de recorrência pode ser negligenciável (Yamazawa et al., 2010).Recentemente, novas tecnologias tais como microarranjos de polimorfismos de nucleotídeo simples (SNP) têm facilitado a detecção de DUP, pois permite a detecção precisa de regiões homozigotas/heterozigotas ao longo de todos os cromossomos (Yamazawa et al., 2010).

É importante salientar que a DUP em si não interfere com o processo de imprinting genômico. No entanto, se o par de cromossomos afetado possui um gene imprinted, os dois alelos deste gene serão inativos ou ativos, dependendo da origem parental dos cromossomos. A presença de deleção ou de duas cópias ativas de um gene imprinted, no entanto, frequentemente interfere com o desenvolvimento e crescimento normais (Horsthemke, 2010). A primeira demonstração de que a DUP pode estar associada a uma doença de imprinting em humanos foi na observação da síndrome de Prader-Willi, a qual envolve o cromossomo 15 (Nicholls et al., 1989). Por sua vez, DUP paterna (DUPpat) em mosaico do cromossomo 11 é responsável por cerca de $20 \%$ dos casos da síndrome de Beckwith-Wiedemann (Wekesberg 2010), uma doença modelo de alteração epigenética do imprinting genômico.

\subsection{Alterações (epi) genéticas na síndrome de Beckwith-Wiedemann e na Hemihiperplasia isolada}

A Síndrome de Beckwith-Wiedemann (SBW; OMIM\#130650) é uma síndrome de hiperpercrescimento, com uma incidência de aproximadamente um em 13.700 nascidos vivos. A designação original para esta doença, EMG (exomphalos, macroglossia and gigantism) baseou-se na apresentação dos achados clínicos em um paciente de onfalocele (exônfalo), macroglossia e gigantismo (macrossomia). Outras características principais associadas à SBW são: sulco horizontal no lóbulo e endentações na orelha, hemihiperplasia corpórea, viceromegalia (por exemplo, do fígado, rim e pâncreas) e desenvolvimento de tumores na infância (Gomes; Ramos, 2003; Choufani et al., 2010). A SBW apresenta outros achados clínicos menos frequentes como: hipoglicemia neonatal; cardiomegalia e idade óssea avançada 
(Weksberg et al., 2010). Alterações genéticas e epigenéticas em genes reguladores do crescimento mapeados no cromossomo 11 (11p15.5) são as principais responsáveis pela SBW. A SBW em geral (85\%) ocorre de forma esporádica, mas casos familiais são responsáveis por $15 \%$ dos registros (Weksberg et al., 2010). O risco de recorrência está relacionado ao tipo de mutação (genética ou epigenética) e a origem parental da alteração (Choufani et al.,2010).

A região 11p15 possui dois domínios, cada um regulado por uma ICR. A ICR1 está mais próxima ao telômero e também é designada como a ICR telomérica. A ICR2 é mais distal, denominada centromérica. A ICR1 também é conhecida como H19DMR e a ICR2 também é chamada de KvDMR1. Nessas regiões estão presentes genes imprinted e genes expressos bialélicos (Figura 4).

A ICR1 consiste em uma região metilada no alelo paterno e não metilada no alelo materno, localizada em uma ilha CpG upstream ao gene $H 19$, a qual controla a expressão deste gene e do gene codificador do fator de crescimento semelhante à insulina (IGF2, do inglês, insulin-like growth fator 2). O gene H19 expressa um mRNA não codificador imprinted (expressão materna). Recentemente, foi descoberto que o locus do gene $H 19$ também possui um gene maternalmente expresso, que transcreve em sentido oposto ao H19, O novo gene, denominado HOTS (ㅂ19 opposite tumor supressor) codifica uma proteína supressora tumoral presente no núcleo e nucléolo (Onyango; Feinberg 2011). O gene IGF2, paternalmente expresso, produz um polipeptídeo de cadeia única que medeia a ação do hormônio de crescimento, a estimulação da acção da insulina e está envolvido no desenvolvimento e crescimento (Eggerman, 2009).

A ICR1 regula a expressão de $H 19$ e IGF2, funcionando como um elemento insulador. O locus materno não metilado permite a ligação do fator de trancrição CTCF (CCCTC-binding factor), uma proteína insuladora. Esta ligação bloqueia o acesso do IGF2 ao enhancer localizado downstream ao gene $H 19$, silenciando o IGF2. O gene H19, por sua vez, materno utiliza o enhancer e é transcrito (Figura 4). O lucus paterno metilado, impede a ligação do CTCF e permite que o enhancer acesse o promotor do IGF2 e que o gene seja expresso, enquanto o H19 é silenciado (Hark et al., 2000) (Figura 4).

Ganho de metilação é responsável por 2-7\% dos casos de SBW (Weksberg et al., 2010). Diferentes mecanismos causam alteração de imprinting na ICR1. Deleções de elementos que atuam em cis na ICR1 têm sido encontradas em 
pacientes com SBW, como hipermetilação desta região (Sparago et al., 2004; Demars et al., 2011). As deleções removem uma a duas sequências alvo para o CTCF, resultando em hipermetilação residual da região, expressão bialélica do IGF2, silenciamento do $H 19$ e co-segregação com a SBW. Recentemente foram identificados novos fatores potencialmente envolvidos na regulação da ICR1, os quais são fatores de transcrição da rede de pluripotência. Foram identificadas, na ICR1, mutações no sítio de ligação para os fatores OCT4 (fator de trancrição 1, classe 5 domínio POU) e SOX2 (fator de transcrição SOX-2) em pacientes com hipermetilação da ICR1. Em todos os casos, o fenótipo da SBW segregou com a transmissão da mutação através da linhagem germinativa materna. Estas observações sugerem que estes elementos atuantes em cis são responsáveis pela manutenção do imprinting na ICR1 (Demars et al., 2010; Poole et al., 2011). A hipermetilação da ICR1 pode ocorrer por epimutações esporádicas independentemente de alteração na sequência do DNA, provavelmente em estágios pós-zigóticos, com baixo risco de recorrência (Cerrato et al., 2008).

A ICR2 regula a expressão de outro grupo de genes imprinted. Esta ICR está localizada no íntron 11 do gene KCNQ1 (potassium voltage-gated channel subfamily KQT member 1) que codifica um canal de potássio necessário para a fase de repolarização do potencial de acção cardíaco. A ICR2 está metilada somente no alelo materno (Figura 4) (Eggerman et al., 2008). O alelo paterno não metilado, expressa o gene que codifica um RNA não codificante KCNQ10T1 (KCNQ1 opposite strand/antisense transcript 1), que provavelmente reprime o gene CDKN1C (cyclin-dependent kinase inhibitor 1C), o qual por sua vez codifica um regulador negativo do ciclo celular (Guo et al., 2011).

Mutações de perda de função no gene CDKN1C são responsáveis por cerca de $10 \%$ da etiologia da SBW e perfazem aproximadamente $40 \%$ dos casos hereditários (Choufani et al., 2010), . Curiosamente, foi descrito recentemente que uma nova mutação de ganho de função no CDKN1C causa a síndrome IMAGe (intrauterine growth restriction, metaphyseal dysplasia, adrenal hypoplasia congenita and genital anomalies) (Arboleda et al., 2012), caracterizada por restrição do crescimento intra-uterino, displasia metafisária, hipoplasia adrenal congênita e anomalias genitais. 
Perda de metilação materna na ICR2 é observada em mais de $50 \%$ dos pacientes com SBW, representando assim a alteração mais comum da síndrome. $O$ efeito desta hipometilação no desenvolvimento da SBW se deve provavelmente à redução na expressão do CDKN1C (Enklaar et al., 2006).

A DUP paterna de 11 p15 (DUPpat 11) é responsável por cerca de $20 \%$ dos casos de SBW, estando presente na forma de mosaico com células biparentais e com DUPpat (Slatter et al., 1994;Catchpoole et al., 1997). Casos com dissomia se estendendo para 11q têm sido descritos (Dutly et al., 1998; Cooper et al., 2007). Embora a região da DUP varie, ela sempre evolve as regiões ICR1 e ICR2, resultando na super-dosagem de genes paternalmente ativos como o IGF2 e silenciamento de genes maternalmente ativos como o CDKN1C, os quais contribuem para um fenótipo anormal. Há uma relação direta entre a proporção de DUPpat 11 e a severidade da expressão fenotípica (Itoh et al., 2000; Smith et al., 2007). Translocações, inversões e duplicações na região 11 p15.5 estão presentes em <2\% dos pacientes SBW (Russo et al., 2006; Algar et al., 2007). Mosaicismo genômico, com células biparentais e DUPpat para diversos cromossomos além do 11 em um mesmo indivíduo têm sido relatados em pacientes com SBW associada à displasia mesenquimal placentária (DMP) (Figura 5) (Giurgea et al., 2006; Wilson et al., 2008). Em um terço dos casos com DMP, a criança apresenta SBW (H'mida et al., 2008).

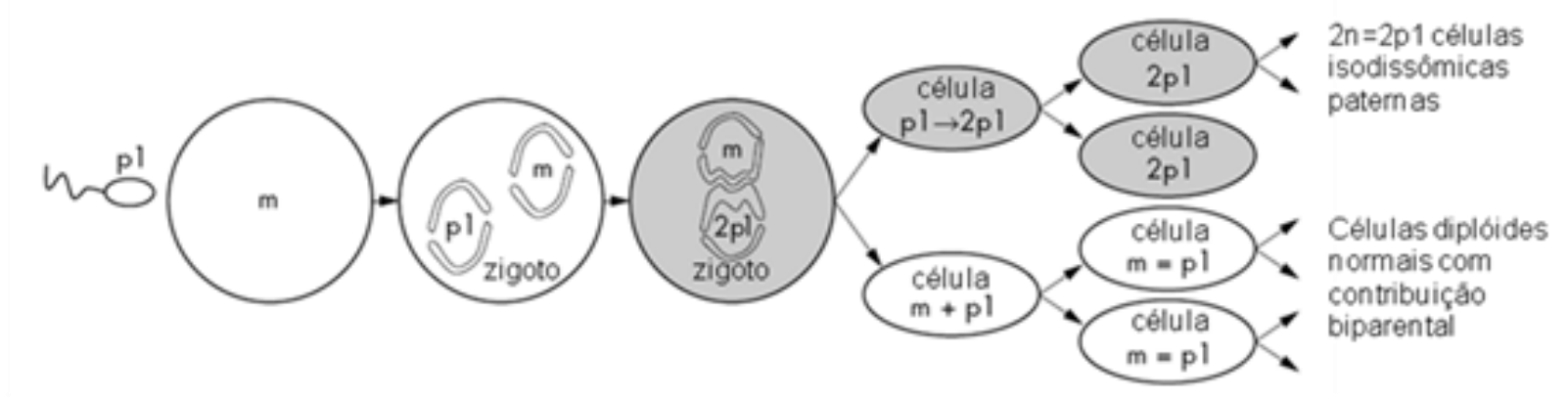

Figura 5. Representação esquemática do mais provável mecanismo responsável por mosaicismo. (m) genoma haploide materno; ( $n$ ) 23 cromossomos; ( 1 1) genoma haploide paterno; ( $p--2 p 1)$ o genoma haploide paterno replica e gera uma célula diploide (2n), a qual é isodissômica (2p1) (Adaptado de Giurgea et al., 2006). 


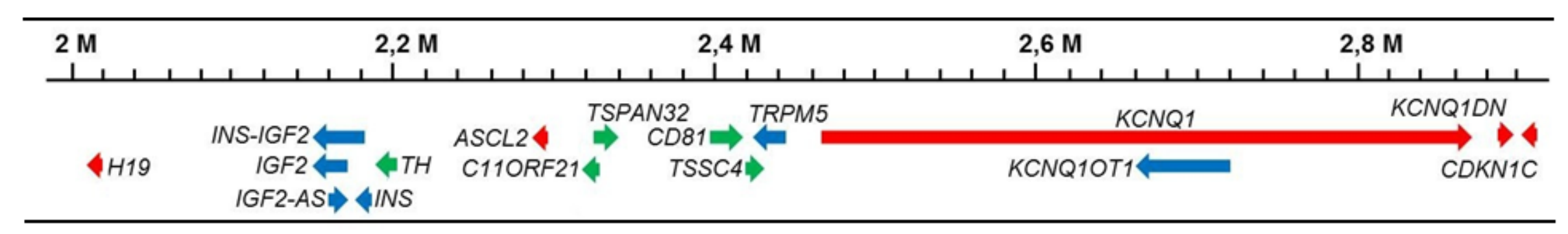

M

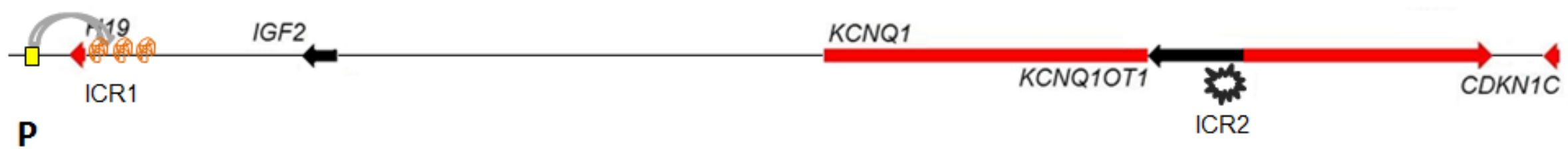

$\mathbf{P}$

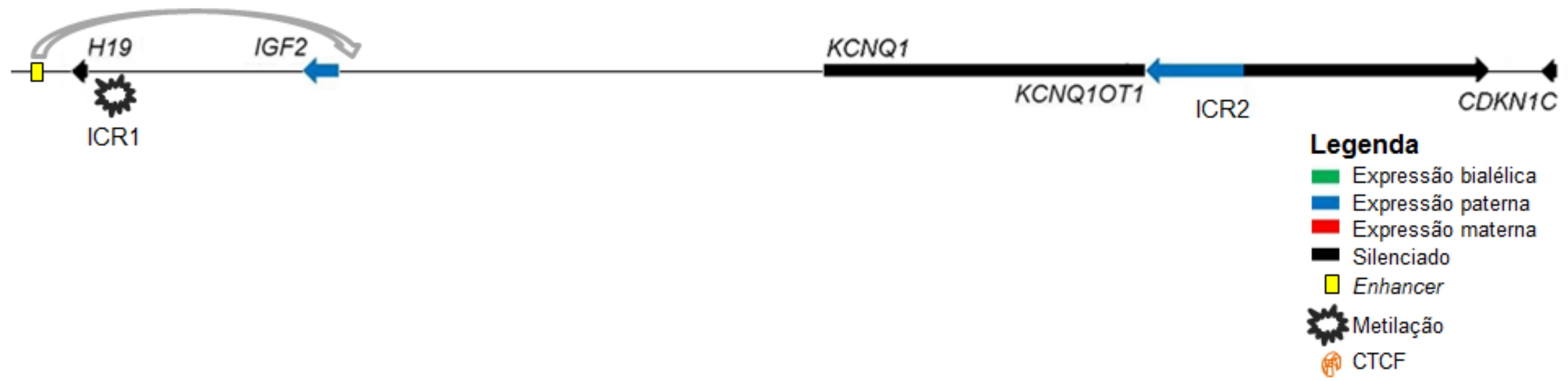

Figura 4. Representação esquemática da região 11 p15.5 com as ICRs e genes regulados por imprinting genômico. As setas indicam o sentido da transcrição. P (cromossomo paterno) e M (cromossomo materno). Escala em megabases. 
A confirmação diagnóstica da DUP e da proporção de células alteradas é estabelecida confrontando-se o perfil genético dos pais com o do probando, geralmente utilizando-se a genotipagem de marcadores microssatélites, também conhecidos como sequências curtas repetidas em tandem (STR, do inglês, Short Tandem Repeats). Na maioria dos casos, a genotipagem é realizada pela reação em cadeia da polimerase, quantitativa fluorescente (ou QF-PCR, do inglês, Quantitative Fluorescent-Polymerase Chain Reaction) Nenhuma análise criteriosa tem sido realizada na escolha dos microssatélites para determinação de mosaicismo e DUP. Entre os marcadores utilizados para detectar DUP do cromossomo 11 (Dutly et al., 1998; Eggermann et al., 2005; Grati et al., 2007; Wilson et al., 2008; Bullman et al., 2008), 80\% é constituído por marcadores do tipo dinucleotídeos. O principal inconveniente da genotipagem de microssatélites dinucleotídeos é a ocorrência de produtos stutter, que são fragmentos menores gerados pelo deslizamento da enzima polimerase que difere em tamanho do alelo verdadeiro por múltiplas unidades de repetição e dificulta a designação alélica precisa (Shinde et al., 2003) (Figura 6). Outro problema na genotipagem de marcadores do tipo dinucleotídeo é a pronunciada amplificação preferencial do alelo menor em um locus heterozigoto quando comparado aos marcadores tetranucleotídeos e pentanucleotídeos. $\mathrm{Na}$ região 11 15.5, são oito os marcadores mais utilizados, sendo que destes apenas três (TH, D11S1318 e D11S4088) se encontram entre os genes regulados por imprinting pelas ICRs 1 e 2 (Tabela 1 ).

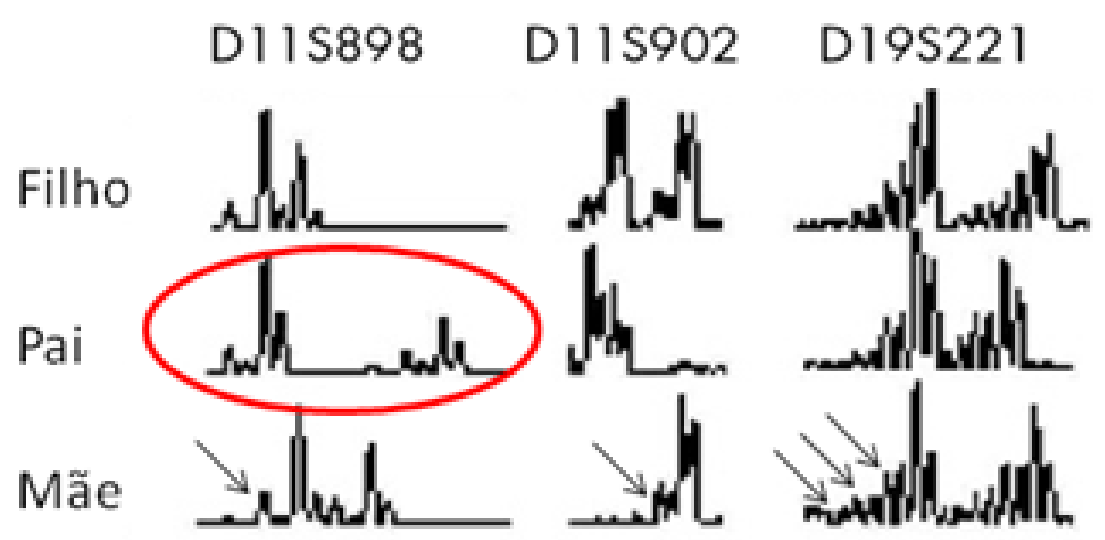

Figura 6. Perfil eletroforético de microssatélites dinucleotídeos. Os picos pequenos (indicados com as setas) que precedem os alelos verdadeiros representam produtos stutter tipicamente gerados pela amplificação de microssatélites dinucleotídeos. Note a amplificação preferencial do alelo da esquerda, para o marcador D11S898 (no cromossomo 11). Estes marcadores foram utilizados para determinação de mosaicismo global (Giurgea et al., 2006). 
Estudos epidemiológicos sugerem que crianças concebidas por tecnologias de reprodução assistida (TRA) possuem risco para SBW de aproximadamente $1 / 4000$, nove vezes maior do que para a população geral (Halliday et al., 2004). Em 95\% dos casos de SBW em crianças concebidas TRA, a hipometilação da ICR2 é encontrada (Wekesberg et al., 2010). Ainda não está claro, em humanos, se a perda materna de metilação observada em crianças concebidas por TRA é o resultado do procedimento em si ou a consequência da infertilidade ou de outros fatores de predisposição genética/ambiental em casais que realizam TRA (Choufani et al., 2010). Um estudo da ICR2 em crianças fenotipicamente normais concebidas por TRA mostrou alto índice de hipometilação para esta região, sugerindo uma vulnerabilidade do imprinting materno à TRA (Gomes et al., 2009).

A Hemihiperplasia Isolada $(\mathrm{HHI})$ é uma anormalidade que pode ser entendida como expressão parcial ou incompleta da SBW. Ela refere-se ao diagnóstico distinto evolvendo hipercrescimento assimétrico de um único ou múltiplos órgãos ou regiões do corpo e pode resultar de várias alterações genômicas incluindo alterações moleculares em 11 p15 (Gomes; Ramos, 2003; Shuman et al., 2006). A DUPpat Cr11 está presente em aproximadamente $16 \%$ dos pacientes com HHI (Shuman et al., 2006).

Há evidências de que algumas crianças com $\mathrm{HHI}$ estão sob o risco de desenvolverem o mesmo espectro de tumores que ocorre na SBW .O tumor de Wilms, um tipo de tumor renal, é o tumor mais comum entre os pacientes com SBW e HHI (Tan; Amor, 2006). 
Tabela1. Microssatélites descritos para a região 11p15.5. O motivo refere-se ao tipo de repetição, 2 (dinucleotídeo);4 (tetranucleotídeo).

\begin{tabular}{|c|c|c|c|c|c|c|c|c|c|c|c|c|c|c|c|c|c|c|c|c|c|c|c|c|c|c|c|c|}
\hline Marcador & Posição (pb) & Localização & Motivo & 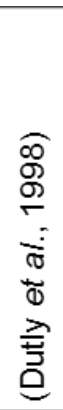 & 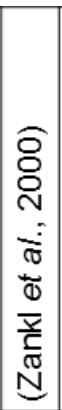 & 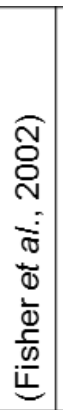 & 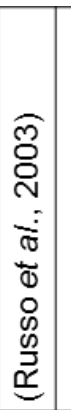 & 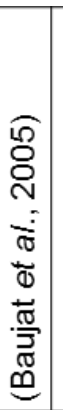 & 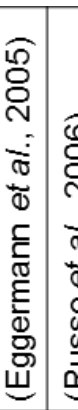 & 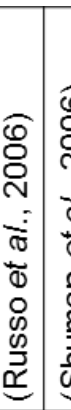 & 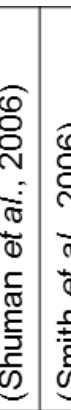 & 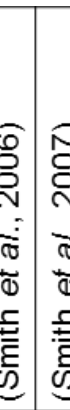 & 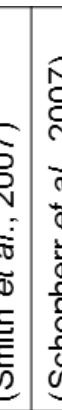 & 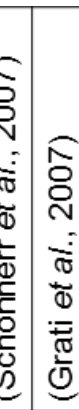 & 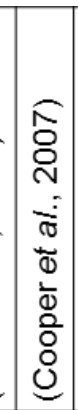 & 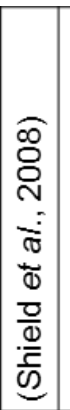 & 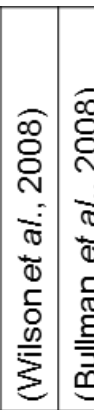 & 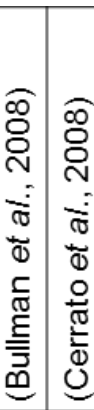 & 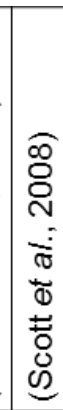 & 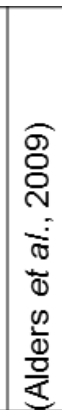 & 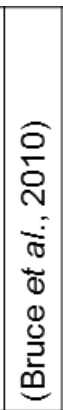 & 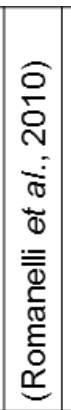 & 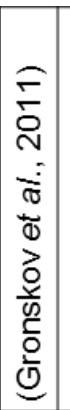 & 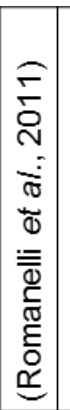 & 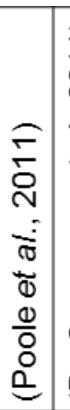 & 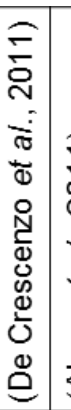 & 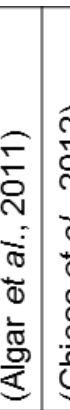 & \\
\hline D11S1363 & 1062153 & intergênico & 2 & & & & & & & & & & & & & & & & & & & & & & & & & \\
\hline D11S4177 & 1487260 & intergênico & 2 & & & & & & & & & & & & & & & & & & & & & & & & & \\
\hline D11S1984 & 1566873 & intergênico & 4 & & & & & & & & & & & & & & & & & & & & & & & & & \\
\hline D11S922 & 1605061 & intergênico & 2 & & & & & & & & & & & & & & & & & & & & & & & & & \\
\hline D11S4046 & 1963630 & intergênico & 2 & & & & & & & & & & & & & & & & & & & & & & & & & \\
\hline $\mathrm{TH}$ & 2192316 & $T H$ & 4 & & & & & & & & & & & & & & & & & & & & & & & & & \\
\hline D11S1318 & 2327223 & TSPAN32 & 2 & & & & & & & & & & & & & & & & & & & & & & & & & \\
\hline D11S4088 & 2755005 & KCNQ1 & 2 & & & & & & & & & & & & & & & & & & & & & & & & & \\
\hline
\end{tabular}




\subsection{Alterações (epi) genéticas na síndrome de Silver-Russell}

A síndrome Silver-Russell (SSR, OMIM \#180860) é uma doença heterogênea caracterizada por retardo severo do crescimento intrauterino, crescimento deficiente pós-natal, alterações craniofaciais (como frontal amplo, aparente macrocefalia e face triangular). Outras alterações menores auxiliam no diagnóstico e são frequentemente observadas como a clinodactilia do quinto dedo das mãos, hipotonia muscular, assimetria corporal, alterações dentárias, alterações nas orelhas e alterações nos dentes (Eggerman et al., 2010). A expressão fenotípica é alterada durante a infância e adolescência, geralmente tornando-se mais sutis com o avanço da idade (Eggerman, 2010).

DUPmat do cromossomo 7 (DUPmat Cr7) representa 10\% dos casos de SSR e muitos genes candidatos a agente etiológico desta doença neste cromossomo têm sido investigados (Eggerman et al., 1997; Hannula et al., 2001; Reboul et al., 2006; Eggerman et al., 2008). Somente por achados clínicos, pacientes com DUPmat 7 não podem ser discriminados sem ambiguidade dos pacientes com outras alterações (Kotzot, 2008; Wakeling et al., 2010).

Alterações genéticas e epigenéticas envolvendo o grupo de genes imprinted em 11 p15 têm sido reconhecidas como causa da SSR, sendo atualmente o cromossomo 11 considerado um elemento chave na etiologia da SSR (Eggerman et al., 2005 ;Netchine et al., 2007; Schönherr et al., 2007; Abu-Amero et al., 2008 Bartholdi et al., 2009). A SSR está associada com alterações de natureza oposta às observadas na SBW, por exemplo, hipometilação (SSR) versus hipermetilação (SBW) da ICR1, e duplicação de 11 p15 materna (SSR) versus paterna (SBW) (Eggerman et al., 2010; Bonaldi et al., 2011). Aproximadamente 38\% dos pacientes apresenta hipometilação na ICR1, levando à supressão da expressão de IGF2 e à expressão bialélica de $H 19$ (Eggermann et al., 2010). Consistente com este padrão, o mosaicismo para células com isodissomia materna do cromossomo 11 é o oposto da isodissomia paterna em mosaico observada na SBW (Bullman et al., 2008).

Os casos de DUPmat7 completa podem ter surgido por resgate da dissomia a partir de embrião triploide, portanto, é possível que haja um mosaicismo críptico com células triploides que contribui para o fenótipo da SSR. Estudos envolvendo resgate da dissomia para alguns autossomos têm mostrado uma forte associação com a 
inativação preferencial (não ao acaso) do cromossomo $\mathrm{X}$ em tecidos diploides (Lau et al., 1997; Penaherrera et al., 2000). Em 2001, Sharp e colaboradores encontraram um aumento na inativação preferencial do cromossomo $X$ em pacientes com SSR comparada ao grupo controle (Sharp et al., 2001).Embora a maioria dos casos de SSR seja esporádica, há relatos de famílias com acometidos., Um padrão de herança ligado ao $X$ dominante foi proposto para algumas famílias. Um aumento significativo na inativação preferencial extrema (> 95\%) foi encontrado em mães de crianças com SSR comparado ao grupo controle, sugerindo a participação do cromossomo $X$ na etiologia da SSR.

Erros pós-zigóticos também são sugeridos para a SSR, em casos de DUPmat segmental para o cromossomo 7 (Eggerman et al., 2008b) .Tanto para a SSR quanto para a SBW outros loci fora das ICRs 1 e 2 podem sofrer alterações epigenéticas (Bliek et al., 2009; Azzi et al., 2009; Turner et al., 2010; Kannenberg et al., 2012). Yamazawa e colaboradores (2010) identificaram uma mulher com SSR com DUP para todos os cromossomos e, ao contrário do que ocorre na SBW, a DUP foi de origem materna, com aproximadamente $80 \%$ de células ginogenéticas.

Em 2009, foi validado pela primeira vez um método efetivo baseado em eletroforese capilar para uma deteç̧ão rápida e econômica DUPmat Cr7baseada em dois multiplexes fluorescentes com marcadores para o cromossomo 7, embora todos eles também sejam dinucleotídeos (Giardina et al., 2009). A técnica de digestão do DNA com enzima sensível à metilação associada à MLPA (ou MSMLPA, do inglês, Methylation-specific-Multiplex Ligation-dependent Probe Amplification,) tem sido considerada um método robusto para detecção de alterações (epi) genéticas em 11p15.5 (Scott et al., 2008; Priolo et al., 2008). 


\subsection{Justificativa}

As síndromes de Beckwith-Wiedemann e de Silver-Russell, bem como a Hemihiperplasia Isolada, são doenças raras causadas por alterações genéticas e epigenéticas nos cromossomos 7 (SSR) e 11 (SBW, HHI, SSR).

Foram observadas diferenças (epi) genéticas significativas na etiologia da SBW na população japonesa comparada às populações da América do Norte e Europa (Sasaki et al., 2007). Para a população brasileira, não há dados publicados em periódicos, sobre alterações (epi) genéticas na SBW, HHI e SSR, com exceção de um trabalho publicado pelo grupo em 2005 (Gomes et al., 2005), sobre alterações epigenéticas na ICR1 em um pequeno grupo de pacientes com SBW e $\mathrm{HHI}$.

A ocorrência, em um mesmo indivíduo, de DUP para mais de um cromossomo em mosaico é uma possibilidade não inteiramente explorada. DUP em mosaico para todos os cromossomos do genoma foi recentemente proposta e demonstrada como um novo e interessante mecanismo para a SBW. No entanto, poucos casos têm sido descritos, sendo, provavelmente, sub-diagnosticados (Kaiser-Rogers et al., 2006; Giurgea et al., 2006; Wilson et al., 2008; H'mida et al., 2008; Morales et al., 2009; Romanelli et al., 2010).

O mosaicismo para DUP é reconhecidamente de difícil detecção por métodos qualitativos como a eletroforese em gel de acrilamida e coloração com nitrato de prata, principalmente se o número de células com DUP for baixo. Portanto, se faz necessário o desenvolvimento de metodologias moleculares mais acuradas de diagnóstico diferencial quantitativo. Os marcadores microssatélites utilizados para detecção de DUP em 11 p15.5 são quase todos do tipo dinucleotídeos, os quais possuem características indesejáveis no ensaio quantitativo, e nenhuma busca de novos marcadores informativos tem sido realizada.

Para estudos quantitativos de metilação do DNA, geralmente são utilizadas duas ou mais técnicas diferentes para a confirmação dos dados, tornando os resultados mais robustos. Portanto, o desenvolvimento de novos métodos para quantificação da metilação do DNA é importante para aumentar as alternativas de análise deste mecanismo epigenético. 


\section{OBJETIVOS}

\subsection{Objetivo Geral}

Determinar e quantificar alterações (epi) genéticas na síndrome de BeckwithWiedemann (SBW), síndrome Silver-Russell (SSR) e Hemihiperplasia Isolada $(\mathrm{HHI})$.

\subsection{Objetivos específicos}

- Desenvolver e validar novos marcadores microssatélites nos cromossomos 7 e 11, para o diagnóstico de alterações estruturais e dissomia uniparental, em pacientes com SSR, SBW e HHI.

- Determinar a frequência e extensão de dissomia uniparental paterna do cromossomo 11 e de mosaicismo global em indivíduos com SBW, HHI e DMP.

- Determinar a frequência de dissomia uniparental materna dos cromossomos 7 e 11 em indivíduos com SSR.

- Verificar o perfil de metilação nas regiões controladoras de imprinting ICR1 e ICR2 por MS-MLPA em pacientes com SSR, SBW e HHI.

- Verificar o perfil de metilação nas regiões controladoras de imprinting ICR1 e ICR2 por digestão enzimática sensível à metilação (DESM) associada à PCR em tempo real em pacientes com SSR, SBW e HHI.

- Desenvolver um novo ensaio baseado em DESM associada à QF-PCR para determinar o perfil de metilação nas ICRs 1 e 2.

- Determinar a informatividade de SNPs mapeados nos genes H19, IGF2 e KCNQ1OT1 por minissequenciamento quantitativo. 
CASUÍSTICA, MATERIAL E MÉTODOS 


\section{CASUÍSTICA, MATERIAL E MÉTODOS}

\subsection{Aspectos éticos}

Este trabalho faz parte de dois projetos aprovados pelo comitê de ética do Hospital das Clínicas da Faculdade de Medicina de Ribeirão Preto - USP e pelo Comitê Nacional de Ética em Pesquisa (CONEP) (Processos HCRP n 1497/2008, CONEP n²5000.057236/2003-08, CONEP n²5000.003012/00) (Anexos). Todas as coletas de material dos pacientes e de seus pais foram realizadas perante assinatura de Termo de Consentimento Livre e Esclarecido. As coletas foram efetuadas por profissionais autorizados no Ambulatório de Aconselhamento Genético do Hospital das Clínicas da Faculdade de Medicina de Ribeirão Preto Universidade de São Paulo (HC-FMRP-USP) ou encaminhadas por especialistas ao HC-FMRP-USP.

\subsection{Casuística}

A amostra foi selecionada a partir de pacientes atendidos pela equipe médica do Ambulatório de Aconselhamento Genético do Hospital das Clínicas da Faculdade de Medicina de Ribeirão Preto - Universidade de São Paulo (HC-FMRPUSP) ou remetidas por especialistas que referenciaram o grupo para o diagnóstico molecular.

Foram selecionados 32 pacientes com síndrome de Beckwith-Wiedemann (SBW), 16 com Hemihiperplasia Isolada (HHI) e 17 com síndrome de Silver-Russell (SSR). Os pais e irmão dos probandos foram avaliados quando disponíveis.

Além dos pacientes acima outros pacientes foram incluídos:três irmãos com SSR (SSR 1312, SSR 1312irmã e SSR 1312 irmão) devido a uma duplicação materna (Bonaldi et al., 2011), atendidos no Hospital das Clínicas da Faculdade de Medicina da USP de São Paulo (amostras gentilmente cedidas pela Dra Chong Ae Kim).;um indivíduo com hemihiperplasia e macroglossia ; um paciente DMP com cariótipo 46,XX/46,XY; além de sete indivíduos controles voluntários saudáveis. A tabela 2 mostra os indivíduos incluídos na pesquisa. 
Tabela 2. Pacientes investigados neste trabalho.

\begin{tabular}{|c|c|c|c|c|}
\hline Doença & Código (lab) & Sexo & Mãe & Pai \\
\hline SBW & 48 & $\mathrm{M}$ & $\mathrm{X}$ & $\mathrm{X}$ \\
\hline SBW & 80 & $\mathrm{~F}$ & $\mathrm{X}$ & $\mathrm{X}$ \\
\hline SBW & 129 & $\mathrm{M}$ & $\mathrm{X}$ & $\mathrm{X}$ \\
\hline SBW & 130 & $\mathrm{M}$ & $\mathrm{X}$ & $\mathrm{X}$ \\
\hline SBW & 131 & $\mathrm{M}$ & $\mathrm{X}$ & $\mathrm{X}$ \\
\hline SBW & 136 & $\mathrm{~F}$ & $\mathrm{X}$ & $\mathrm{X}$ \\
\hline SBW & 160 & $\mathrm{M}$ & $\mathrm{X}$ & $\mathrm{X}$ \\
\hline SBW & 170 & $\mathrm{~F}$ & & \\
\hline SBW & 171 & $\mathrm{M}$ & $\mathrm{X}$ & $\mathrm{X}$ \\
\hline SBW & 174 & $\mathrm{M}$ & $\mathrm{X}$ & \\
\hline SBW & 175 & $\mathrm{M}$ & $\mathrm{X}$ & $\mathrm{X}$ \\
\hline SBW & 212 & $\mathrm{~F}$ & $\mathrm{X}$ & $\mathrm{X}$ \\
\hline SBW & 213 & $\mathrm{M}$ & $\mathrm{X}$ & $\mathrm{X}$ \\
\hline SBW & 228 & $\mathrm{M}$ & $\mathrm{X}$ & $\mathrm{X}$ \\
\hline SBW & 626 & $\mathrm{M}$ & $\mathrm{X}$ & $\mathrm{X}$ \\
\hline SBW & 628 & $\mathrm{M}$ & $\mathrm{X}$ & \\
\hline SBW & 629 & $\mathrm{M}$ & & \\
\hline SBW & 630 & $\mathrm{~F}$ & $\mathrm{X}$ & $\mathrm{X}$ \\
\hline SBW & 744 & $\mathrm{~F}$ & $\mathrm{X}$ & $\mathrm{X}$ \\
\hline SBW & 745 & $\mathrm{M}$ & $\mathrm{X}$ & $\mathrm{X}$ \\
\hline SBW & 746 & $\mathrm{M}$ & & \\
\hline SBW & 1010 & $\mathrm{M}$ & & \\
\hline SBW & 1011 & $\mathrm{M}$ & & \\
\hline SBW & 1012 & $\mathrm{M}$ & $\mathrm{X}$ & \\
\hline SBW & 1013 & $\mathrm{~F}$ & $\mathrm{X}$ & $\mathrm{X}$ \\
\hline SBW & 1015 & $\mathrm{M}$ & & \\
\hline SBW & 1307 & $\mathrm{~F}$ & & \\
\hline SBW & 1313 & $\mathrm{M}$ & $\mathrm{X}$ & $\mathrm{X}$ \\
\hline SBW & 1351 & $\mathrm{~F}$ & & \\
\hline SBW & 1507 & $\mathrm{M}$ & & \\
\hline SBW & 1601 & $\mathrm{M}$ & $\mathrm{X}$ & $\mathrm{X}$ \\
\hline SBW & 1613 & $\mathrm{M}$ & $\mathrm{X}$ & $\mathrm{X}$ \\
\hline & & & & \\
\hline HHI & 33 & $\mathrm{~F}$ & $\mathrm{X}$ & $\mathrm{X}$ \\
\hline HHI & 101 & $\mathrm{~F}$ & $\mathrm{X}$ & $\mathrm{X}$ \\
\hline HHI & 132 & $\mathrm{M}$ & $\mathrm{X}$ & \\
\hline HHI & 134 & $\mathrm{~F}$ & $\mathrm{X}$ & $\mathrm{X}$ \\
\hline HHI & 209 & $\mathrm{M}$ & $\mathrm{X}$ & $\mathrm{X}$ \\
\hline & & & & \\
\hline
\end{tabular}




\begin{tabular}{|c|c|c|c|c|}
\hline \multicolumn{5}{|c|}{ Continuação tabela 2.} \\
\hline $\mathrm{HHI}$ & 210 & $\mathrm{~F}$ & & \\
\hline $\mathrm{HHI}$ & 211 & $\mathrm{M}$ & $\mathrm{x}$ & $\mathrm{X}$ \\
\hline $\mathrm{HHI}$ & 400 & $\mathrm{~F}$ & & \\
\hline $\mathrm{HHI}$ & 402 & $\mathrm{~F}$ & $\mathrm{x}$ & $\mathrm{X}$ \\
\hline $\mathrm{HHI}$ & 627 & $\mathrm{M}$ & $\mathrm{X}$ & $\mathrm{x}$ \\
\hline $\mathrm{HHI}$ & 747 & $\mathrm{M}$ & & \\
\hline $\mathrm{HHI}$ & 1109 & $\mathrm{M}$ & & \\
\hline $\mathrm{HHI}$ & 1532 & $\mathrm{~F}$ & & \\
\hline $\mathrm{HHI}$ & 1622 & $\mathrm{~F}$ & & \\
\hline $\mathrm{HHI}$ & 1635 & M & & \\
\hline $\mathrm{HHI}$ & 1642 & $\mathrm{M}$ & & \\
\hline $\mathrm{HH}+$ Macroglossia & 1551 & $\mathrm{M}$ & $\mathrm{x}$ & $\mathrm{X}$ \\
\hline SSR & 1003 & $\mathrm{M}$ & $\mathrm{X}$ & $\mathrm{x}$ \\
\hline SSR & 1006 & $\mathrm{M}$ & & \\
\hline SSR & 1007 & $\mathrm{M}$ & & \\
\hline SSR & 1108 & $\mathrm{~F}$ & & \\
\hline SSR & 1312 & $\mathrm{M}$ & $\mathrm{x}$ & \\
\hline SSR & 1312 irmã & $\mathrm{F}$ & & \\
\hline SSR & 1312 irmão & $\mathrm{M}$ & & \\
\hline SSR & 1356 & $\mathrm{~F}$ & $\mathrm{x}$ & $\mathrm{X}$ \\
\hline SSR & 1368 & $\mathrm{M}$ & $\mathrm{x}$ & \\
\hline SSR & 1374 & $\mathrm{~F}$ & & \\
\hline SSR & 1376 & $\mathrm{M}$ & & \\
\hline SSR & 1377 & $\mathrm{~F}$ & & \\
\hline SSR & 1378 & $\mathrm{M}$ & & \\
\hline SSR & 1379 & $\mathrm{M}$ & & \\
\hline SSR & 1380 & $\mathrm{M}$ & & \\
\hline SSR & 1381 & $\mathrm{M}$ & & \\
\hline SSR & 1382 & $\mathrm{~F}$ & & \\
\hline SSR & 1397 & $\mathrm{~F}$ & & \\
\hline SSR & 1525 & $\mathrm{M}$ & & \\
\hline SSR & 1529 & $\mathrm{~F}$ & & \\
\hline DMP & $0627220 \mathrm{G}$ & $\mathrm{M}$ & $\mathrm{X}$ & $\mathrm{x}$ \\
\hline
\end{tabular}

A presença dos pais, é indicada com um $X$ nas colunas 4 e 5 . Lab=código interno do laboratório; $\mathrm{M}=$ masculino; $\mathrm{F}=$ feminino; $\mathrm{SBW}=$ síndrome de Beckwith-Wiedemann; $\mathrm{HHI}=$ hemihiperplasia isolada; $\mathrm{HH}=$ hemihiperplasia; $\mathrm{SSR}=$ síndrome de Silver-Russell; $\mathrm{DMP}=$ displasia mesenquimal placentária. 


\subsection{Mineração de microsatélites nos cromossomos 7 e 11}

Os cromossomos 7 e 11 referência disponíveis no Centro Nacional de Informação Biotecnológica dos EUA (National Center for Biotechnology InformationNCBI), com os números de acesso NC_000011.9, AC_000054.1 e AC_000143.1 para o cromossomo 11, e NC_000007.13, AC_000054.1, AC_000139.1 para o cromossomo 7, tiveram suas sequências de nucleotídeos varridas em busca de marcadores microssatélites do tipo tetranucleotídeos e pentanucleotídeos, utilizando o programa Tandem Repeat Finder TRF (Benson, 1999). Este software utiliza um algoritmo capaz de encontrar os elementos repetitivos pelo percentual de identidade e pela frequência de indels (inserções/deleções) comparados a uma sequência referência com repetições perfeitas em série.

Quanto maior for o número de repetições e o tipo de repetição, maior a pontuação final. Por exemplo: 10 repetições perfeitas de tetranucleotídeos apresentam pontuação igual a 80 , enquanto 10 de dinucleotídeos apresentam pontuação 40 . Vinte repetições dinucleotídicas perfazem 80 pontos. As sequências imperfeitas possuem pontuação menor do que as perfeitas com o mesmo número de repetições, por exemplo: a sequência [AC AC AC AI AC AC AC AC] possui pontuação menor do que a sequência [AC AC AC AC AC AC AC AC]. Os descontos na pontuação final dependem da proporção dos erros de pareamento com uma sequência perfeita. Os parâmetros de busca das repetições [ $(2,3,5),(2,5,5),(2,5,7)$, $(2,7,7)]$ também influenciam na pontuação final. O primeiro valor fixo (2) corresponde à identidade e o segundo e terceiro valores ( 3 ou 5 ou 7 ) às imperfeições. $O$ parâmetro que desconta o menor valor da pontuação final devido às imperfeições é o $(2,3,5)$; portanto, o mais permissivo. Por outro lado, o $(2,7,7)$ é o mais restritivo. No presente trabalho foi utilizado o parâmetro mais restritivo.

Este programa foi utilizado pelo consórcio internacional de sequenciamento do genoma humano, que concluiu que repetições de 1-6 nucleotídeos constituem $1,5 \%$ do genoma humano e este valor pode aumentar para 3,9\% utilizando outros parâmetros (Leclercq et al., 2007). 


\subsection{Critérios de seleção para loci potencialmente polimórficos}

A natureza polimórfica dos marcadores tetra- e pentanucleotídeos foi validada utilizando-se o banco de dados dos três genomas-referência de cada cromossomo. As sequências foram alinhadas para cada microssatélite utilizando-se o programa online Multiple Sequence Alignment CLUSTALW (Kyoto University Bioinformatics Center) para identificar variantes alélicas. Todos os loci foram qualificados em uma escala de polimorfismo in silico variando de 1 (um alelo) a 3 (três alelos). Para a seleção de novos marcadores potencialmente polimórficos, foram avaliados microssatélites com pontuação mínima de 60 e identidade mínima de 90\% nos cromossomos 7 (NC_000007.13) e 11 (NC_000011.9).

\subsection{Construção de primers}

Para a contrução de primers ao redor das sequências repetitivas, foram utilizados os programas livres e online OligoPerfect ${ }^{\mathrm{TM}}$ Designer da Invitrogen ${ }^{\mathrm{TM}}$ (INVITROGEN) e o OligoCalc - Oligonucleotide Properties Calculator (Kibbe,2007). Os primers desenhados possuem 18-22 nucleotídeos e amplificam produtos in silico entre 100 e 450pb. Para análise em eletroforese capilar, foi inserido um dos seguintes fluorocromos em um primer de cada par: 6-FAM (azul), VIC (verde), PET (vermelho) e NED (amarelo). Para um melhor contraste, o fluorocromo NED está representado em preto nos eletroferogramas.

\subsection{Construção de um mapa genético para os cromossomos 7 e 11}

Para construção do mapa genético, foram utilizadas as informações do mapa combinado físico e de ligação do genoma humano (Rutgers Map) (Matise et al., 2007), também disponível online. Neste mapa estão presentes informações de marcadores do tipo SNPs, STRs e RFLPs (Random Fragment Length Polymorphism). A posição genética para múltiplos marcadores que não estão presentes no mapa pode ser estabelecida por interpolação das distâncias genéticas conhecidas. 


\subsection{Coleta de Sangue Periférico}

Para a análise molecular foram coletados $5-10 \mathrm{~mL}$ de sangue periférico de cada paciente em tubo à vácuo contendo o anticoagulante EDTA.

\subsection{Extração de DNA}

Amostras de DNA foram extraídas utilizando-se o método de extração e precipitação em $\mathrm{NaCl}$ (Olerup;Zetterquist, 1992, modificado). Ao volume de 0,5mL de sangue foi adicionado $1,0 \mathrm{~mL}$ de Tampão de Lise [Sacarose 0,32M; Tris HCl $12 \mathrm{mM}$ (pH 7,5); MgCl2 5,0M; Triton X 1,0\%] em microtubos de 1,5mL. As amostras foram centrifugadas à 13000rpm por 20segundos, o sobrenadante descartado e o procedimento repetido até a obtenção de pellet branco. O pellet foi ressuspendido em 80 $\mu \mathrm{L}$ de Tampão de Proteinase K (5X) [ $\mathrm{NaCl} 0,375 \mathrm{M}$; EDTA ( pH8,0) 0,12 M], $8,0 \mu \mathrm{L}$ de proteinase $\mathrm{K}(20 \mathrm{ng} / \mathrm{mL}), 10 \mu \mathrm{L}$ de SDS $20 \%$ e $283,3 \mu \mathrm{L}$ de água destilada e incubado à $55^{\circ} \mathrm{C}$ por 16 horas. Foram adicionados $120 \mu \mathrm{L}$ de $\mathrm{NaCl} 5 \mathrm{M}$ e, após agitação por 15 segundos, a amostra foi centrifugada a 13000rpm por 8 minutos. $O$ sobrenadante foi transferido para outro microtubo onde foi adicionado $1,0 \mathrm{~mL}$ de etanol à $20^{\circ} \mathrm{C}$, homogeneizado e centrifugado por 10 minutos à $13000 \mathrm{rpm}$ a uma temperatura de $4^{\circ} \mathrm{C}$. O sobrenadante foi descartado e o pellet restante desidratado. O pellet foi ressuspenso em $50 \mu \mathrm{L}$ de água deionizada.

\subsection{QF-PCR dos novos marcadores microssatélites}

Uma alíquota de $25-50 \mathrm{ng}$ de DNA total foi submetida ao processo de amplificação pelo método da PCR Quantitativa Fluorescente (QF-PCR) utilizando os primers listados (Tabela 11: Resultados) para os novos microssatélites selecionados. Os estágios da PCR foram: 1) um ciclo de 95ํㅡ por 11 minutos; 2) 29 ciclos a $94^{\circ} \mathrm{C}$ por 1 minuto, $57^{\circ} \mathrm{C}$ por 1 minuto, $72^{\circ} \mathrm{C}$ por 1 minuto; 3) um ciclo a $60^{\circ} \mathrm{C}$ por 60 minutos. Foram utilizados os termocicladores GeneAmp 9700 (Applied Biosystems) e T100'M Thermal Cycler (BIO-RAD). O volume final da reação foi de $25 \mu \mathrm{L}$ contendo: 2,5 $\mathrm{L}$ de tampão $10 \times(100 \mathrm{mM}$ Tris- $\mathrm{HCl}, 500 \mathrm{mM} \mathrm{KCl}, \mathrm{pH} 8,3) ; 1,5 \mathrm{mM}$ de $\mathrm{MgCl}_{2} ; 0,4 \mu \mathrm{M}$ de primers; 0,2mM de dNTPs; $1 \mathrm{U}$ Taq Polimerase (Invitrogen). A 
enzima AmpliTaq Gold (Applied Biosystems) foi utilizada para os marcadores D11S2255058 e D11S2589503.

\subsection{Caracterização dos alelos amplificados}

Aos produtos de amplificação foram adicionados formamida (Hi-Di Formamida, Applied Biosystems) e o padrão de massa molecular GeneScan LIZ 500, marcado com o fluorocromo LIZ ${ }^{T M}$ (fluorescência laranja) (Applied Biosystems). Os produtos de amplificação foram separados por eletroforese capilar com o polímero POP 4 (Applied Biosystems), utilizando a plataforma $\mathrm{ABI}$ Prism $^{\mathrm{TM}}$ 310 Genetic Analyzer. Os perfis eletroforéticos foram analisados utilizando os programas GeneScan ${ }^{\mathrm{TM}}$ e Genotyper ${ }^{\mathrm{TM}}$ (Applied Biosystems). Os alelos foram nomeados com o valor em pares de nucleotídeos dos produtos da PCR. A figura 7 mostra as informações de um eletroferograma.

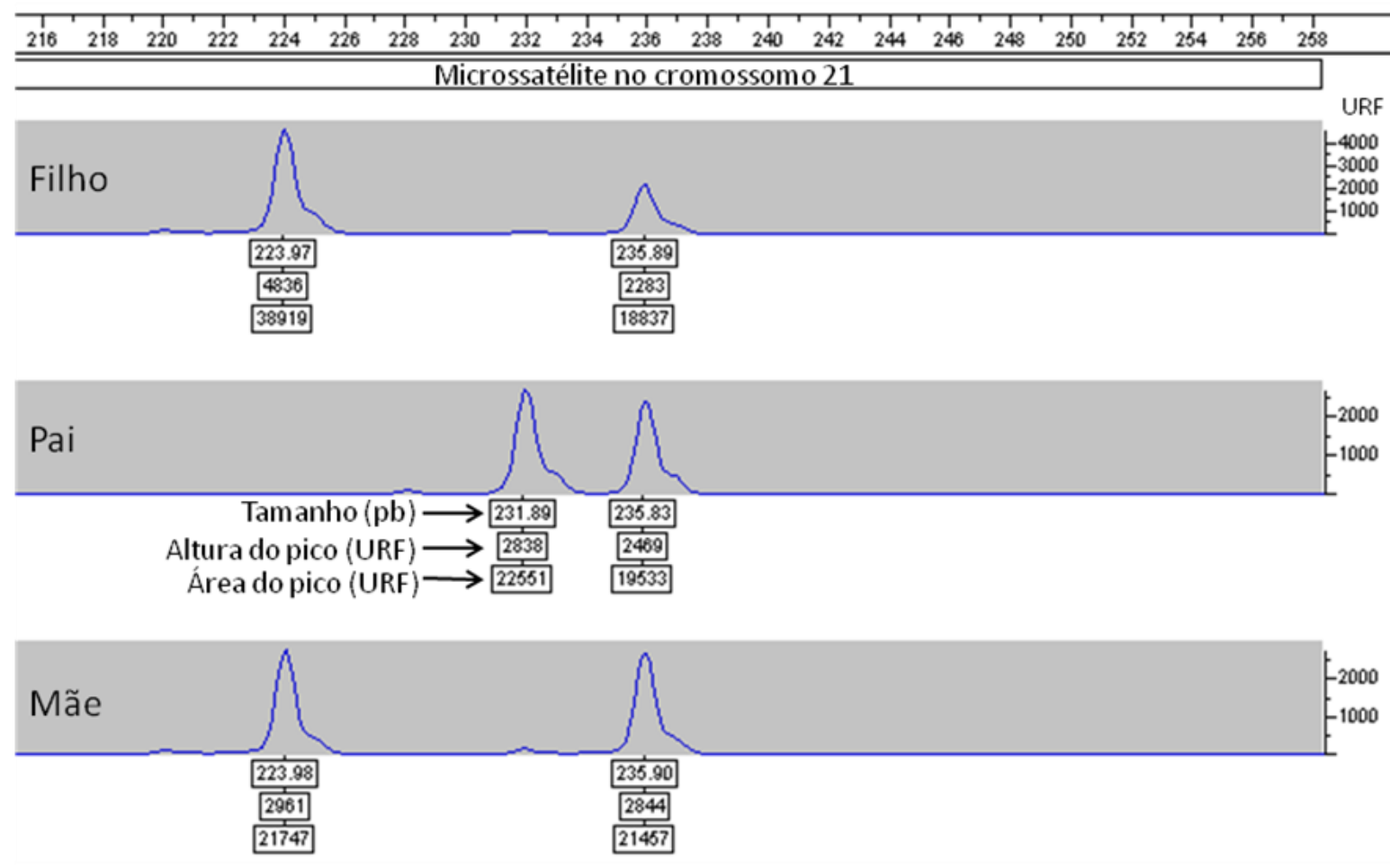

Figura 7. Representação um eletroferograma: Perfil genético obtido pela PCR Quantitativa Fluorescente (QF-PCR) em eletroforese capilar de um microssatélite no cromossomo 21 . Na parte superior, os números correspondem ao tamanho em pares de bases $(\mathrm{pb})$ do produto de amplificação (PA). Os picos representam os alelos amplificados, abaixo deles estão representados $O P A$ em tamanho $(\mathrm{pb})$, a altura e a área em unidades relativas de fluorescência (URF). Note a razão de aproximadamente 1:1 entre altura ou área dos picos para o pai e para a mãe. No filho, portador da síndrome de Down, a razão é de aproximadamente 2:1 indicando duas cópias do alelo 224pb (números arredondados). Neste trabalho, foi considerada a área do pico para cálculos quantitativos. 


\subsection{Marcadores para análise de dissomia uniparental global}

Os casos que apresentaram dissomia uniparental em 11p15.5 foram genotipados com os marcadores do kit AmpFISTR ${ }^{\circledR}$ Identifiler ${ }^{\circledR}$ (Applied Biosystems). No ensaio foram genotipados, em tubo único, 15 marcadores microssatélites em 13 autossomos (Tabela 3). Marcadores extras nos cromossomos X (Ogilvie et al., 2005), 13, 18 e 21 (Hultén et al., 2003) foram genotipados no caso positivo para dissomia uniparental global (Tabela 4). A genotipagem foi como descrita acima para os novos microssatélites.

Tabela 3: Marcadores microssatélites do kit AmpFISTR® Identifiler® .

\begin{tabular}{ll}
\hline Marcador & Localização \\
\hline TPOX & 2p25.3 \\
D2S1338 & 2q35 \\
D3S1358 & $3 p 21.31$ \\
FGA & $4 q 31.3$ \\
D5S818 & $5 q 23.2$ \\
CSF1PO & $5 q 32$ \\
D7S820 & $7 q 21.11$ \\
D8S1179 & $8 q 24.13$ \\
TH01 & $11 p 15.5$ \\
VWA & $12 p 13.31$ \\
D13S317 & $13 q 31.1$ \\
D16S539 & $16 q 24.1$ \\
D18S51 & $18 q 21.33$ \\
D19S433 & $19 q 12$ \\
D21S11 & 21q21.1 \\
\hline
\end{tabular}


Tabela 4: Marcadores extras, para verificação de dissomia uniparental global.

\begin{tabular}{ll}
\hline Marcador & Localização \\
\hline D13S742 & $13 q 12.12$ \\
D13S252 & $13 q 12.2$ \\
D13S305 & $13 q 13.3$ \\
D13S634 & $13 q 21.33$ \\
D13S628 & $13 q 31.1$ \\
D13S762 & $13 q 31.3$ \\
D18S391 & $18 p 11.31$ \\
D18S1002 & $18 q 11.2$ \\
D18S535 & $18 q 12.3$ \\
D18S978 & $18 q 12.3$ \\
D18S499 & $18 q 21.32$ \\
D18S386 & $18 q 22.1$ \\
D21S2039 & $21 q 22.11$ \\
D21S1411 & $21 q 22.3$ \\
DXS996 & Xp22.3 \\
DXS1283E & Xp22.3 \\
DXS981 & Xq13.1 \\
DXS1187 & Xq26.2 \\
HPRT & Xq26.3 \\
P39 & Xq28 \\
X22 & Xqter/Yqter \\
\hline
\end{tabular}




\subsection{Amplificação de múltiplas sondas dependente de ligação-metilação específica MS-MLPA}

Para o ensaio de MS-MLPA (Methylation-Specific Multiplex Ligation-dependent Probe Amplification) foi utilizado o kit ME030-C1 (MRC Holland). O kit contém 26 sondas específicas para a região 11 p15 SBW/SSR, sendo que 11 contêm um sítio de reconhecimento da enzima Hhal, fornecendo informações sobre o nível de metilação da sequência alvo. Além da detecção de metilação aberrante, as 26 sondas geram informações sobre alterações no número de cópias na amostra analisada. Duas sondas são incluídas no gene NSD1 que está associado com a síndrome de Sotos, uma doença que compartilha um fenótipo similar à SBW, e 13 sondas fora da região SBW/SSR servem como referência. Uma sonda de controle de digestão está incluída para confirmar a digestão completa pela enzima Hhal. A tabela 5 mostra as especificações das sondas presentes no kit. As sondas foram renomeadas, sendo que as presentes na região 11 p15.5 foram nomeadas segundo a posição física da sonda no cromossomo referência NC_000011.9. As sondas controle foram nomeadas segundo sua localização citogenética.

Diferentemente da PCR multiplex convencional, a MS-MLPA utiliza um único par de primers para todas as sondas, tornando o método mais robusto. Um primer é marcado com o fluorocromo FAM e o produto é visualizado por eletroforese capilar. Cada sonda consiste de dois oligonucleotídeos que hibridam adjacentes no DNA alvo e posteriormente se ligam. Os oligonucleotídeos possuem sítios de pareamento dos primers e uma sequência de nucleotídeos única para cada sonda denominada sequência stuffer, que não se hibrida ao DNA alvo e permite a geração de amplicons de diferentes tamanhos. Na técnica de MS-MLPA não é o DNA da amostra que é amplificado durante a PCR, mas sim as sondas hibridadas no DNA da amostra. A análise consiste em duas partes: (1) determinar número de cópias comparando diferentes amostras não digeridas e (2) determinar padrões de metilação comparando cada amostra não digerida a sua homóloga digerida.

O protocolo de MS-MLPA consistiu nas seguintes etapas:

1) Desnaturação: Uma alíquota de $3,5 \mu \mathrm{L}$ de DNA (50ng/ $\mu \mathrm{L})$ foi desnaturada por 8 minutos a $98^{\circ} \mathrm{C}$ no termociclador (Veritiß 96-Well Thermal Cycler- Applied Biosystems). 
2) Hibridação: Ao DNA desnaturado foi adicionado $0,75 \mu \mathrm{L}$ da solução tampão de hibridação ( $\mathrm{KCl}$, Tris-HCl, EDTA e PEG-6000, pH 8,5) e 0,75 $\mu \mathrm{L}$ do mix de sondas (oligonucleotídeos sintéticos, Tris-HCl, EDTA, pH 8,0). A solução foi incubada no termociclador por uma hora a $95^{\circ} \mathrm{C}$ seguido de um passo de quatro horas a $60^{\circ} \mathrm{C}$.

3) Ligação e ligação/digestão: foi adicionado $1,5 \mu \mathrm{L}$ do tampão $A$ de ligação (NAD, pH 3,5) e $5 \mu \mathrm{L}$ de água ultrapura. A solução foi separada em dois tubos contendo $5,75 \mu \mathrm{L}$ cada. Em um tubo foi adicionado $0,75 \mu \mathrm{L}$ de tampão $\mathrm{B}$ de ligação (Tris- $\mathrm{HCl}$, detergentes não iônicos, $\mathrm{MgCl}_{2}, \mathrm{pH} 8,5$ ), $0,25 \mu \mathrm{L}$ da enzima ligase [Glicerol, BRIJ (0,05\%), EDTA, Beta-mercaptoetanol $(0,1 \%), \mathrm{KCl}$, Tris$\mathrm{HCl}$. pH 7,5, enzima Ligase-65] e 3,5 $\mu \mathrm{L}$ de água ultrapura. Em outro tubo, foram adicionados os mesmos reagentes, incluindo $0,5 \mu \mathrm{L}$ da enzima Hhal (20u/ $\mathrm{LL}$ New England Biolabs). O material foi incubado no termociclador por 30 minutos a $48{ }^{\circ} \mathrm{C}$ (para ligação e digestão), seguido por 5 minutos a $98{ }^{\circ} \mathrm{C}$ para inativação das enzimas.

4) Amplificação: ao volume total das misturas de ligação e ligação/digestão, foi adicionado $0,75 \mu \mathrm{L}$ de $\mathrm{PCR}$ primer mix [par de primers, dNTPs, Tris- $\mathrm{HCl}, \mathrm{KCl}$,

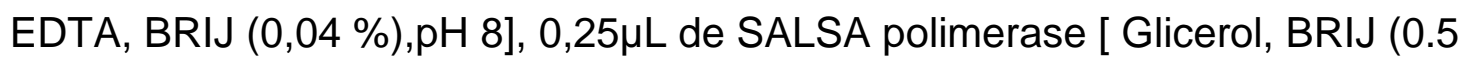
$\%$ ), EDTA, DTT (0,1\%), KCl, Tris-HCl, DNA polimerase, $\mathrm{pH} 7,5]$ e 1,0 $\mu \mathrm{L}$ de água ultrapura. Para amplificação, o produto foi submetido a 35 ciclos de $95^{\circ} \mathrm{C}$ por 30 segundos; $60^{\circ} \mathrm{C}$ por 30 segundos; $72^{\circ} \mathrm{C}$ por 30 segundos e extensão final a $72^{\circ} \mathrm{C}$ por 20 minutos. A figura 8 exibe o resumo das etapas do ensaio de MS-MLPA.

Para eletroforese capilar, $0,7 \mu \mathrm{L}$ do produto amplificado foi adicionado a uma solução contendo 9,1 $\mathrm{L}$ de formamida (Hi-Di Formamide, Applied Biosystems) e 0,2 $\mathrm{LL}$ do padrão de massa molecular GeneScan LIZ 500 (Applied Biosystems). O material foi submetido à eletroforese capilar com o polímero POP 6 (Applied Biosystems), utilizando-se a plataforma $A B I$ Prism $^{T M} 3130$ Genetic Analyzer. Os perfis eletroforéticos foram analisados utilizando-se os programas GeneMapper ${ }^{T M}$ (Applied Biosystems) e GeneMarker (Softgenetics ${ }^{\circledR}$ ). A normalização das sondas foi realizada com o programa Coffalyser (MRC-Holland). Após a normalização das sondas, a área relativa do pico entre 0,75 e 1,25 foi considerada como resultado sem alteração (duas cópias), área relativa acima de 1,25 foi considerada como 
duplicação ou abaixo de 0,75 , deleção. Para alterações estruturais, as razões foram estabelecidas para cada paciente, pela comparação com três controles hígidos. Para alterações epigenéticas, as razões foram estabelecidas pela comparação entre o material digerido e não digerido de cada paciente. Para sondas com sítio de restrição para enzima Hhal nas ICRs 1 e 2, foi considerado hipometilação para razões abaixo de 0,33, e hipermetilação para razões acima de 0,66.

Tabela 5. Características das sondas utilizadas no ensaio MS-MLPA.

\begin{tabular}{|c|c|c|c|c|c|}
\hline Sondas (nomeação neste trabalho) & Sondas (nomeação kit) & $\begin{array}{c}\text { Tamanho } \\
\text { (nt) }\end{array}$ & Posição & $\begin{array}{l}\text { Sítio } \\
\text { Hhal }\end{array}$ & $\begin{array}{c}\% \text { de } \\
\text { metilação } \\
\text { (sangue) }\end{array}$ \\
\hline H19 (éxon 5) 2016835 & H19 probe $16670-L 19241$ & 228 & $11 \mathrm{p} 15.5$ & & \\
\hline H19 (éxon 1)2019209 & H19 probe 14731-L01713 & 160 & $11 \mathrm{p} 15.5$ & & \\
\hline H19 (éxon 1)2019380** & H19 probe $06266-L 05772$ & 301 & $11 \mathrm{p} 15.5$ & Sim & $50 \%$ \\
\hline H19 (éxon 1)2019523** & H19 probe $14792-L 16503$ & 238 & $11 \mathrm{p} 15.5$ & $\operatorname{Sim}$ & $50 \%$ \\
\hline H19 (upstream) 2019691 ${ }^{\star \star}$ & H19 probe $14063-L 08764$ & 184 & $11 \mathrm{p} 15.5$ & $\operatorname{Sim}$ & $50 \%$ \\
\hline H19 (upstream) 2019992 ${ }^{\star \star}$ & H19 probe $08743-L 20532$ & 135 & $11 \mathrm{p} 15.5$ & $\operatorname{Sim}$ & $50 \%$ \\
\hline H19 (upstream) 2022320 & H19 probe $10588-L 11143$ & 454 & $11 \mathrm{p} 15.5$ & & \\
\hline H19 (upstream) 2022833 & H19 probe $10586-L 11141$ & 214 & $11 \mathrm{p} 15.5$ & & \\
\hline H19 (upstream) 2025813 & H19 probe 16671-L19242 & 190 & $11 \mathrm{p} 15.5$ & & \\
\hline IGF2 (éxon 7) 2154820 & IGF2 probe 06272-L05778 & 284 & $11 \mathrm{p} 15.5$ & & \\
\hline IGF2 (éxon 4) 2161019\# & IGF2 probe 06269-L20841 & 171 & $11 \mathrm{p} 15.5$ & Sim & Variável \\
\hline KCNQ1 (éxon 2) 2482860 & KCNQ1 probe 14732-L02903 & 436 & $11 \mathrm{p} 15.5$ & & \\
\hline KCNQ1 (éxon 3) 2548988 & KCNQ1 probe 14791-L16502 & 221 & $11 \mathrm{p} 15.5$ & & \\
\hline KCNQ1 (éxon 7) 2594093 & KCNQ1 probe 15055-L04802 & 328 & $11 \mathrm{p} 15.5$ & & \\
\hline KCNQ1 (éxon 8) 2604658 & KCNQ1 probe 16669-L19240 & 364 & $11 \mathrm{p} 15.5$ & & \\
\hline KCNQ1 (éxon 9) 2606444 & KCNQ1 probe 16655-L20510 & 400 & $11 \mathrm{p} 15.5$ & & \\
\hline KCNQ1 (íntron 11)-KCNQ10T1 2720540** & KCNQ1OT1 probe 16654-L19204 & 274 & $11 \mathrm{p} 15.5$ & Sim & $50 \%$ \\
\hline KCNQ1 (intron 11)-KCNQ1OT1 2720610** & KCNQ1OT1 probe 06276-L05782 & 166 & $11 \mathrm{p} 15.5$ & $\operatorname{Sim}$ & $50 \%$ \\
\hline KCNQ1 (íntron 11)-KCNQ1OT1 2721018** & KCNQ1OT1 probe 07172-L06781 & 393 & $11 \mathrm{p} 15.5$ & Sim & $50 \%$ \\
\hline KCNQ1 (íntron 11) $2721387^{\text {* }}$ & KCNQ1OT1 probe 07173-L19191 & 141 & $11 \mathrm{p} 15.5$ & $\operatorname{Sim}$ & $50 \%$ \\
\hline KCNQ1 (éxon 15) 2798205 & KCNQ1 probe 14793-L16504 & 373 & $11 \mathrm{p} 15.5$ & & \\
\hline KCNQ1 (éxon 17) 2869994 & KCNQ1 probe 03555-L21092 & 411 & $11 \mathrm{p} 15.5$ & & \\
\hline CDKN1C (éxon 3) 2905027 & CDKN1C probe 14734-L20842 & 445 & $11 \mathrm{p} 15.5$ & & \\
\hline CDKN1C (éxon 1) 2906657 & CDKN1C probe 06262-L05768 & 196 & $11 \mathrm{p} 15.5$ & & \\
\hline CDKN1C (éxon 1) 2906729\# & CDKN1C probe 15054-L18042 & 346 & $11 \mathrm{p} 15.5$ & $\operatorname{Sim}$ & Variável \\
\hline Controle da digestão\# & Digestion Control probe 09153-L09311 & 355 & $08 p 21$ & Sim & $0 \%$ \\
\hline NSD1 éxon 22 & NSD1 probe 17048-L02071 & 418 & $05 q 35.3$ & & \\
\hline NSD1 éxon 24 & NSD1 probe 16702-L02529 & 319 & $05 q 35.3$ & & \\
\hline Controle 2p25 & Reference probe 13471-L11729 & 463 & $02 p 25$ & & \\
\hline Controle 2q24 & Reference probe 04528-L03917 & 310 & $02 q 24$ & & \\
\hline Controle 3q29 & Reference probe 03262-L20515 & 292 & $03 q 29$ & & \\
\hline Controle 7q31 & Reference probe 02944-L02376 & 154 & $07 q 31$ & & \\
\hline Controle 9q21 & Reference probe 05725-L05164 & 178 & $09 q 21$ & & \\
\hline Controle 10q21 & Reference probe 00973-L18737 & 383 & $10 q 21$ & & \\
\hline Controle $10 q 25$ & Reference probe $11622-\mathrm{L} 12379$ & 129 & $10 q 25$ & & \\
\hline Controle $12 q 13$ & Reference probe 07404-L07051 & 208 & $12 q 13$ & & \\
\hline Controle $14 q 24$ & Reference probe 12415-L13416 & 148 & $14 q 24$ & & \\
\hline Controle $16 q 22$ & Reference probe 02416-L01862 & 337 & $16 q 22$ & & \\
\hline Controle 17p12 & Reference probe 01462-L00927 & 256 & $17 \mathrm{p} 12$ & & \\
\hline Controle 18q21 & Reference probe 07800-L07555 & 427 & $18 q 21$ & & \\
\hline Controle $22 \mathrm{q} 11$ & Reference probe 05927-L07395 & 202 & $22 \mathrm{q} 11$ & & \\
\hline
\end{tabular}



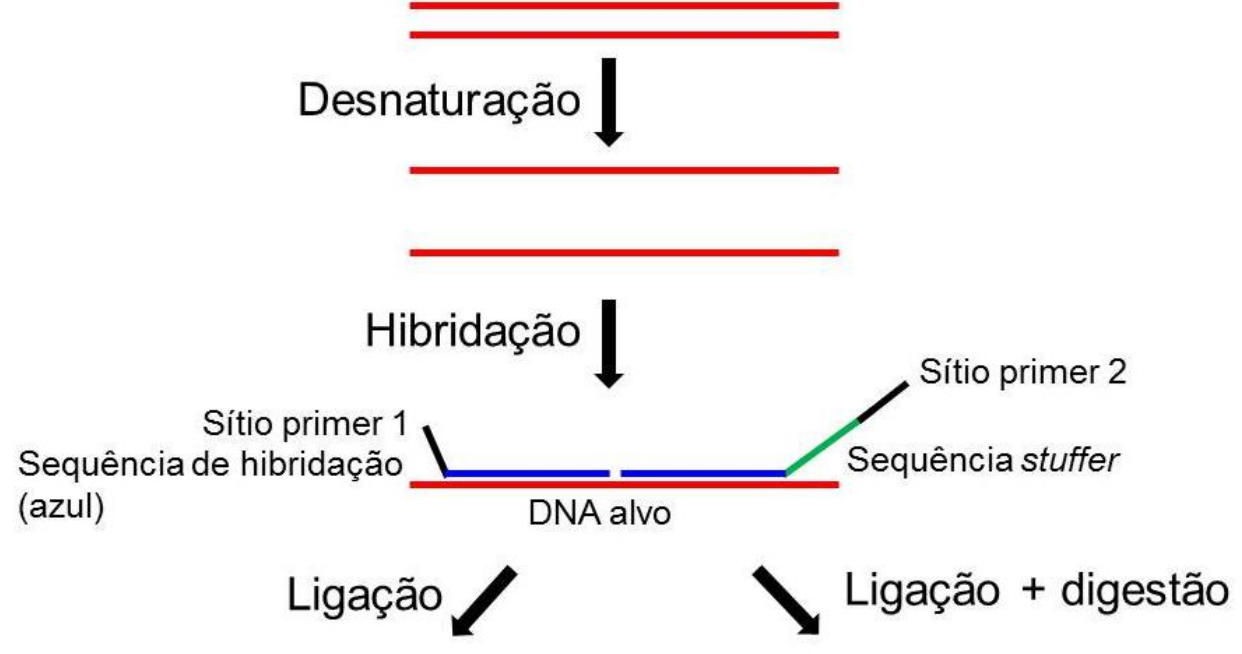
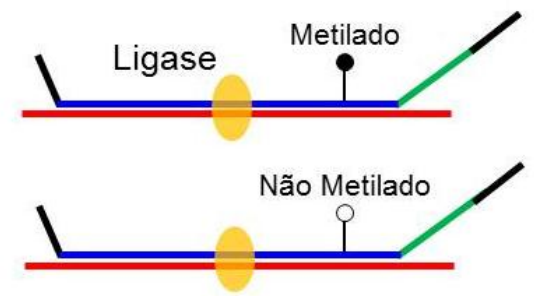

Amplificação
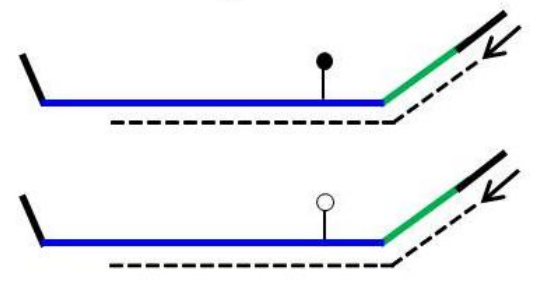

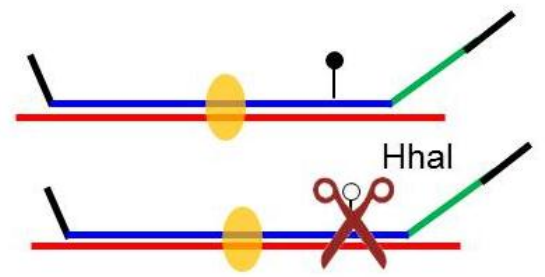

Amplificação

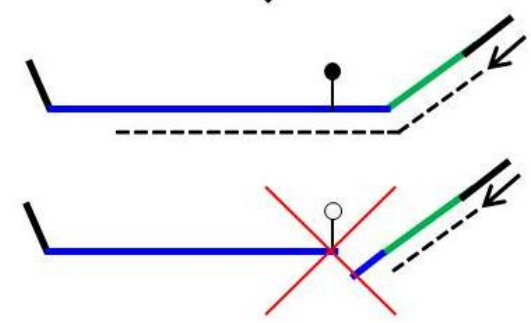

Figura 8. Resumo das etapas do ensaio MS-MLPA. 


\subsection{Digestão Enzimática Sensível à Metilação Associada à PCR em Tempo Real (DESM-RT)}

A análise da metilação das ICRs 1 e 2 pelo método DESM-RT desenvolvido pelo grupo (Gomes et al., 2007) consistiu de uma digestão do DNA anterior à PCR, pela enzima de restrição sensível à metilação Hpall, a qual reconhece e cliva o sítio CCGG, mas não atua quando a citosina interna encontra-se metilada. Dessa forma, a clivagem ocorreu somente no alelo não-metilado, impedindo sua amplificação pela PCR. A digestão com a enzima Hpall foi realizada utilizando-se 0,2 $\mu$ g de DNA em condição e concentração de tampão segundo recomendação do fabricante (Invitrogen) [20mM de Tris-HCL (pH 7,4), $10 \mathrm{mM} \mathrm{MgCl}$ ] a $37^{\circ} \mathrm{C}$ por 16 horas.

A quantificação do DNA metilado foi obtida pelo sistema $A B I S_{\text {StepOne }}{ }^{T M}$ em um volume total de reação de $25 \mu \mathrm{L}$ contendo SYBRGreen PCR Master Mix (Applied Biosystems) e primers na concentração de acordo com a tabela 6. A análise quantitativa da metilação foi obtida pela comparação entre a quantidade amplificada do DNA não digerido, com a do DNA digerido com Hpall. Ambas as amostras foram amplificadas por PCR em Tempo Real e o ciclo no qual o nível de fluorescência emitido pelas amostras amplificadas atingiu o nível de fluorescência arbitrário Ct (threshold) foi obtido para cada amostra pelo software ABI. Cada amostra foi analisada em triplicata e o valor médio do Ct foi obtido. De acordo com o princípio de amplificação exponencial das amostras (ou seja, o dobro de produto a cada ciclo) a porcentagem de DNA metilado foi calculada pela fórmula $(1 / 2) n$, sendo $n$ igual ao número de ciclos, obtido pela subtração da média do $\mathrm{Ct}$ do DNA não digerido $(\mathrm{Ct} H)$ pela média do Ct do DNA digerido (Ct D). Quando uma das amostras apresentava um valor com desvio padrão maior do que 0,17 , a mesma era excluída. 0 isoesquisômero (Mspl) da enzima Hpall foi utilizado como controle da digestão, pelo fato desta enzima não ser sensível à metilação e clivar o DNA metilado e não metilado, no mesmo sítio de restrição da Hpall. As condições de ciclagem da PCR para ICR 1 foram: $95^{\circ} \mathrm{C}$ por 10 minutos e 40 ciclos $\left(95^{\circ} \mathrm{C}\right.$ por 15 segundos e $61^{\circ} \mathrm{C}$ por 60 segundos), seguidos por análise de dissociação realizada de $60^{\circ} \mathrm{C}$ a $95^{\circ} \mathrm{C}$, variando $1^{\circ} \mathrm{C}$ a cada segundo. Para a ICR2 as condições foram: $95^{\circ} \mathrm{C}$ por 10 minutos e 40 ciclos $\left(95^{\circ} \mathrm{C}\right.$ por 15 segundos e $65,4^{\circ} \mathrm{C}$ por 45 segundos), seguido por análise de dissociação realizada de $60^{\circ} \mathrm{C}$ a $95^{\circ} \mathrm{C}$, variando $1^{\circ} \mathrm{C}$ a cada segundo. 
Tabela 6. Primers utilizados no ensaio DESM-RT.

\begin{tabular}{|l|l|l|l|l|}
\hline Primer & Forward & Reverse & Concentração & Amplicon \\
\hline KvDMR1 DESM-RT & GTGCCTCTCAGCGTGGTCC & AACCACGATGACTGACGCAC & $0,03 \mu \mathrm{M}$ & $96 \mathrm{bp}$ \\
\hline H19DMR & CAATGAGGTGTCCCAGTTCCA & CTATGAGTGTCCTATTCCCA & $0,12 \mu \mathrm{M}$ & $326 \mathrm{bp}$ \\
\hline
\end{tabular}

\subsection{Digestão Enzimática Sensível à Metilação Associada à PCR Quantitativa Fluorescente (DESM-QFPCR)}

Um ensaio baseado nos princípios da MS-MLPA, em menor escala, foi desenvolvido neste trabalho. O ensaio é composto primeiramente por um par de primers que abrange uma região controladora de imprinting, contendo um sítio de reconhecimento para enzimas sensíveis à metilação. Também é composto por um segundo par de primers (utilizado como controle negativo ou $\mathrm{CN}$ ), que ancoram fora da ICR e cujo amplicon não é digerido pela enzima Hpall. Foi desenvolvido um ensaio biplex (dois pares de primers amplificados no mesmo tubo na QFPCR) para a ICR1 e ICR2 (Tabela 7). Os primers forward foram marcados com o fluorocromo 6FAM. O DNA foi digerido como na DESM-RT, e a amplificação e a eletroforese foram realizadas com os mesmos parâmetros da genotipagem de microssatélites.

As áreas dos picos dos DNAs digerido e não-digerido foram comparadas e o fator de correção utilizado como descrito para quantificação de inativação do cromossomo X (Busque et al., 2009).

Tabela 7. Primers utilizados no ensaio DESM-QFPCR.

\begin{tabular}{|l|l|l|l|l|}
\hline Primer & Forward & Reverse & Concentração & Amplicon \\
\hline ICR1 & FAM-ATCCAGTTGACCGAGCTTGT & CAAAGGCCAAGGTGGTGA & $1,1 \mu \mathrm{M}$ & $288 \mathrm{bp}$ \\
\hline CN-ICR1 & FAM-TGCCTGCTGAGCACTGAC & GTGCTGTCCCCAGTGAGC & $0,2 \mu \mathrm{M}$ & $276 \mathrm{bp}$ \\
\hline ICR2 & FAM-GAGGACCACGCTGAGAGG & ACTCTTCGGCCAATGACAG & $0,6 \mu \mathrm{M}$ & $278 \mathrm{bp}$ \\
\hline CN-ICR2 & FAM-TCCATCACTTTCTAGCCATAGGA & CTGGATGCTGCCTCAAGC & $0,3 \mu \mathrm{M}$ & $284 \mathrm{bp}$ \\
\hline
\end{tabular}




\subsection{Minissequenciamento de SNPs por SNapShot}

Para genotipagem de SNPs foram selecionados quatro marcadores em três genes: H19 (rs2839704 T/C), IGF2 (rs680 A/G) e KCNQ1OT1 (rs760419 A/G e rs231357 A/G) Figura 9. Os critérios de seleção foram a alta taxa de heterozigose esperada e a presença do SNP no RNA. Os primers para os genes H19 e IGF2 foram previamente descritos (Tadokoro et al., 1991; Rainier et al., 1993), os primers para o gene KCNQ1OT1 e todos para minissequenciamento foram desenvolvidos neste trabalho. Os produtos de amplificação pela PCR (amplicons) foram visualizados em gel de agarose $2 \%$ corado com brometo de etídeo.

Para o minissequenciamento, foi utilizado o SNaPshot ${ }^{\mathrm{TM}}$ Multiplex Kit da Applied Biosystems. Este ensaio foi realizado após a purificação dos amplicons para remoção de dNTPs e primers, pelo AccuPrep® PCR Purification Kit (Bioneer). A tabela 8 mostra a sequência dos primers e o tamanho dos amplicons. Diferentemente do sequenciamento convencional, no minissequenciamento estão presentes apenas didesoxinucleotídeos (ddNTPs) para a DNA polimerase. Quando é inserido um único ddNTP a reação é terminada. O primer deve parear justaposto ao SNP que se deseja genotipar.

Tabela 8. Sequência de primers utilizados no minissequenciamento.

\begin{tabular}{|c|c|c|}
\hline Primer & Sequência & Amplicon (pb) \\
\hline IGF2-forward & CTTGGACTTTGAGTCAAATTGG & \multirow{2}{*}{236} \\
\hline IGF2-reverse & CCTCCTITGGTCTTACTGGG & \\
\hline IGF2-SNapShot & GTCCCTGAACCAGCAAAGAGAAAAGAAGG & 29 \\
\hline H19-forward & TACAACCACTGCACTACCTG & \multirow{2}{*}{656} \\
\hline H19-reverse & TGGAATGCTTGAAGGCTGCT & \\
\hline H19-SNapShot & GGCACTTGCCAAGGTGGCTCACACTCACGCACACTCG & 37 \\
\hline KCNQ1OT1a-forward & AGTAAGGAAGAGCCCAACACTG & \multirow{2}{*}{331} \\
\hline KCNQ10T1a -reverse & GATCATGTTCCCAGGCTCA & \\
\hline KCNQ1OT1a -SNapShot & TGAAGGGCTGGGCTGGAGGGGACTGG & 26 \\
\hline KCNQ1OT1b-forward & AGGCCTTTCCTTACTCCСTCT & \multirow{2}{*}{433} \\
\hline KCNQ10T1b -reverse & GGAAACGGTCCCCTTAAGAA & \\
\hline KCNQ1OT1b -SNapShot & CTCTGTGACACGTTTCATAGTCAGACAAAACC & 32 \\
\hline
\end{tabular}



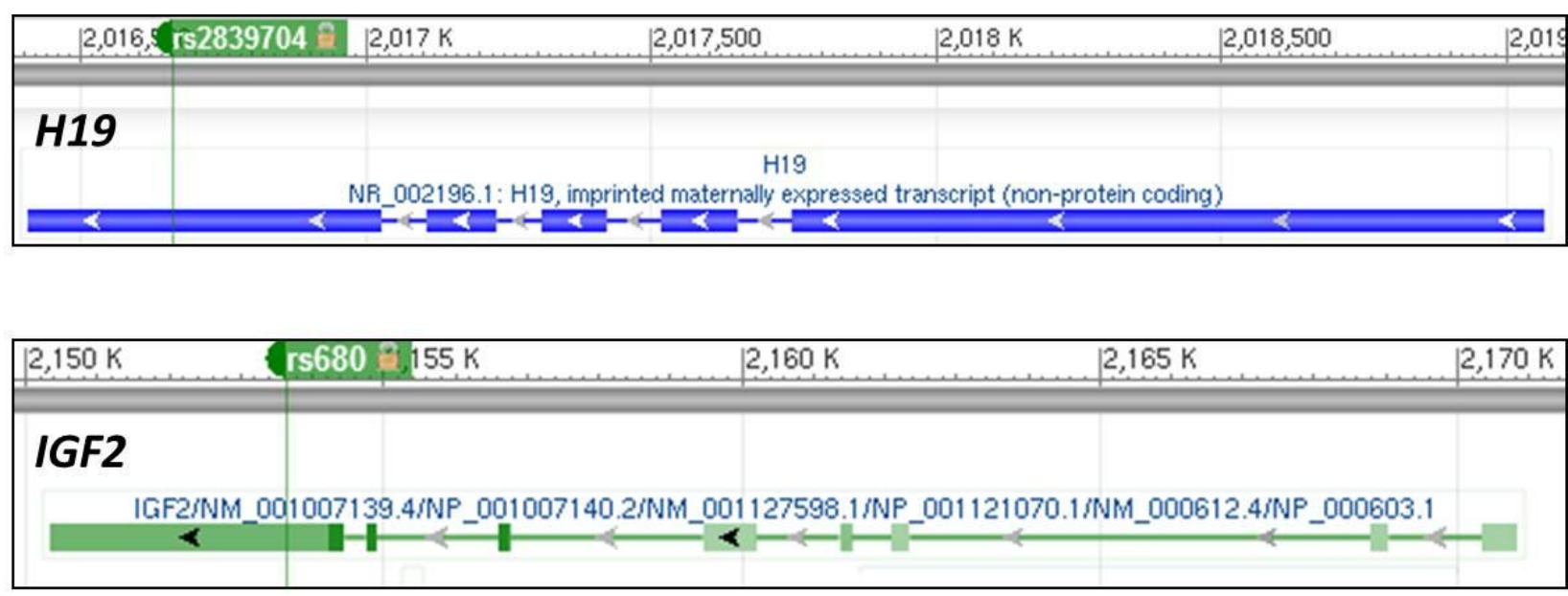

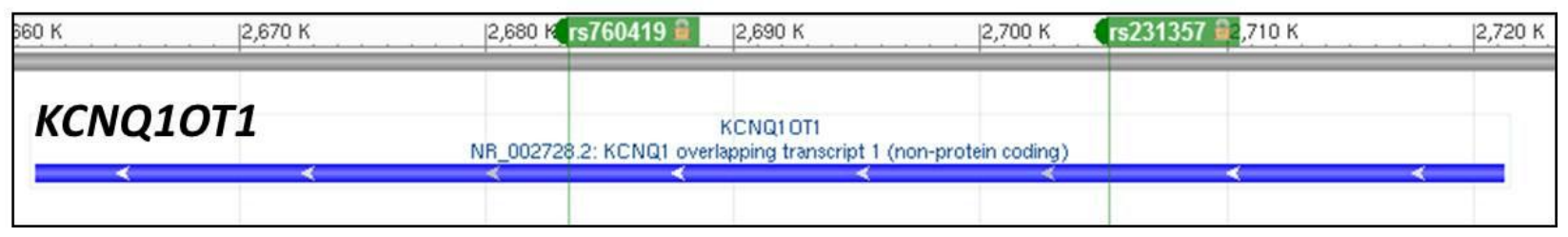

Figura 9. Posição física dos SNPs selecionados nos genes H19 (rs2839704), IGF2 (rs680) e KCNQ1OT1 (rs760419 e rs231357). As coordenadas são do Genoma 37.3 (NCBI).

A reação de minissequenciamento foi composta por $5 \mu \mathrm{l}$ de $S N a P$ shot Multiplex Ready Reaction Mix, $1 \mu$ de produto da PCR purificado, 0,25 $\mu \mathrm{M}$ de SNaPshot primer e $3,7 \mu$ de água ultrapura em um volume final de $10 \mu$. As reações para cada SNP foram realizadas separadamente. A solução foi levada ao termociclador GeneAmp 9700 (Applied Biosystems), e passou pelos seguintes estágios de 25 ciclos: desnaturação a $96{ }^{\circ} \mathrm{C}$ por 10 segundos; pareamento a $50{ }^{\circ} \mathrm{C}$ por 5 segundos; e extensão a $60^{\circ} \mathrm{C}$ por 30 segundos.

Posteriormente, a mistura de reação foi incubada a $37^{\circ} \mathrm{C}$ por uma hora com uma unidade da Shrimp Alkaline Phosphatase-SAP (Promega). A remoção do fosfato 5 ' altera a migração dos ddNTPs fluorescentes não incorporados, inibindo sua interferência no eletroferograma.

Para eletroforese capilar, $1 \mu$ da mistura de reação purificada foi adicionado a uma solução contendo 8,75 $\mu$ de formamida (Hi-Di Formamide, Applied Biosystems) e 0,25 $\mu$ do padrão de massa molecular GeneScan LIZ 120 (Applied Biosystems). O material foi submetido à eletroforese capilar com o polímero POP 4 (Applied Biosystems), utilizando a plataforma $A B I$ Prism $^{T M} 310$ Genetic Analyzer. Os perfis eletroforéticos foram analisados utilizando o programa GeneScan ${ }^{T M}$ (Applied Biosystems). Os alelos foram identificados pela diferença entre os fluorocromos dos 
quatro ddNTPs. Mesmo possuindo amplicons do mesmo tamanho, os indivíduos heterozigotos são identificados pela migração diferencial dos diferentes fluorocromos. A figura 10 mostra o resumo das etapas realizadas para 0 minissequenciamento.

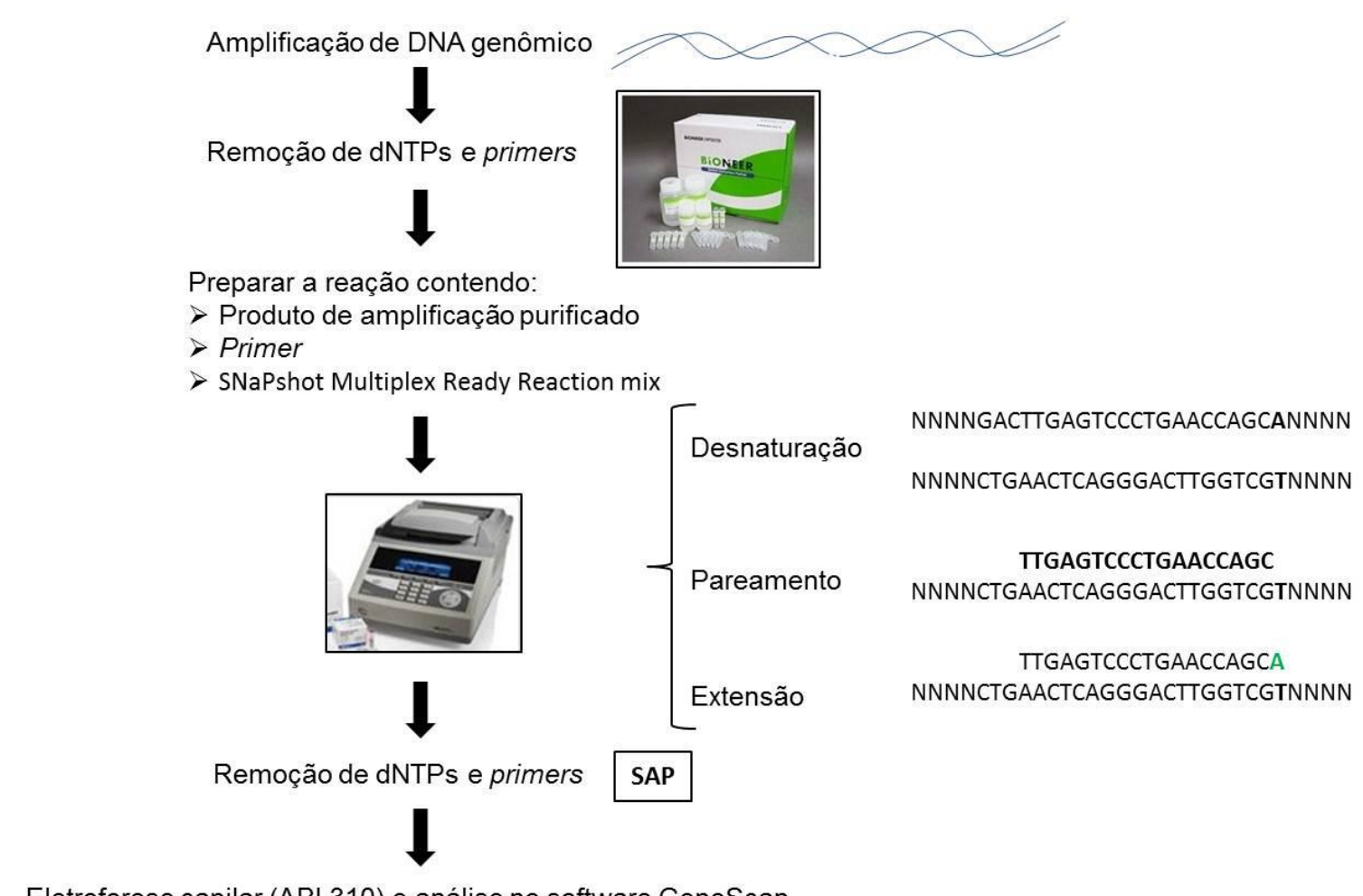

Eletroforese capilar (ABI 310) e análise no software GeneScan
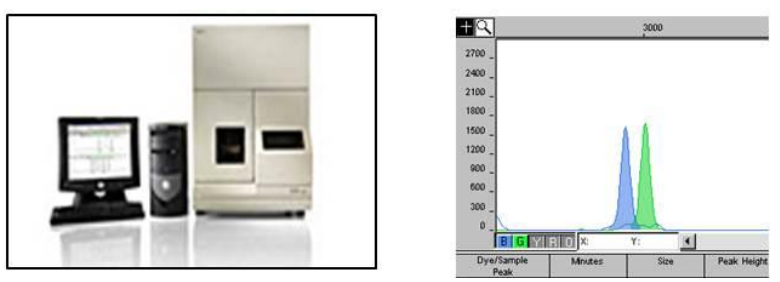

Figura 10. Resumo das etapas para genotipagem de SNPs por minissequenciamento. Modificado do manual do kit SNapShot (Applied Biosystems). 
RESULTADOS 


\section{RESULTADOS}

\subsection{Análises in silico}

Com os critérios utilizados, foram encontrados 378 microssatélites pentanucleotídeos e 1188 tetranucleotídeos no cromossomo 11. Entre a ICR1 e ICR2 foram encontrados quatro marcadores tetranucleotídeos e um pentanucleotídeo. Um marcador com identidade $<90 \%$ foi incluído nos critérios de seleção, pois se encontra a $10 \mathrm{~kb}$ de distância do gene CDKN1C e apresentou polimorfismo in silico. No cromossomo 7, foram encontrados 1576 tetranucleotídeos e 440 pentanucleotídeos. A informatividade dos novos marcadores selecionados nos cromossomos 7 e 11 observada in silico, é indicada nas tabelas 9 e 10.

Os marcadores foram nomeados de acordo com a posição física do início da repetição in silico, seguido pelo prefixo D7S (cromossomo 7) ou D11S (cromossomo 11). Primers marcados com diferentes fluorocromos foram desenhados para os microssatélites, com amplicons variando de 135 a 415 pares de nucleotídeos (Tabela 11). Os marcadores do cromossomo 11 foram selecionados principalmente entre as ICRs 1 e 2, os demais, espaçados visando abranger todo o cromossomo. No cromossomo 7 os marcadores foram selecionados espaçadamente visando abranger pontos representativos de todo cromossomo e próximos a genes sujeitos ao imprinting (Tabela 12).

A figura 11 mostra a validação do polimorfismo in silico do marcador que denominamos D11S2703706, tendo sido observados três alelos em três genomas referência. A posição dos novos marcadores no mapa físico/genético do cromossomo 7 está plotada na figuras 12. A figura 13 mostra a posição dos novos marcadores no mapa do cromossomo 11. 
Tabela 9. Informatividade dos novos marcadores selecionados nos três cromossomos 7 referência.

\begin{tabular}{|c|c|c|c|c|c|c|c|c|c|c|c|c|c|}
\hline \multicolumn{4}{|c|}{ NC 000007.13} & \multicolumn{4}{|c|}{ AC $\quad 000054.1$} & \multicolumn{4}{|c|}{ AC $\quad 000139.1$} & \multirow{2}{*}{\multicolumn{2}{|c|}{$\begin{array}{l}\delta \\
\frac{y}{0} \\
\vdots \\
\frac{c}{d} \\
\frac{d}{a} \\
\frac{d}{d} \\
\frac{c}{2}\end{array}$}} \\
\hline 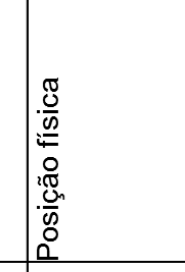 & 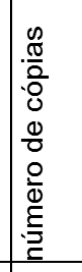 & 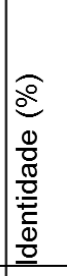 & 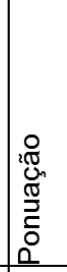 & 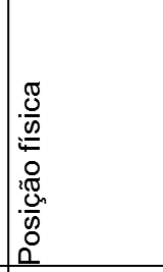 & 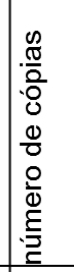 & 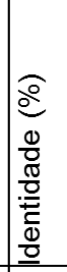 & 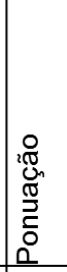 & 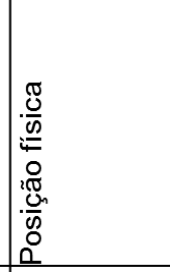 & 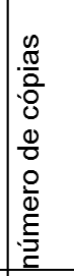 & 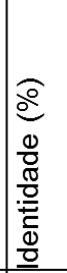 & 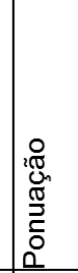 & & \\
\hline 13048278 & 26,0 & 94 & 145 & 3016895 & 27,8 & 94 & 159 & 2966865 & 28,0 & 94 & 161 & AGGA & 3 \\
\hline \begin{tabular}{l|l}
2 & 50192261 \\
\end{tabular} & 11,0 & 100 & 88 & 50286369 & 12,0 & 100 & 96 & 50073106 & 12,0 & 100 & 96 & TTTA & 2 \\
\hline \begin{tabular}{|l|l|}
3 & 94572116 \\
\end{tabular} & 13,5 & 100 & 108 & 89270261 & 12,5 & 100 & 100 & 89179324 & 11,5 & 100 & 92 & AATA & 3 \\
\hline $\begin{array}{lll}4 & 113934919 \\
\end{array}$ & 18,8 & 94 & 114 & 108741416 & 16,8 & 93 & 98 & 108298829 & 16,8 & 93 & 98 & ATAC & 2 \\
\hline 130090835 & 23,3 & 97 & 177 & 124886609 & 22,3 & 97 & 169 & 124452901 & 21,3 & 97 & 161 & AGAA & 3 \\
\hline $\begin{array}{ll}6 & 157620055 \\
\end{array}$ & 9,8 & 100 & 98 & 152043894 & 9,8 & 100 & 98 & 151348509 & 10,8 & 100 & 108 & CACAA & 2 \\
\hline
\end{tabular}

Tabela 10. Informatividade dos novos marcadores selecionados nos três cromossomos 11 referência.

\begin{tabular}{|c|c|c|c|c|c|c|c|c|c|c|c|c|c|c|}
\hline & \multicolumn{4}{|c|}{ NC 000011.9} & \multicolumn{4}{|c|}{ AC 000054.1} & \multicolumn{4}{|c|}{ AC 000143.1} & \multirow{2}{*}{\multicolumn{2}{|c|}{$\frac{1}{2}$}} \\
\hline & 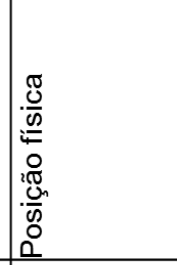 & 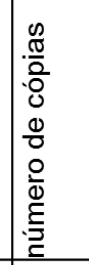 & 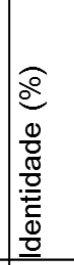 & 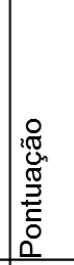 & 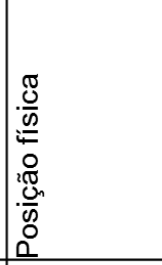 & 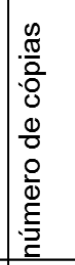 & 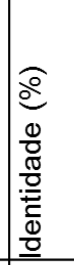 & 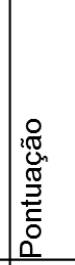 & 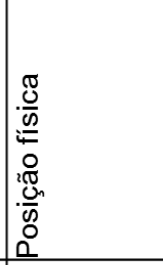 & 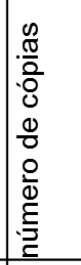 & 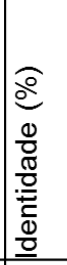 & 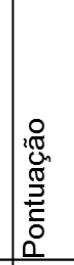 & & \\
\hline 1 & 1790947 & 9,8 & 100 & 78 & 1829064 & 8,8 & 100 & 70 & 1581952 & 7,8 & 100 & 62 & AAAT & 3 \\
\hline 2 & 2255058 & 23,4 & 90 & 188 & 2290826 & 21,4 & 89 & 168 & 2159966 & 20,4 & 86 & 138 & TTATT & 3 \\
\hline 3 & 2479864 & 13,3 & 100 & 106 & 2514691 & 12,3 & 100 & 98 & 2269476 & 12,3 & 100 & 98 & TGGA & 2 \\
\hline 4 & 2589503 & 8,3 & 100 & 66 & 2624345 & 8,3 & 100 & 66 & 2378873 & 9,3 & 100 & 74 & ATAA & 2 \\
\hline 5 & 2703706 & 8,0 & 100 & 64 & 2738540 & 10,0 & 100 & 80 & 2492279 & 9,0 & 100 & 72 & GAGT & 3 \\
\hline 6 & 2835854 & 9,0 & 100 & 72 & 2870621 & 8,0 & 100 & 64 & 2624348 & 8,0 & 100 & 64 & AAGG & 2 \\
\hline 7 & 2894116 & 11,0 & 85 & 61 & 2928820 & 13,0 & 84 & 70 & 2682340 & 17,0 & 90 & 109 & ATTT & 3 \\
\hline 8 & 3146034 & 9,3 & 93 & 65 & 3180775 & 11,3 & 95 & 81 & 2935749 & 11,3 & 95 & 81 & ATGG & 2 \\
\hline 9 & 32391821 & 26,5 & 94 & 149 & 32538556 & 26,5 & 94 & 149 & 32086751 & 25,5 & 93 & 141 & AAGG & 2 \\
\hline 10 & 66219036 & 14,8 & 92 & 123 & 63539068 & 13,8 & 95 & 122 & 62547008 & 12,8 & 95 & 112 & TTCTA & 3 \\
\hline 11 & 99794463 & 19,3 & 92 & 120 & 96963806 & 20,3 & 91 & 119 & 95730454 & 21,3 & 92 & 118 & TATC & 3 \\
\hline 1 & 134777313 & 12,3 & 100 & 98 & 131948022 & 11,3 & 100 & 90 & 130730457 & 10,3 & 100 & 82 & AAAC & 3 \\
\hline
\end{tabular}


Tabela11. Novos marcadores selecionados nos cromossomo 7 e 11, com seus respectivos primers, fluorocromos utilizados (VIC, NED; PET; FAM) e comprimento dos amplicons.

\begin{tabular}{|l|l|l|l|}
\hline Cromossomo 7 & Primer forward & Primer reverse & Amplicon (pb) \\
\hline D7S3048278 & VIC-CCCAAACCACAAGATGGAAT & ACCGGGTCACATTGAACATT & 382 \\
\hline D7S50192261 & NED-GGCCCAGTGCAGATGAATA & CCAGGAGAAAGGGTTGCAG & 245 \\
\hline D7S94572116 & PET-CAGGGGATCACTTGAACCT & CCATCTTTTAGCTCACCCAGA & 316 \\
\hline D7S113934919 & NED-TGCAGTGAGCTGGGATTGT & CGGATAGTTCCAAGCCACA & 323 \\
\hline D7S130090654 & FAM-GAATCTGGGAGGTGGAGGTT & ACAGCAGCCCACCATTTTAT & 351 \\
\hline D7S157620055 & FAM-AGAGGTGGGCACCCATTTA & GGGACATTCTGATCGAGCTT & 135 \\
\hline Cromossomo11 & & & \\
\hline D11S1790947 & FAM-CGTTGTGCACCTGTACCCTA & AGCCCATTCATCAAGACAGG & 206 \\
\hline D11S2255058 & PET-TGGGCTCAAGTGATCCTTTC & TCATCACTTTGTCCTGGAACAT & 349 \\
\hline D11S2479864 & NED-CACAGAAAGGCTCCCATCC & ACCACTGGGATTCTGCAAGT & 200 \\
\hline D11S2589503 & PET-GAGGCAGAGGTTGCAGTGA & GAGACAGGGTGCCCATGA & 257 \\
\hline D11S2703706 & FAM-TGAGGGTATAGGCTGGCTGT & AGGGTCCTAGCACCTGGTTT & 159 \\
\hline D11S2835854 & VIC-GGATGGGTAGATGGATGGAA & GAGGAAAGCTGTGTGTGCAG & 415 \\
\hline D11S2894116 & NED-CCAAGGGTAGATGCCAGGTA & CAGCCTGACAAACATGGAGA & 307 \\
\hline D11S3146034 & VIC-ACCCTACTGCCCATTCACAC & TCCCCTGTTGCCTCAAATAC & 182 \\
\hline D11S32391821 & NED-GGACACAGCAAAACCATATCAA & TTTGAGCCTGCAGTGAGCTA & 400 \\
\hline D11S66219036 & FAM-GAGGGTCACACAGGCTATGC & AGGCTTTTTGCAAGGTAGGG & 325 \\
\hline D11S99794463 & VIC-TCCAAACTGCTTTCCACAGA & GGTGTGCGCCTGTAGTACCT & 299 \\
\hline D11S134777313 & PET-GGAGGTTGTGGGAGCTGAG & CCTGTACAGCAAAGGGCATC & 154 \\
\hline
\end{tabular}

Tabela 12: Distância dos novos marcadores em relação aos genes sujeitos ao imprinting e origem parental do alelo expresso.

\begin{tabular}{|c|c|c|c|}
\hline Marcador & Distância de gene imprinted (kb) & Gene & Alelo expresso \\
\hline D7S3048278 & 26540 & COPG2IT1 & paterno \\
\hline D7S50192261 & 334 & $D D C$ & isoforma dependente \\
\hline D7S94572116 & 0 (íntron 2) & PPP1R9A & materno \\
\hline D7S113934919 & 15998 & CPA4 & materno \\
\hline D7S130090654 & 35 & MEST & paterno \\
\hline D7S157620055 & 27203 & KFL14 & materno \\
\hline D11S1790947 & 225 & $H 19$ & materno \\
\hline D11S2255058 & 73 & INS & paterno \\
\hline D11S2479864 & 0 (Íntron 1) & KCNQ1 & materno \\
\hline D11S2589503 & 0 (Íntron 2) & KCNQ1 & materno \\
\hline \multirow{2}{*}{ D11S2703706 } & 0 (Íntron 11) & KCNQ1 & materno \\
\hline & 0 (éxon 1) & KCNQ10T1 & paterno \\
\hline D11S2835854 & 0 (Íntron 15) & KCNQ1 & materno \\
\hline D11S2894116 & 10 & CDKN1C & materno \\
\hline D11S3146034 & 41 & OSBPL5 & materno \\
\hline D11S32391821 & 18 & WT1 & paterno \\
\hline D11S66219036 & 33762 & WT1 & paterno \\
\hline D11S99794463 & 67337 & WT1 & paterno \\
\hline D11S134777313 & 102320 & WT1 & paterno \\
\hline
\end{tabular}




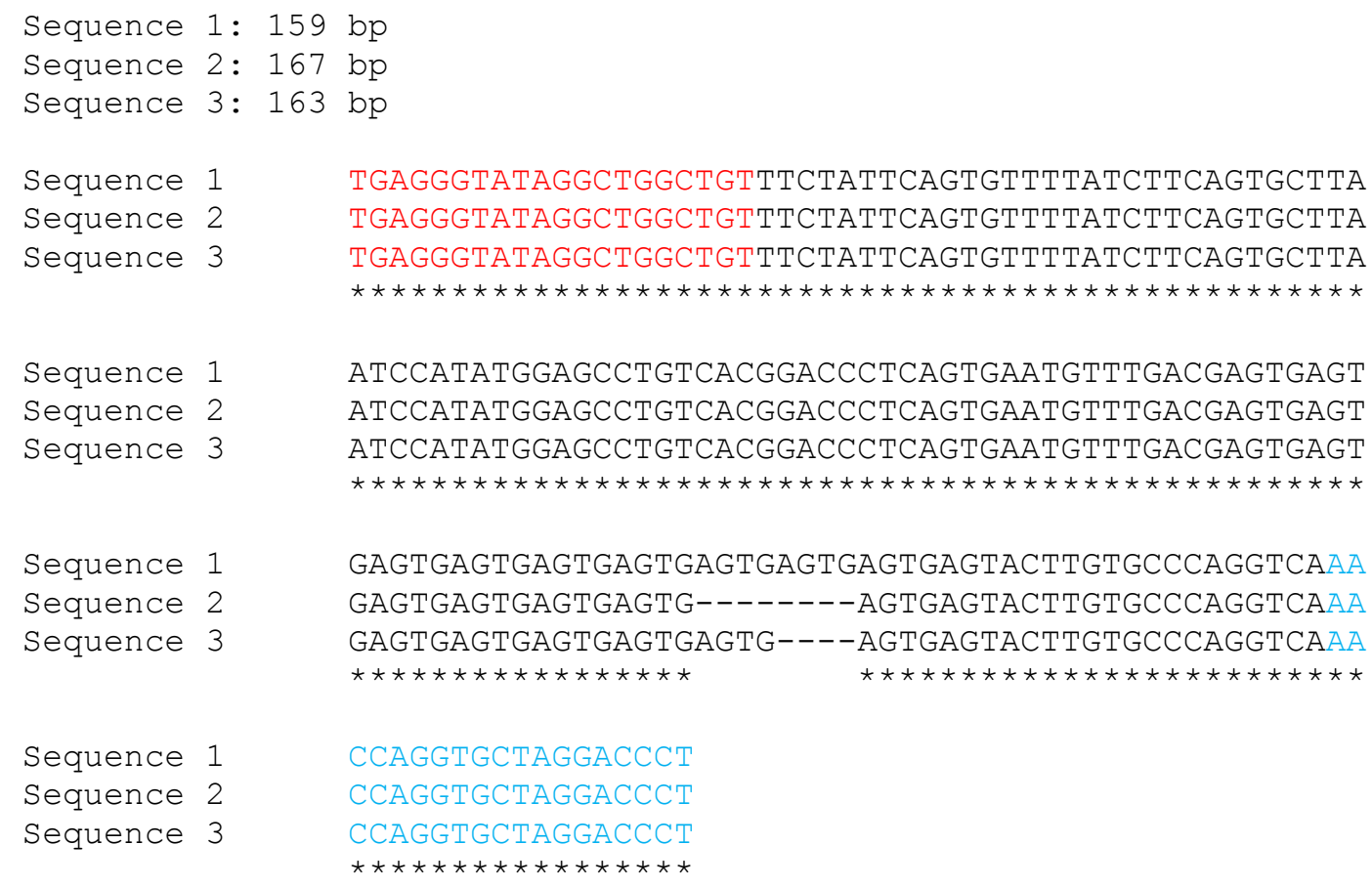

Figura 11. Validação in silico do locus D11S2703706. Em vermelho e em azul são realçados os sítios de pareamento dos primers forward e reverse, respectivamente. Os produtos da amplificação variam de 159 a 167 pares de nucleotídeos para os três genomas referência. 


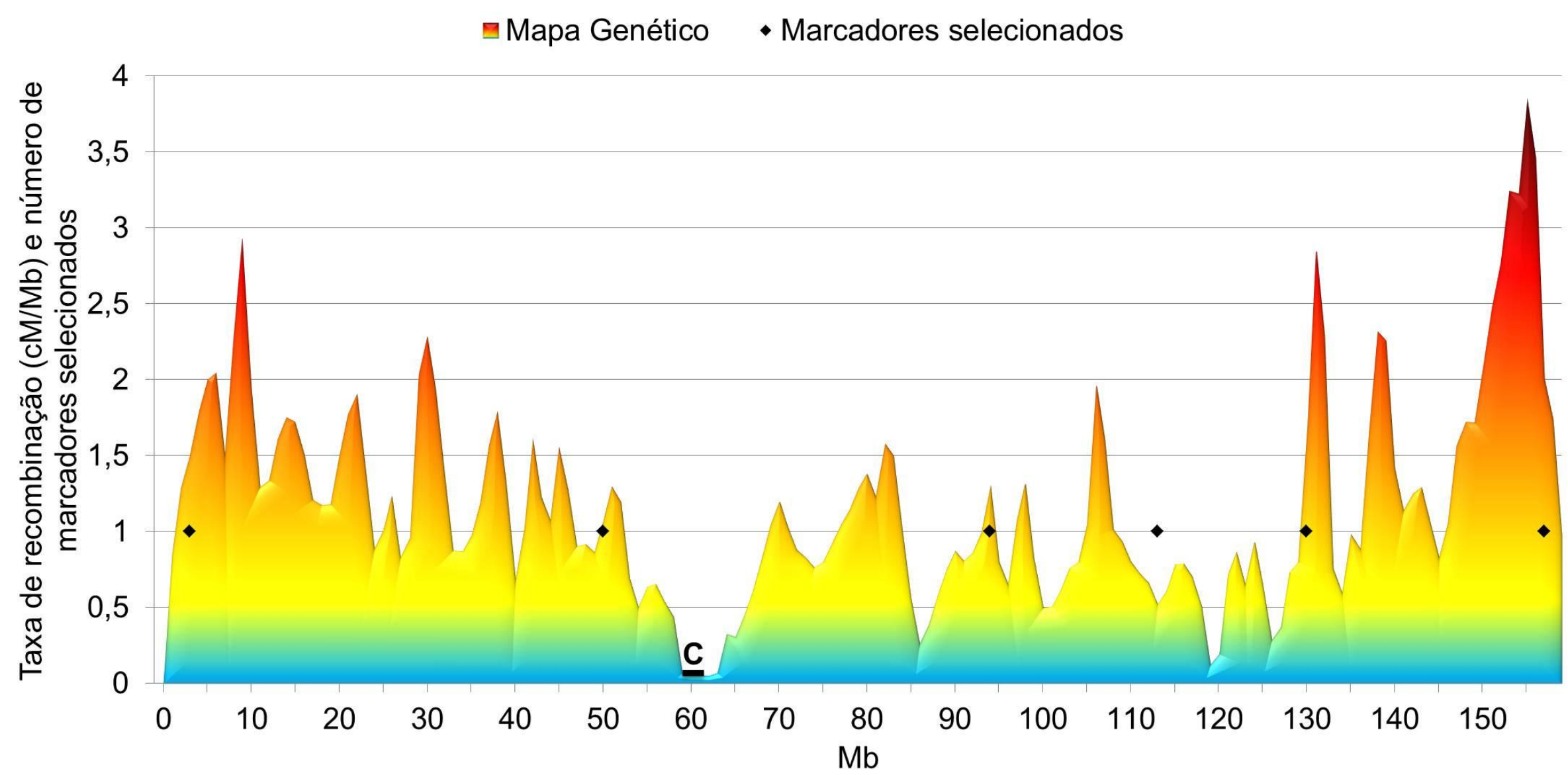

Figura 12. Mapa genético do cromossomo 7 e posição dos microssatélites selecionados. Em colorido, as taxas de recombinação em centimorgan por megabase (cM/Mb); o vermelho representando altas e o azul baixas taxas de recombinação. Eixo x: tamanho do cromossomo 7 em Mb. Os losangos representam, no eixo x, a posição física dos marcadores selecionados e o número de marcadores, no eixo y. C: Centrômero. 


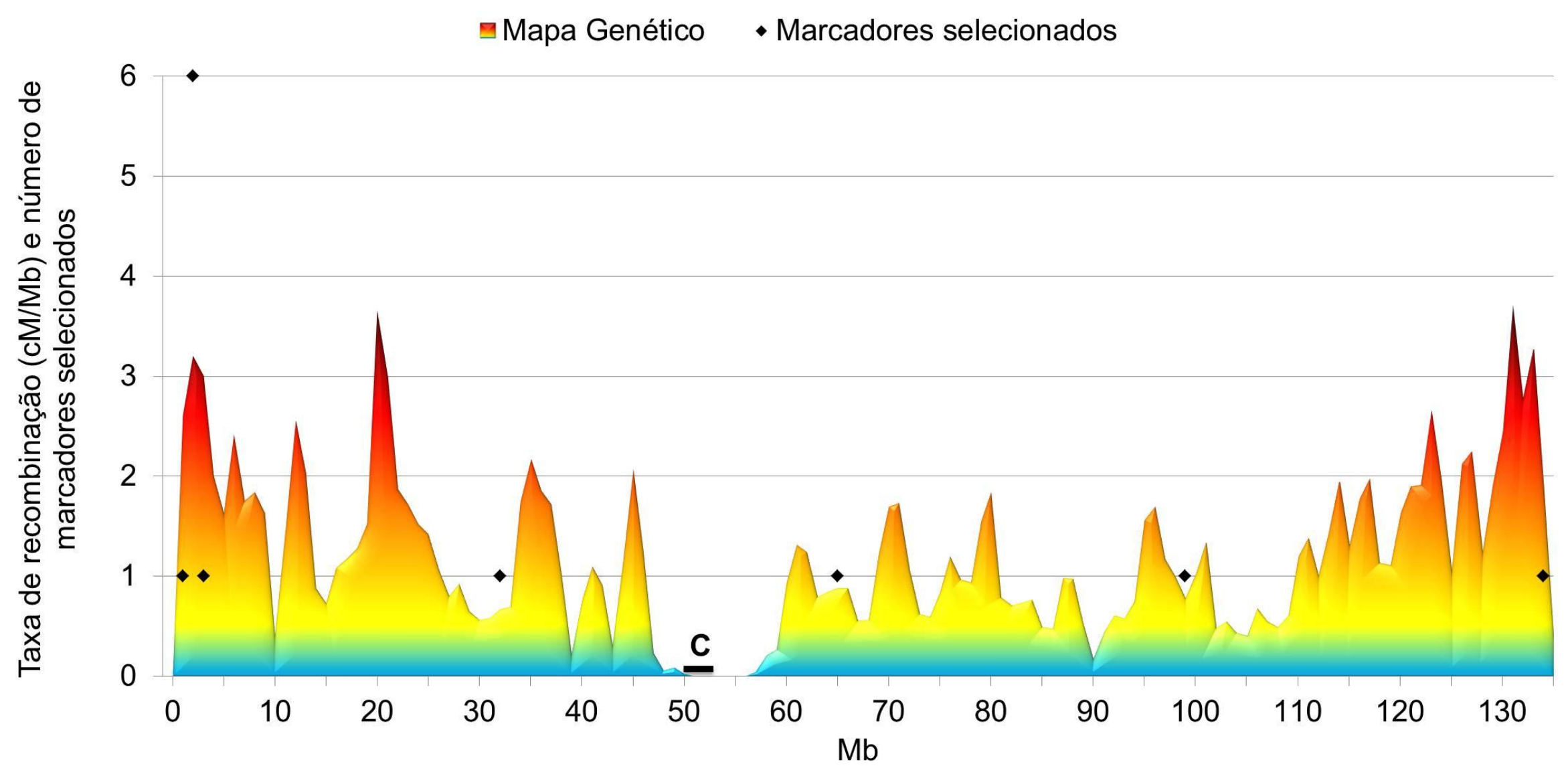

Figura 13. Mapa genético do cromossomo 11 e posição dos microssatélites selecionados. Em colorido, as taxas de recombinação em centimorgan por megabase (cM/Mb); o vermelho representando altas e o azul baixas taxas de recombinação. Eixo x: tamanho do cromossomo 11 em Mb. Os losangos representam, no eixo x, a posição física dos marcadores selecionados e o número de marcadores, no eixo y. C: Centrômero. 


\subsection{Validação in vitro dos novos marcadores}

Os marcadores selecionados foram validados nos pacientes com SSR e seus pais, quando disponíveis. A tabela 13 mostra a frequência dos alelos observados e a heterozigose para marcadores do cromossomo 7. Não foi obtido êxito na amplificação do marcador D7S94572116. O marcador mais informativo foi o D7S157620055 com heterozigose observada de $80,6 \%$. A frequência alélica do marcador D7S130090654 não foi determinada. A figura 14 ilustra exemplos de genótipos observados dos novos marcadores no cromossomo 7.

Tabela 13. Frequência alélica e heterozigose observada (het obs) dos marcadores do cromossomo 7.

\begin{tabular}{|c|c|c|c|}
\hline Marcador & Alelos observados & Frequência & Het obs \\
\hline \multirow{7}{*}{ D7S3048278 $(n=31)$} & 369 & 0,13 & \multirow{7}{*}{$67,7 \%$} \\
\hline & 377 & 0,24 & \\
\hline & 381 & 0,02 & \\
\hline & 385 & 0,08 & \\
\hline & 387 & 0,13 & \\
\hline & 391 & 0,39 & \\
\hline & 395 & 0,02 & \\
\hline \multirow{4}{*}{ D7S50192261 (n=29) } & 247 & 0,38 & \multirow{4}{*}{$65,5 \%$} \\
\hline & 251 & 0,36 & \\
\hline & 255 & 0,24 & \\
\hline & 259 & 0,02 & \\
\hline \multirow{5}{*}{ D7S113934919 $(n=30)$} & 313 & 0,05 & \multirow{5}{*}{$66,7 \%$} \\
\hline & 317 & 0,08 & \\
\hline & 321 & 0,57 & \\
\hline & 325 & 0,27 & \\
\hline & 329 & 0,03 & \\
\hline \multirow{6}{*}{ D7S157620055 (n=31) } & 120 & 0,05 & \multirow{6}{*}{$80,6 \%$} \\
\hline & 130 & 0,06 & \\
\hline & 135 & 0,40 & \\
\hline & 140 & 0,26 & \\
\hline & 145 & 0,21 & \\
\hline & 155 & 0,02 & \\
\hline
\end{tabular}

(n) número de indivíduos avaliados. 

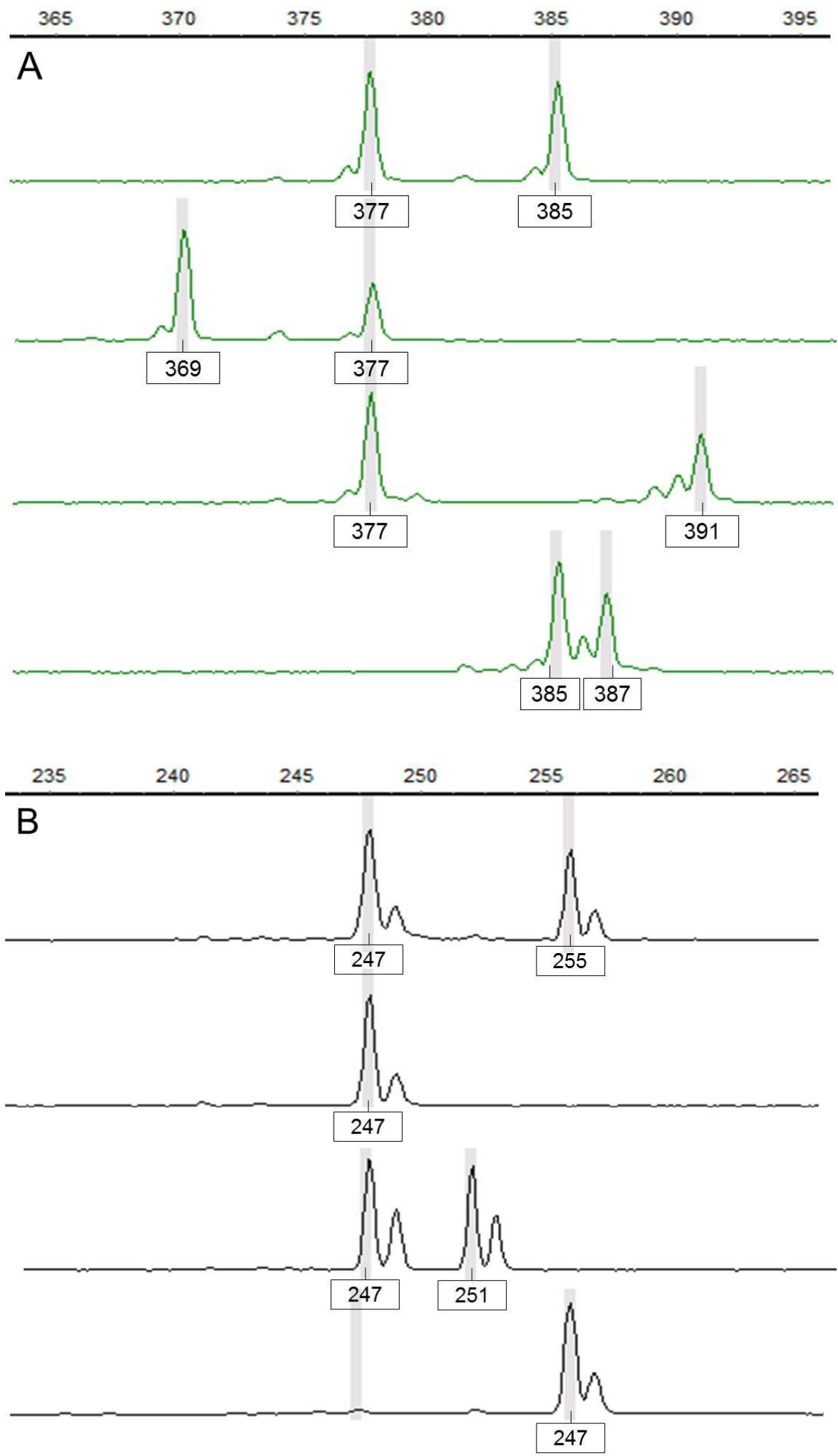

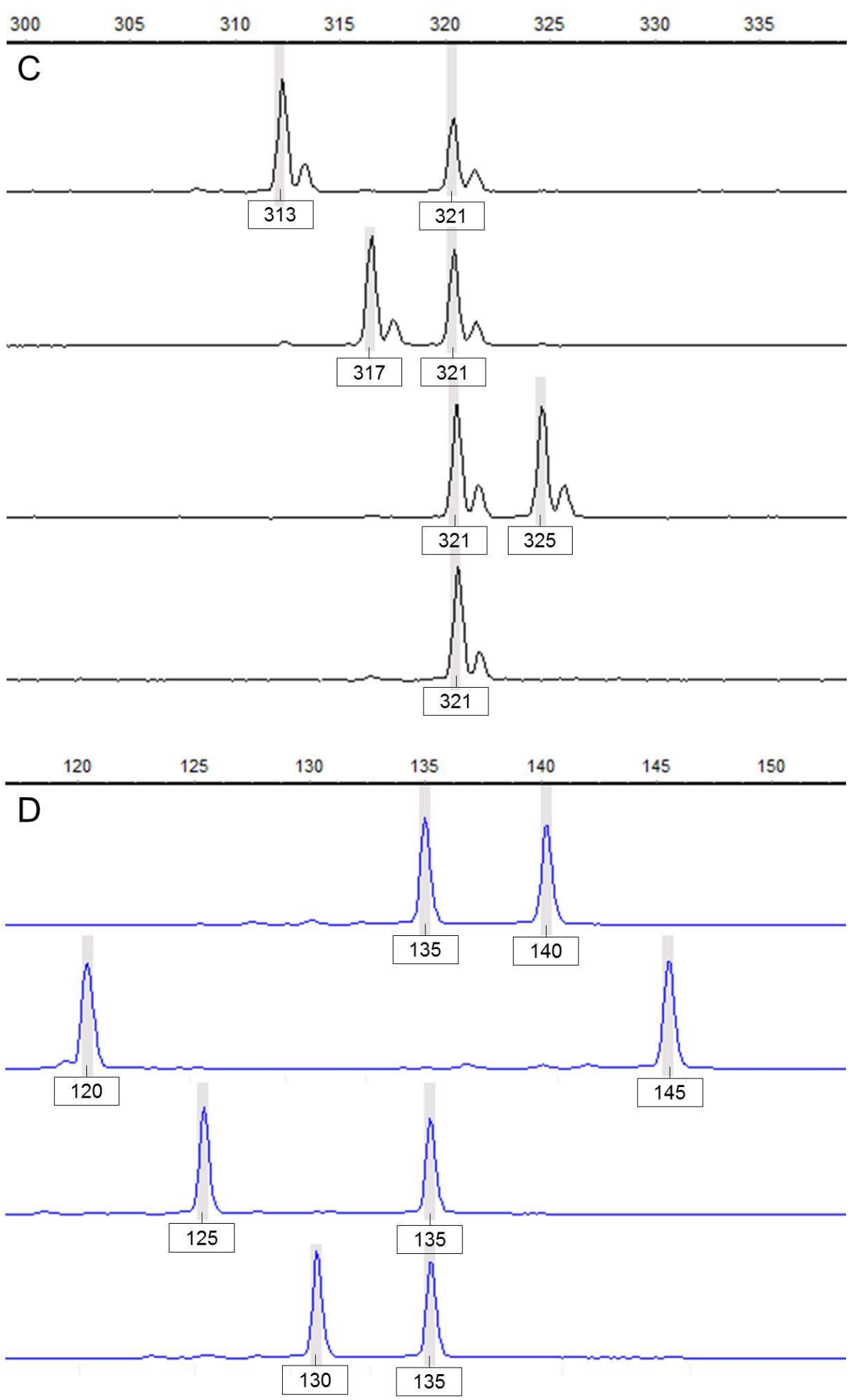

Figura 14. Eletroferograma de novos marcadores no cromossomo 7. Genótipos observados para os marcadores D7S3048278 (A), D7S50192261 (B), D7S113934919 (C) e D7S157620055 (D). Cada linha corresponde corresponde a um indivíduo. Os alelos estão nomeados segundo o tamanho em pares de nucleotídeos. 
Os marcadores D11S2479864, D11S2703706 e D11S2835854 do cromossomo 11, foram primeiramente utilizados para verificar a presença de alterações nesta região nos pacientes com SBW, SSR e HHI. Nos casos positivos, os demais marcadores foram empregados. A frequência alélica e a heterozigose para marcadores do cromossomo 11 são mostradas na tabela 14 . O marcador mais informativo foi o D11S134777313 com heterozigose observada de $90,91 \%$. Não foi determinada a frequência alélica do marcador D11S2589503. A Figura 15 ilustra exemplos de genótipos observados dos novos marcadores no cromossomo 11.

Tabela 14. Frequência alélica e heterozigose observada (het obs) marcadores do cromossomo 7.

\begin{tabular}{|c|c|c|c|}
\hline Marcador & $\begin{array}{c}\text { Alelos } \\
\text { observados }\end{array}$ & Frequência & Het obs \\
\hline \multirow{4}{*}{ D11S1790947 $(n=33)$} & 197 & 0,08 & \multirow{4}{*}{$66,67 \%$} \\
\hline & 201 & 0,23 & \\
\hline & 205 & 0,58 & \\
\hline & 209 & 0,12 & \\
\hline \multirow{5}{*}{ D11S2255058 (n=31) } & 328 & 0,34 & \multirow{5}{*}{$67,74 \%$} \\
\hline & 343 & 0,45 & \\
\hline & 348 & 0,15 & \\
\hline & 353 & 0,05 & \\
\hline & 358 & 0,02 & \\
\hline \multirow{8}{*}{ D11S2479864 $(n=115)$} & 172 & 0,28 & \multirow{8}{*}{$73,04 \%$} \\
\hline & 180 & 0,03 & \\
\hline & 188 & 0,04 & \\
\hline & 197 & 0,03 & \\
\hline & 201 & 0,31 & \\
\hline & 205 & 0,26 & \\
\hline & 209 & 0,05 & \\
\hline & 213 & 0,00 & \\
\hline \multirow{5}{*}{$D 11 S 2703706(n=113)$} & 160 & 0,40 & \multirow{5}{*}{$55,75 \%$} \\
\hline & 164 & 0,06 & \\
\hline & 168 & 0,43 & \\
\hline & 172 & 0,09 & \\
\hline & 176 & 0,01 & \\
\hline \multirow{5}{*}{ D11S2835854 $(n=113)$} & 397 & 0,03 & \multirow{5}{*}{$33,63 \%$} \\
\hline & 405 & 0,04 & \\
\hline & 409 & 0,76 & \\
\hline & 413 & 0,17 & \\
\hline & 417 & 0,01 & \\
\hline \multirow{8}{*}{ D11S2894116 $(n=32)$} & 301 & 0,11 & \multirow{8}{*}{$71,88 \%$} \\
\hline & 309 & 0,34 & \\
\hline & 313 & 0,02 & \\
\hline & 317 & 0,03 & \\
\hline & 321 & 0,03 & \\
\hline & 329 & 0,16 & \\
\hline & 333 & 0,30 & \\
\hline & 337 & 0,02 & \\
\hline
\end{tabular}




\begin{tabular}{|c|c|c|c|}
\hline \multirow{5}{*}{ D11S3146034 (n=33) } & 179 & 0,02 & \multirow{5}{*}{$72,73 \%$} \\
\hline & 183 & 0,33 & \\
\hline & 187 & 0,02 & \\
\hline & 191 & 0,32 & \\
\hline & 195 & 0,32 & \\
\hline \multirow{12}{*}{ D11S32391821 $(n=33)$} & 373 & 0,05 & \multirow{12}{*}{$84,85 \%$} \\
\hline & 377 & 0,14 & \\
\hline & 381 & 0,09 & \\
\hline & 385 & 0,03 & \\
\hline & 387 & 0,02 & \\
\hline & 391 & 0,23 & \\
\hline & 395 & 0,18 & \\
\hline & 399 & 0,18 & \\
\hline & 403 & 0,02 & \\
\hline & 407 & 0,02 & \\
\hline & 411 & 0,03 & \\
\hline & 415 & 0,03 & \\
\hline \multirow{6}{*}{ D11S66219036 $(n=31)$} & 311 & 0,05 & \multirow{6}{*}{$70,97 \%$} \\
\hline & 316 & 0,27 & \\
\hline & 321 & 0,24 & \\
\hline & 326 & 0,26 & \\
\hline & 331 & 0,11 & \\
\hline & 336 & 0,06 & \\
\hline \multirow{7}{*}{ D11S99794463 $(n=30)$} & 287 & 0,02 & \multirow{7}{*}{$73,33 \%$} \\
\hline & 295 & 0,02 & \\
\hline & 299 & 0,23 & \\
\hline & 303 & 0,25 & \\
\hline & 307 & 0,22 & \\
\hline & 311 & 0,18 & \\
\hline & 315 & 0,08 & \\
\hline \multirow{6}{*}{ D11S134777313 (n=33) } & 133 & 0,05 & \multirow{6}{*}{$90,91 \%$} \\
\hline & 137 & 0,08 & \\
\hline & 141 & 0,06 & \\
\hline & 145 & 0,32 & \\
\hline & 149 & 0,27 & \\
\hline & 153 & 0,23 & \\
\hline
\end{tabular}

(n) número de indivíduos avaliados 

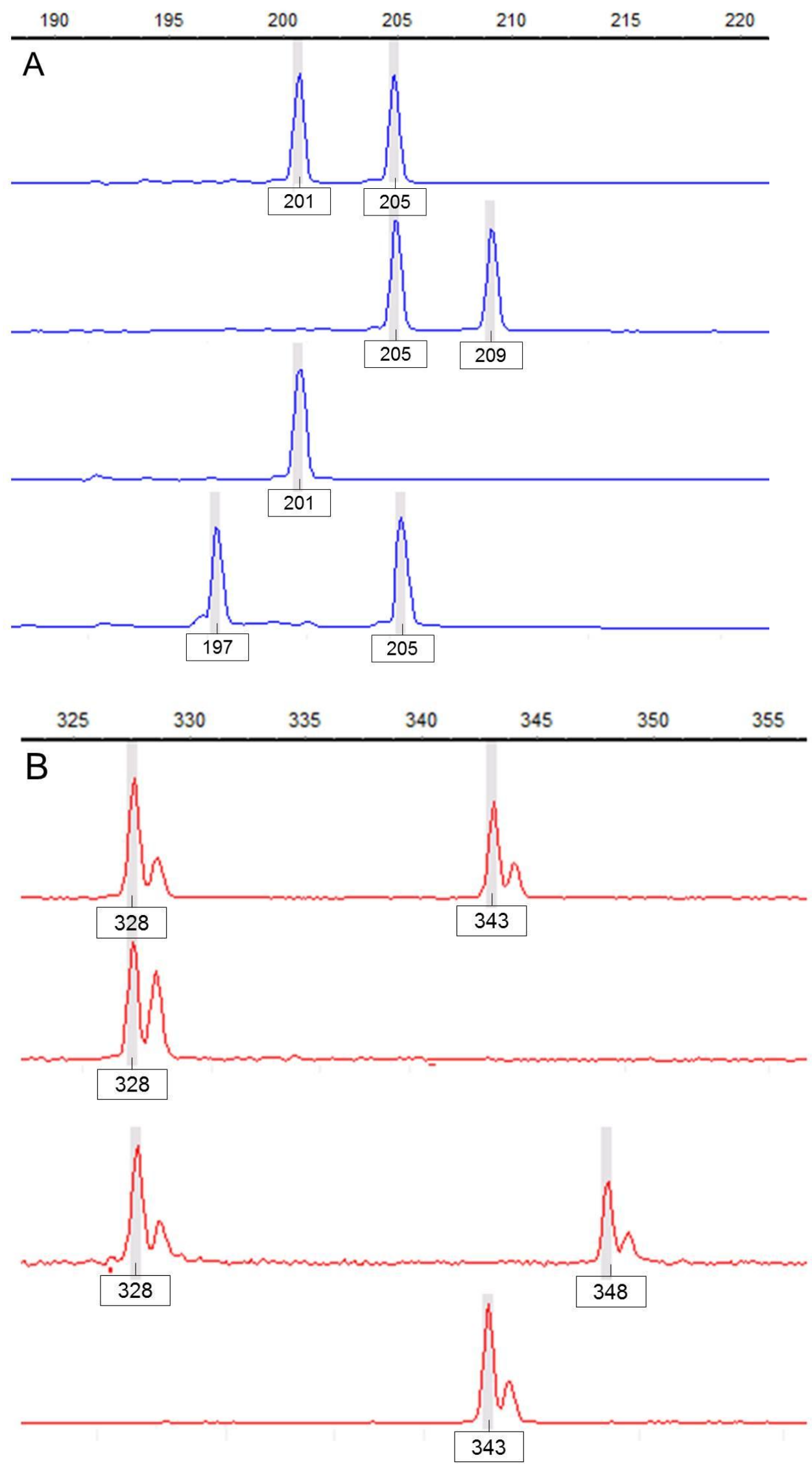

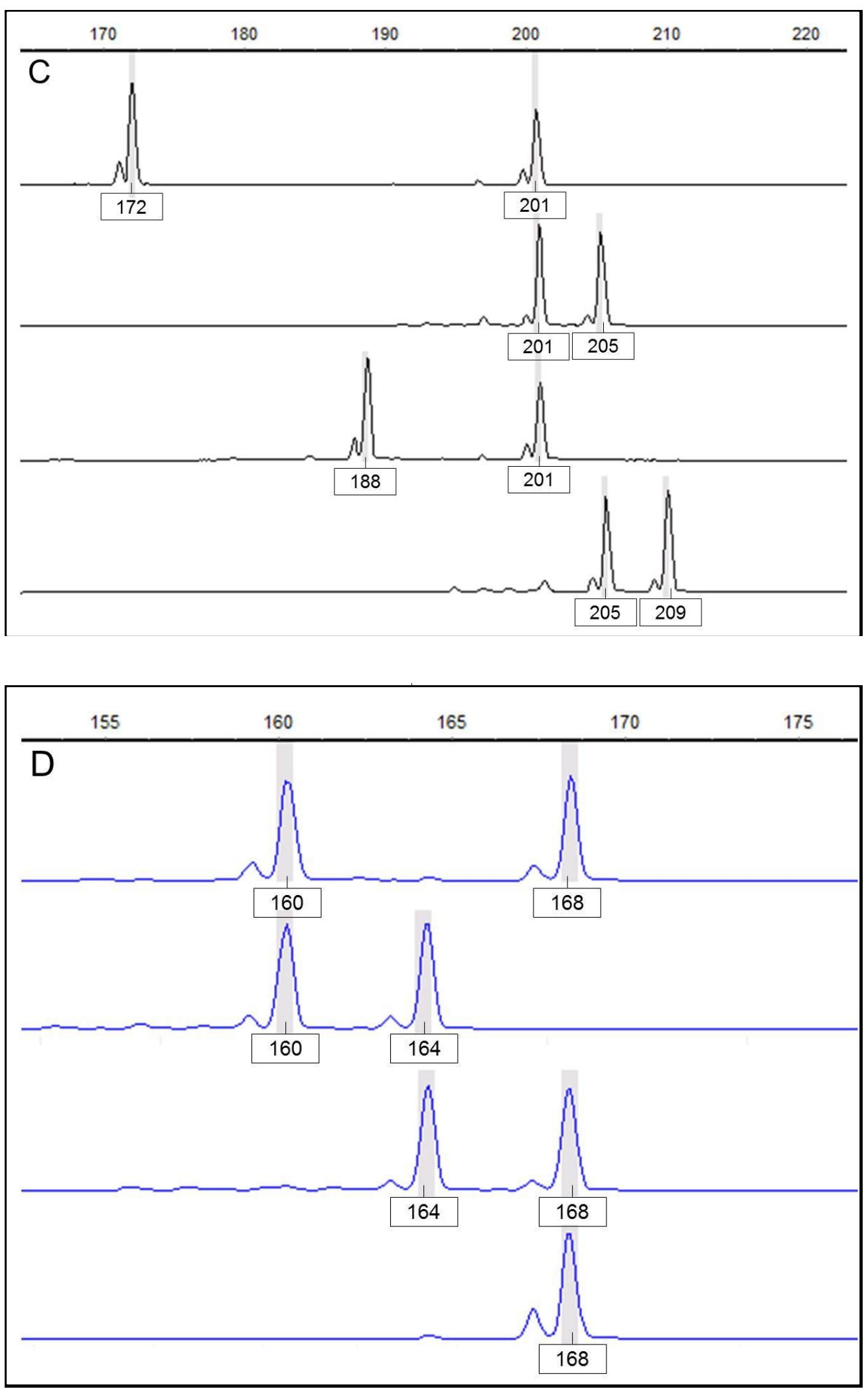


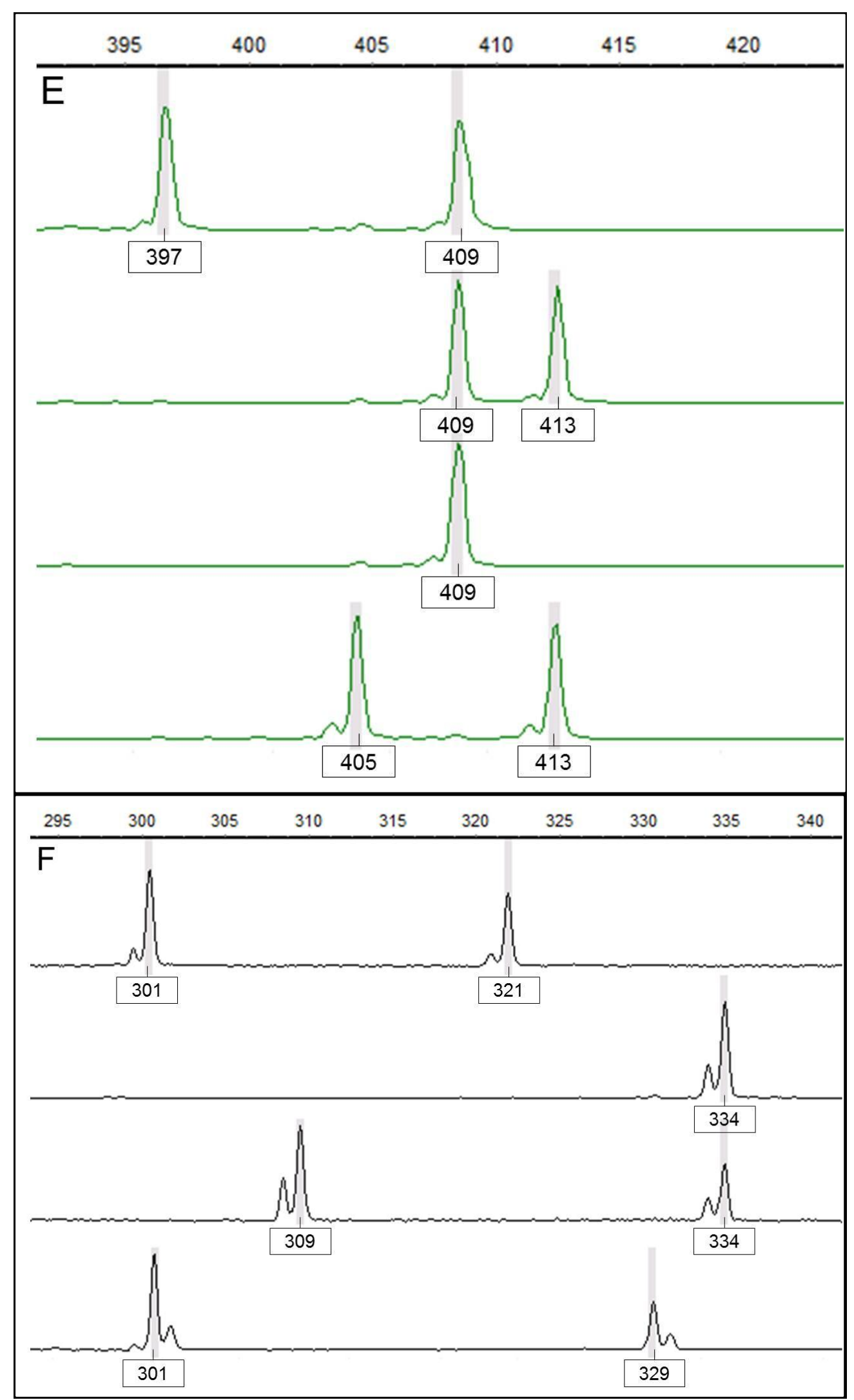




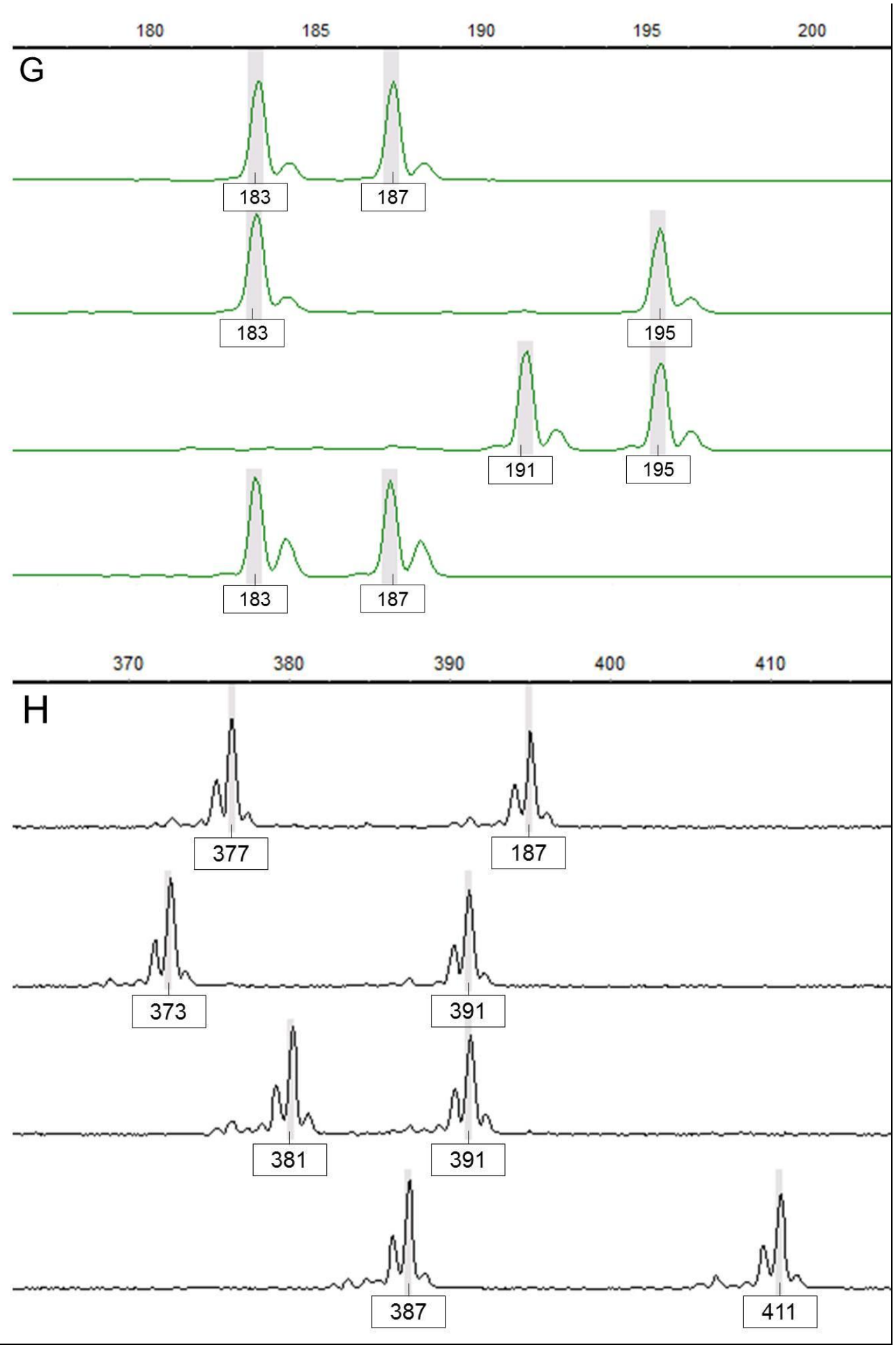




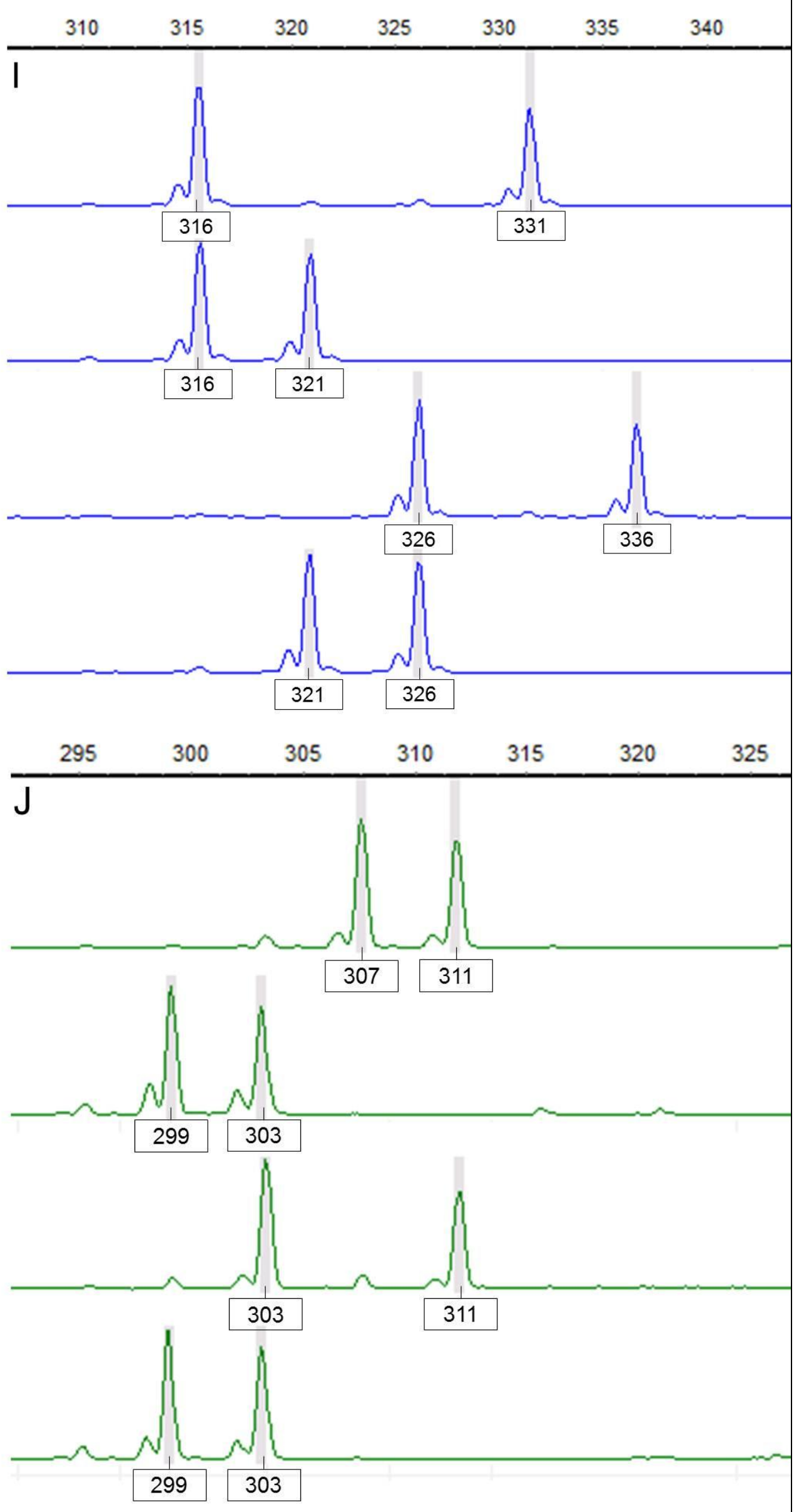




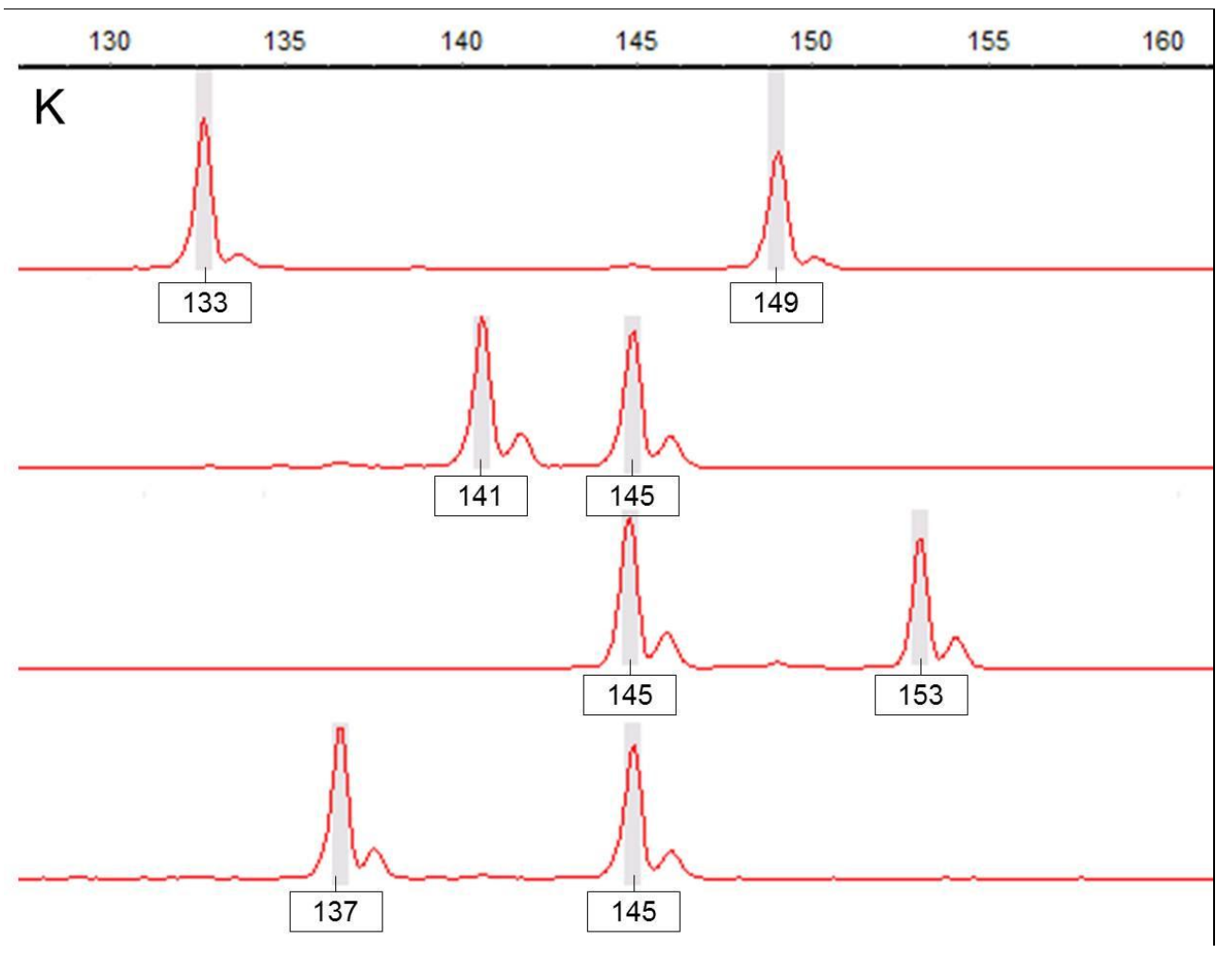

Figura 15. Eletroferograma de novos marcadores no cromossomo 11. Genótipos observados para os marcadores D11S1790947 (A), D11S2255058 (B), D11S2479864 (C), D11S2703706 (D), D11S2835854 (E), D11S2894116 (F), D11S3146034 (G), D11S32391821 (H), D11S66219036 (I), D11S99794463 (J), D11S134777313 (K), D7S50192261. Cada linha corresponde a um indivíduo. Os alelos estão nomeados segundo o tamanho em pares de nucleotídeos.

Em um caso (SBW 228) foi observada duplicação paterna entre os marcadores D11S1790947 e D11S3146034, que abrangem as ICRs 1 e 2. A figura 16 mostra o marcador D11S2894116, indicando o excesso da quantidade de alelo paterno em relação ao materno.

A dissomia uniparental paterna (DUPpat) foi sugerida quando a dosagem alélica paterna foi superior a 3:1 em relação ao alelo materno, pois não há caso descrito de uma triplicação paterna nesta região. Em três pacientes com SBW e dois pacientes com HHI um perfil genético de DUPpat foi observado. Nos paciente SBW 175, SBW 626 e SBW 630 também foram observados perfis genéticos de duplicação paterna, mas posteriormente foi excluído a duplicação pelo ensaio de MLPA, indicando DUPpat. Com exceção do paciente SBW 1351, todos os genitores foram genotipados. Neste caso em particular, concluiu-se que haveria DUPpat pelo fenótipo observado. A 
quantidade de alelos paternos em relação aos maternos variou de 2:1 a 6:1. 0 paciente HHI 209 apresentou 100\% de células com DUPpat em 11p15.5, não apresentando alelos maternos para esta região. A figura 17 ilustra um exemplo de DUPpat.

Todos os casos com DUPpat, apresentaram DUPpat da região 11p15.5, em alguns casos a DUPpat se estendeu até o marcador D11S32391821 em 11p13, não foi observado DUPpat no braço longo do cromossomo (Figura 18). Todos os casos, exceto o SBW 626, foram investigados para dissomia uniparental global em 13 autossomos. Todos os marcadores informativos indicaram herança biparental para as outras regiões estudadas.

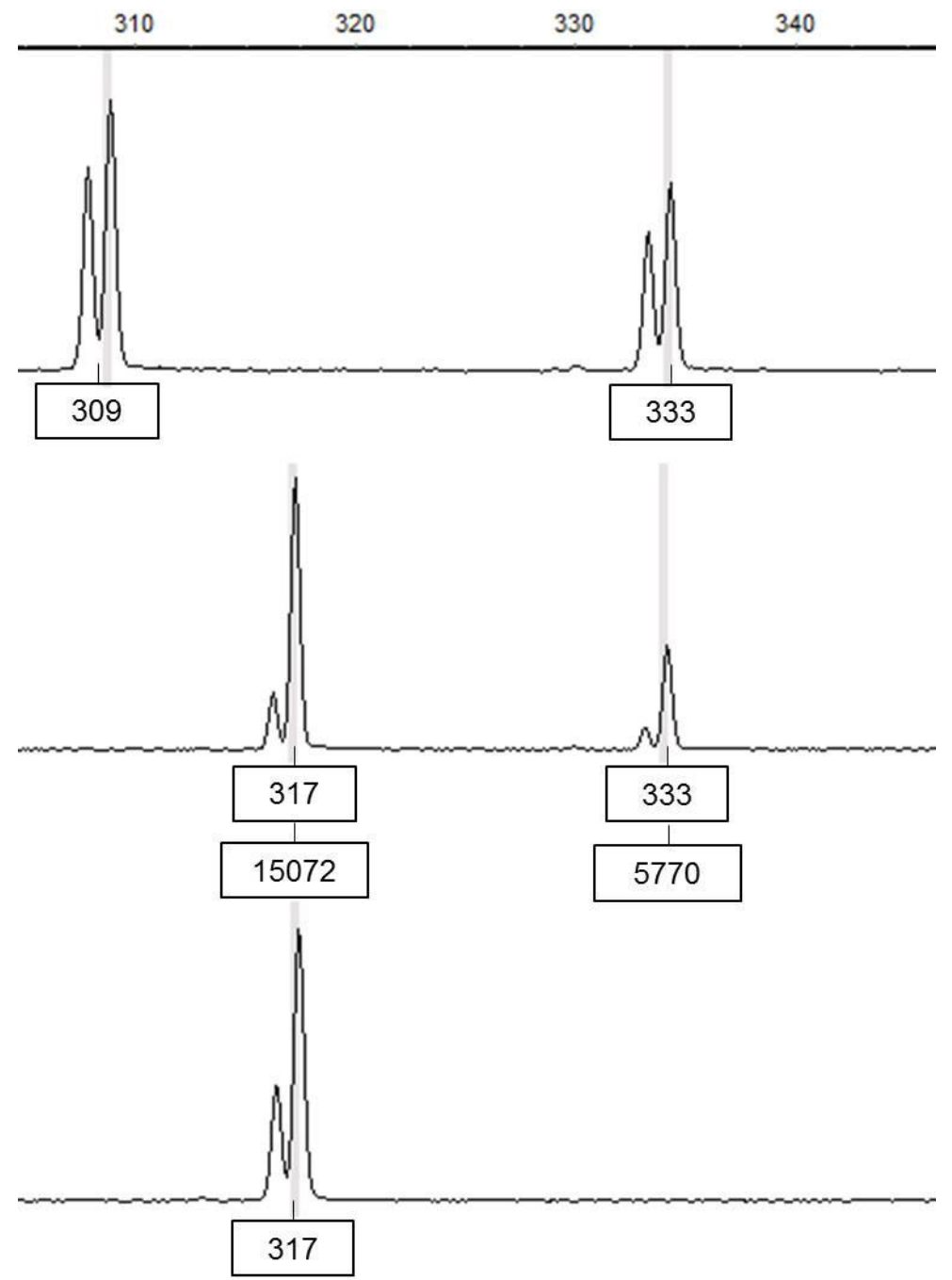

Figura 16. Eletroferograma dos perfis genéticos para o marcador D11S2894116 em núcleo familiar. O filho (painel central) possui excesso do alelo paterno (painel inferior), o genótipo materno é mostrado no painel superior. Os alelos estão representados em pares de nucleotídeos e abaixo dos alelos, estão indicadas as áreas dos picos. 


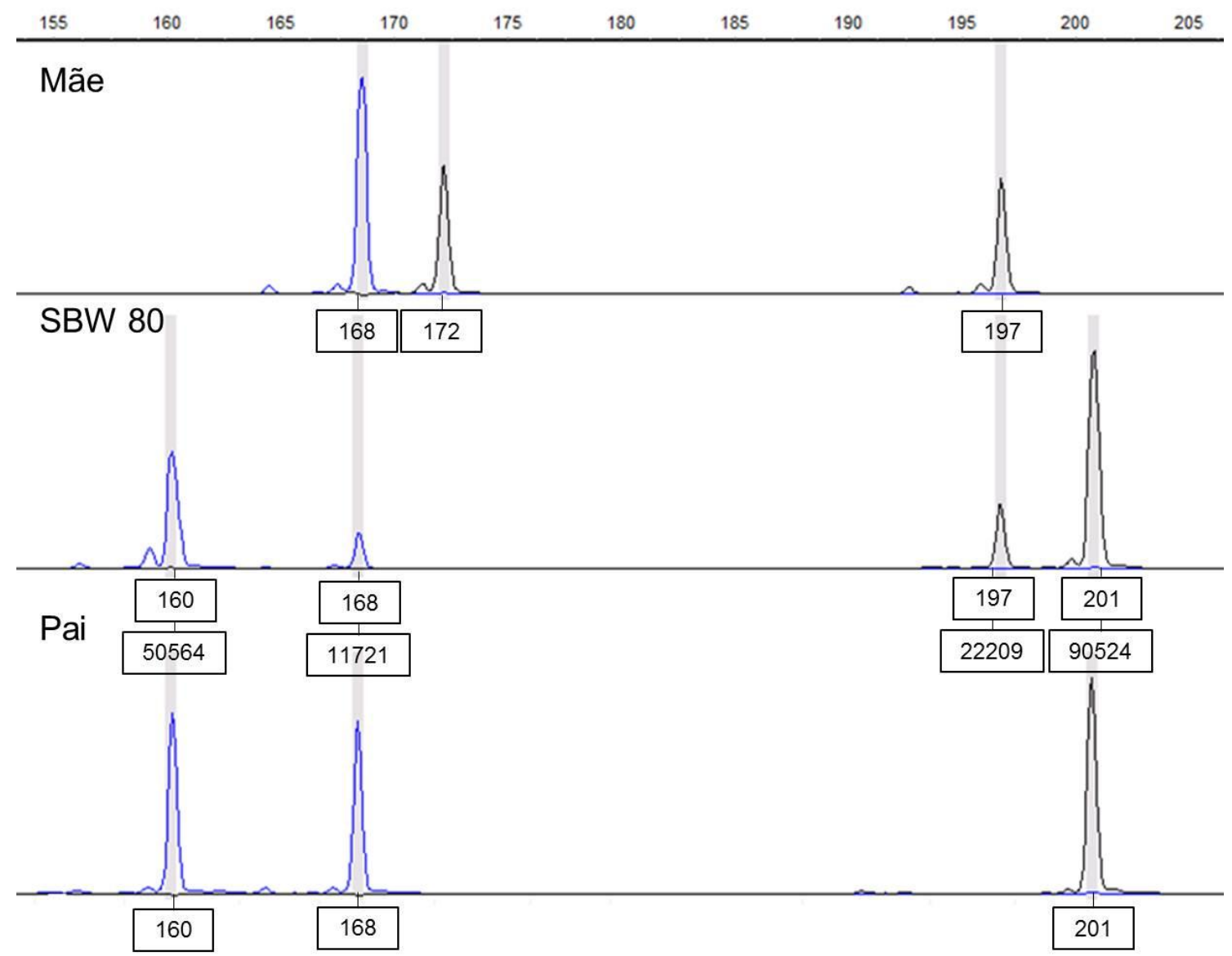

Figura 17. Eletroferograma do perfil genético na dissomia uniparental paterna. A paciente SBW 80 apresentou proporções superiores à $4: 1$ de alelos paternos comparados aos maternos, para os marcadores D11S2479864 (preto) e D11S2703706 (azul). Os alelos estão representados em pares de nucleotídeos e, para a paciente, abaixo dos alelos estão indicadas as áreas dos picos.

Uma família, previamente descrita por Bonaldi e colaboradores (2011), com pacientes SSR devido a uma microduplicação materna na ICR2, foi testada com os marcadores do cromossomo 11. Os irmãos afetados compartilham os mesmos alelos da duplicação materna, enquanto a irmã não afetada herdou o alelo materno diferente (Figura 19). Nenhum outro paciente com SSR apresentou alteração genética detectável. 


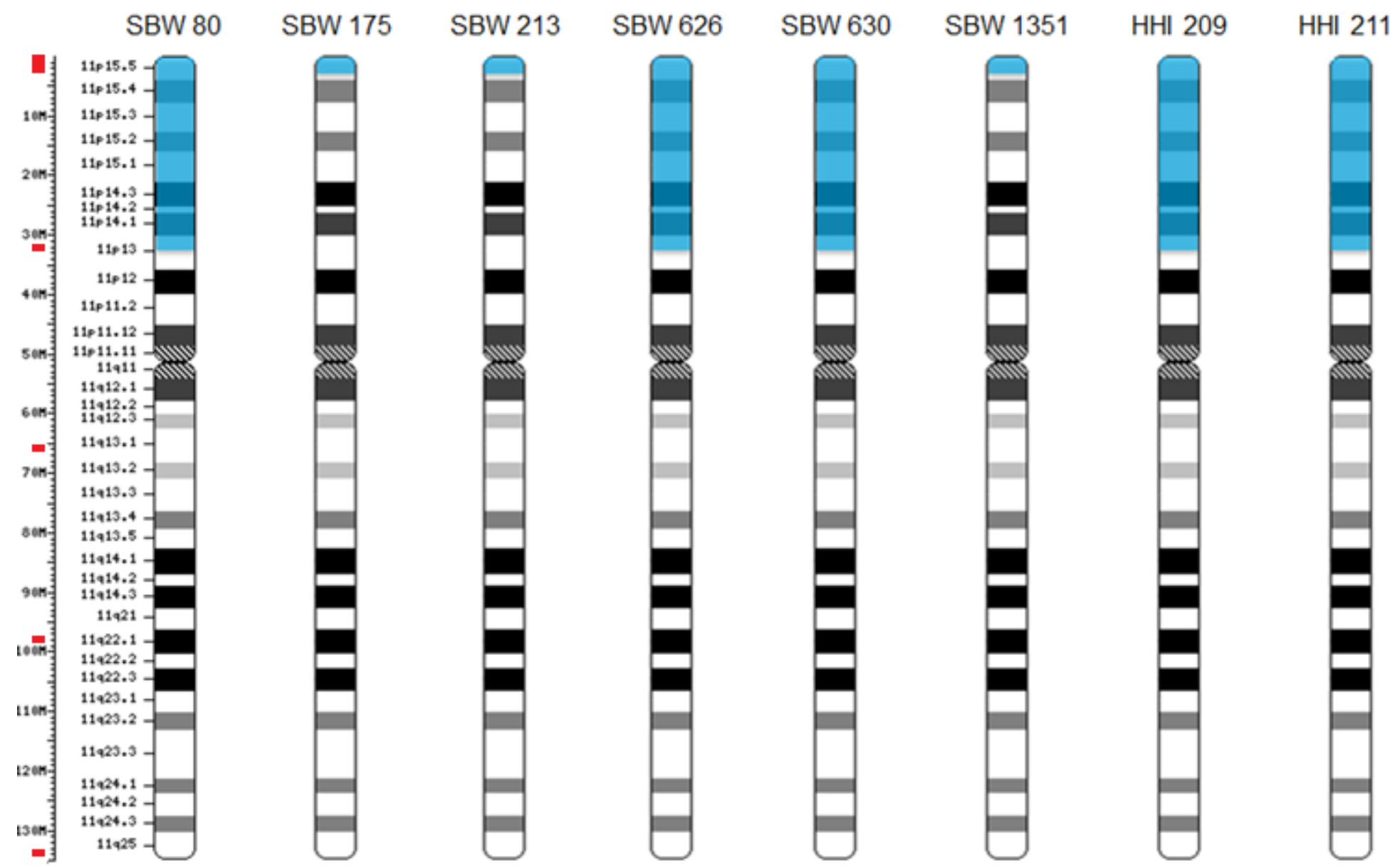

Figura 18. Extensão da dissomia uniparental paterna (DUPpat). A DUPpat foi restrita ao braço curto do cromossomo 11, a sombra em azul mostra a extensão da DUPpat observada nos pacientes com síndrome de Beckwith Wiedemann (SBW) e Hemihiperplasia Isolada (HHI). Em vermelho, a posição física dos marcadores avaliados. 


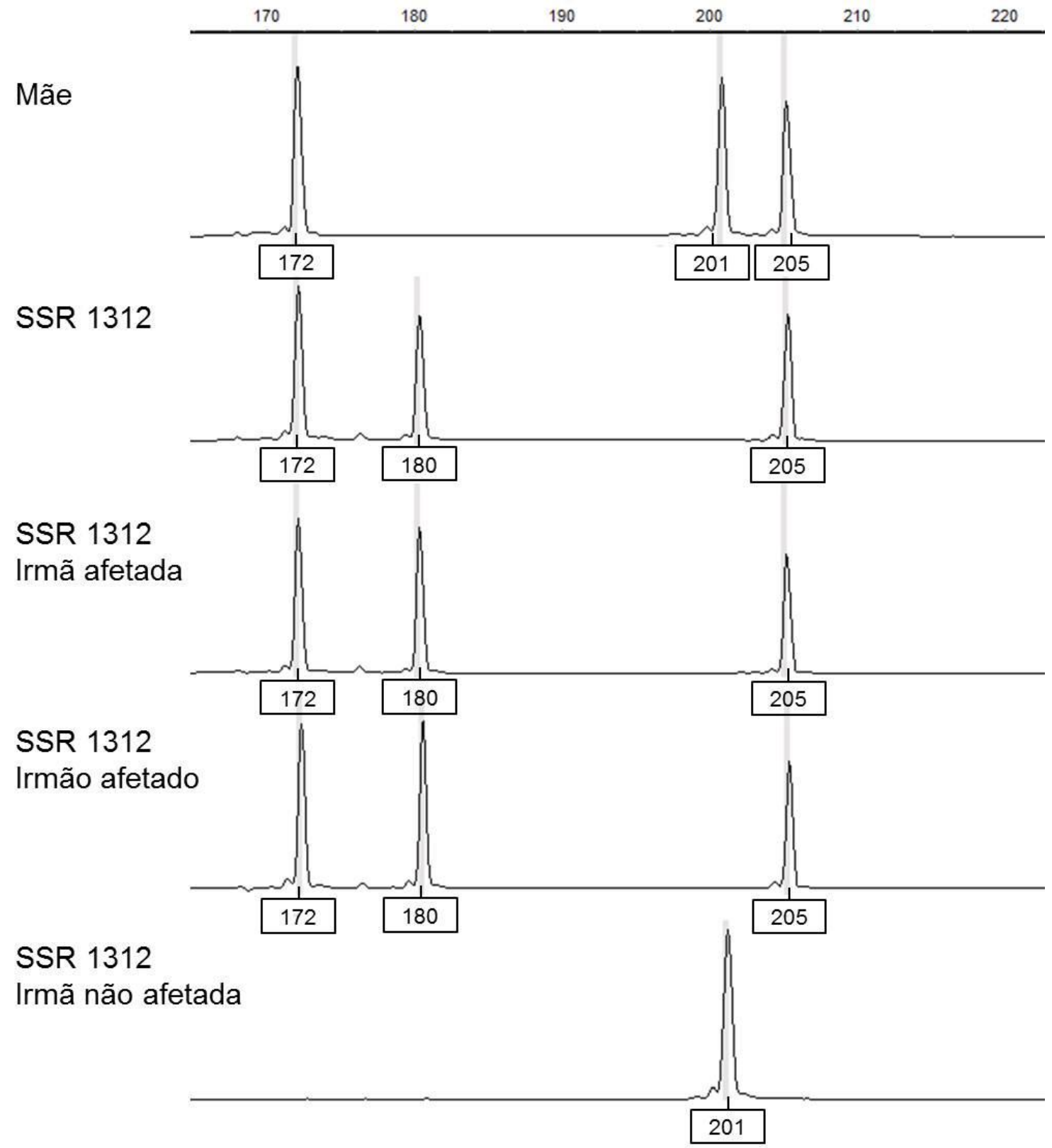

Figura 19. Eletroferograma do marcador D11S2479864 em família com indivíduos afetados pela síndrome de Silver-Russell (SSR). A mãe possui a microduplicação, mas não é afetada. Os irmãos afetados compartilham os mesmos alelos da duplicação materna (172 e 205), a irmã não afetada possui o alelo 201 materno. O marcador D11S2479864 está no íntron 1 do gene KCNQ1. 
O paciente com DMP $X X / X Y$ e seus pais, foram genotipados com seis marcadores microssatélites específicos para 0 cromossomo $X$ e a cópia extra desse cromossomo $\mathrm{X}$ foi confirmada como sendo de origem paterna (Tabela 15). Outros 29 microssatélites distribuídos em 13 autossomos demonstraram a presença de diferentes complementos haplóides paternos, sugerindo evento de dupla fertilização. A figura 20 mostra o perfil genético para três marcadores de diferentes autossomos.

Tabela 15. Marcadores testados no paciente com DMP e seus pais. Alelos representados com as letras $\mathbf{a}, \mathbf{b}, \mathbf{c}$ e $\mathbf{d}$.

\begin{tabular}{|c|c|c|c|c|}
\hline Marcador & Localização & Mãe & Pai & Filho \\
\hline TPOX & $2 \mathrm{p} 25.3$ & $b c$ & ac & $b c^{1}$ \\
\hline D2S1338 & $2 q 35$ & CC & $a b$ & $a b c$ \\
\hline D3S1358 & $3 p 21.31$ & $\mathrm{bb}$ & $a b$ & $\mathrm{bb}$ \\
\hline FGA & $4 q 31.3$ & ad & $\mathrm{bc}$ & $a b c$ \\
\hline D5S818 & $5 q 23.2$ & $a b$ & aa & aa \\
\hline CSF1PO & $5 q 32$ & $a b$ & $\mathrm{bb}$ & $\mathrm{bb}$ \\
\hline D7S820 & $7 q 21.11$ & ac & $a b$ & $a b$ \\
\hline D8S1179 & $8 q 24.13$ & $a b$ & bc & $a b c$ \\
\hline TH01 & $11 \mathrm{p} 15.5$ & $a b$ & ac & $a b c$ \\
\hline vWA & $12 p 13.31$ & aa & $a b$ & $a b$ \\
\hline D13S742 & $13 q 12.12$ & $a b$ & ac & $a b$ \\
\hline D13S252 & $13 q 12.2$ & aa & bc & $a b c$ \\
\hline D13S305 & $13 q 13.3$ & $a b$ & $\mathrm{bc}$ & $a b c$ \\
\hline D13S634 & $13 q 21.33$ & ac & $a b$ & ac \\
\hline D13S317 & $13 q 31.1$ & ac & $\mathrm{bc}$ & $a b$ \\
\hline D13S628 & $13 q 31.1$ & $a b$ & ac & $a b$ \\
\hline D13S762 & $13 q 31.3$ & $a b$ & $a b$ & $\mathrm{bb}$ \\
\hline D16S539 & $16 q 24.1$ & aa & $\mathrm{bb}$ & $a b$ \\
\hline D18S391 & $18 p 11.31$ & $a b$ & bc & ac \\
\hline D18S1002 & $18 q 11.2$ & aa & bc & ac \\
\hline D18S535 & $18 q 12.3$ & ac & bc & ac \\
\hline D18S978 & $18 q 12.3$ & $a b$ & $a b$ & $a b$ \\
\hline D18S499 & $18 q 21.32$ & $a b$ & $a b$ & $a b$ \\
\hline D18S51 & $18 q 21.33$ & ad & bc & bd \\
\hline D18S386 & $18 q 22.1$ & $a b$ & $c d$ & ac \\
\hline D19S433 & $19 q 12$ & $a b$ & $a b$ & $a b$ \\
\hline D21S11 & $21 q 21.1$ & ad & bc & acd \\
\hline D21S2039 & 21q22.11 & $\mathrm{bb}$ & ac & $a b$ \\
\hline D21S1411 & $21 q 22.3$ & $a b$ & ac & aa \\
\hline DXS996 & Xp22.3 & $a b$ & a & aa \\
\hline DXS1283E & Xp22.3 & $a b$ & c & ac \\
\hline DXS981 & Xq13.1 & $a b$ & $b$ & $\mathrm{bb}$ \\
\hline DXS1187 & Xq26.2 & $a b$ & a & aa \\
\hline HPRT & Xq26.3 & aa & $b$ & $a b$ \\
\hline P39 & Xq28 & $a b$ & c & ac \\
\hline$X 22$ & Xqter/Yqter & bd & ac & $a b c$ \\
\hline
\end{tabular}


D18S386 (18q22.1)

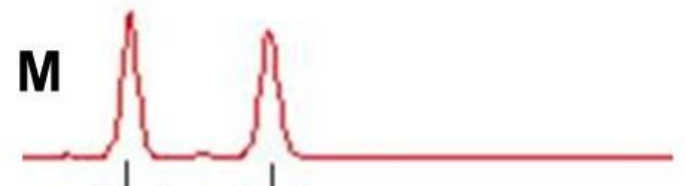

a b

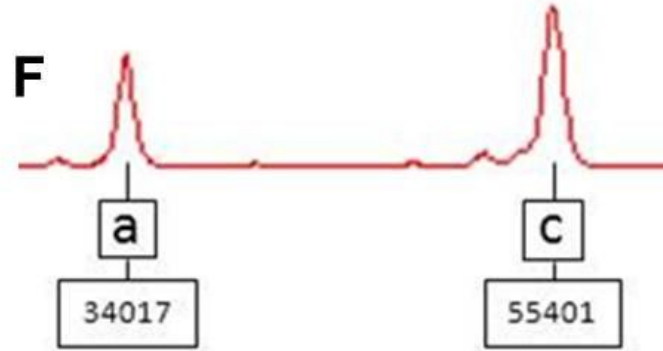

$\mathbf{P}$

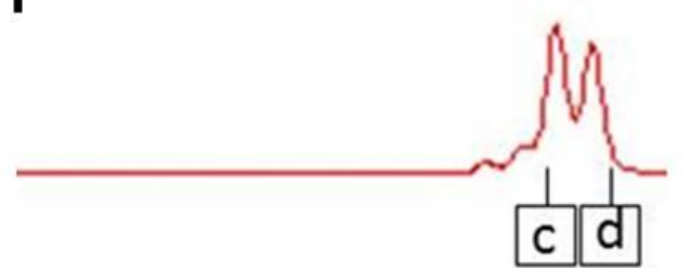

D21S11 (21q21.1)
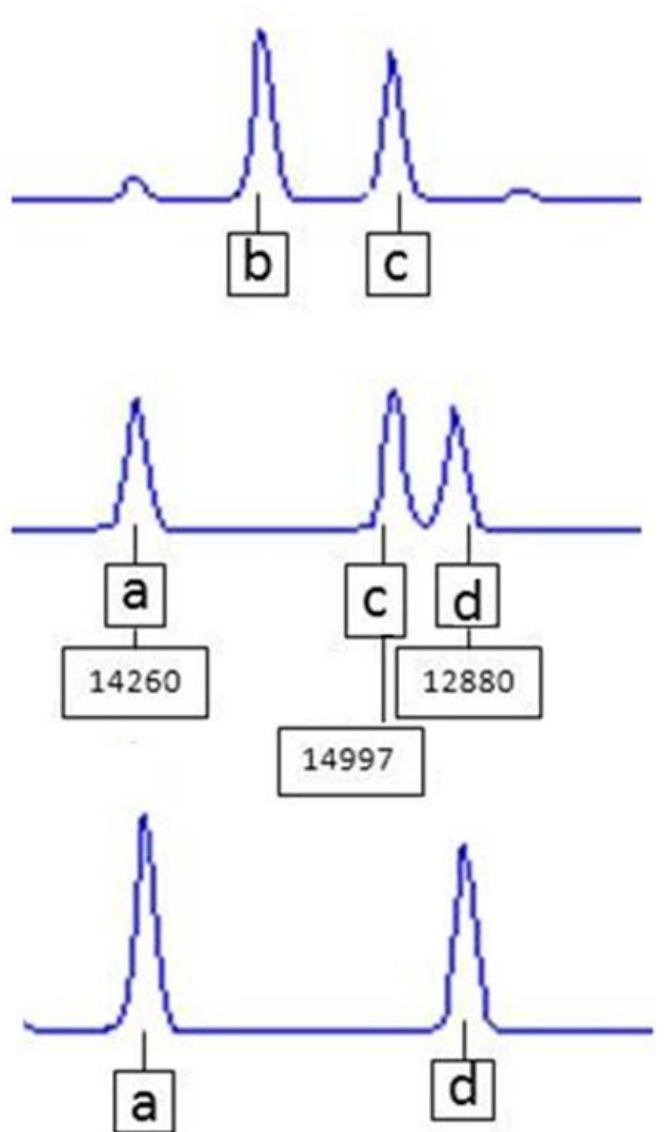

TH01 (11p15.5)

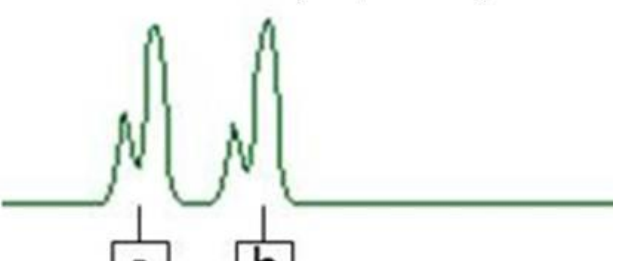

a b
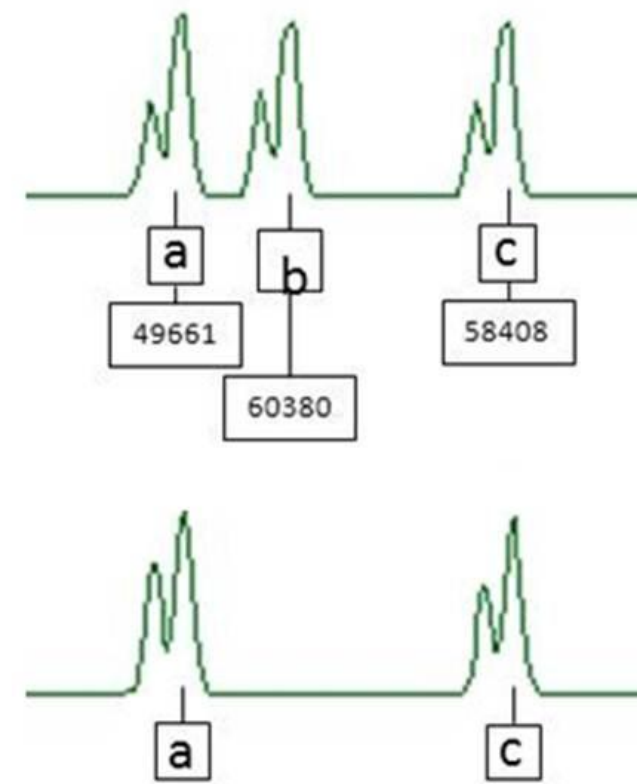

Figura 20. Eletroferograma dos perfis genéticos para os marcadores D18S386, D21S11 e TH01 em núcleo familiar. O filho 46XX/46XY (F) possui duas cópias de alelos paternos $(P)$ para todos os marcadores investigados, e uma cópia de alelos maternos (M). Por ser um indivíduo $2 n$, o excesso de componente genético paterno indica a presença de células androgenéticas. Os alelos estão representados por letras e abaixo dos alelos estão indicadas as áreas dos picos. Os pais (M e P) apresentaram alelos com proporções aproximadas de 1:1. 


\subsection{MS-MLPA}

Para verificar alterações (epi) genéticas em 11p15.5, 31 pacientes com SBW, 16 com HHI, 19 com SSR e sete indivíduos hígidos (controles) foram avaliados por meio do ensaio MS-MLPA. Nenhum indivíduo controle apresentou alguma alteração (epi) genética. Foi realizada replicata (em dia diferente) para 15 pacientes e os resultados foram concordantes. A figura 21 mostra um eletroferograma dos dados brutos do ensaio MS-MLPA.

Entre os pacientes com SBW, 74\% apresentou alteração genética e/ou epigenética na região investigada (Tabela 16). A principal alteração epigenética observada foi a hipometilação na KvDMR1 (ICR2). Os pacientes com DUPpat apresentaram alteração epigenética em ambas ICRs, e a presença de de DUPpat foi diretamente proporcional à alteração epigenética. Ou seja, quanto maior foi o número de células com DUPpat, mais expressivo os valores encontrados de hipermetilação na H19DMR (ICR1) e de hipometilação na KvDMR1 (ICR2).

O gráfico 1 mostra o resultado de um paciente (SBW 1313) sem alteração estrutural da região 11 15.5. O gráfico 2 mostra o resultado do paciente SBW 228 que apresentou duplicação paterna em 11p15.5.

A paciente SBW 744 apresentou deleção no gene CDKN1C (gráfico 3). Para caracterização da mutação como sendo herdada ou de novo, os pais foram investigados. A mãe da paciente apresentou a mesma mutação observada na filha (gráfico 4). A probanda apresentou perfil de metilação normal nas ICRs (gráfico 5).

O gráfico 6 mostra o perfil alterado de metilação na ICR2 em paciente sem alteração estrutural detectável e o gráfico 7 mostra o perfil alterado de metilação na ICR1. O resultado de uma paciente com DUPpat é mostrado no gráfico 8, evidenciando a alteração epigenética em ambas ICRs.

Entre os pacientes com $\mathrm{HHI}$, apenas dois apresentaram alterações epigenéticas devido à presença de DUPpat (Tabela 17). O paciente HHI 209 apresentou DUPpat completa para marcadores microssatélites em 11p15.5, que refletiu nos resultados observados do perfil de metilação nas ICRs 1 e 2 . O perfil de metilação observado para a ICR1 foi próximo de 100\% e para ICR2, próximo a zero (gráfico 9). 
A alteração genética observada em pacientes com SSR se restringiu à família previamente descrita por Bonaldi e colaboradores (2011) (Tabela 18).

A duplicação de origem materna na ICR2 (gráfico 10) gerou a hipermetilação observada desta região (gráfico 11). Entre os pacientes sem alteração estrutural observável, 25\% apresentou hipometilação na ICR1. O gráfico 12 mostra um exemplo de alteração epigenética na ICR1.

Tabela 16. Alterações (epi) genéticas observadas em pacientes com síndrome de BeckwithWiedemann (SBW), por meio do ensaio MS-MLPA. ICR: Região Controladora de Imprinting. DUPpat: Dissomia Uniparental Paterna. $\left(^{\star}\right)$ Determinada por microssatélites.

\begin{tabular}{|c|c|c|c|c|c|}
\hline & Paciente & $\begin{array}{l}\text { Alteração } \\
\text { genética* }\end{array}$ & $\begin{array}{c}\text { Alteração } \\
\text { genética }\end{array}$ & ICR1 & ICR2 \\
\hline 1 & SBW 48 & & & Normal & Hipometilação \\
\hline 2 & SBW 80 & DUPpat & & Hipermetilação & Hipometilação \\
\hline 3 & SBW 129 & & & Hipermetilação & Normal \\
\hline 4 & SBW 130 & & & Normal & Hipometilação \\
\hline 5 & SBW 131 & & & Normal & Hipometilação \\
\hline 6 & SBW 136 & & & Normal & Hipometilação \\
\hline 7 & SBW 160 & & & Normal & Hipometilação \\
\hline 8 & SBW 170 & & & Normal & Hipometilação \\
\hline 9 & SBW 171 & & & Normal & Hipometilação \\
\hline 10 & SBW 174 & & & Normal & Hipometilação \\
\hline 11 & SBW 175 & DUPpat & & Hipermetilação & Hipometilação \\
\hline 12 & SBW 212 & & & Normal & Hipometilação \\
\hline 13 & SBW 213 & DUPpat & & Hipermetilação & Hipometilação \\
\hline 14 & SBW 228 & Duplicação pat & Duplicação & Hipermetilação & Hipometilação \\
\hline 15 & SBW 626 & DUPpat & & Hipermetilação & Hipometilação \\
\hline 16 & SBW 628 & & & Normal & Hipometilação \\
\hline 17 & SBW 629 & & & Normal & Hipometilação \\
\hline 18 & SBW630 & DUPpat & & Hipermetilação & Hipometilação \\
\hline 19 & SBW 744 & & Deleção CDKN1C & Normal & Normal \\
\hline 20 & SBW 745 & & & Normal & Normal \\
\hline 21 & SBW 746 & & & Normal & Hipometilação \\
\hline 22 & SBW 1010 & & & Normal & Normal \\
\hline 23 & SBW1012 & & & Normal & Normal \\
\hline 24 & SBW 1013 & & & Normal & Hipometilação \\
\hline 25 & SBW 1015 & & & Hipermetilação & Normal \\
\hline 26 & SBW 1307 & & & Normal & Normal \\
\hline 27 & SBW 1313 & & & Normal & Normal \\
\hline 28 & SBW 1351 & DUPpat & & Hipermetilação & Hipometilação \\
\hline 29 & SBW 1507 & & & Normal & Normal \\
\hline 30 & SBW 1601 & & & Normal & Normal \\
\hline 31 & SBW 1613 & & & Normal & Normal \\
\hline
\end{tabular}


Tabela 17. Alterações (epi)genéticas observadas em pacientes com Hemihiperplasia Isolada (HHI), por meio do ensaio MS-MLPA. ICR: Região Controladora de Imprinting. DUPpat: Dissomia Uniparental Paterna. (*) Determinada por microssatélites.

\begin{tabular}{|c|l|c|c|c|}
\cline { 2 - 5 } \multicolumn{1}{c|}{} & Paciente & $\begin{array}{c}\text { Alteração } \\
\text { genética* }\end{array}$ & ICR1 & ICR2 \\
\hline 1 & $\mathrm{HHI} 33$ & & Normal & Normal \\
\hline 2 & $\mathrm{HHI} 101$ & & Normal & Normal \\
\hline 3 & $\mathrm{HHI} 134$ & & Normal & Normal \\
\hline 4 & $\mathrm{HHI} 209$ & DUPpat & Hipermetilação & Hipometilação \\
\hline 5 & $\mathrm{HHI} 210$ & & Normal & Normal \\
\hline 6 & $\mathrm{HHI} 211$ & DUPpat & Hipermetilação & Hipometilação \\
\hline 7 & $\mathrm{HHI} 400$ & & Normal & Normal \\
\hline 8 & $\mathrm{HHI} 402$ & & Normal & Normal \\
\hline 9 & $\mathrm{HHI} 627$ & & Normal & Normal \\
\hline 10 & $\mathrm{HHI} 747$ & & Normal & Normal \\
\hline 11 & $\mathrm{HHI} 1109$ & & Normal & Normal \\
\hline 12 & $\mathrm{HHI} 1532$ & & Normal & Normal \\
\hline 13 & $\mathrm{HHI} 1622$ & & Normal & Normal \\
\hline 14 & $\mathrm{HHI} 1635$ & & Normal & Normal \\
\hline 15 & $\mathrm{HHI} 1642$ & & Normal & Normal \\
\hline 16 & $\mathrm{HHI} 1551$ & & Normal & Normal \\
\hline
\end{tabular}

Tabela 18. Alterações (epi)genéticas observadas em pacientes com síndrome de SilverRussell (SSR), por meio do ensaio MS-MLPA. ICR: Região Controladora de Imprinting. DUPpat: Dissomia Uniparental Paterna. (¥) Determinada por microssatélites e MS-MLPA.

\begin{tabular}{|c|c|c|c|c|}
\hline & Paciente & Alteração genética & ICR1 & ICR2 \\
\hline 1 & SSR 1003 & & Normal & Normal \\
\hline 2 & SSR 1006 & & Hipometilação & Normal \\
\hline 3 & SSR 1007 & & Normal & Normal \\
\hline 4 & SSR 1108 & & Normal & Normal \\
\hline 5 & SSR 1312 & Duplicação mat ICR2 & Normal & Hipermetilação \\
\hline 6 & SSR 1314 & Duplicação mat ICR2 & Normal & Hipermetilação \\
\hline 7 & SSR 1315 & Duplicação mat ICR2 & Normal & Hipermetilação \\
\hline 8 & SSR 1356 & & Normal & Normal \\
\hline 9 & SSR 1368 & & Hipometilação & Normal \\
\hline 10 & SSR 1374 & & Normal & Normal \\
\hline 11 & SSR 1376 & & Normal & Normal \\
\hline 12 & SSR 1377 & & Normal & Normal \\
\hline 13 & SSR 1378 & & Normal & Normal \\
\hline 14 & SSR 1379 & & Hipometilação & Normal \\
\hline 15 & SSR 1380 & & Hipometilação & Normal \\
\hline 16 & SSR 1381 & & Normal & Normal \\
\hline 17 & SSR 1397 & & Normal & Normal \\
\hline 18 & SSR 1525 & & Normal & Normal \\
\hline 19 & SSR 1529 & & Normal & Normal \\
\hline
\end{tabular}




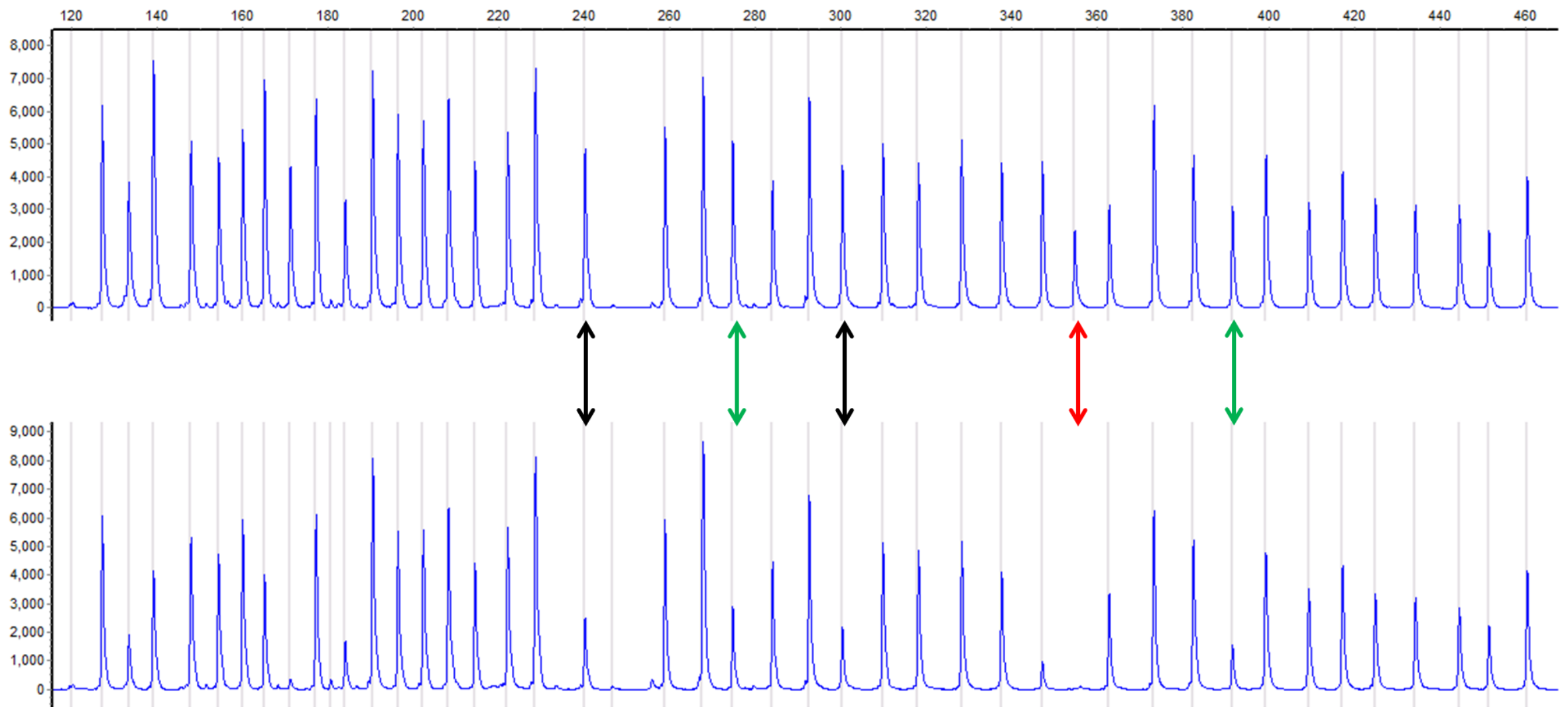

Figura 21. Eletroferograma do ensaio MS-MLPA para região 11p15.5. Dados brutos do ensaio MS-MLPA em um indivíduo saudável. O painel superior mostra o perfil de amplificação das 42 sondas antes da digestão com a enzima Hhal, o painel inferior mostra o perfil após a digestão. As setas pretas exemplificam duas sondas na ICR1, as verdes exemplificam duas sondas na ICR2 e a seta vermelha mostra a sonda controle para digestão total. Note a diminuição do sinal de aproximadamente $50 \%$ para as sondas nas ICRs 1 e 2 , e de $100 \%$ para a sonda controle. Eixo y em unidades relativas de fluorescência. 


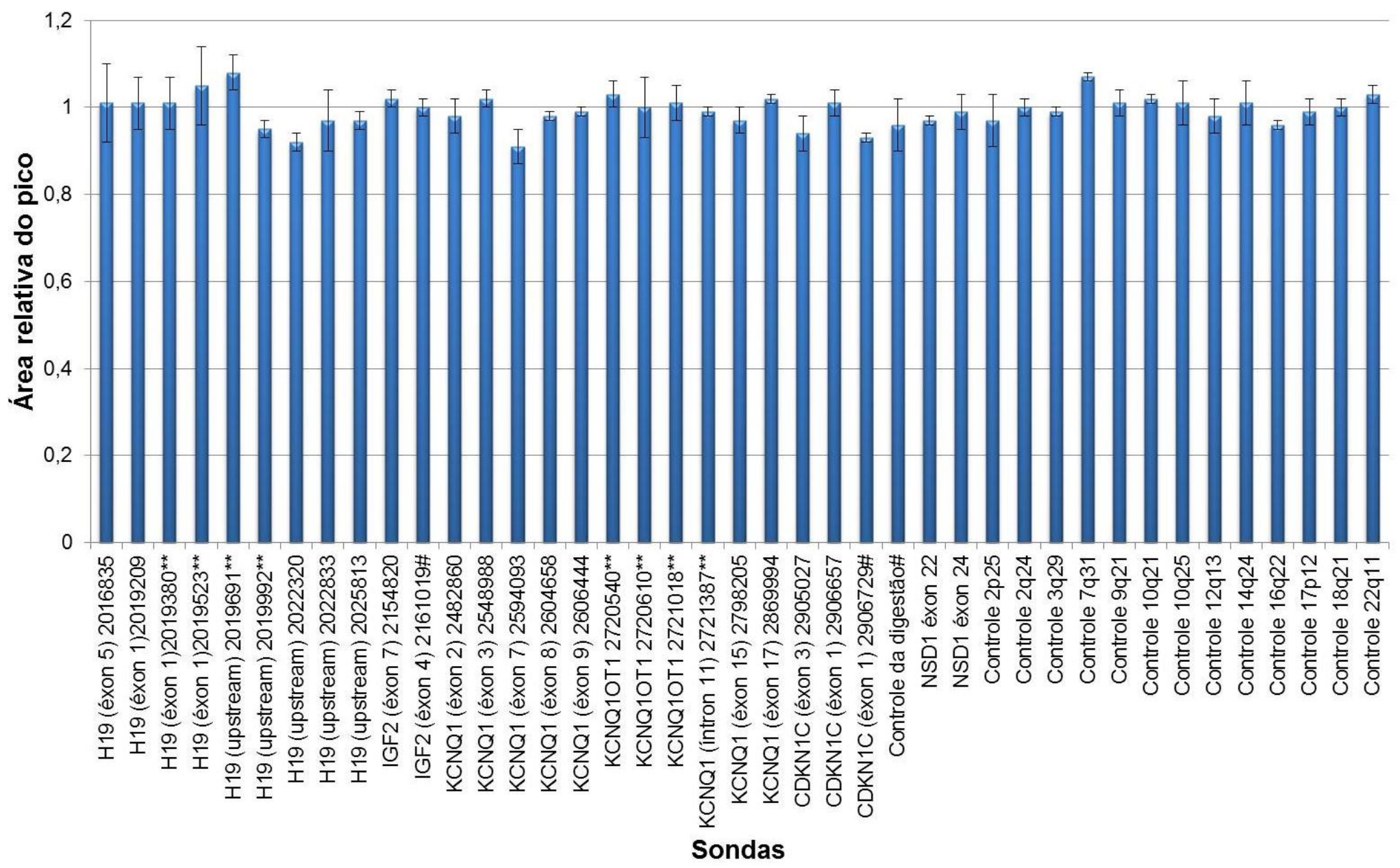

Gráfico 1. Perfil quantitativo da região 11 p15.5 em paciente sem alteração estrutural. Resultado do ensaio MS-MLPA para o paciente SBW 1313 mostrando a ausência de alteração estrutural. No eixo y, as áreas relativas dos picos estão entre 0,75 e 1,25. Eixo x: sondas para região 11 p15.5 e sondas-controle. Mais informações sobre as sondas na tabela 5. 


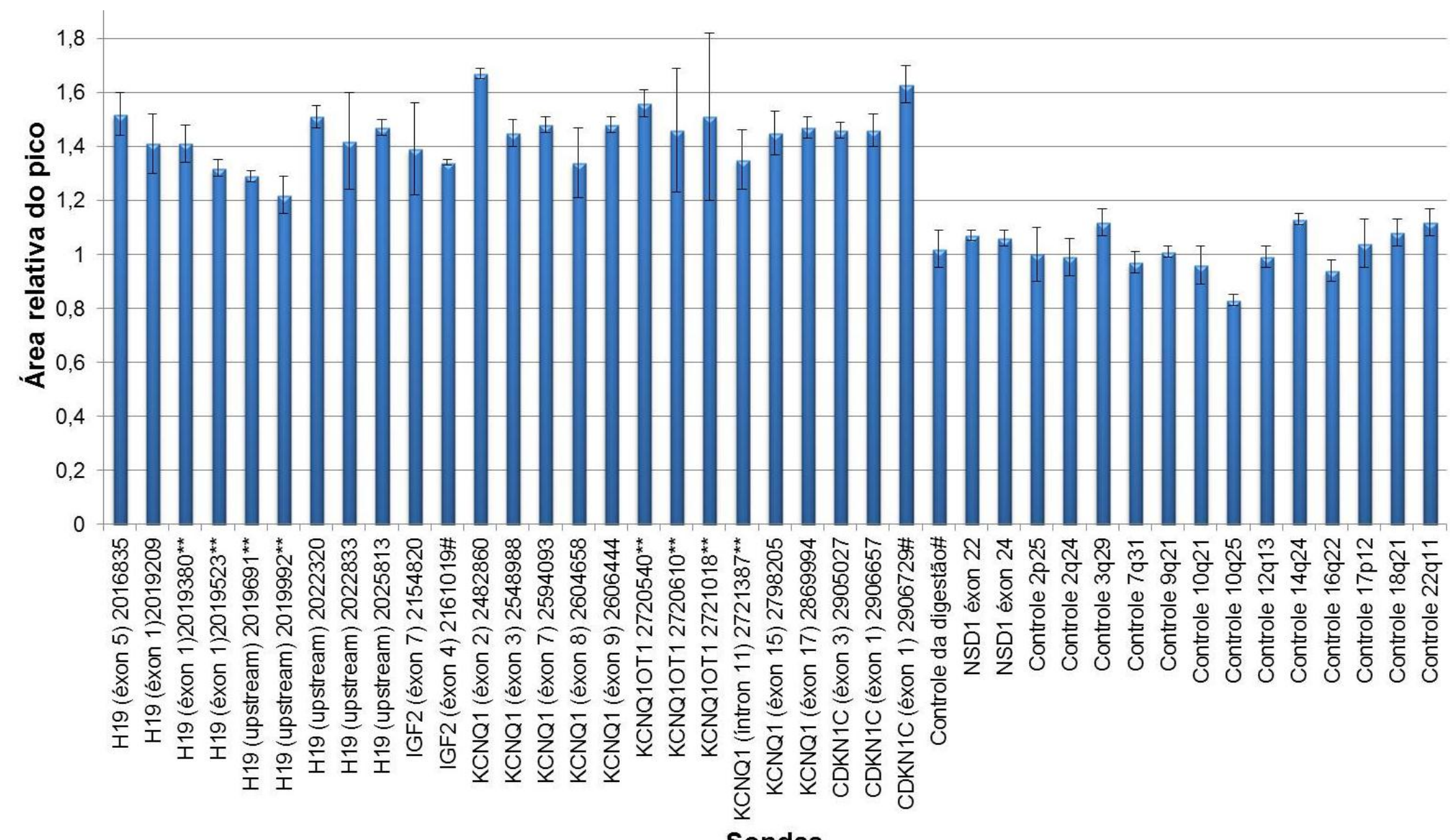

Gráfico 2. Perfil quantitativo da região 11 p15.5 em paciente com duplicação paterna. Resultado do ensaio MS-MLPA para o paciente SBW 228 mostrando aumento na área relativa dos picos (eixo y) com valores acima de 1,25 na região 11p15.5 e valores normais (entre 0,75 e 1,25) para as sondas-controle. Eixo x: sondas para região 11 p15.5 e sondas controle. Mais informações sobre as sondas na tabela 5. 


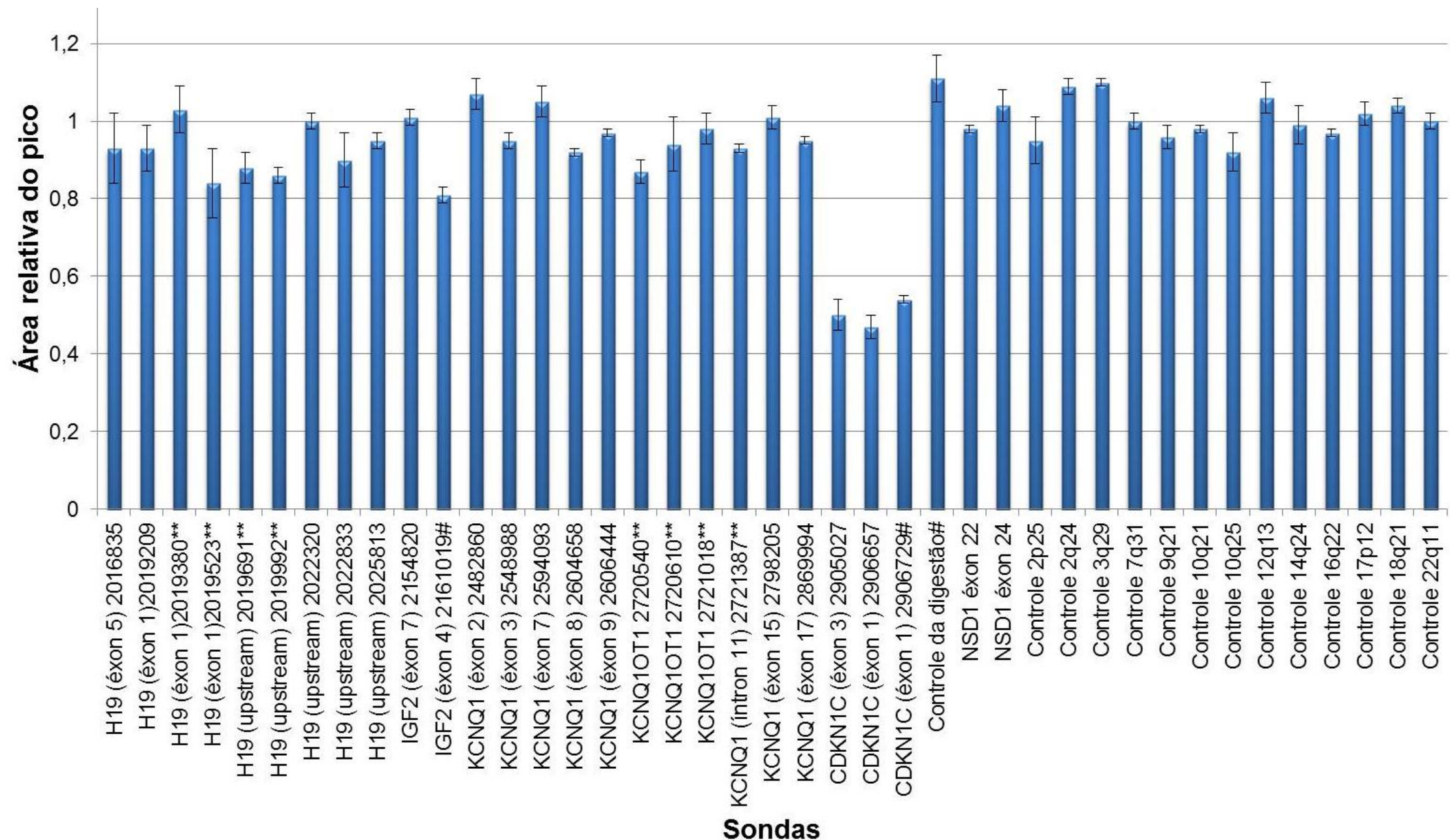

Gráfico 3. Perfil quantitativo da região 11 p15.5 em paciente com deleção gênica. Resultado do ensaio MS-MLPA para a paciente SBW 744 mostrando diminuição na área relativa dos picos (eixo y) com valores abaixo de 1,25 no gene CDKN1C e valores normais (entre 0,75 e 1,25) para as demais sondas. Eixo x: sondas para região 11 p15.5 e sondas-controle. Mais informações sobre as sondas na tabela 5. 


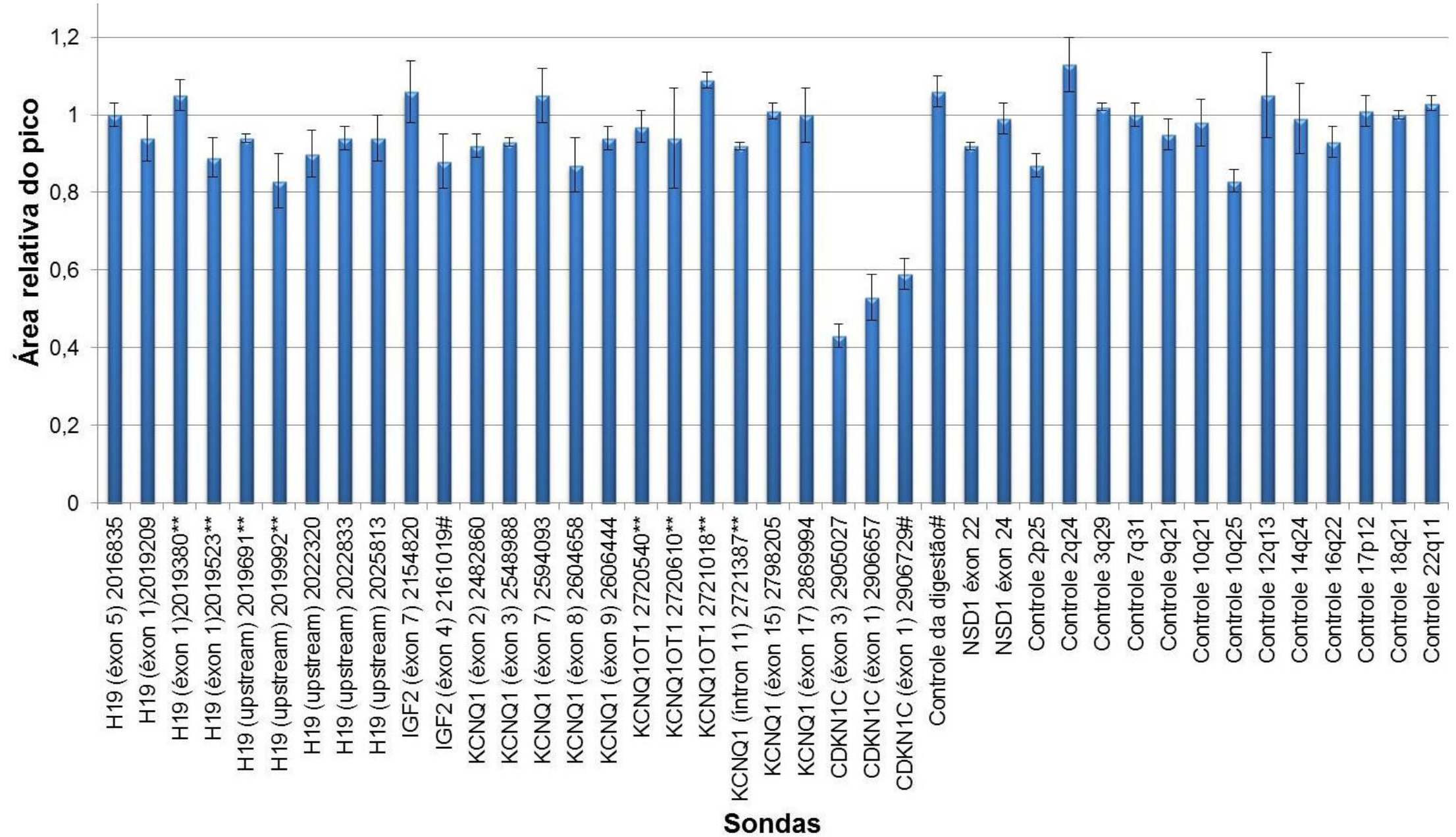

Gráfico 4. Perfil quantitativo da região 11p15.5 em mãe de paciente com deleção gênica. Resultado do ensaio MS-MLPA para a paciente SBW 744 mostrando diminuição na área relativa dos picos (eixo y) com valores abaixo de 1,25 no gene CDKN1C e valores normais (entre 0,75 e $1,25)$ para as demais sondas. Eixo x: sondas para região 11 p15.5 e sondas-controle. Mais informações sobre as sondas na tabela 5. 


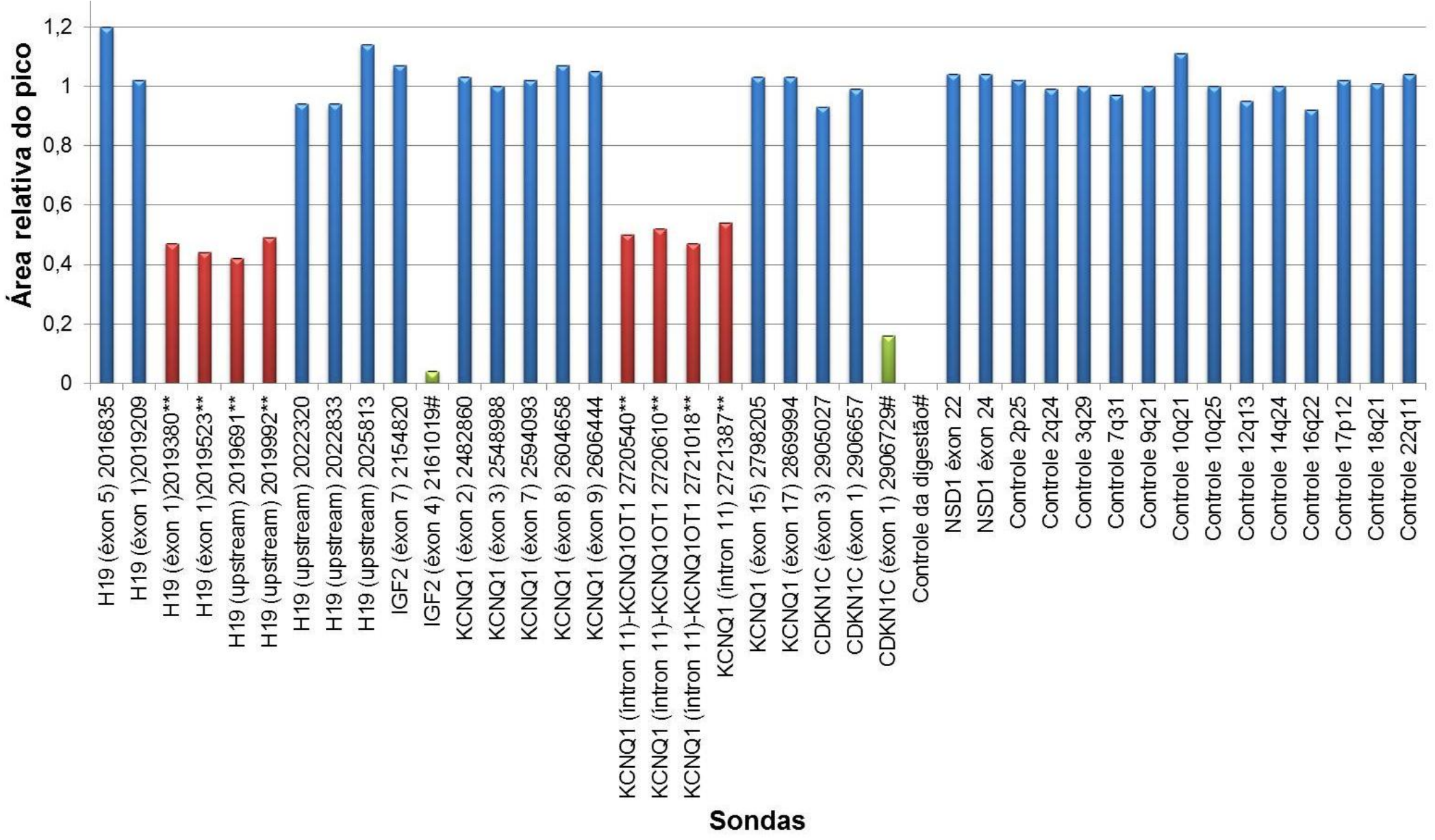

Gráfico 5. Perfil epigenético das ICRs 1 e 2 em paciente com metilação normal. Resultado do ensaio MS-MLPA para a paciente SBW 744 que apresentou deleção no gene CDKN1C, mostrando perfil epigenético normal na ICR1 (lado esquerdo em vermelho) e ICR2 (centro em vermelho). O controle da digestão mostra a ausência de pico. Em verde, o perfil de metilação para os genes IGF2 e CDKN1C. Eixo x: sondas para região 11 p15.5 e sondas-controle. Mais informações sobre as sondas na tabela 5. 


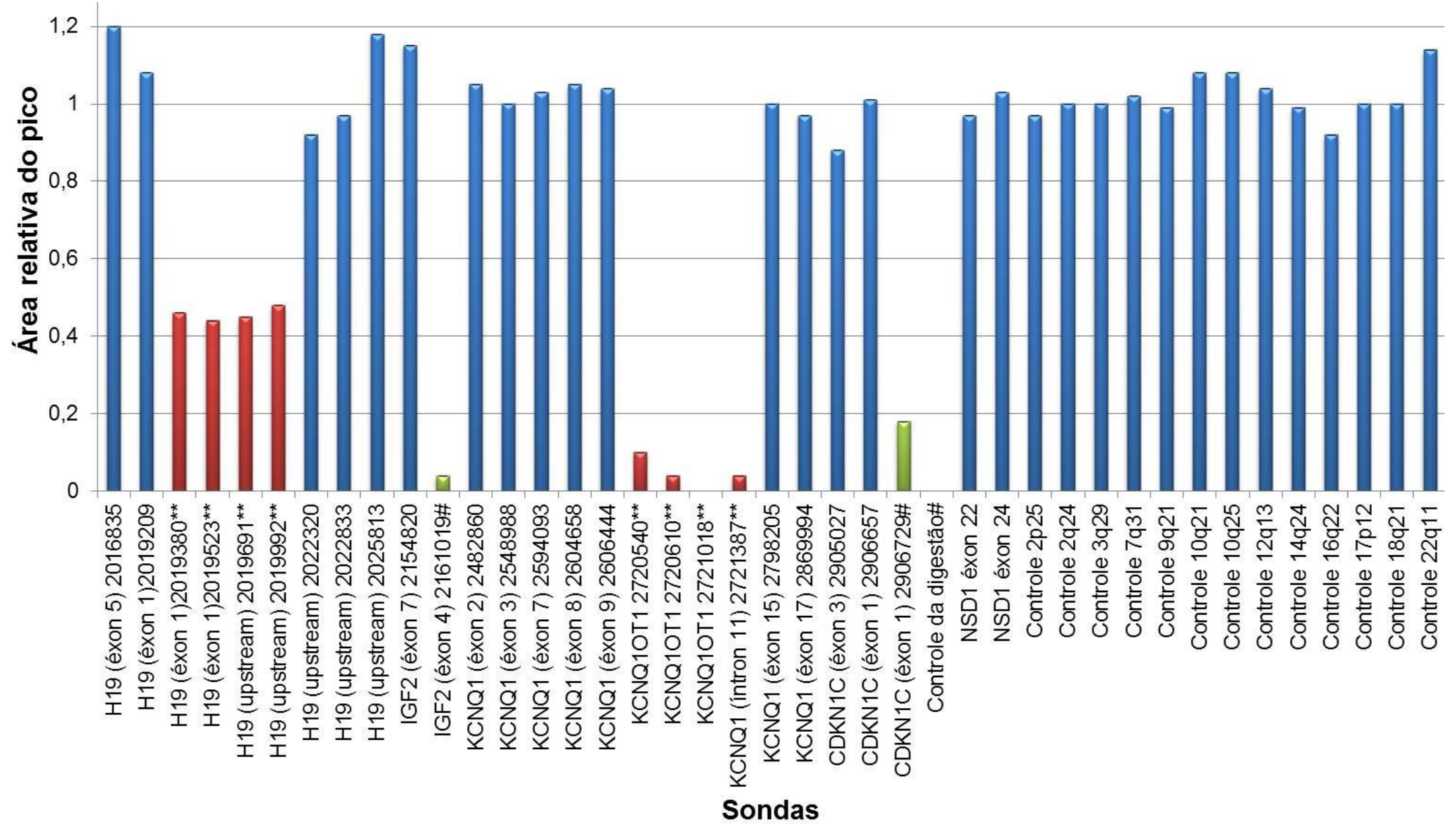

Gráfico 6. Perfil epigenético das ICRs 1 e 2 em paciente com hipometilação da ICR2. Resultado do ensaio MS-MLPA para a paciente SBW 136 mostrando perfil epigenético normal na ICR1 (lado esquerdo em vermelho) e hipometilação na ICR2 (centro em vermelho). O controle da digestão mostra a ausência de pico. Em verde, o perfil de metilação para os genes IGF2 e CDKN1C. Eixo x: sondas para região 11 p15.5 e sondas- controle. Mais informações sobre as sondas na tabela 5. 


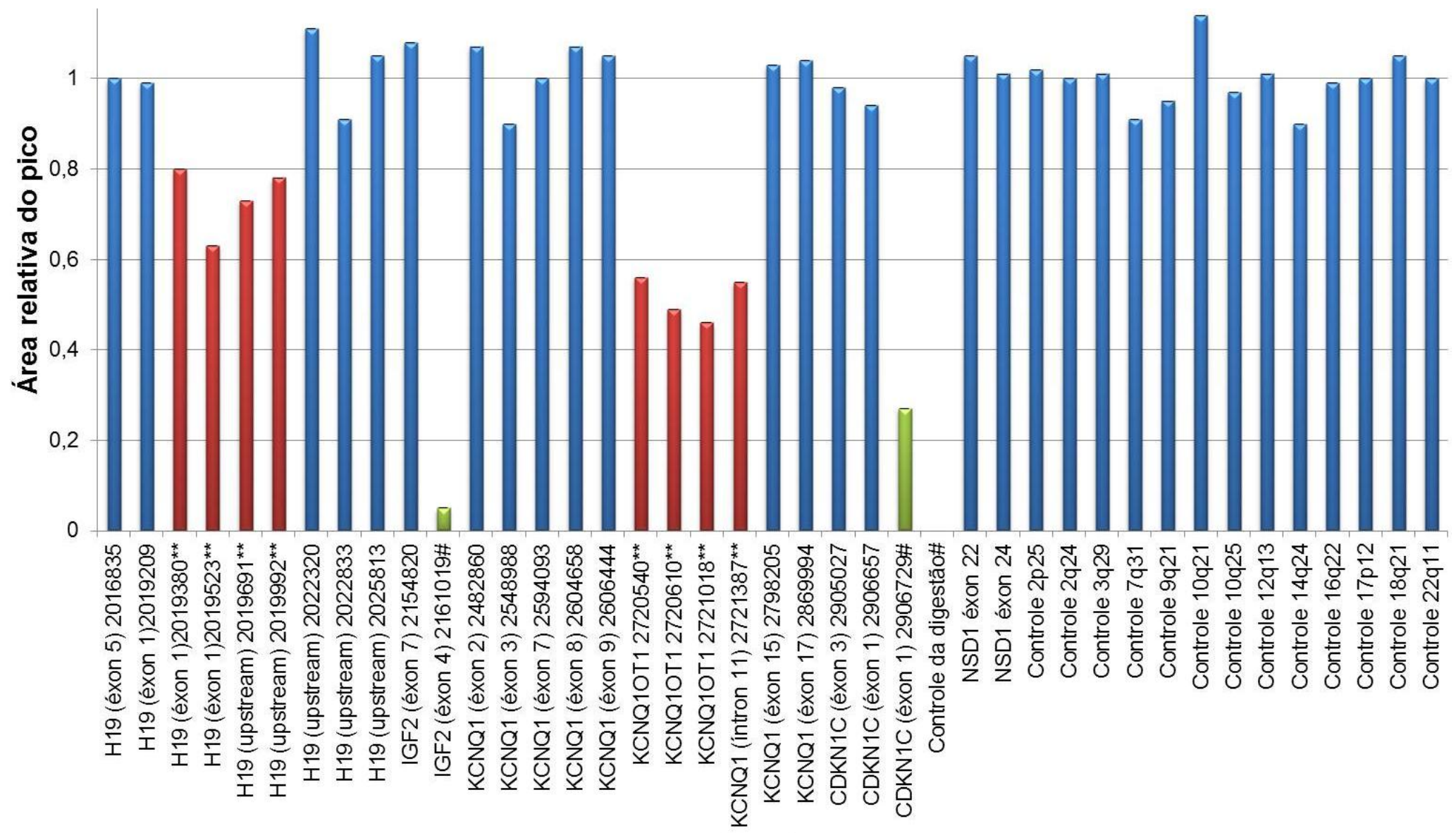

Sondas

Gráfico 7. Perfil epigenético das ICRs 1 e 2 em paciente com hipermetilação da ICR1. Resultado do ensaio MS-MLPA para o paciente SBW 1015 mostrando perfil epigenético normal na ICR2 (centro em vermelho) e hipermetilação na ICR1 (lado esquerdo em vermelho). O controle da digestão mostra a ausência de pico. Em verde, o perfil de metilação para os genes IGF2 e CDKN1C. Eixo x: sondas para região 11 p15.5 e sondas-controle. Mais informações sobre as sondas na tabela 5. 


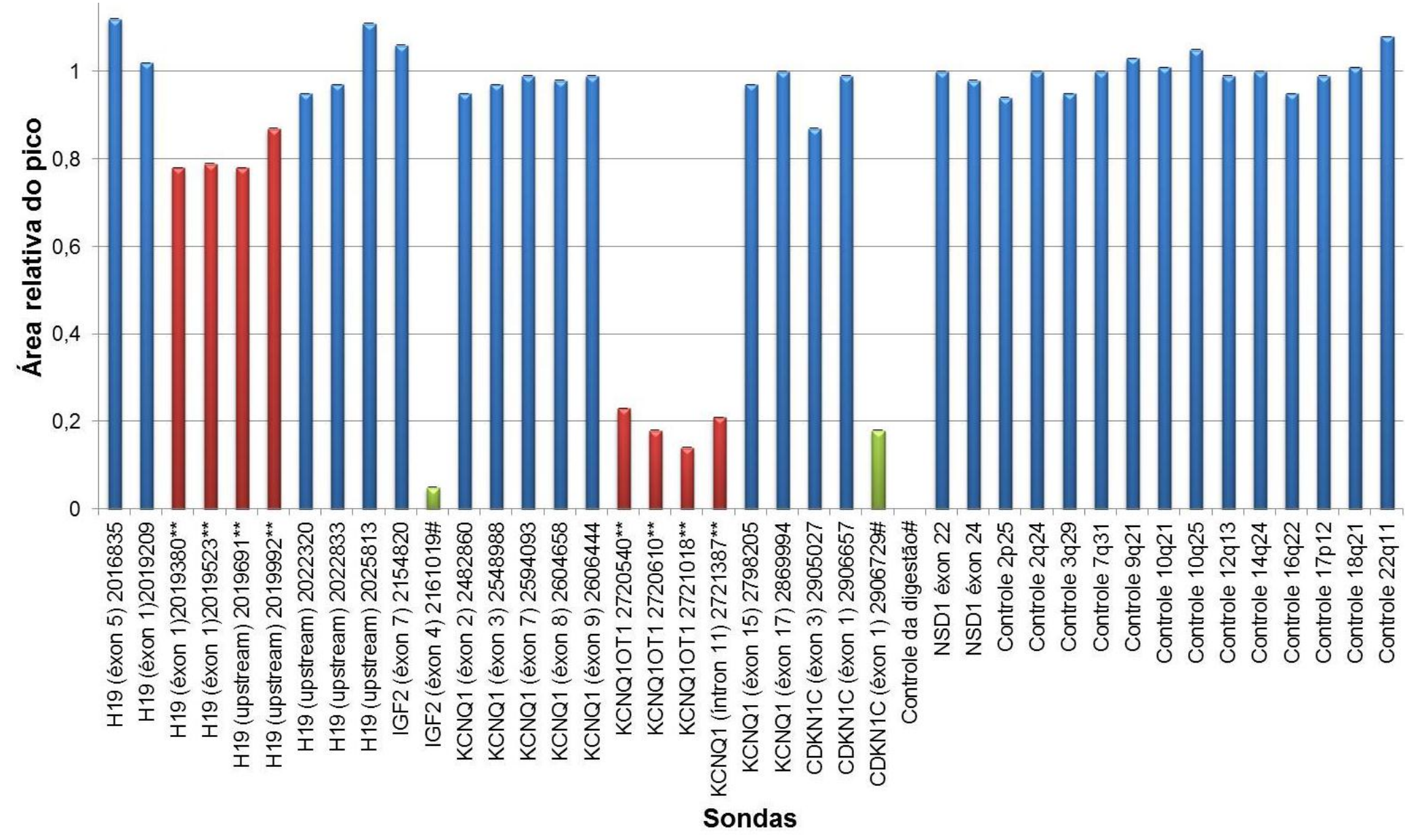

Gráfico 8. Perfil epigenético das ICRs 1 e 2 em paciente com dissomia uniparental paterna. Resultado do ensaio MS-MLPA para paciente SBW 80 mostrando perfil epigenético de hipermetilação na ICR1 (lado esquerdo em vermelho) e hipometilação na ICR2 (centro em vermelho). O controle da digestão mostra a ausência de pico. Em verde, o perfil de metilação para os genes IGF2 e CDKN1C. Eixo x: sondas para região 11 p15.5 e sondas-controle. Mais informações sobre as sondas na tabela 5. 


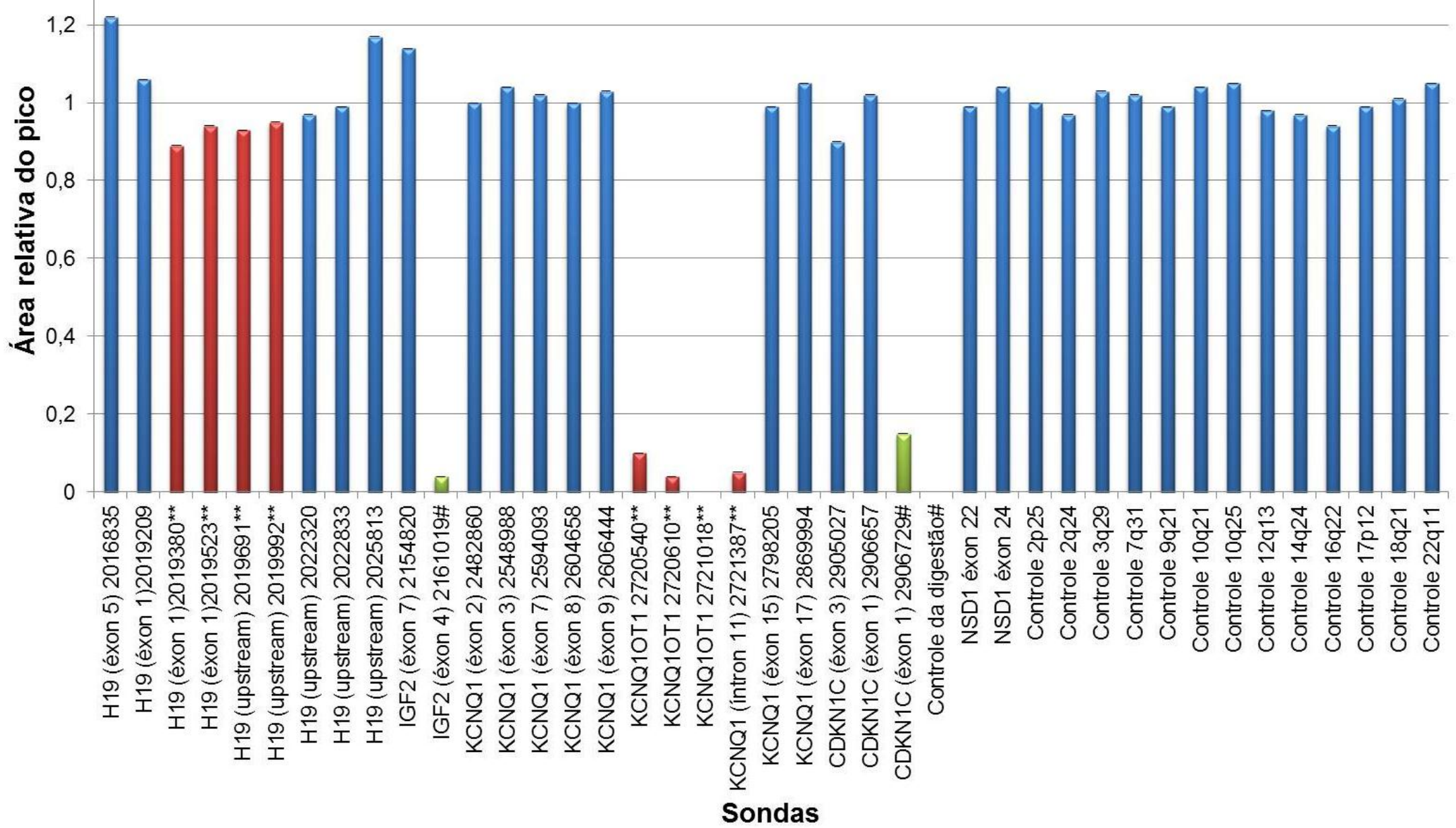

Gráfico 9. Perfil epigenético das ICRs 1 e 2 em paciente com DUPpat completa. Resultado do ensaio MS-MLPA para o paciente HHI 209 mostrando perfil epigenético de hipermetilação na ICR1 (lado esquerdo em vermelho) e hipometilação na ICR2 (centro em vermelho). O controle da digestão mostra a ausência de pico. Em verde, o perfil de metilação para os genes IGF2 e CDKN1C. Eixo x: sondas para região 11 p15.5 e sondas-controle. Mais informações sobre as sondas na tabela 5. 


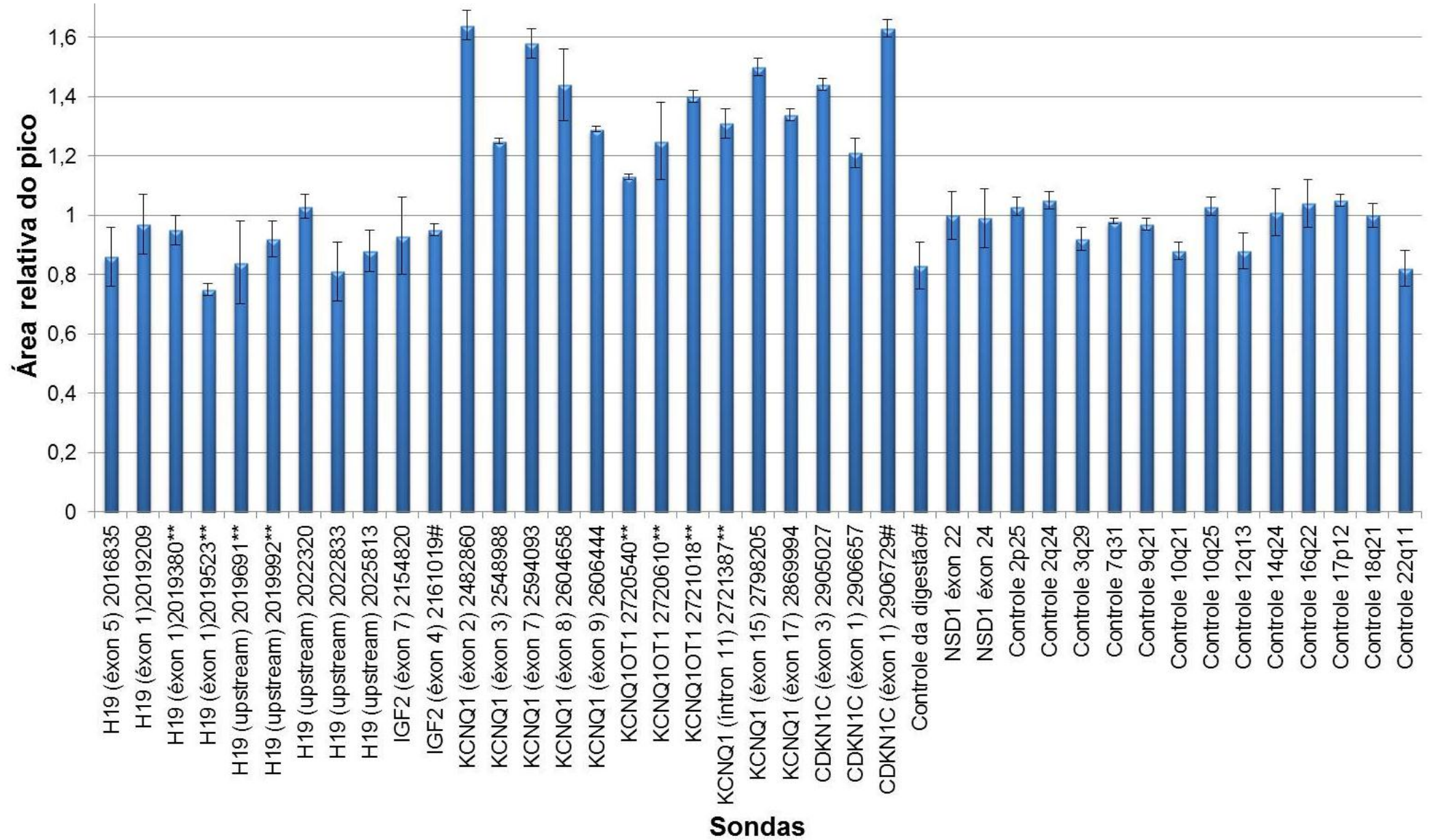

Gráfico 10. Perfil quantitativo da região 11 p15.5 em paciente com duplicação da ICR2. Resultado do ensaio MS-MLPA para o paciente SSR 1312 mostrando aumento na área relativa dos picos (eixo y) com valores acima de 1,25 entre os genes KCNQ1 e CDKN1C, abrangendo a ICR2 e valores normais (entre 0,75 e 1,25) para as demais sondas. Eixo x: sondas para região $11 p 15.5$ e sondas-controle. Mais informações sobre as sondas na tabela 5 . 


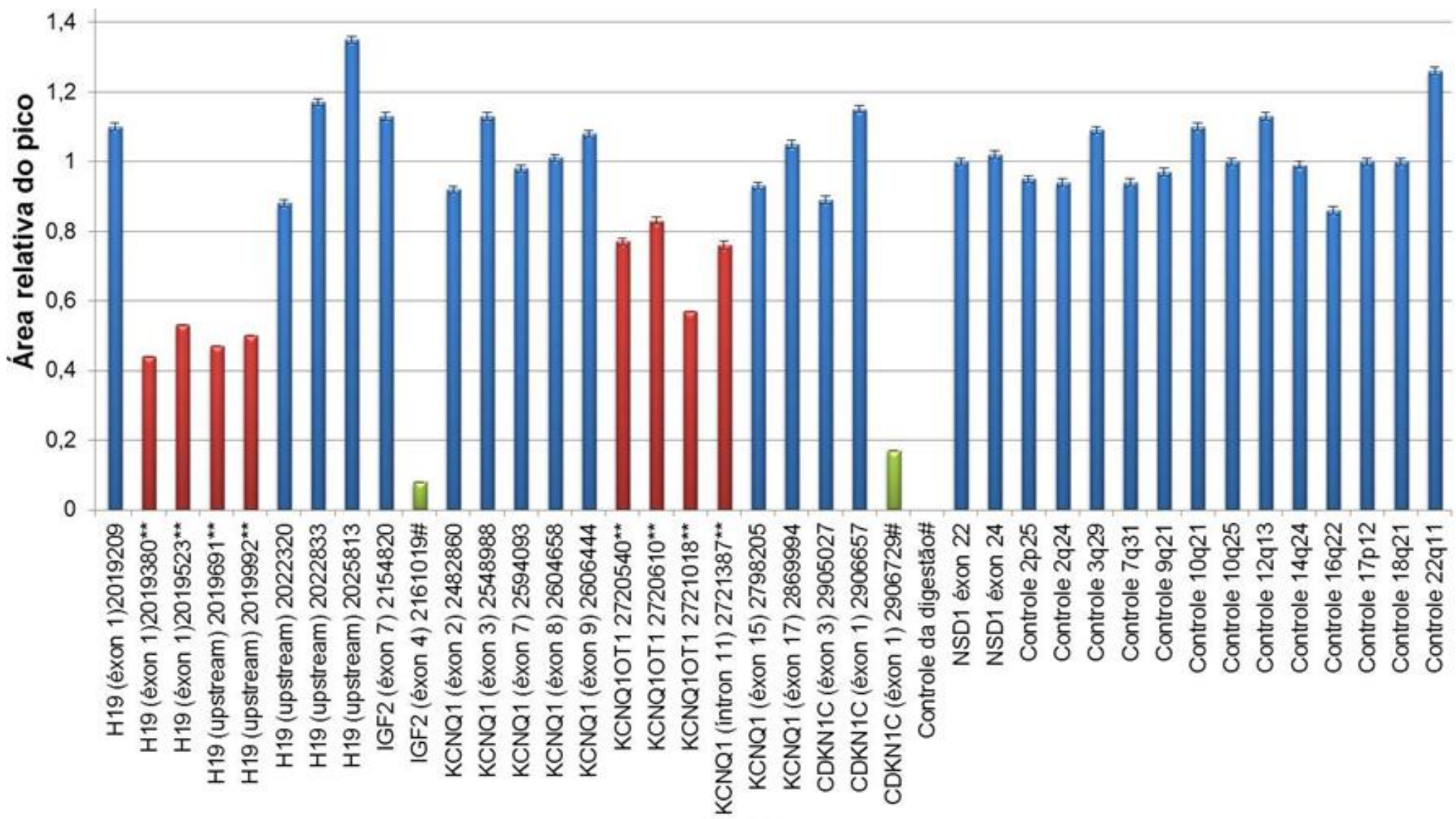

Sondas

Gráfico 11. Perfil epigenético das ICRs 1 e 2 em paciente com hipermetilação da ICR2. Resultado do ensaio MS-MLPA para o paciente SSR 1312 com duplicação materna da ICR2, mostrando perfil epigenético normal na ICR1 (lado esquerdo em vermelho) e hipermetilação na ICR2 (centro em vermelho). O controle da digestão mostra a ausência de pico. Em verde, o perfil de metilação para os genes IGF2 e CDKN1C. Eixo $\mathrm{x}$ : sondas para região 11 p15.5 e sondas-controle. Mais informações sobre as sondas na tabela 5. 


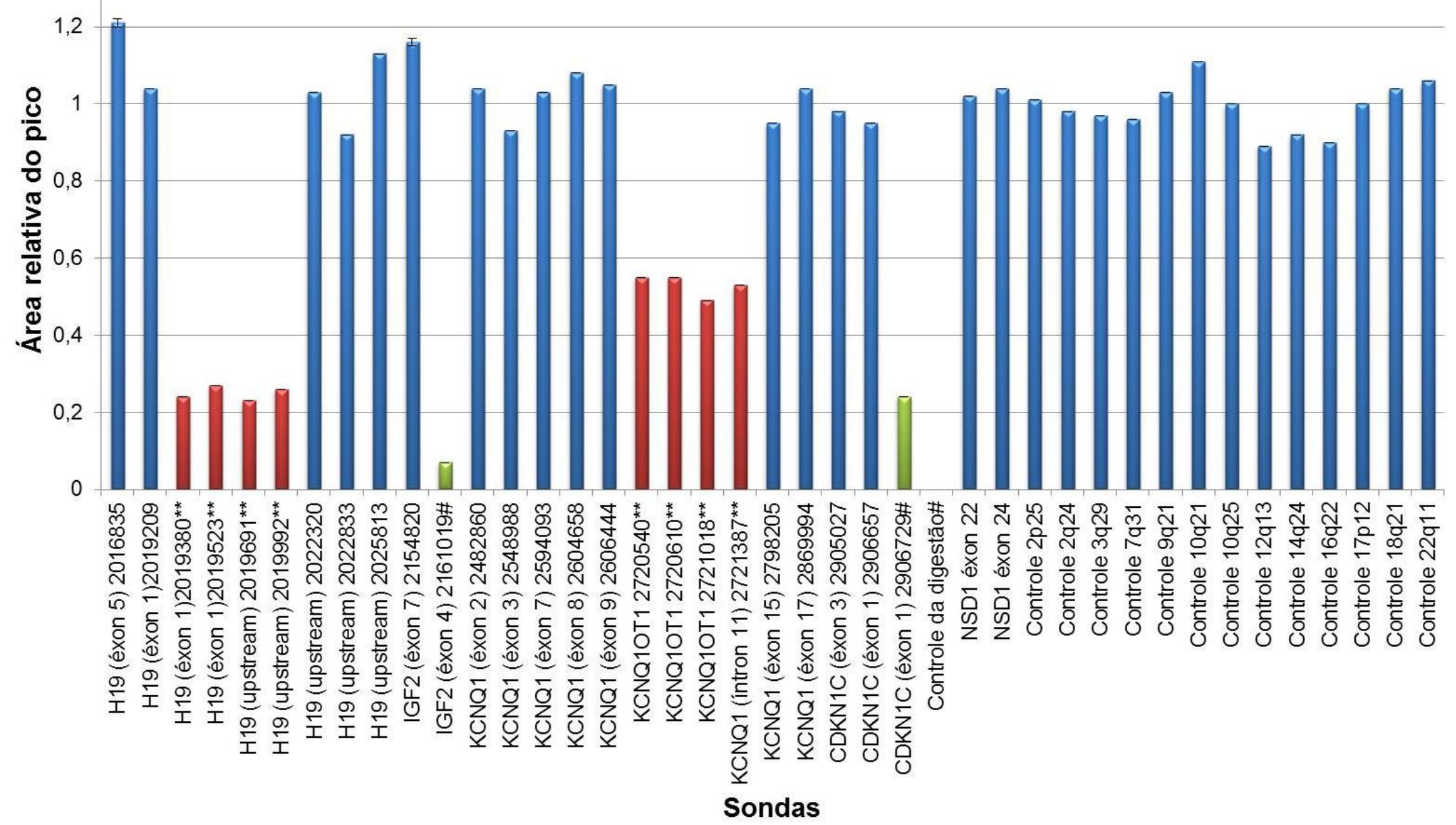

Gráfico 12. Perfil epigenético das ICRs 1 e 2 em paciente com hipometilação da ICR1. Resultado do ensaio MS-MLPA para o paciente SSR 1379 mostrando perfil epigenético normal na ICR2 (centro em vermelho) e hipometilação na ICR1 (lado esquerdo em vermelho). O controle da digestão mostra a ausência de pico. Em verde, o perfil de metilação para os genes IGF2 e CDKN1C. Eixo x: sondas para região 11 p15.5 e sondas-controle. Mais informações sobre as sondas na tabela 5. 


\subsection{DESM-RT}

Para o ensaio de DESM-RT foram selecionados 24 pacientes com o perfil de metilação conhecido, estabelecido previamente por MS-MLPA. Foram excluídos os casos em que o desvio padrão da triplicata foi superior a 0,17 . A figura 22 exemplifica os perfis observados para metilação normal, hipometilação e hipermetilção na ICR2, para alguns pacientes, utilizando-se a técnica de DESM-RT. Em um perfil hipometilado, o Ct da amostra digerida com a enzima Hpall fica próximo ao da amostra digerida com a enzima Mspl. Em um perfil hipermetilado, o Ct da amostra digerida com a enzima Hpall fica próximo ao da amostra não digerida. Para as ICRs 1 e 2, os valores observados foram fortemente correlacionados (coeficiente de correlação de Pearson $\rho=0,94$ ) para a ICR1 tabela 19 e o mesmo valor $(\rho=0,94)$ foi encontrado para a ICR2 (Tabela 20).

Tabela 19. Correlação entre os resultados obtidos pelas técnicas de MS-MLPA e DESM-RT para a ICR1 $(\rho=0,94)$. Os valores estão em porcentagem de metilação observada.

\begin{tabular}{lcc}
\hline Paciente & MS-MLPA & DESM-RT \\
\hline SSR 1006 & 20 & 15 \\
SSR 1368 & 25 & 21 \\
SSR 1379 & 25 & 17 \\
SBW 1601 & 44 & 59 \\
SBW 744 & 46 & 41 \\
SSR 1377 & 47 & 43 \\
SBW 171 & 48 & 49 \\
SSR 1312 & 49 & 40 \\
SSR 1312irmã & 51 & 41 \\
SSR 1382 & 51 & 36 \\
SBW 1613 & 57 & 54 \\
SBW 228 & 63 & 66 \\
SBW 630 & 71 & 71 \\
HHI 211 & 85 & 87 \\
\hline
\end{tabular}

Os números dos pacientes correspondem ao código do laboratório. SSR_síndrome de Silver-Russell; SBW_síndrome de Beckwith-Wiedemann; HHI_Hemihiperplasia isolada. 
Tabela 20: Correlação entre os resultados obtidos pelas técnicas de MS-MLPA e DESM-RT para a ICR2 $(\rho=0,94)$. Os valores estão em porcentagem de metilação observada.

\begin{tabular}{lcc}
\hline Paciente & MS-MLPA & DESM-RT \\
\hline HHI 209 & 5 & 1 \\
SBW131 & 7 & 3 \\
SBW 171 & 11 & 8 \\
SBW 160 & 23 & 20 \\
HHI 211 & 25 & 15 \\
SBW630 & 29 & 31 \\
SBW 228 & 43 & 49 \\
SBW 1613 & 44 & 48 \\
HHI 101 & 47 & 45 \\
HHI 33 & 50 & 47 \\
SSR 1377 & 50 & 60 \\
SBW744 & 51 & 63 \\
SBW1015 & 52 & 64 \\
SBW1601 & 52 & 52 \\
HHI 627 & 52 & 45 \\
SSR 1379 & 53 & 51 \\
SSR 1006 & 53 & 49 \\
SSR 1368 & 55 & 47 \\
SSR 1382 & 61 & 51 \\
SSR 1312 irmão & 66 & 73 \\
SSR 1312irmã & 72 & 61 \\
SSR 1312 & 73 & 60 \\
\hline
\end{tabular}

Os números dos pacientes correspondem ao código do laboratório. SSR_síndrome de Silver-Russell; SBW_síndrome de Beckwith-Wiedemann; HHI_Hemihiperplasia isolada. 

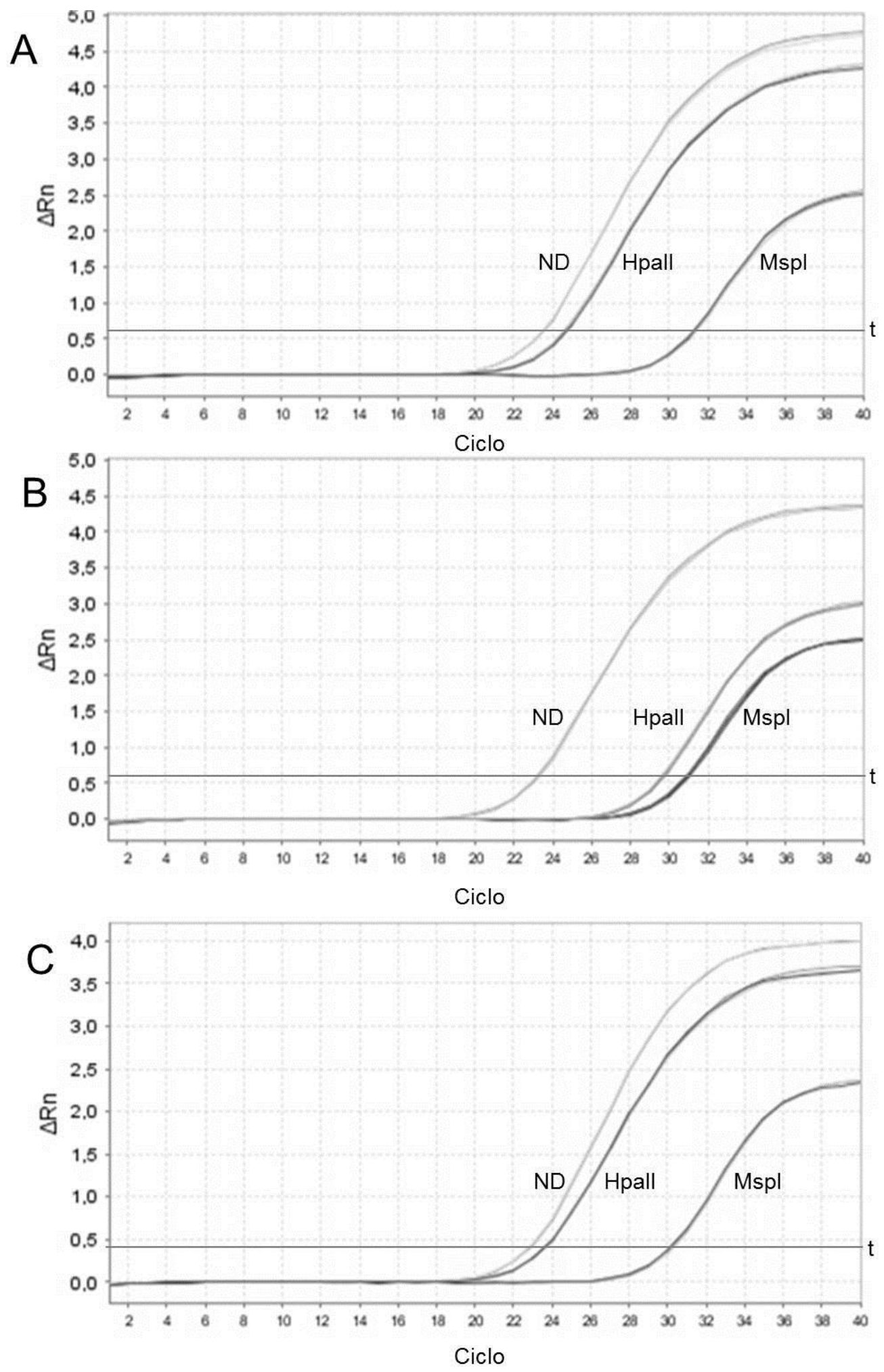

Figura 22. Exemplo de DESM-RT para a ICR2. Exemplos de um padrão de metilação normal $(47 \%)(\mathrm{A})$, hipometilação $(1 \%)(B)$, e hipermetilação $(73 \%)(C)$ na ICR2. $\Delta R n-$ magnitude do sinal gerado por uma condição específica de PCR; t- threshold, nível de fluorescência arbitrário; ND - amostra não digerida; Hpall e Mspl - amostra digerida com as respectivas enzimas. A porcentagem de metilação foi calculada pela fórmula $1 / 2^{\text {(ct Hpall - ct nd) }}$. (Ct) cycle threshold, corresponde ao número do ciclo no qual o nível de fluorescência emitido pela amostra amplificada atingiu o nível arbitrário (t). 


\subsection{DESM-QFPCR}

Para o ensaio de DESM-QFPCR foram selecionados oito pacientes com o perfil de metilação conhecido, estabelecido previamente por MS-MLPA. Para a ICR2, os valores observados foram fortemente correlacionados $(\rho=0,95)$ (Tabela 21). Para a ICR1 não houve correlação significativa entre as técnicas $(\rho=0,50)$ (Tabela 22). A figura 23 exemplifica os perfis observados para metilação normal, hipometilação e hipermetilção na ICR2 pela técnica de DESM-QFPCR.

Tabela 21. Correlação entre as técnicas de MS-MLPA e DESM-QFPCR para a ICR2. Os valores estão em porcentagem de metilação observada $(\rho=0,95)$.

\begin{tabular}{lcc}
\hline Paciente & MS-MLPA & DESM-QFPCR \\
\hline SBW 131 & 7 & 7 \\
SBW 171 & 11 & 5 \\
SBW 630 & 29 & 24 \\
SBW 228 & 43 & 49 \\
SBW 744 & 51 & 50 \\
SBW 1015 & 52 & 40 \\
SSR1006 & 53 & 35 \\
SSR1312 & 73 & 70 \\
\hline
\end{tabular}

Tabela 22. Correlação entre as técnicas de MS-MLPA e DESM-QFPCR para a ICR1. Os valores estão em porcentagem de metilação observada $(\rho=0,95)$.

\begin{tabular}{lcc}
\hline Paciente & MS-MLPA & DESM-QFPCR \\
\hline SSR 1006 & 20 & 27 \\
SBW 1601 & 44 & 90 \\
SBW 1613 & 44 & 67 \\
SBW 131 & 46 & 82 \\
SBW 744 & 46 & 80 \\
SSR 1312 & 49 & 70 \\
SBW 630 & 71 & 74 \\
SBW 1015 & 74 & 68 \\
\hline
\end{tabular}



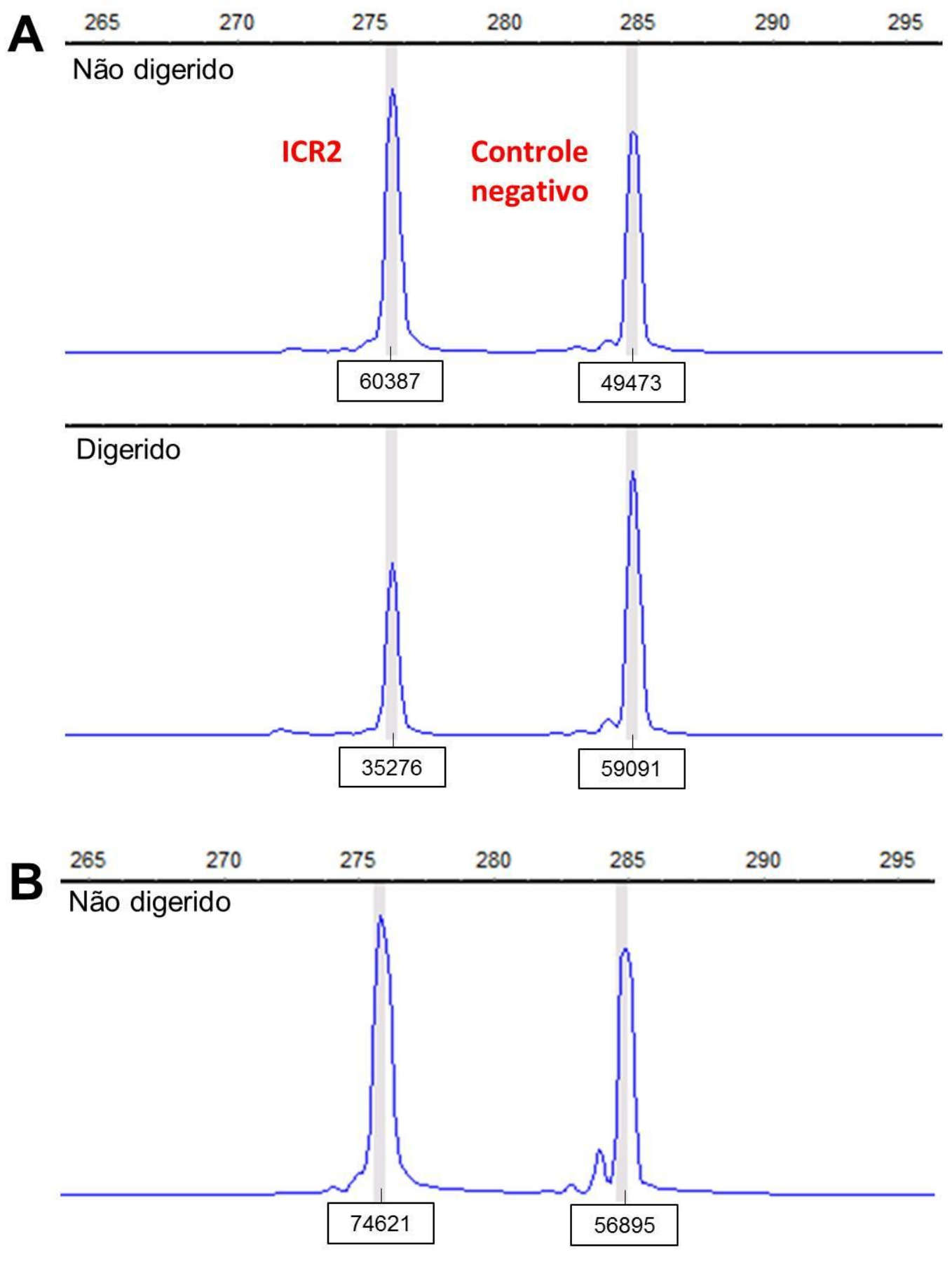

Digerido

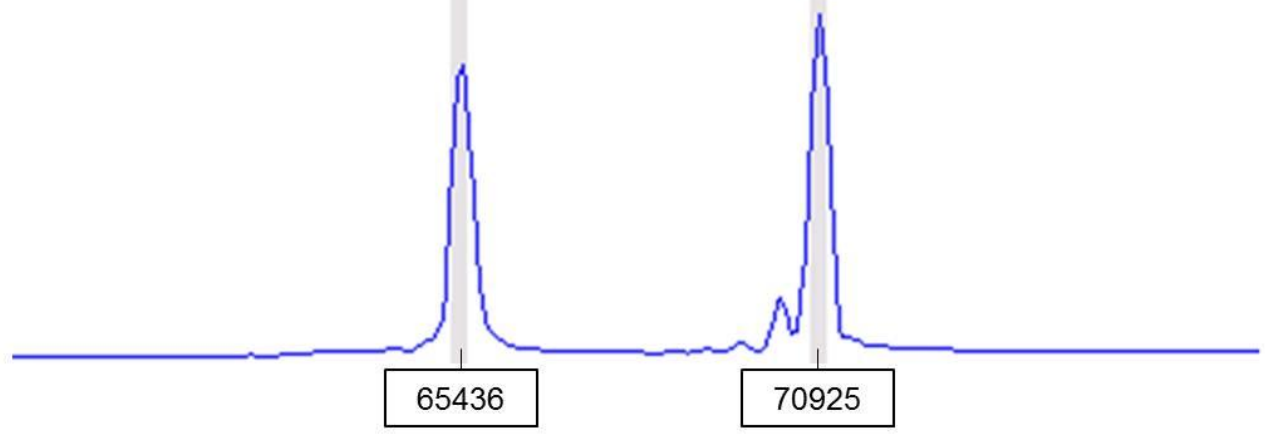




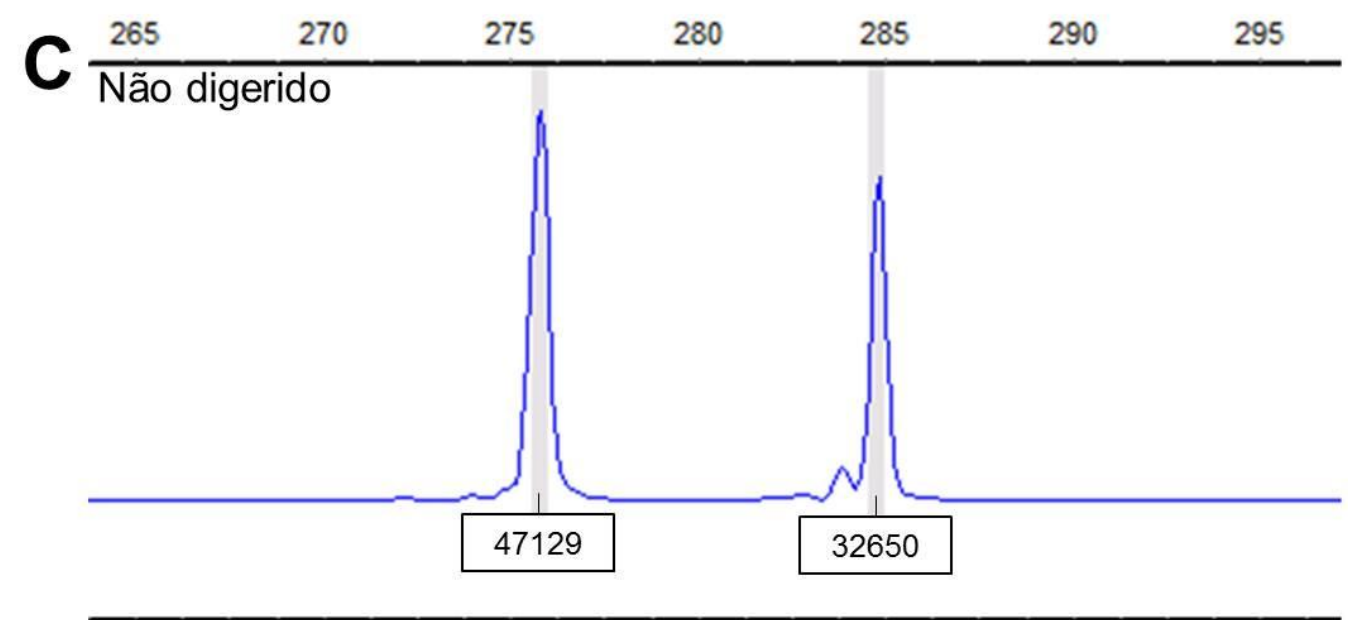

Digerido

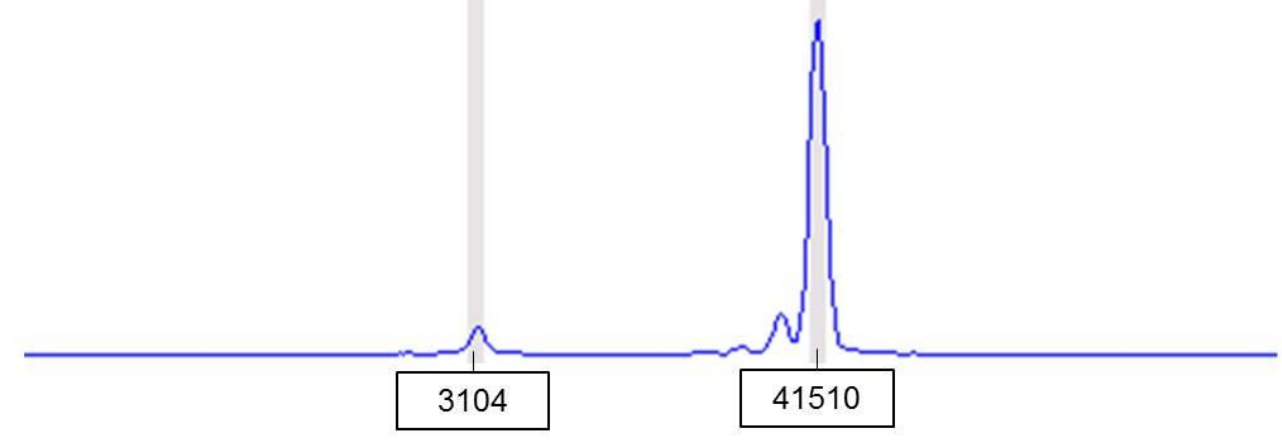

Figura 23. Exemplo do ensaio DESM-QFPCR na ICR2. Eletroferograma do perfil de metilação observado para a ICR2 de indivíduos com metilação normal $(A)$, hipermetilação (B) e hipometilação (C). Nas caixas de texto estão as áreas dos picos em unidades relativas de fluorescência, a linha superior indica o tamanho do amplicon em pares de nucleotídeos. 


\subsection{SNapShot}

Indivíduos com o padrão de metilação e genótipos de microssatélites no cromossomo 11 conhecidos, foram selecionados para genotipagem quantitativa de SNPs por eletroforese capilar. Antes da purificação, os produtos de amplificação dos genes alvo foram conferidos por eletroforese em gel de agarose (Figura 24).

Indivíduos com DUP paterna em 11p15.5 (HHI 211, SBW 80, SBW 175, SBW 213), duplicação paterna (SBW 228) ou duplicação materna (SSR 1314) apresentaram uma desproporção quantitativa entre os SNPs informativos. O SNP mais informativo foi o KCNQ1OT1a com 6/11 indivíduos heterozigotos. O menos informativo foi o H19 3/12. Dez dos 12 indivíduos foram informativos para pelo menos um marcador (Tabela 23). A figura 25 mostra o genótipo de três indivíduos para o SNP rs680 no gene IGF2. A figura 26 exemplifica os diferentes genótipos observados nos genes H19 e KCNQ1OT1.

Figura 24. Amplicons alvo para o minissequenciamento. Eletroforese em gel de agarose $2 \%$ corado com brometo de etídeo dos produtos de amplificação do indivíduo SBW 80 . Na primeira coluna, 100 bp DNA Ladder.

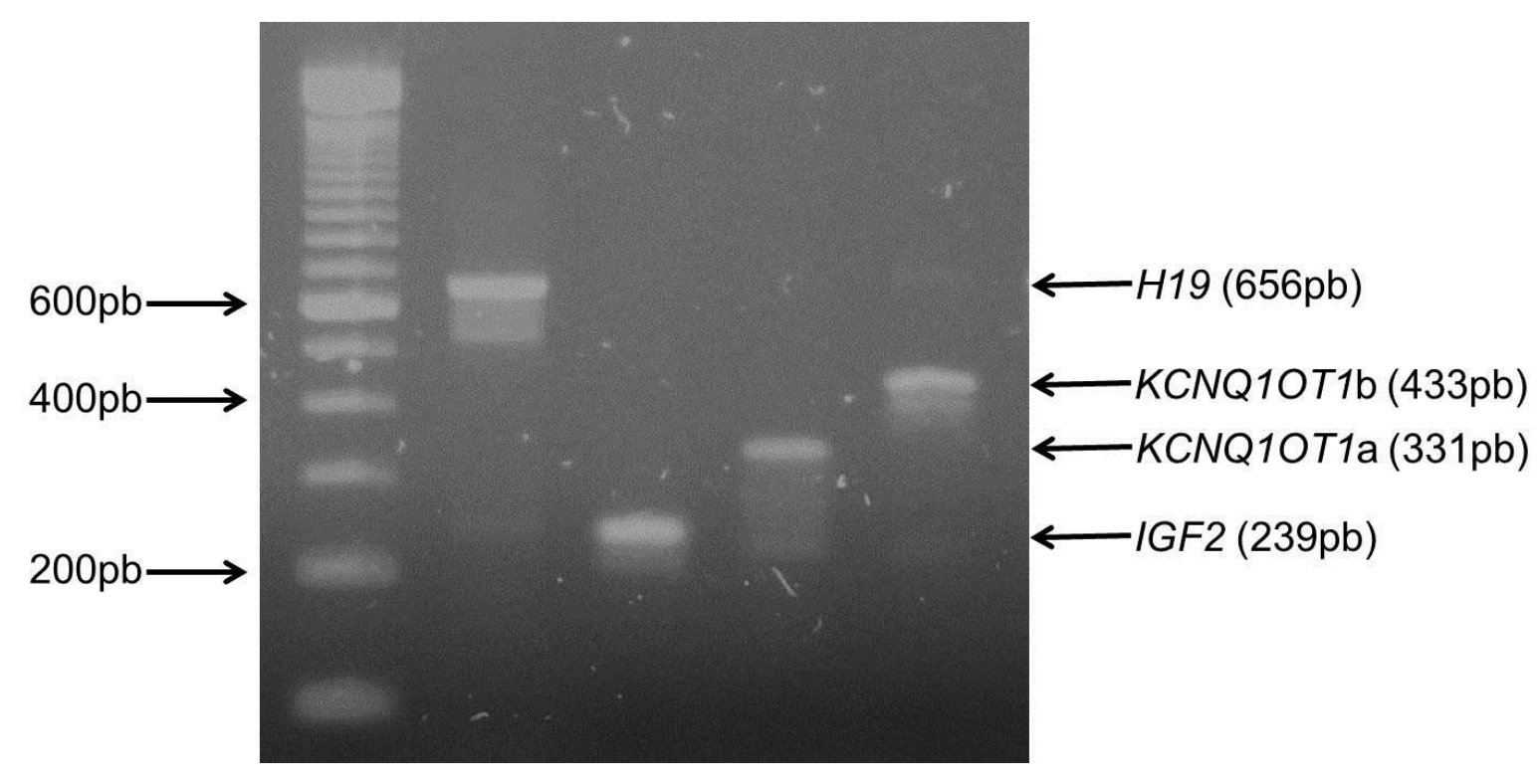


Tabela 23. Genótipos dos pacientes selecionados para o minissequenciamento.

\begin{tabular}{lcccc}
\hline Indivíduo & H19 & IGF2 & KCNQ1OT1a & KCNQ1OT1b \\
\hline HHI 211 & C/T & G/A & G/A & G/G \\
SBW 80 & C/T & G/G & G/G & G/A \\
SBW 129 & C/C & G/G & A/A & G/G \\
SBW 131 & T/T & G/G & G/G & G/A \\
SBW 175 & T/T & G/A & G/A & G/G \\
SBW 213 & C/C & G/A & G/A & G/G \\
SBW 228 & C/T & G/G & G/A & G/G \\
SBW 1601 & T/T & G/G & G/G & G/G \\
SSR 1314 & C/C & G/A & G/A & G/A \\
SSR 1356 & N & G/A & N & G/A \\
SSR 1368 & T/T & G/G & G/G & G/A \\
SSR 1380 & T/T & G/A & G/A & G/G \\
\hline
\end{tabular}

$\mathrm{N}$ : não determinado; em negrito, o alelo desbalanceado com maior quantidade de produto amplificado.

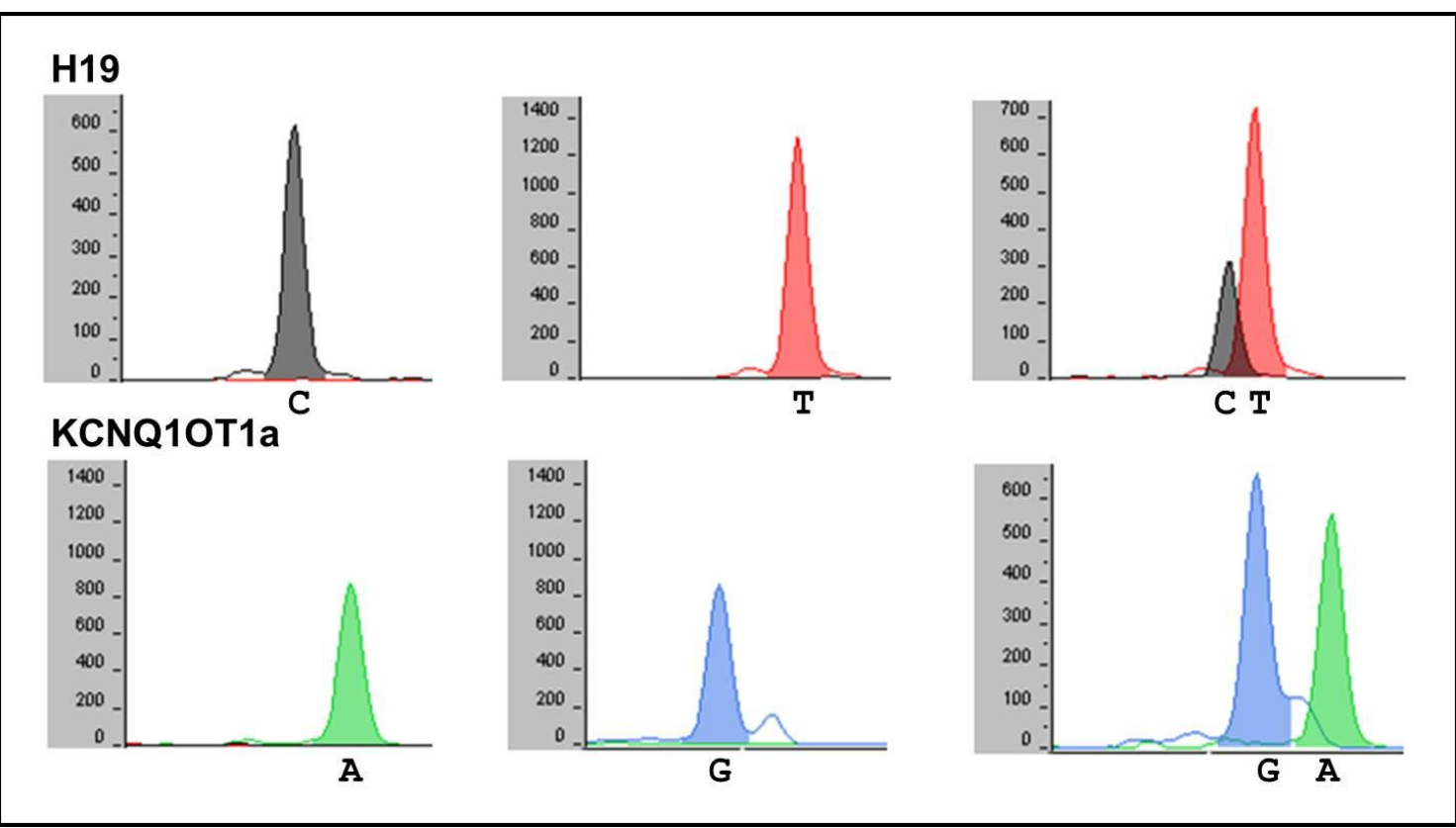

Figura 25. Minissequenciamento dos SNPs rs2839704 (H19) e rs760419 (KCNQ1OT1). Painel superior: três indivíduos com diferentes genótipos $(C / C),(T / T)$ e $(C / T)$ no gene $H 19$. $\mathrm{O}$ indivíduo com genótipo $(\mathrm{C} / \mathrm{T})$ possui uma duplicação paterna em 11p15.5. Painel inferior: exemplo de indivíduos com diferentes genótipos (A/A), (G/G) e (G/A) observados para o gene KCNQ1OT1. A quantificação alélica é representada no eixo y em unidades relativas de fluorescência. 

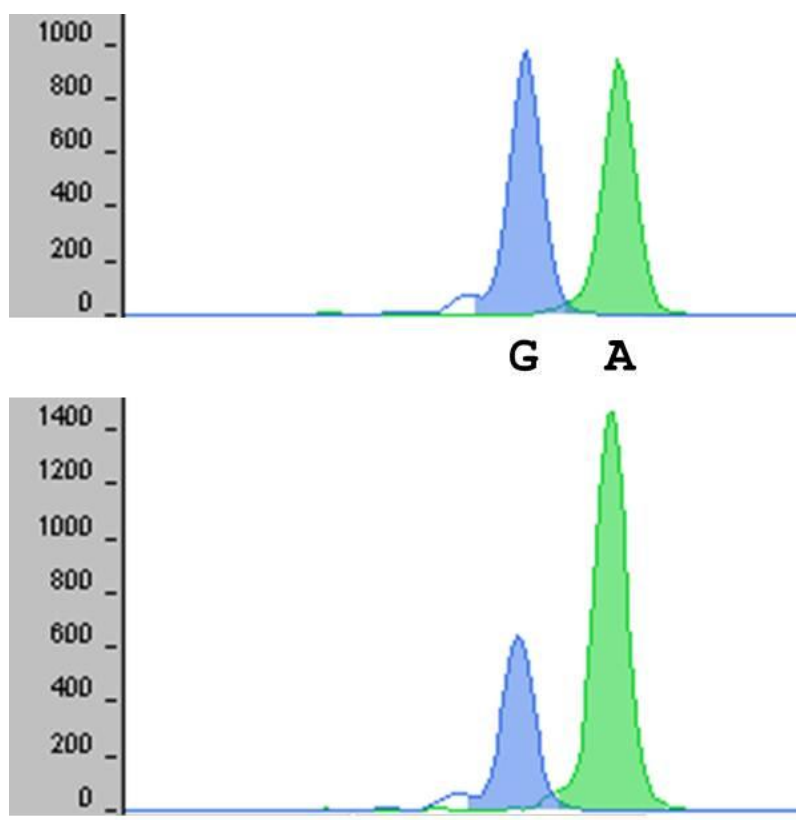

G A

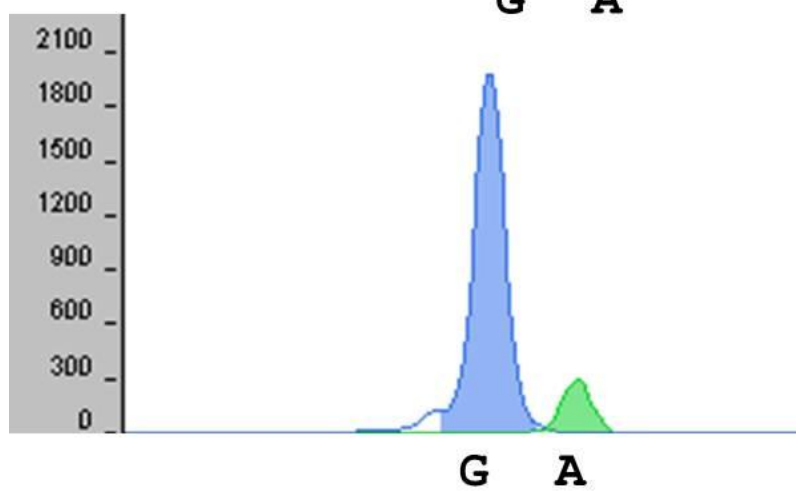

Figura 26. Minissequenciamento do SNP rs680 no gene IGF2. Indivíduos heterozigotos G (azul)/A (verde). Painel superior: indivíduo com herança biparental; painéis central e inferior: indivíduos com dissomia uniparental paterna (DUPpat). Note a desproporção alélica nos indivíduos com DUPpat. A quantificação alélica é representada no eixo y em unidades relativas de fluorescência. 


\section{DISCUSSÃo}

As alterações epigenéticas do imprinting genômico na região 11 p15.5 em doenças humanas muitas vezes envolvem e/ou são secundárias a alterações genéticas, como a DUP e mutações em ICRs. Mutações em fatores que atuam em cis ou trans na manutenção do imprinting alteram o padrão normal de marcação (Sparago et al., 2004; Prawitt et al., 2005; Demars et al., 2010; Crescenzo et al., 2011; Poole et al., 2011). A dissomia uniparental paterna (DUPpat) é um fator importante de alteração do imprinting genômico na síndrome de BeckwithWiedemann (SBW), responsável por cerca de $20 \%$ dos casos (Weksberg et al., 2010) e também está presente em aproximadamente 14\% (11-16\% de acordo com diferentes autores) das HHI (Martin et al., 2005; Shuman et al., 2006). DUPmat do cromossomo 11 na síndrome de Silver-Russell (SSR) é um evento raro (Bullman et al., 2008), já a DUPmat do cromossomo 7 é responsável por aproximadamente 510\% dos casos de SSR (Eggermann, 2010). A maioria das detecções de DUPpat do cromossomo 11 e DUPmat do cromossomo 7 é realizada por meio da análise de marcadores microssatélites.

Neste trabalho foi desenvolvida uma nova técnica para estudo de metilação do DNA de ICRs e testados marcadores microssatélites inéditos na região 11 p15, para pesquisa de DUP e de alteração estrutural deste cromossomo. O estudo avaliou pacientes com SBW, SSR e HHI, que são protótipos de doenças que envolvem alterações do impriniting genômico. Os resultados foram comparados com metodologias mais tradicionais de avaliação desses casos, como DESM-RT e MSMLPA. Esta última técnica também permitiu a detecção de mutação no gene CDKN1C.

\subsection{Novos marcadores microssatélites para os cromossomos 11 e 7}

Os microssatélites utilizados para deteç̧ão de DUP são em sua grande maioria do tipo dinucleotídeos. Este tipo de marcador possui, como característica intrínseca, um perfil eletroforético de difícil interpretação devido à formação de

produtos stutter (Shinde et al.,2003). A taxa de formação do stutter é inversamente proporcional ao tamanho da unidade de repetição (Fan e Chu, 2007). Outra 
característica indesejável é a amplificação preferencial do alelo menor em indivíduos heterozigotos.

Os motivos que influenciam na escolha dos microssatélites para detecção de DUPpat para o cromossomo 11 têm sido, principalmente, a posição física do marcador em relação à região de interesse. Os principais marcadores utilizados estão presentes na região 11p15.5. Até o momento, nenhuma publicação discute em profundidade quais seriam os melhores marcadores para detecção de DUPpat. A informatividade do marcador é sinônimo de sua taxa de heterozigose. Mesmo nos casos em que os pais compartilham genótipos semelhantes, a origem do alelo alterado pode ser determinada pelos dados clínicos do paciente. Na literatura, também não há dados sobre taxas de heterozigose para microssatélites no cromossomo 11.

Com uma abordagem in silico, utilizando ferramentas de bioinformática, no presente estudo foram detectados 1556 marcadores do tipo tetranucleotídeos ou pentanucleotídeos no cromossomo 11 e outros 2060 no cromossomo 7, que não apresentam as características indesejáveis dos dinucleotídeos. Os parâmetros de busca foram semelhantes aos previamente utilizados para caracterização de novos microssatélites no cromossomo X (Machado e Medina-Acosta, 2009; Machado et al., 2009).

Entre os genes controlados pelas ICRs 1 e 2, apenas três marcadores têm sido frequentemente utilizados na literatura, um tetranucleotídeo $(\mathrm{TH})$ e dois dinucleotídeos (D11S1318 e D11S4088). Na mesma região, cinco marcadores foram caracterizados, quatro tetranucleotídeos e um pentanucleotídeos. Quatro deles presentes no gene imprinted KCNQ1, um deles com sobreposição ao gene KCNQ1OT1. Estes marcadores estão em uma região rica em hot-spots de recombinação devido ao envolvimento de sequências específicas do DNA e fatores epigenéticos nesta região (Sandovici et al., 2006).

Dos indivíduos testados com quatro marcadores entre os genes regulados pelas ICRs 1 e 2 a informatividade combinada, que significa pelo menos um marcador heterozigoto, foi de $97 \%$. Para três dos quatro marcadores desenvolvidos no gene KCNQ1, a informatividade combinada foi de $90 \%$. Os 11 marcadores do cromossomo 11 com informatividade avaliada apresentaram taxa de heterozigose média de 69\% (34-91\%). Se o quinto marcador desenvolvido na mesma região 
mantiver esta média, a taxa de informatividade do ensaio poderá chegar a 99\%, e a 96\% no gene KCNQ1.

Os oligonucleotídeos foram sintetizados com diferentes fluorocromos para permitir a QF-PCR e eletroforese simultânea de múltiplos marcadores. A marcação diferencial permite que amplicons do mesmo tamanho sejam discriminados pelos fluorocromos. Neste trabalho, as PCRs foram realizadas individualmente e a eletroforese, com até quatro marcadores por corrida. Foram feitas tentativas de PCR multiplex, mas os resultados não ficaram como o esperado. O sistema multiplex permitiria uma grande redução no consumo de reagentes e no custo do ensaio. $\mathrm{Na}$ eletroforese capilar há uma relação que deve ser mantida entre a quantidade de produto da PCR e de formamida, dificultando inserir mais do que quatro produtos em uma mesma corrida. Colocando-se quatro produtos da PCR na mesma corrida, a quantidade de polímero gasto é $25 \%$ do que seria utilizado para a corrida de cada marcador separadamente, aumentando também a vida útil do capilar do sistema de eletroforese. Como perspectiva de continuação deste trabalho, seria interessante a montagem futura de um sistema multiplex, visando genotipar até sete marcadores no mesmo tubo, como ocorre para outros modelos (Machado et al., 2009).

Na síntese de DNA in vitro, a DNA polimerase pode catalisar a adição de um único nucleotídeo (predominantemente adenosina) ao terminal 3' dos produtos da PCR (Magnuson et al.,1996). Esta adição resulta em um produto de PCR com um nucleotídeo a mais do que a sequência alvo, gerando um perfil na eletroforese denominado "+A". No eletroferograma, eles são observados como picos bipartidos, diferindo em um nucleotídeo no tamanho do amplicon original. Uma das maneiras de corrigir este efeito é estimular a adição completa do nucleotídeo extra, aumentando o tempo de extensão final da PCR para uma hora a 60 minutos.

Mesmo com a adição desta etapa, observamos para muitos marcadores picos bipartidos com $+\mathrm{A}$ incompletos. Lembrando que os sttuters não devem ser confundidos com $0+A$. Curiosamente, o tipo de polímero influencia no perfil eletroforético. Comparamos o mesmo produto da PCR de vários marcadores, em corridas com dois polímeros diferentes (POP7 e POP4 da Applied Biosystems). Perfis $+A$ foram observados com o polímero $P O P 7$, enquanto picos únicos foram observados com o POP 4 (dados não mostrados).

A amplificação preferencial do alelo menor em indivíduos heterozigotos, com diferença maior do que seis repetições, foi observada para alguns marcadores, 
embora tenha ficado nos padrões considerados normais com proporção entre as áreas dos picos entre 0,8 e 1,4 (Hultén et al., 2003). Apenas para o marcador D11S2835854, alguns indivíduos apresentaram desproporção alélica significativa e as condições da PCR para este marcador devem ser modificadas.

\subsection{Alterações genéticas na SBW, HHI e SSR}

$\mathrm{Na} \mathrm{HHI}$, a única alteração genética observada foi a DUPpat do cromossomo 11 (DUPpat Cr11) em 13\% dos pacientes, semelhante a taxas observadas anteriormente (11-16\%) (Martin et al., 2005; Shuman et al., 2006). No paciente HHI 209, a DUPpat para marcadores da região 11 p15.5 foi completa, com níveis de alelos maternos não detectáveis. Para excluir um possível erro de troca de amostras, o trio (pai, mãe e paciente) foi genotipado com outros marcadores autossômicos, indicando inclusão da maternidade. Para a região $11 q$ o paciente apresentou DUP.

Em pacientes com SSR, a única alteração genética observada foi a duplicação materna encontrada na família previamente descrita por Bonaldi e colaboradores (2011). Esses autores mapearam a extensão da duplicação com ensaio de microarranjo de DNA, e observaram um segmento duplicado de aproximadamente $1,61 \mathrm{Mb}$ que se estendeu para a região $11 \mathrm{p} 15.4$. Os microssatélites dentro desta região também indicaram duplicação, enquanto os de fora indicaram padrão normal. O ensaio de MS-MLPA foi realizado como descrito anteriormente (Bonaldi et al., 2011), sendo observada a duplicação restrita à ICR2 com as sondas do kit comercial. Apenas mais um caso de microduplicação restrita à ICR2 foi descrito, mas com uma duplicação de aproximadamente 1Mb (Schonherr et al., 2007). Uma microduplicação restrita à ICR1 herdada maternalmente de aproximadamente $570 \mathrm{~kb}$ foi recentemente descrita em uma paciente com SSR (Demars et al., 2011).

Entre os pacientes com SSR que tiveram os pais disponíveis para verificação de DUPmat para o cromossomo 7 (DUPmat Cr7), nenhum apresentou alteração. Provavelmente, com um maior número de pais disponíveis a DUPmat Cr7 seria observada, visto que esta alteração está presente, segundo a literatura, em aproximadamente em 10\% dos casos (Eggermann et al., 2010). No entanto, houve 
dificuldade no recrutamento dos pais, pois várias crianças deste grupo eram trazidas aos atendimentos médicos pelos avós ou tios. Em aproximadamente metade dos casos de DUPmat Cr7 na literatura, o perfil genético encontrado foi de isodissomia sugerindo um mecanismo de formação pós-zigótico de erro na segregação mitótica, e na outra metade, heterodissomia completa ou parcial indicando resgate da dissomia a partir de embrião trissômico (Mergenthaler et al., 2000).

Na maioria dos casos, a DUPmat Cr7 é completa, mas pode também se apresentar na forma de mosaico (Fuke-Sato et al., 2012). Mesmo com a ausência da maioria dos pais, os pacientes com SSR foram investigados para esse tipo de alteração. Foi considerada a presença de mosaicismo quando os picos nos indivíduos heterozigotos apresentavam uma razão desigual significativa maior do que 3:1. Em todos os pacientes, os alelos dos marcadores informativos no cromossomo 7 apresentaram proporções aproximadas de 1:1. Em 2009, Giardiana e colaboradores desenvolveram e validaram pela primeira vez um método efetivo baseado em eletroforese capilar para detecção de DUPmat Cr7 com dois sistemas multiplex, cada um com quatro microssatélites (Giardina et al., 2007). Em um eletroferograma mostrado no artigo, os alelos de um indivíduo normal apresentaram razões entre áreas dos picos acima de 1,6:1, para dois marcadores. No entanto, estes marcadores eram inadequados para detecção de mosaicismo. Todos os marcadores dos dois sistemas multiplex eram dinucleotídeos e a heterozigose observada variou de $(0,71-0,86)$. Para os novos marcadores do cromossomo 7 , do presente estudo, foi observada uma taxa de heterozigose inferior $(0,66-0,81)$, porém, todos os marcadores apresentaram alelos com proporções próximas de 1:1 nos indivíduos heterozigotos. Apesar de rara, a DUPmar Cr11 em mosaico também é uma das causas da SSR (Bullman et al., 2008). Portanto, com o mesmo raciocínio para detecção de DUPmat Cr7 em mosaico, os pacientes foram genotipados com marcadores do cromossomo 11. Em nenhum dos pacientes foi observado perfil sugestivo de mosaicismo, com razões entre os picos próximas de 1:1.

Nos pacientes com SBW, foram encontradas diferentes alterações genéticas. Em um caso (SBW 228) foi observada uma duplicação paterna entre os marcadores D11S1790947 e D11S3146034, que abrange as ICRs 1 e 2. O ensaio MS-MLPA mostrou duplicação para todas as sondas presentes nos genes controlados pelas ICRs 1 e 2. Os pais do paciente não apresentaram nenhuma alteração detectável com os marcadores do cromossomo 11. As amostras deste paciente foram utilizadas 
como controles em diferentes ensaios de MS-MLPA. A duplicação possuia pelo menos 1,35 Mb abrangendo 30 genes. O perfil alélico observado descartou uma duplicação em cis, pois o paciente possuia ambos os alelos paternos. Este perfil alélico é compatível com segregação de uma translocação críptica balanceada de origem paterna ou de uma duplicação de novo resultante de uma recombinação desigual na meiose I paterna (Russo et al. 2006). Bliek e colaboradores (2009) encontraram uma família segregando uma translocação envolvendo os cromossomo 4 e 11 [t(4;11)(q35;p15.5)] abrangendo ambas as ICRs. Trata-se de um evento raro, pois translocações e duplicações correspondem a menos de $2 \%$ dos casos de SBW (Weksberg et al. 2010). Neste caso, a avaliação por meio de análise citogenética convencional evidenciou cariótipo normal, mas a utilização de outras metodologia (por exemplo, alta resolução e Hibridação in situ fluorescente) poderia auxiliar a elucidar o caso Análise de outros marcadores em 12 autossomos mostrou dissomia biparental normal.

Mutações no gene CDKN1C são responsáveis por aproximadamente $10 \%$ dos casos de SBW (Weksberg et al., 2010). O gene codifica um inibidor de quinase dependente de ciclina e atua como um regulador negativo do ciclo celular. Por meio do ensaio MS-MLPA, foi observada uma grande deleção ainda não descrita na paciente SBW 744. Recentemente, Romanelli e colaboradores (2010) publicaram uma revisão sobre as mutações descritas no gene CDKN1C. Esses autores descreveram sete novas mutações, aumentando para 25 o número de mutações conhecidas. A nova deleção observada possui pelo menos 1700 pares de nucleotídeos abrangendo os éxons 1 e 3 do gene. Os genitores da paciente foram investigados. O seu pai não apresentou alteração estrutural detectável, enquanto a sua mãe apresentou a mesma deleção. Neste caso, o aconselhamento genético com a comunicação de risco de recorrência faz-se necessário. Esta mutação pode não sido detectada anteriormente na literatura, devido ao estado de hemizigose para esta região. A detecção de novas mutações pode ser realizada por meio de sequenciamento com primers cobrindo a região exônica (Lam et al. 1999; Romanelli et al., 2010). Outra possibilidade é que se trata de uma mutação muito rara, visto que ela não foi detectada em trabalhos anteriores por meio de ensaios de PCR/heteroduplex ( $\mathrm{Li}$ et al., 2000), ou polimorfismo conformacional de fita simples (ou SSCP, do inglês, Single-strand conformation polymorphism) (Okamoto et al., 1998). 
Nos pacientes com SBW, a DUPpat Cr11 foi responsável por 19\% dos casos. A demonstração que a DUPpat está envolvida na SBW foi feita em 1991 (Heny et al., 1991). Estudos mostram que a frequência de DUPpat em casos esporádicos de SBW é de aproximadamente 20\% (Catchpoole et al., 1997; Bliek et al., 2001; Wersberg et al., 2010). Enquanto a frequência da DUPpat Cr11 é bem estabelecida, a extensão da alteração no cromossomo 11 não tem sido analisada em detalhe (Cooper et al., 2007; Romanelli et al., 2011). Cooper e colaboradores (2007) analisaram 52 crianças com SBW utilizando um painel de marcadores microssatélites para o cromossomo 11. Em todos os casos foi demostrada isodissomia paterna em mosaico sugerindo um erro mitótico. Em 92\% dos casos, a DUPpat foi restrita a $11 \mathrm{p}$, com recombinação em todo o braço curto, sem evidência de uma região mais propensa à recombinação. Entre os seis pacientes com DUPpat que foram encontrados neste trabalho, nenhum apresentou DUPpat se estendendo para o braço longo do cromossomo e, em todos os casos, a DUPpat da região compreendendo as ICRs 1 e 2 estava presente. A porcentagem de células androgenéticas variou de aproximadamente 35 a 70\% e não houve relação destes valores com a extensão da DUP. Recentemente, mais nove pacientes foram investigados para determinar a extensão da DUPpat (Romanelli et al., 2011), e todos apresentaram alteração restrita ao braço curto cromossômico, sem nenhum ponto principal de recombinação evidente. No mesmo trabalho (Romanelli et al., 2011), foi mostrada a porcentagem de células com DUPpat calculada por seis diferentes marcadores microssatélites. Curiosamente, houve uma grande discrepância na porcentagem de DUPpat para diferentes marcadores em um mesmo paciente. Por exemplo, um paciente apresentou para três diferentes marcadores porcentagens de $81,7 \%, 31,3 \%$ e $9,1 \%$ no segmento cromossômico androgenético. Os autores não discutiram este fato. Para que este perfil seja verdadeiro, diferentes erros mitóticos gerando mais de duas linhagens celulares deveriam ter ocorrido. Uma das causas prováveis da discrepância é que dos seis marcadores utilizados, cinco são dinucleotídeos. Nos casos do trabalho atual em que foi observada DUPpat, todos os marcadores no mesmo indivíduo não apresentaram discrepâncias na porcentagem de células com segmentos cromossômicos androgenéticos. 


\subsection{Alterações (epi) genéticas no caso de displasia mesenquimal placentária}

A displasia mesenquimal placentária (DMP) é uma condição rara caracterizada por uma placenta aumentada de tamanho, com múltiplos cistos. O exame macroscópico mostra vesículas tipo uva que mimetiza uma gravidez molar. Os achados microscópicos mostram vilosidades edematosas grandes, com formação de cisternas intercaladas com vilosidades normais (Ang et al., 2009). Apenas em 2006, o mosaicismo androgenético/biparental foi reconhecido como um dos agentes etiológicos da DMP (Kaiser-Rogers et al. 2006).

Um paciente com DMP foi incluído no estudo, pois em um terço dos casos com essa alteração, a criança apresenta a SBW (H'Mida et al. 2008). O diagnóstico pré-natal, devido às alterações placentárias, evindenciou cariótipo 46,XX/46,XY, confirmado no pós-natal, por análise citogenética do sangue periférico. A criança, do sexo masculino, apresentava fenótipo normal, mas, como esta constituição cromossômica pode ser compatível com defeito do desenvolvimento sexual ovotesticular, foi realizada a biópsia gonadal que revelou a presença de testículos normais para a idade bilateralmente. O paciente também foi submetido ao seguimento preconizado para a SBW, com pesquisa ultrassonográfica de abdômen seriada, tendo sido identificadas lesões sugestivas de hamartoma mesenquimal hepático, estas lesões podem estar associadas à DMP (Reed et al., 2008). O núcleo familiar (pai, mãe e filho) foi genotipado com seis marcadores microssatélites específicos para o cromossomo $X$, sendo a cópia extra do cromossomo $X$ identificada como de origem paterna. Quatro marcadores para o cromossomo $Y$ indicaram a presença deste cromossomo. Outros 29 microssatélites distribuídos em 13 autossomos demonstraram a presença de diferentes complementos haploides paternos. A porcentagem de células androgenéticas foi calculada, de acordo com as áreas dos picos excedentes dos alelos paternos, e foi estimada entre $25-30 \%$.

Teoricamente, a presença de dois diferentes genomas paternos pode derivar de um espermatozóide diploide, resultante de um erro de divisão na meiose I ou II, em vez de dois espermatozóides distintos. A distinção entre estes tipos de erros pode ser feita por análise de marcadores pericentroméricos (McFadden et al., 2002; Robinson et al., 2007), pois as regiões pericentromérica possuem baixas taxas de recombinação (Matise et al., 2007). Se os dois genomas paternos forem derivados 
de um espermatozóide diploide que foi submetido a um erro na meiose I, é esperado que ambos os alelos sejam transmitidos em todos os marcadores pericentroméricos heterozigotos no pai. Em um erro na meiose II, o mesmo alelo paterno é esperado para os marcadores pericentroméricos. Se dois espermatozóides distinos estão envolvidos, a transmissão de alelos paternos pericentroméricos deve ser aleatória. No caso do paciente com DMP, a possibilidade de um erro na meiose II foi descartada, pois ele possuia cromossomos $\mathrm{X}$ e $\mathrm{Y}$ paternos. Um erro na meiose II formaria apenas gametas $\mathrm{XX}$ ou $\mathrm{YY}$. O mesmo alelo paterno foi transmitido para marcadores pericentroméricos informativos nos cromossomo 13 (D13S742), 18 (D18S1002) e 19 (D19S433) descartando também a possibilidade de um erro na meiose I. Portanto, os achados indicaram o envolvimento de dois espermatozóides distintos.

O mecanismo mais provável de formação neste caso foi a fertilização de um oócito por dois espermatozóides, seguido por uma divisão em uma célula filha diploide com um genoma biparental e uma célula filha com um genoma haploide paterno e, posteriormente, reduplicação mitótica do genoma haploide paterno (Kotzot 2008). É possível também que tenha ocorrido um evento de diplodização de triploide (Golubovsky, 2003). Um mecanismo que tem sido proposto é a fertilização de dois diferentes oócitos (um normal, fertilizado por um espermatozóide contendo um cromossomo $\mathrm{Y}$ e um oócito vazio fertilizado por um espermatozóide contendo um cromossomo X, com duplicação do conjunto haplóide) e a fusão de dois zigotos em uma mórula quimérica (Morales et al., 2009), mas este modelo é improvável pois não há evidência convincente da existência de oócitos anucleados (Golubovsky, 2003; Rosembusch, 2009).

Os exemplos na literatura de mosaicismo androgenético/biparental são raros e geralmente publicados como relatos de caso (Giurgea et al. 2006; Robinson et al. 2007; Reed et al., 2008; Wilson et al. 2008; Morales et al. 2009; Romanelli et al., 2011; Yamazawa et al., 2011). Na maioria dos casos, o cariótipo observado é 46,XX ou 46, $X Y$ com diferentes manifestações clínicas. O cariótipo 46, $X X / 46, X Y$ tem sido observado exclusivamente na placenta (Surti et al., 2005; Morales et al., 2009).

Em 2008, Reed e colaboradores relataram pela primeira vez a presença de mosaicismo androgenético/biparental em uma amostra de hamartoma mesenquimal hepático de uma menina fenotipicamente normal, que também apresentou DMP. As células androgenéticas/biparentais estavam presentes apenas no fígado e na 
placenta. Em amostras de sangue e do cordão umbilical, não foram detectadas células androgenéticas. Recentemente, um estudo mostrou que pacientes com hamartoma mesenquimal hepático aparentemente esporádico, podem possuir um mosaicismo androgenético/biparental oculto ( $\mathrm{Li}$ et al., 2011). Romanelli e colaboradores (2011) relataram uma mulher com SBW com uma alta proporção de células androgenéticas (85\%). Esta paciente desenvolveu dois tipos de tumores, um tumor de Wilms aos quatro anos de idade, e um adenoma ectópico adrenocortical aos 20 anos. Não há relato de fenótipo normal, associado com a constituição genética observada no paciente com DMP em nosso trabalho. É provável que a extensão global das alterações (epi) genéticas não excedeu o nível de limiar para a ocorrência de alterações no imprinting ou distúrbios recessivos mendelianos, necessários para o desenvolvimento de fenótipo da SBW ou de outra alteração causada pela DUPpat em outros cromossomos. O paciente apresentou metilação nas ICRs 1 e 2 nos limites da normalidade do imprinting nestas regiões. Na ICR1, o perfil de metilação observado foi de $62 \%$ e na ICR2, de $36 \%$.

Recentemente, foi relatado um caso de uma paciente com fenótipo semelhante ao da SSR, com um cariótipo em mosaico da síndrome de Turner $(45, \mathrm{X} / 46, \mathrm{XX})$. Os resultados de estudos moleculares com marcadores microssatélites para todo o genoma revelaram que a linhagem $46, X X$ foi acompanhada por isodissomia uniparental materna para todos os cromossomos, enquanto que a linhagem $45, X$ foi herdada biparentalmente com o cromossoma $X$ de origem materna. A frequência de células 46,XX em leucócitos foi de $84 \%$ (Yamazawa et al., 2010).

\subsection{Alterações epigenéticas na SSR, SBW e HHI}

Na família com duplicação na região da ICR2 (pacientes SSR 1312, SSR 1312 irmão e SSR1312 irmã), foi encontrada hipermetilação desta região como previamente descrito (Bonaldi et al. 2011). Nos demais pacientes com SSR, a alteração epigenética encontrada foi a hipometilação na ICR1 em $25 \%$ dos casos. A frequência deste tipo de epimutação na SSR ocorre, em média, em $44 \%$ dos casos (Eggerman, 2010), mas possui grande variação entre diferentes estudos (15-64\%) (Netchine et al., 2007; Binder et al., 2008; Bartholdi et al., 2009; Bruce et al., 2009; 
Eggerman et al., 2009; Hattori et al., 2009; Peñaherrera et al., 2010). O diagnóstico na maioria dos trabalhos é baseado apenas em DNA proveniente de amostras de sangue e não detecta mosaicismo que pode afetar outros tipos de tecidos. A grande diferença pode ser explicada, pelo menos em parte, pelos métodos distintos utilizados com diferentes sensibilidades, mas a principal razão provavelmente é a divergência dos critérios clínicos utilizados (Eggermann, 2010).

Alguns pacientes com SSR apresentam alteração de metilação em outros loci fora da ICR1 e ICR2 (Azzi et al., 2009; Turner et al., 2010), ou em ambas as ICRs (Beggerman et al., 2010). Turner e colaboradores (2010) encontraram hipermetilação no gene que codifica o receptor do fator de crescimento semelhante à insulina (IGF2R, do inglês, insulin-like growth fator 2 receptor) em sete dos 79 pacientes com suspeita de SSR, e destacaram o potencial envolvimento deste gene na SSR. Foi observada forte associação entre os níveis de metilação na ICR1 com a severidade fenotípica (Bruce et al., 2009). Características clássicas da SSR foram encontradas em pacientes com hipometilação na ICR1 e sintomas moderados, em pacientes com DUPmat para o cromossomo 7 (Bruce et al., 2009; Wakeling et al., 2010).

Uma possível participação do cromossomo $X$ na etiologia da SSR tem sido proposta (Sharp et al., 2001; Beever et al., 2003). O marcador utilizado para determinação dos padrões de inativação do cromossomo X em ambos os estudos foi publicado há 20 anos (Allen et al., 1992) e continua sendo um dos artigos mais citados na área de inativação do cromossomo $X$, com mais de 1100 citações no banco de dados do ISI Web of Knowledge (acesso em 7 de junho de 2011). Este marcador é um microssatélite do tipo trinucleotídeo no éxon 1 do gene que codifica o receptor de andrógenos ( $A R$, do inglês, Androgen Receptor),e está próximo a sítios diferencialmente metilados entre os cromossomos $X$ ativo e inativo. Com o uso de enzimas sensíveis a metilação, é possível verificar a aleatoriedade da inativação do cromossomo X, comparando-se as áreas dos picos gerados por eletroforese capilar nas mulheres heterozigotas, antes e após a digestão do DNA genômico. A heterozigose para este marcador é de aproximadamente $85 \%$, portanto, para $15 \%$ das mulheres este marcador não é informativo. Este marcador também apresenta altas taxas de produtos stutter e a expansão do polimorfismo causa a doença de Kennedy (Monks et al., 2008), caracterizada por degeneração de neurônios motores espinhais e bulbares. Durante o desenvolvimento do presente estudo, foi descoberto 
um novo marcador para estudos da inativação do cromossomo $X$ com a mesma informatividade do marcador no gene $A R$, mas sem as características indesejáveis deste marcador. Este trabalho foi iniciado no Brasil e finalizado no Leiden University Medical Center, em Leiden-Holanda, com bolsa sanduiche concedida pelo Programa CAPES-NUFFIC (Projeto: Estudo Colaborativo Brasil-Holanda de Compensação de Dose em Animais e Humanos) entre abril e agosto de 2011. O artigo submetido está nos anexos. O novo marcador será importante para estudos futuros de associação entre a inativação do cromossomo $X$ e a SSR, assim como poderá ser utilizado como um marcador epigenético de uma grande variedade de doenças humanas, como o câncer e doenças recessivas e dominantes ligadas ao cromossomo $X$.

Nos pacientes com $\mathrm{HHI}$, as alteração epigenéticas encontradas foram a hipermetilação da ICR1 concomitante com a hipometilação da ICR2 nos dois pacientes que apresentaram DUPpat do cromossomo 11 (13\% dos casos). Os níveis de metilação foram influenciados pela quantidade de células com mosaicismo androgenético. Nenhuma outra alteração epigenética foi observada nos demais pacientes. Um estudo realizado com 51 pacientes com $\mathrm{HHI}$, mostrou em 16\% dos casos a presença de DUPpat Cr11 e em 6\%, hipometilação da ICR2 (Shuman et al. 2006). Metade dos pacientes com DUPpat Cr11 desenvolveu algum tipo de tumor, e entre esses pacientes sem alteração molecular detectada, 15\% foram afetados por neoplasia. Os tumores mais frequentes foram tumor de Wilms e hepatoblastoma. Bliek e colaboradores (2008) observaram que $10 \%$ dos pacientes com $\mathrm{HHI}$ desenvolveram tumores na infância, sendo que na metade dos casos foi observada DUPpat Cr11 É interessante notar, que a maior alteração no perfil de metilação nas ICRs 1 e 2 encontrada no nosso trabalho foi em um paciente com HHI. Os altos índices de DUPpat Cr11 alteraram significativamente o perfil de metilação nas ICRs 1 (93\%) e 2 (5\%). O paciente, com 14 anos e alta estaura, foi consultado recentemente e até o momento, com a idade de 14 anos não desenvolveu nenhum tipo de tumor. Pelo contrário, apresentou melhora na assimetria corporal. Nem sempre a alteração epigenética causa uma alteração fenotípica aparente. Alterações (epi) genéticas foram observadas em DNA de linfócitos de pacientes com tumor de Wilms esporádico, sem características de doenças relacionadas ao crescimento, em $3 \%$ dos casos (Scott et al., 2008). Em quase metade desses pacientes a alteração encontrada foi a DUPpat Cr11 e na outra metade foi observada hipermetilação na ICR1. 
A alteração epigenética mais frequente na SBW foi a hipometilação na ICR2 em $42 \%$ dos casos. A hipermetilação na ICR1 e hipometilação na ICR2 conjunta devido à DUPpat Cr11 foi observada em 19\% dos pacientes. Hipermetilação isolada na ICR1 foi detectada em 6\% dos casos. Estes achados estão de acordo com as alterações encontradas em diferentes estudos revisados por Wersberg e colaboradores (2010) e Gicquel e colaboradores (2012). As alterações (epi) genéticas encontradas em nosso estudo assemelham-se mais às alterações encontradas em pacientes da América do Norte e Europa, do que às encontradas em pacientes japoneses (Sasaki et al., 2007).

Para a análise de uma sonda na ICR2 do ensaio de MS-MLPA, o paciente com a duplicação paterna apresentou hipermetilação. Na replicata biológica, a mesma sonda apresentou hipermetilação novamente. As outras três sondas adjacentes apresentaram hipometilação. Se todas as sondas em conjunto forem avaliadas, o perfil de metilação é considerado normal (42\%), se a sonda indicando hipermetilação for retirada, o perfil é de hipometilação (33\%). Utilizando diferentes pontos CpG com o ensaio de DESM-RT, o perfil de metilação para este paciente foi normal (49\%). Pode ser que exista algum mecanismo de compensação da metilação na ICR2 neste caso de duplicação paterna e que o fenótipo observado pode ser devido apenas à hipermetilação na ICR1. Uma forma de testar essas hipóteses seria observando a expressão de genes controlados pela ICR2 neste paciente.

$\mathrm{Na}$ SBW, como na HHI, o risco para o desenvolvimento de tumores é maior em pacientes com DUPpat Cr11 e hipermetilação na ICR1 (Gaston et al., 2001; Weksberg et al., 2001). O tumor de Wilms é o mais frequente em casos de DUPpat Cr11 e hipermetilação na ICR1, e não foi observado em casos de hipometilação na ICR2, que pode causar o desenvolvimento de diferentes tipos de tumores (Weksberg et al., 2001).

Alguns pacientes foram selecionados para comparação do perfil de metilação entre os ensaios de MS-MLPA com o ensaio de DESM-RT descrito anteriormente pelo grupo (Gomes et al., 2007). Os resultados foram altamente correlacionados entre os ensaios $(\rho=0,94)$. O ensaio de DESM-RT foi realizado com triplicata amostral. O ensaio de DESM-RT foi considerado apenas quando os resultados das triplicatas foi homogêneo. A distância física entre o $\mathrm{CpG}$ da sonda mais próxima do MS-MLPA, para os dois CpGs avaliados por DESM-RT na ICR2 é de apenas 60 nucleotídeos para o primeiro CpG e 84 nucleotídeos para o segundo., 
respectivamente. É importante que uma amostra com perfil de metilação caracterizado por MS-MLPA seja incluída nos ensaios de DESM-RT para esta região, uma vez que essa conduta pode ser importante em casos de discrepância entre resultados de placas de qPCR.

\subsection{Novo ensaio de DESM-QFPCR}

Várias metodologias quantitativas têm sido utilizadas para verificação de alterações epigenéticas nas ICRs1 e 2 (Gomes et al., 2007; Schonherr et al., 2007; Scott et al., 2008; Alders et al., 2009; Romanelli et al., 2011). Os ensaios são baseados na modificação prévia do DNA com bissulfito de sódio (composto químico que converte in vitro as citosinas não metiladas presentes na molécula de DNA em uracil), ou são digeridos previamente com enzima de restrição sensível à metilação. Ao contrário da DESM-RT, em que se mede a metilação na fase exponencial da PCR, a MS-MLPA mede a quantidade de metilação na fase final da PCR ou fase platô (Kainz, 2000). Estudos com MS-PCR (PCR específica para a metilação, do inglês methylation specific PCR) associada à QF-PCR têm sido descritos (Cooper et al., 2005; Schonherr et al., 2007), mas o ensaio requer a modificação prévia do DNA com bissulfito de sódio.

No presente trabalho, foi desenvolvido um novo ensaio baseado na DESM associada à QF-PCR para quantificação da metilação nas ICRs 1 e 2. Apesar do número de indivíduos testados ter sido pequeno $(n=8)$, foram escolhidos indivíduos com diferentes padrões de metilação nas ICRs 1 e 2, estabelecidos por MS-MLPA. Para a ICR2 o coeficiente de correlação foi muito alto $(\rho=0,96)$ demonstrando que este ensaio pode ser utilizado em conjunto com outra forma de quantificação dos padrões de imprinting na ICR2, para complementação e validação dos resultados.

O ensaio de MLPA é laborioso e de custo relativamente alto., Portanto, este novo ensaio pode ser utilizado para confirmar os dados de MLPA como controle das replicatas biológicas dos pacientes investigados. Apesar do ensaio comercial de MSMLPA possuir mais de 40 sondas, apenas quatro são utilizadas para verificação do perfil de metilação na ICR 1, e mais quatro na ICR 2. Cada sonda mede o nível de metilação de apenas um ponto CpG, e está limitado a determinar a metilação em 
pontos GCGC pois este é o sítio da enzima Hhal, a única possível para ser utilizada no ensaio.

No amplicon do novo ensaio desenvolvido para a ICR 2, estão presentes diferentes sítios de clivagem para enzimas sensíveis à metilação, comumente utilizadas: um sítio para a enzima Hpall, três para a enzima Hhal e dois para a enzima Bstul. Portanto, o ensaio pode fornecer informação de cinco sítios CpG dentro da ICR2. Preliminarmente neste estudo, foram comparados os dados do ensaio MS-MLPA com o nível de metilação no sítio da enzima Hpall. No entanto, este novo ensaio possibilita as análises futuras com outras enzimas.

Para a ICR1, não foi obtida uma correlação entre os resultados do MS-MLPA com a DESM-QFPCR. Foram investigados dois GpGs em diferentes sítios da enzima Hpall para este amplicon. Pode ser que estes pontos não representem os $50 \%$ de metilação esperado, visto que o nível de metilação de cada CpG dentro da mesma ilha CpG pode variar ( Frost et al., 2010).

\subsection{Minissequenciamento de SNPs}

Os ensaios para inferir níveis de expressão geralmente são baseados na metilação do DNA como uma maneira indireta de inferir a expressão gênica. Tem sido demonstrado que os padrões de metilação nem sempre refletem a expressão gênica esperada (Frost et al., 2010).

Os SNPs foram validados como uma ferramenta para quantificar alterações como DUP e duplicações. A genotipagem de SNPs foi conduzida em reações separadas, mas o ensaio foi desenhado para funcionar em sistema multiplex, a partir de primers com diferentes tamanhos de amplicons. No entanto, novas tentativas de montagem do sistema multiplex serão necessárias no futuro.

A informatividade dos SNPs nos genes H19 e IGF2 já eram conhecidas na população brasileira em um estudo do grupo (Soares et al., 2010), mas a informatividade dos dois SNPs investigados no gene KCNQ1OT1 não era conhecida. Apesar do baixo número de indivíduos testados $(n=12)$, os SNPs neste gene mostraram alta taxa de heterozigose de 55\% e 41\%. É importante salientar que a informatividade combinada, ou seja, heterozigose para pelo menos um dos dois marcadores no gene KCNQ1OT1 foi de $83 \%$. 
Este ensaio foi idealizado para genotipar cDNA de pacientes com alteração de imprinting nas ICRs 1 e 2, levando-se em conta que a principal alteração epigenética observada na BWS é a hipometilação da ICR2, a qual leva à expressão bialélica do KCNQ1OT1. Apesar de ter sido mostrado que essa expressão bialélica em sangue de adultos fenotipicamente normais (Frost et al., 2010), a quantificação da expressão dos alelos maternos e paternos não tem sido discutida. Com este ensaio, acredita-se que será possível diferenciar quantitativamente o escape do alelo materno em indivíduos com hipometilação na ICR2, comparado ao grupo controle.

Cerca de $5-10 \%$ dos casos de SBW é devido à hipermetilação da ICR1 (Weksberg et al. 2010), levando a expressão bialélica do gene IGF2. Metade dos indivíduos testados com o SNP no gene IGF2 foi informativa. Portanto, com este ensaio será possível quantificar o escape do alelo materno que deveria estar silenciado. A hipometilação da ICR1 está presente em aproximadamente $44 \%$ dos pacientes SSR (Eggerman, 2010). A hipometilação desta região causa expressão bialélica do gene imprinted H19. O SNP investigado no gene H19 foi o menos informativo, sendo que apenas três indivíduos em 10 apresentaram heterozigose para este marcador. O ensaio foi desenvolvido para medir o escape do H19 paterno nos casos de hipometilação da ICR1 nos pacientes com SSR.

Recentemente, alguns estudos baseados em células com diferentes proporções de componentes genéticos paternos e maternos mostraram novas regiões diferencialmente metiladas no genoma humano associadas à genes imprinted (Choufani et al., 2011; Nakabayashi et al., 2011; Yuen et al., 2011). Também foi detectada uma nova região diferencialmente metilada na região promotora do gene CDKN1C (Yuen et al., 2011). Alteração da metilação desta nova região ainda não foi investigada, e pode exercer um papel importante na etiologia da SSR, HHI e SBW. Essas novas descobertas mostram a complexidade da etiologia das doenças estudadas no presente trabalho e quanto ainda há para ser descoberto.O presente estudo abre novas perspectivas de pesquisas, principalmente quanto à avaliação da expressão gênica em indivíduos com alteração das ICRs 1 e 2; sequenciamento do gene CDKN1C em pacientes que apresentaram metilação normal nas ICRs 1 e 2; verificação de microdeleções/duplicações na ICR1 de pacientes com hipermetilação nesta região. A correlação dos dados moleculares com os achados clínicos são muito importantes, não só para a pesquisa da etiologia 
e do esclarecimento dos mecanismos normais do desenvolvimento, mas também para a disponibilização de aconselhamento genético adequado para cada caso em particular e suas famílias. 


\section{CONCLUSÕES}

- Doze novos marcadores microssatélites para o cromossomo 11 e quatro para o cromossomo 7 foram validados para verificação de alterações estruturais e dissomia uniparental, em pacientes com SSR, SBW e HHI.

- A dissomia uniparental foi restrita ao braço curto do cromossomo 11 nos paciente com SBW e HHI. A dissomia uniparental global não é comum nas SBW e HHI.

- Mosaicismo global com células androgenéticas e bibarentais foi encontrado em um paciente fenotipicamente normal com cariótipo $46, X X / 46, X Y$, que apresentou displasia mesenquimal placentária,.

- Um novo ensaio baseado na QF-PCR foi desenvolvido para determinação do perfil de metilação na ICR2.

- O perfil de metilação na ICR2 foi avaliado por três diferentes metodologias com valores altamente concordantes.

- O perfil de metilação na ICR1 foi avaliado por duas diferentes metodologias com valores altamente concordantes.

- As frequências de alterações (epi) genéticas encontradas foram semelhantes às previamente descritas na literatura para as SBW, SSR e HHI.

- Uma deleção não descrita anteriormente no gene CDKN1C foi observada em um paciente e sua mãe.

- Os SNPs nos genes marcados (imprinted) IGF2, H19 e KCNQ1OT1 foram altamente informativos e poderão ser utilizados futuramente em experimentos com cDNA de pacientes com alterações epigenéticas nas ICRs 1 e 2 . 


\section{REFERÊNCIAS}

ABU-AMERO, S., MONK, D., FROST, J., PREECE, M., STANIER, P., MOORE, G.E. (2008). The genetic aetiology of Silver-Russell syndrome. J Med Genet 45, 193-199.

ALDERS, M., BLIEK, J., VD LIP, K., VD BOGAARD, R., MANNENS, M. (2009). Determination of KCNQ1OT1 and H19 methylation levels in BWS and SRS patients using methylation-sensitive high-resolution melting analysis. Eur $\mathrm{J}$ Hum Genet 17, 467-473.

ALGAR, E.M., ST HEAPS, L., DARMANIAN, A., DAGAR, V., PRAWITT, D., PETERS, G.B., COLLINS, F. (2007). Paternally inherited submicroscopic duplication at 11p15.5 implicates insulin-like growth factor II in overgrowth and Wilms' tumorigenesis. Cancer Res 67, 2360-2365.

ALLEN, R.C., ZOGHBI, H.Y., MOSELEY, A.B., ROSENBLATT, H.M., BELMONT, J.W. (1992). Methylation of Hpall and Hhal sites near the polymorphic CAG repeat in the human androgen-receptor gene correlates with $\mathrm{X}$ chromosome inactivation. Am J Hum Genet 51, 1229-1239.

ANG, D.C., RODRIGUEZ URREGO, P.A., PRASAD, V. (2009). Placental mesenchymal dysplasia: a potential misdiagnosed entity. Arch Gynecol Obstet 279, 937-939.

ARBOlEDA, V.A., LEE, H., PARNAIK, R., FLEMING, A., BANERJEE, A., FERRAZDE-SOUZA, B., DELOT, E.C., RODRIGUEZ-FERNANDEZ, I.A., BRASLAVSKY, D., BERGADA, I., DELL'ANGELICA, E.C., NELSON, S.F., MARTINEZ-AGOSTO, J.A., ACHERMANN, J.C., and VILAIN, E. (2012). Mutations in the PCNA-binding domain of CDKN1C cause IMAGe syndrome. Nat Genet.

AZZI, S., ROSSIGNOL, S., STEUNOU, V., SAS, T., THIBAUD, N., DANTON, F., LE JULE, M., HEINRICHS, C., CABROL, S., GICQUEL, C., LE BOUC, Y., NETCHINE, I. (2009). Multilocus methylation analysis in a large cohort of 11p15-related foetal growth disorders (Russell Silver and Beckwith Wiedemann syndromes) reveals simultaneous loss of methylation at paternal and maternal imprinted loci. Hum Mol Genet 18, 4724-4733.

BARTHOLDI, D., KRAJEWSKA-WALASEK, M., OUNAP, K., GASPAR, H., CHRZANOWSKA, K.H., ILYANA, H., KAYSERILI, H., LURIE, I.W., SCHINZEL, A., BAUMER, A. (2009). Epigenetic mutations of the imprinted IGF2-H19 domain in Silver-Russell syndrome (SRS): results from a large cohort of patients with SRS and SRS-like phenotypes. J Med Genet 46, 192197.

BARTON, S.C., SURANI, M.A., NORRIS, M.L. (1984). Role of paternal and maternal genomes in mouse development. Nature 311, 374-376.

BAUJAT, G., RIO, M., ROSSIGNOL, S., SANLAVILLE, D., LYONNET, S., LE MERRER, M., MUNNICH, A., GICQUEL, C., COLLEAUX, L., CORMIER- 
DAIRE, V. (2005). Clinical and molecular overlap in overgrowth syndromes. Am J Med Genet C Semin Med Genet 137C, 4-11.

BEEVER, C.L., PENAHERRERA, M.S., LANGLOIS, S., ROBINSON, W.R. (2003). X chromosome inactivation patterns in Russell-Silver syndrome patients and their mothers. Am J Med Genet A 123A, 231-235.

BEGEMANN, M., SPENGLER, S., KANBER, D., HAAKE, A., BAUDIS, M., LEISTEN, I., BINDER, G., MARKUS, S., RUPPRECHT, T., SEGERER, H., FRICKEOTTO, S., MUHLENBERG, R., SIEBERT, R., BUITING, K., EGGERMANN, T. (2011). Silver-Russell patients showing a broad range of ICR1 and ICR2 hypomethylation in different tissues. Clin Genet 80, 83-88.

BENSON, G. (1999). Tandem repeats finder: a program to analyze DNA sequences. Nucleic Acids Res 27, 573-580.

BINDER, G., SEIDEL, A.K., MARTIN, D.D., SCHWEIZER, R., SCHWARZE, C.P., WOLLMANN, H.A., EGGERMANN, T., RANKE, M.B. (2008). The endocrine phenotype in silver-russell syndrome is defined by the underlying epigenetic alteration. J Clin Endocrinol Metab 93, 1402-1407.

BLIEK, J., MAAS, S., ALDERS, M., MERKS, J.H., MANNENS, M. (2008). Epigenotype, phenotype, and tumors in patients with isolated hemihyperplasia. J Pediatr 153, 95-100.

BLIEK, J., MAAS, S.M., RUIJTER, J.M., HENNEKAM, R.C., ALDERS, M., WESTERVELD, A., MANNENS, M.M. (2001). Increased tumour risk for BWS patients correlates with aberrant $\mathrm{H} 19$ and not KCNQ1OT1 methylation: occurrence of KCNQ1OT1 hypomethylation in familial cases of BWS. Hum Mol Genet 10, 467-476.

BLIEK, J., SNIJDER, S., MAAS, S.M., POLSTRA, A., VAN DER LIP, K., ALDERS, M., KNEGT, A.C., MANNENS, M.M. (2009). Phenotypic discordance upon paternal or maternal transmission of duplications of the $11 \mathrm{p} 15$ imprinted regions. Eur J Med Genet 52, 404-408.

BONALDI, A., MAZZEU, J.F., COSTA, S.S., HONJO, R.S., BERTOLA, D.R., ALBANO, L.M., FURQUIM, I.M., KIM, C.A., VIANNA-MORGANTE, A.M. (2011). Microduplication of the ICR2 domain at chromosome 11p15 and familial Silver-Russell syndrome. Am J Med Genet A 155A, 2479-2483.

BRUCE, S., HANNULA-JOUPPI, K., PELTONEN, J., KERE, J., LIPSANEN-NYMAN, M. (2009). Clinically distinct epigenetic subgroups in Silver-Russell syndrome: the degree of $\mathrm{H} 19$ hypomethylation associates with phenotype severity and genital and skeletal anomalies. J Clin Endocrinol Metab 94, 579-587.

BULLMAN, H., LEVER, M., ROBINSON, D.O., MACKAY, D.J., HOLDER, S.E., WAKELING, E.L. (2008). Mosaic maternal uniparental disomy of chromosome 11 in a patient with Silver-Russell syndrome. J Med Genet 45, 396-399.

BUSQUE, L., PAQUETTE, Y., PROVOST, S., ROY, D.C., LEVINE, R.L., MOLLICA, L., GILLILAND, D.G. (2009). Skewing of X-inactivation ratios in blood cells of 
aging women is confirmed by independent methodologies. Blood 113, 34723474.

CATCHPOOLE, D., LAM, W.W., VALLER, D., TEMPLE, I.K., JOYCE, J.A., REIK, W., SCHOFIELD, P.N., MAHER, E.R. (1997). Epigenetic modification and uniparental inheritance of $\mathrm{H} 19$ in Beckwith-Wiedemann syndrome. J Med Genet 34, 353-359.

CerRAto, F., SPARAGo, A., VERDE, G., DE CRESCENZO, A., CitRo, V., CUBELLIS, M.V., RINALDI, M.M., BOCCUTO, L., NERI, G., MAGNANI, C., D'ANGElO, P., COLliNI, P., PEROTTI, D., SEBASTIO, G., MAHER, E.R., RICCIO, A. (2008). Different mechanisms cause imprinting defects at the IGF2/H19 locus in Beckwith-Wiedemann syndrome and Wilms' tumour. Hum Mol Genet 17, 1427-1435.

CHEN, Z.X., RIGGS, A.D. (2011). DNA methylation and demethylation in mammals. J Biol Chem 286, 18347-18353.

CHOUFANI, S., SHAPIRO, J.S., SUSIARJO, M., BUTCHER, D.T., GRAFODATSKAYA, D., LOU, Y., FERREIRA, J.C., PINTO, D., SCHERER, S.W., SHAFFER, L.G., COULLIN, P., CANIGGIA, I., BEYENE, J., SLIM, R., BARTOLOMEI, M.S., WEKSBERG, R. (2011). A novel approach identifies new differentially methylated regions (DMRs) associated with imprinted genes. Genome Res 21, 465-476.

CHOUFANI, S., SHUMAN, C.,WEKSBERG, R. (2010). Beckwith-Wiedemann syndrome. Am J Med Genet C Semin Med Genet 154C, 343-354.

COOPER, W.N., CURLEY, R., MACDONALD, F., MAHER, E.R. (2007). Mitotic recombination and uniparental disomy in Beckwith-Wiedemann syndrome. Genomics 89, 613-617.

COOPER, W.N., LUHARIA, A., EVANS, G.A., RAZA, H., HAIRE, A.C., GRUNDY, R., BOWDIN, S.C., RICCIO, A., SEBASTIO, G., BLIEK, J., SCHOFIELD, P.N., REIK, W., MACDONALD, F., MAHER, E.R. (2005). Molecular subtypes and phenotypic expression of Beckwith-Wiedemann syndrome. Eur J Hum Genet 13, 1025-1032.

DAS, S., LESE, C.M., SONG, M., JENSEN, J.L., WELLS, L.A., BARNOSKI, B.L., ROSEBERRY, J.A., CAMACHO, J.M., LEDBETTER, D.H., CHNUR, R.E. (2000). Partial paternal uniparental disomy of chromosome 6 in an infant with neonatal diabetes, macroglossia, and craniofacial abnormalities. Am J Hum Genet 67, 1586-1591.

DE CRESCENZO, A., COPPOLA, F., FALCO, P., BERNARDO, I., AUSANIO, G., CERRATO, F., FALCO, L., RICCIO, A. (2011). A novel microdeletion in the IGF2/H19 imprinting centre region defines a recurrent mutation mechanism in familial Beckwith-Wiedemann syndrome. Eur J Med Genet 54, e451-454.

DEATON, A.M., BIRD, A. (2011). CpG islands and the regulation of transcription. Genes Dev 25, 1010-1022. 
DEMARS, J., GICQUEL, C. (2012). Epigenetic and genetic disturbance of the imprinted $11 \mathrm{p} 15$ region in Beckwith-Wiedemann and Silver-Russell syndromes. Clin Genet 81, 350-361.

DEMARS, J., ROSSIGNOL, S., NETCHINE, I., LEE, K.S., SHMELA, M., FAIVRE, L., WEILL, J., ODENT, S., AZZI, S., CALLIER, P., LUCAS, J., DUBOURG, C., ANDRIEUX, J., LE BOUC, Y., EL-OSTA, A., GICQUEL, C. (2011). New insights into the pathogenesis of Beckwith-Wiedemann and Silver-Russell syndromes: contribution of small copy number variations to $11 \mathrm{p} 15$ imprinting defects. Hum Mutat 32, 1171-1182.

DEMARS, J., SHMELA, M.E., ROSSIGNOL, S., OKABE, J., NETCHINE, I., AZZI, S., CABROL, S., LE CAIGNEC, C., DAVID, A., LE BOUC, Y., EL-OSTA, A., GICQUEL, C. (2010). Analysis of the IGF2/H19 imprinting control region uncovers new genetic defects, including mutations of OCT-binding sequences, in patients with 11p15 fetal growth disorders. Hum Mol Genet 19, 803-814.

DUTLY, F., BAUMER, A., KAYSERILI, H., YUKSEL-APAK, M., ZEROVA, T., HEBISCH, G., SCHINZEL, A. (1998). Seven cases of Wiedmann-Beckwith syndrome, including the first reported case of mosaic paternal isodisomy along the whole chromosome 11. Am J Med Genet 79, 347-353.

EGGERMANN, T. (2009). Silver-Russell and Beckwith-Wiedemann syndromes: opposite (epi)mutations in 11 p15 result in opposite clinical pictures. Horm Res 71 Suppl 2, 30-35.

EGGERMANN, T. (2010). Russell-Silver syndrome. Am J Med Genet C Semin Med Genet 154C, 355-364.

EGGERMANN, T., BEGEMANN, M., BINDER, G., and SPENGLER, S. (2010). Silver-Russell syndrome: genetic basis and molecular genetic testing. Orphanet J Rare Dis 5, 19.

EGgermanN, T., MEYER, E., OBERMANN, C., HEIL, I., SCHULER, H., RANKE, M.B., EGGERMANN, K., WOLLMANN, H.A. (2005). Is maternal duplication of 11 p15 associated with Silver-Russell syndrome? J Med Genet 42, e26.

EGGERMANN, T., WOLLMANN, H.A., KUNER, R., EGGERMANN, K., ENDERS, H., KAISER, P., RANKE, M.B. (1997). Molecular studies in 37 Silver-Russell syndrome patients: frequency and etiology of uniparental disomy. Hum Genet 100, 415-419.

ENGEL, E. (1980). A new genetic concept: uniparental disomy and its potential effect, isodisomy. Am J Med Genet 6, 137-143.

ENGEL, E. (2006). A fascination with chromosome rescue in uniparental disomy: Mendelian recessive outlaws and imprinting copyrights infringements. Eur $\mathrm{J}$ Hum Genet 14, 1158-1169.

ENKLAAR, T., ZABEL, B.U., PRAWITT, D. (2006). Beckwith-Wiedemann syndrome: multiple molecular mechanisms. Expert Rev Mol Med 8, 1-19. 
FAN, H., CHU, J.Y. (2007). A brief review of short tandem repeat mutation. Genomics Proteomics Bioinformatics 5, 7-14.

FERGUSON-SMITH, A.C. (2011). Genomic imprinting: the emergence of an epigenetic paradigm. Nat Rev Genet 12, 565-575.

FISHER, A.M., THOMAS, N.S., COCKWELL, A., STECKO, O., KERR, B., TEMPLE, I.K., CLAYTON, P. (2002). Duplications of chromosome 11p15 of maternal origin result in a phenotype that includes growth retardation. Hum Genet 111, 290-296.

FROST, J.M., MONK, D., STOJILKOVIC-MIKIC, T., WOODFINE, K., CHITTY, L.S., MURRELL, A., STANIER, P., MOORE, G.E. (2010). Evaluation of allelic expression of imprinted genes in adult human blood. PLoS One 5, e13556.

FUKE-SATO, T., YAMAZAWA, K., NAKABAYASHI, K., MATSUBARA, K., MATSUOKA, K., HASEGAWA, T., DOBASHI, K., OGATA, T. (2012). Mosaic upd(7)mat in a patient with Silver-Russell syndrome. Am J Med Genet A 158A, 465-468.

GASTON, V., LE BOUC, Y., SOUPRE, V., BURGLEN, L., DONADIEU, J., ORO, H., AUDRY, G., VAZQUEZ, M.P., GICQUEL, C. (2001). Analysis of the methylation status of the KCNQ1OT and H19 genes in leukocyte DNA for the diagnosis and prognosis of Beckwith-Wiedemann syndrome. Eur J Hum Genet 9, 409-418.

GIARDINA, E., PECONI, C., CASCELLA, R., SINIBALDI, C., FOTI CUZZOLA, V., NARDONE, A.M., BRAMANTI, P., and NOVELLI, G. (2009). A multiplex molecular assay for the detection of uniparental disomy for human chromosome 7. Electrophoresis 30, 2008-2011.

GIURGEA, I., SANLAVILLE, D., FOURNET, J.C., SEMPOUX, C., BELLANNECHANTELOT, C., TOUATI, G., HUBERT, L., GROOS, M.S., BRUNELLE, F., RAHIER, J., HENQUIN, J.C., DUNNE, M.J., JAUBERT, F., ROBERT, J.J., NIHOUL-FEKETE, C., VEKEMANS, M., JUNIEN, C., DE LONLAY, P. (2006). Congenital hyperinsulinism and mosaic abnormalities of the ploidy. J Med Genet 43, 248-254.

GOLUBOVSKY, M.D. (2003). Postzygotic diploidization of triploids as a source of unusual cases of mosaicism, chimerism and twinning. Hum Reprod 18, 236242.

GOMES, M.V., RAMOS, E.S. (2003). Beckwith-Wiedemann syndrome and isolated hemihyperplasia. Sao Paulo Med J 121, 133-138.

GOMES, M.V., SANTOS, S.A., RAMOS, E.S. (2005) H19DMR methylation analysis in patients with Beckwith-Wiedemann syndrome and isolated hemihyperplasia. Genet. Mol. Biol [online] 28, 210-213. 
GOMES, M.V., GOMES, C.C., PINTO, W., JR., RAMOS, E.S. (2007). Methylation pattern at the KvDMR in a child with Beckwith-Wiedemann syndrome conceived by ICSI. Am J Med Genet A 143, 625-629.

GOMES, M.V., HUBER, J., FERRIANI, R.A., AMARAL NETO, A.M., RAMOS, E.S. (2009). Abnormal methylation at the KvDMR1 imprinting control region in clinically normal children conceived by assisted reproductive technologies. Mol Hum Reprod 15, 471-477.

GRATI, F.R., TUROLlA, L., D'AJELLO, P., RUGGERI, A., MIOZZO, M., BRACALENTE, G., BALDO, D., LAURINO, L., BOLDORINI, R., FRATE, E., SURICO, N., LARIZZA, L., MAGGI, F., SIMONI, G. (2007). Chromosome 11 segmental paternal isodisomy in amniocytes from two fetuses with omphalocoele: new highlights on phenotype-genotype correlations in Beckwith-Wiedemann syndrome. J Med Genet 44, 257-263.

GRONSKOV, K., POOLE, R.L., HAHNEMANN, J.M., THOMSON, J., TUMER, Z., BRONDUM-NIELSEN, K., MURPHY, R., RAVN, K., MELCHIOR, L., DEDIC, A., DOLMER, B., TEMPLE, I.K., BOONEN, S.E., ACKAY, D.J. (2011). Deletions and rearrangements of the H19/IGF2 enhancer region in patients with Silver-Russell syndrome and growth retardation. J Med Genet 48, 308311.

GUO, H., LV, Y., TIAN, T., HU, T.H., WANG, W.J., SUI, X., JIANG, L., RUAN, Z.P., NAN, K.J. (2011). Downregulation of p57 accelerates the growth and invasion of hepatocellular carcinoma. Carcinogenesis 32, 1897-1904.

HALLIDAY, J., OKE, K., BREHENY, S., ALGAR, E., D, J.A. (2004). BeckwithWiedemann syndrome and IVF: a case-control study. Am J Hum Genet 75, 526-528.

HANNULA, K., KERE, J., PIRINEN, S., HOLMBERG, C., and LIPSANEN-NYMAN, M. (2001). Do patients with maternal uniparental disomy for chromosome 7 have a distinct mild Silver-Russell phenotype? J Med Genet 38, 273-278.

HARK, A.T., SCHOENHERR, C.J., KATZ, D.J., INGRAM, R.S., LEVORSE, J.M., TILGHMAN, S.M. (2000). CTCF mediates methylation-sensitive enhancerblocking activity at the H19/lgf2 locus. Nature 405, 486-489.

HATTORI, M., TORII, C., YAGIHASHI, T., IZUMI, K., SUDA, N., OHYAMA, K., TAKAHASHI, T., MORIYAMA, K., KOSAKI, K. (2009). Diagnosis of RussellSilver syndrome by the combined bisulfite restriction analysis-denaturing highperformance liquid chromatography assay. Genet Test Mol Biomarkers 13, 623-630.

HENRY, I., BONAITI-PELLIE, C., CHEHENSSE, V., BELDJORD, C., SCHWARTZ, C., UTERMANN, G., JUNIEN, C. (1991). Uniparental paternal disomy in a genetic cancer-predisposing syndrome. Nature 351, 665-667.

H'MIDA, D., GRIBAA, M., YACOUBI, T., CHAIEB, A., ADALA, L., ELGHEZAL, H., SAAD, A. (2008). Placental mesenchymal dysplasia with beckwith-wiedemann 
syndrome fetus in the context of biparental and androgenic cell lines. Placenta 29, 454-460.

HORSTHEMKE, B. (2006). Epimutations in human disease. Curr Top Microbiol Immunol 310, 45-59.

HORSTHEMKE, B. (2010). Mechanisms of imprint dysregulation. Am J Med Genet C Semin Med Genet 154C, 321-328.

HULTEN, M.A., DHANJAL, S., PERTL, B. (2003). Rapid and simple prenatal diagnosis of common chromosome disorders: advantages and disadvantages of the molecular methods FISH and QF-PCR. Reproduction 126, 279-297.

ILLINGWORTH, R.S., BIRD, A.P. (2009). CpG islands--'a rough guide'. FEBS Lett 583, 1713-1720.

ITOH, N., BECROFT, D.M., REEVE, A.E., MORISON, I.M. (2000). Proportion of cells with paternal 11 p15 uniparental disomy correlates with organ enlargement in Wiedemann-beckwith syndrome. Am J Med Genet 92, 111-116.

KAINZ, P. (2000). The PCR plateau phase - towards an understanding of its limitations. Biochim Biophys Acta 1494, 23-27.

KAISER-ROGERS, K.A., MCFADDEN, D.E., LIVASY, C.A., DANSEREAU, J., JIANG, R., KNOPS, J.F., LEFEBVRE, L., RAO, K.W., ROBINSON, W.P. (2006). Androgenetic/biparental mosaicism causes placental mesenchymal dysplasia. J Med Genet 43, 187-192.

KANNENBERG, K., URBAN, C., BINDER, G. (2012). Increased incidence of aberrant DNA methylation within diverse imprinted gene loci outside of IGF2/H19 in Silver-Russell syndrome. Clin Genet 81, 366-377.

KIBBE, W.A. (2007). OligoCalc: an online oligonucleotide properties calculator. Nucleic Acids Res 35, W43-46.

KONO, T., OBATA, Y., WU, Q., NIWA, K., ONO, Y., YAMAMOTO, Y., PARK, E.S., SEO, J.S., and OGAWA, H. (2004). Birth of parthenogenetic mice that can develop to adulthood. Nature 428, 860-864.

KOTZOT, D. (2008). Complex and segmental uniparental disomy updated. J Med Genet 45, 545-556.

KOTZOT, D., and UTERMANN, G. (2005). Uniparental disomy (UPD) other than 15: phenotypes and bibliography updated. Am J Med Genet A 136, 287-305.

LAM, W.W., HATADA, I., OHISHI, S., MUKAI, T., JOYCE, J.A., COLE, T.R., DONNAI, D., REIK, W., SCHOFIELD, P.N., and MAHER, E.R. (1999). Analysis of germline CDKN1C (p57KIP2) mutations in familial and sporadic Beckwith-Wiedemann syndrome (BWS) provides a novel genotype-phenotype correlation. J Med Genet 36, 518-523. 
LAU, A.W., BROWN, C.J., PENAHERRERA, M., LANGLOIS, S., KALOUSEK, D.K., ROBINSON, W.P. (1997). Skewed X-chromosome inactivation is common in fetuses or newborns associated with confined placental mosaicism. Am J Hum Genet 61, 1353-1361.

LECLERCQ, S., RIVALS, E., JARNE, P. (2007). Detecting microsatellites within genomes: significant variation among algorithms. BMC Bioinformatics 8, 125.

LI, M., SQUIRE, J., SHUMAN, C., FEI, Y.L., ATKIN, J., PAULI, R., SMITH, A., NISHIKAWA, J., CHITAYAT, D., WEKSBERG, R. (2001). Imprinting status of 11 15 genes in Beckwith-Wiedemann syndrome patients with CDKN1C mutations. Genomics 74, 370-376.

LIN, J., COLE, B.L., QIN, X., ZHANG, M., KAPUR, R.P. (2011). Occult androgeneticbiparental mosaicism and sporadic hepatic mesenchymal hamartoma. Pediatr Dev Pathol 14, 360-369.

LUEDI, P.P., DIETRICH, F.S., WEIDMAN, J.R., BOSKO, J.M., JIRTLE, R.L., HARTEMINK, A.J. (2007). Computational and experimental identification of novel human imprinted genes. Genome Res 17, 1723-1730.

MACHADO, F.B., DUARTE, L.P., MEDINA-ACOSTA, E. (2009). Improved criterionreferenced assessment in indirect tracking of haemophilia $A$ using a $0.23 \mathrm{cM}$ resolution dense polymorphic marker set. Haemophilia 15, 1135-1142.

MACHADO, F.B., MEDINA-ACOSTA, E. (2009). High-resolution combined linkage physical map of short tandem repeat loci on human chromosome band Xq28 for indirect haemophilia A carrier detection. Haemophilia 15, 297-308.

MAGNUSON, V.L., ALLY, D.S., NYLUND, S.J., KARANJAWALA, Z.E., RAYMAN, J.B., KNAPP, J.I., LOWE, A.L., GHOSH, S., COLLINS, F.S. (1996). Substrate nucleotide-determined non-templated addition of adenine by Taq DNA polymerase: implications for PCR-based genotyping and cloning. Biotechniques 21, 700-709.

MALAN, V., VEKEMANS, M., TURLEAU, C. (2006). Chimera and other fertilization errors. Clin Genet 70, 363-373.

MARTIN, R.A., GRANGE, D.K., ZEHNBAUER, B., DEBAUN, M.R. (2005). LIT1 and $\mathrm{H} 19$ methylation defects in isolated hemihyperplasia. Am J Med Genet $A$ 134A, 129-131.

MATISE, T.C., CHEN, F., CHEN, W., DE LA VEGA, F.M., HANSEN, M., HE, C., HYLAND, F.C., KENNEDY, G.C., KONG, X., MURRAY, S.S., ZIEGLE, J.S., STEWART, W.C., BUYSKE, S. (2007). A second-generation combined linkage physical map of the human genome. Genome Res 17, 1783-1786.

MCFADDEN, D.E., JIANG, R., LANGLOIS, S., ROBINSON, W.P. (2002). Dispermy-origin of diandric triploidy: brief communication. Hum Reprod 17, 3037-3038.

MCGRATH, J., SOLTER, D. (1983). Nuclear transplantation in the mouse embryo by microsurgery and cell fusion. Science 220, 1300-1302. 
MERGENTHALER, S., WOLLMANN, H.A., BURGER, B., EGGERMANN, K., KAISER, P., RANKE, M.B., SCHWANITZ, G., EGGERMANN, T. (2000). Formation of uniparental disomy 7 delineated from new cases and a UPD7 case after trisomy 7 rescue. Presentation of own results and review of the literature. Ann Genet 43, 15-21.

MONKS, D.A., RAO, P., MO, K., JOHANSEN, J.A., LEWIS, G., KEMP, M.Q. (2008). Androgen receptor and Kennedy disease/spinal bulbar muscular atrophy. Horm Behav 53, 729-740.

MORALES, C., SOLER, A., BADENAS, C., RODRIGUEZ-REVENGA, L., NADAL, A., MARTINEZ, J.M., MADEMONT-SOLER, I., BORRELL, A., MILA, M., SANCHEZ, A. (2009). Reproductive consequences of genome-wide paternal uniparental disomy mosaicism: description of two cases with different mechanisms of origin and pregnancy outcomes. Fertil Steril 92, 393 e395-399.

NAKABAYASHI, K., TRUJILLO, A.M., TAYAMA, C., CAMPRUBI, C., YOSHIDA, W., LAPUNZINA, P., SANCHEZ, A., SOEJIMA, H., ABURATANI, H., NAGAE, G., OGATA, T., HATA, K., MONK, D. (2011). Methylation screening of reciprocal genome-wide UPDs identifies novel human-specific imprinted genes. Hum Mol Genet 20, 3188-3197.

NETCHINE, I., ROSSIGNOL, S., DUFOURG, M.N., AZZI, S., ROUSSEAU, A., PERIN, L., HOUANG, M., STEUNOU, V., ESTEVA, B., THIBAUD, N., DEMAY, M.C., DANTON, F., PETRICZKO, E., BERTRAND, A.M., HEINRICHS, C., CAREL, J.C., LOEUILLE, G.A., PINTO, G., JACQUEMONT, M.L., GICQUEL, C., CABROL, S., LE BOUC, Y. (2007). 11p15 imprinting center region 1 loss of methylation is a common and specific cause of typical Russell-Silver syndrome: clinical scoring system and epigenetic-phenotypic correlations. J Clin Endocrinol Metab 92, 3148-3154.

NICHOLLS, R.D., KNOLL, J.H., BUTLER, M.G., KARAM, S., LALANDE, M. (1989). Genetic imprinting suggested by maternal heterodisomy in nondeletion Prader-Willi syndrome. Nature 342, 281-285.

OGILVIE, C.M., DONAGHUE, C., FOX, S.P., DOCHERTY, Z., MANN, K. (2005). Rapid prenatal diagnosis of aneuploidy using quantitative fluorescence-PCR (QF-PCR). J Histochem Cytochem 53, 285-288.

OKAMOTO, K., MORISON, I.M., REEVE, A.E., TOMMERUP, N., WIEDEMANN, H.R., FRIEDRICH, U. (1998). Is p57KIP2 mutation a common mechanism for Beckwith-Wiedemann syndrome or somatic overgrowth? J Med Genet 35, 86.

OLERUP, O., ZETTERQUIST, H. (1992). HLA-DR typing by PCR amplification with sequence-specific primers (PCR-SSP) in 2 hours: an alternative to serological DR typing in clinical practice including donor-recipient matching in cadaveric transplantation. Tissue Antigens 39, 225-235.

ONYANGO, P., FEINBERG, A.P. (2011). A nucleolar protein, H19 opposite tumor suppressor (HOTS), is a tumor growth inhibitor encoded by a human imprinted H19 antisense transcript. Proc Natl Acad Sci U S A 108, 16759-16764. 
PENAHERRERA, M.S., BARRETT, I.J., BROWN, C.J., LANGLOIS, S., YONG, S.L., LEWIS, S., BRUYERE, H., HOWARD-PEEBLES, P.N., KALOUSEK, D.K., ROBINSON, W.P. (2000). An association between skewed X-chromosome inactivation and abnormal outcome in mosaic trisomy 16 confined predominantly to the placenta. Clin Genet 58, 436-446.

PENAHERRERA, M.S., WEINDLER, S., VAN ALLEN, M.I., YONG, S.L., METZGER, D.L., MCGILLIVRAY, B., BOERKOEL, C., LANGLOIS, S., ROBINSON, W.P. (2010). Methylation profiling in individuals with Russell-Silver syndrome. Am J Med Genet A 152A, 347-355.

POOLE, R.L., LEITH, D.J., DOCHERTY, L.E., SHMELA, M.E., GICQUEL, C., SPLITT, M., TEMPLE, I.K., MACKAY, D.J. (2011). Beckwith-Wiedemann syndrome caused by maternally inherited mutation of an OCT-binding motif in the IGF2/H19-imprinting control region, ICR1. Eur J Hum Genet 20, 240-243.

PORTELA, A., ESTELLER, M. (2010). Epigenetic modifications and human disease. Nat Biotechnol 28, 1057-1068.

PRAWITT, D., ENKLAAR, T., GARTNER-RUPPRECHT, B., SPANGENBERG, C., OSWALD, M., LAUSCH, E., SCHMIDTKE, P., REUTZEL, D., FEES, S., LUCITO, R., KORZON, M., BROZEK, I., LIMON, J., HOUSMAN, D.E., PELLETIER, J., ZABEL, B. (2005). Microdeletion of target sites for insulator protein CTCF in a chromosome 11 p15 imprinting center in BeckwithWiedemann syndrome and Wilms' tumor. Proc Natl Acad Sci U S A 102, 4085-4090.

PRIOLO, M., SPARAGO, A., MAMMI, C., CERRATO, F., LAGANA, C., RICCIO, A. (2008). MS-MLPA is a specific and sensitive technique for detecting all chromosome 11p15.5 imprinting defects of BWS and SRS in a single-tube experiment. Eur J Hum Genet 16, 565-571.

RADFORD, E.J., FERRON, S.R., FERGUSON-SMITH, A.C. (2011). Genomic imprinting as an adaptative model of developmental plasticity. FEBS Lett 585, 2059-2066.

RAINIER, S., JOHNSON, L.A., DOBRY, C.J., PING, A.J., GRUNDY, P.E., FEINBERG, A.P. (1993). Relaxation of imprinted genes in human cancer. Nature 362, 747-749.

REED, R.C., BEISCHEL, L., SCHOOF, J., JOHNSON, J., RAFF, M.L., KAPUR, R.P. (2008). Androgenetic/biparental mosaicism in an infant with hepatic mesenchymal hamartoma and placental mesenchymal dysplasia. Pediatr Dev Pathol 11, 377-383.

REIK, W., WALTER, J. (2001). Genomic imprinting: parental influence on the genome. Nat Rev Genet 2, 21-32.

ROBINSON, W.P., LAUZON, J.L., INNES, A.M., LIM, K., ARSOVSKA, S., MCFADDEN, D.E. (2007). Origin and outcome of pregnancies affected by androgenetic/biparental chimerism. Hum Reprod 22, 1114-1122. 
ROMANELLI, V., BELINCHON, A., BENITO-SANZ, S., MARTINEZ-GLEZ, V., GRACIA-BOUTHELIER, R., HEATH, K.E., CAMPOS-BARROS, A., GARCIAMINAUR, S., FERNANDEZ, L., MENESES, H., LOPEZ-SIGUERO, J.P., GUILLEN-NAVARRO, E., GOMEZ-PUERTAS, P., WESSELINK, J.J., MERCADO, G., ESTEBAN-MARFIL, V., PALOMO, R., MENA, R., SANCHEZ, A., DEL CAMPO, M., LAPUNZINA, P. (2010b). CDKN1C (p57(Kip2)) analysis in Beckwith-Wiedemann syndrome (BWS) patients: Genotype-phenotype correlations, novel mutations, and polymorphisms. Am J Med Genet A 152A, 1390-1397.

ROMANELLI, V., MENESES, H.N., FERNANDEZ, L., MARTINEZ-GLEZ, V., GRACIA-BOUTHELIER, R., M, F.F., GUILLEN, E., NEVADO, J., GEAN, E., MARTORELL, L., MARFIL, V.E., GARCIA-MINAUR, S., LAPUNZINA, P. (2011). Beckwith-Wiedemann syndrome and uniparental disomy 11p: fine mapping of the recombination breakpoints and evaluation of several techniques. Eur J Hum Genet 19, 416-421.

ROMANELLI, V., NEVADO, J., FRAGA, M., TRUJILLO, A.M., MORI, M.A., FERNANDEZ, L., PEREZ DE NANCLARES, G., MARTINEZ-GLEZ, V., PITA, G., MENESES, H., GRACIA, R., GARCIA-MINAUR, S., GARCIA DE MIGUEL, P., LECUMBERRI, B., RODRIGUEZ, J.I., GONZALEZ NEIRA, A., MONK, D., LAPUNZINA, P. (2010a). Constitutional mosaic genome-wide uniparental disomy due to diploidisation: an unusual cancer-predisposing mechanism. J Med Genet 48, 212-216.

ROSENBUSCH, B.E. (2010). The unresolved origin of uniparental diploid cell lines. Fertil Steril 93, e1; author reply e2.

RUSSO, S., FINELLI, P., RECALCATI, M.P., FERRAIUOLO, S., COGLIATI, F., DALLA BERNARDINA, B., TIBILETTI, M.G., AGOSTI, M., SALA, M., BONATI, M.T., LARIZZA, L. (2006). Molecular and genomic characterisation of cryptic chromosomal alterations leading to paternal duplication of the $11 \mathrm{p} 15.5$ Beckwith-Wiedemann region. J Med Genet 43, e39.

RUSSO, S., MENCARELLI, M., CAVALLERI, F., SELICORNI, A., COGLIATI, F., LARIZZA, L. (2003). A fluorescent method for detecting low-grade 11patUPD mosaicism in Beckwith-Wiedemann syndrome. Mol Cell Probes 17, 295-299.

SANDOVICI, I., KASSOVSKA-BRATINOVA, S., VAUGHAN, J.E., STEWART, R., LEPPERT, M., SAPIENZA, C. (2006). Human imprinted chromosomal regions are historical hot-spots of recombination. PLoS Genet 2, e101.

SASAKI, K., SOEJIMA, H., HIGASHIMOTO, K., YATSUKI, H., OHASHI, H., YAKABE, S., JOH, K., NIIKAWA, N., MUKAI, T. (2007). Japanese and North American/European patients with Beckwith-Wiedemann syndrome have different frequencies of some epigenetic and genetic alterations. Eur J Hum Genet 15, 1205-1210.

SCHONHERR, N., MEYER, E., ROOS, A., SCHMIDT, A., WOLLMANN, H.A., and EGGERMANN, T. (2007). The centromeric $11 \mathrm{p} 15$ imprinting centre is also involved in Silver-Russell syndrome. J Med Genet 44, 59-63. 
SCOTT, R.H., DOUGLAS, J., BASKCOMB, L., HUXTER, N., BARKER, K., HANKS, S., CRAFT, A., GERRARD, M., KOHLER, J.A., LEVITT, G.A., PICTON, S., PIZER, B., RONGHE, M.D., WILLIAMS, D., COOK, J.A., PUJOL, P., MAHER, E.R., BIRCH, J.M., STILLER, C.A., PRITCHARD-JONES, K., RAHMAN, N. (2008b). Constitutional 11p15 abnormalities, including heritable imprinting center mutations, cause nonsyndromic Wilms tumor. Nat Genet 40, 13291334.

SCOTT, R.H., DOUGLAS, J., BASKCOMB, L., NYGREN, A.O., BIRCH, J.M., COLE, T.R., CORMIER-DAIRE, V., EASTWOOD, D.M., GARCIA-MINAUR, S., LUPUNZINA, P., TATTON-BROWN, K., BLIEK, J., MAHER, E.R., RAHMAN, N. (2008). Methylation-specific multiplex ligation-dependent probe amplification (MS-MLPA) robustly detects and distinguishes 11p15 abnormalities associated with overgrowth and growth retardation. J Med Genet 45, 106-113.

SHARP, A., MOORE, G., EGGERMANN, T. (2001). Evidence from skewed X inactivation for trisomy mosaicism in Silver-Russell syndrome. Eur $\mathrm{J}$ Hum Genet 9, 887-891.

SHIELD, J.P., FLANAGAN, S.E., MACKAY, D.J., HARRIES, L.W., PROKS, P., GIRARD, C., ASHCROFT, F.M., TEMPLE, I.K., ELLARD, S. (2008). Mosaic paternal uniparental isodisomy and an ABCC8 gene mutation in a patient with permanent neonatal diabetes and hemihypertrophy. Diabetes 57, 255-258.

SHINDE, D., LAI, Y., SUN, F., and ARNHEIM, N. (2003). Taq DNA polymerase slippage mutation rates measured by $\mathrm{PCR}$ and quasi-likelihood analysis: (CA/GT)n and (A/T)n microsatellites. Nucleic Acids Res 31, 974-980.

SHUMAN, C., SMITH, A.C., STEELE, L., RAY, P.N., CLERICUZIO, C., ZACKAI, E., PARISI, M.A., MEADOWS, A.T., KELLY, T., TICHAUER, D., SQUIRE, J.A., SADOWSKI, P., WEKSBERG, R. (2006). Constitutional UPD for chromosome $11 \mathrm{p} 15$ in individuals with isolated hemihyperplasia is associated with high tumor risk and occurs following assisted reproductive technologies. Am J Med Genet A 140, 1497-1503.

SIEGEL, D.H., SLAVOTINEK, A. (2005). Uniparental disomy. Pediatr Dermatol 22, 482-487.

SLATTER, R.E., ELLIOTT, M., WELHAM, K., CARRERA, M., SCHOFIELD, P.N., BARTON, D.E., MAHER, E.R. (1994). Mosaic uniparental disomy in BeckwithWiedemann syndrome. J Med Genet 31, 749-753.

SMITH, A.C., SHUMAN, C., CHITAYAT, D., STEELE, L., RAY, P.N., BOURGEOIS, J., WEKSBERG, R. (2007). Severe presentation of Beckwith-Wiedemann syndrome associated with high levels of constitutional paternal uniparental disomy for chromosome 11p15. Am J Med Genet A 143A, 3010-3015.

SOARES, M.R., HUBER, J., RIOS, A.F., RAMOS, E.S. (2010). Investigation of IGF2/Apal and H19/Rsal polymorphisms in patients with cutaneous melanoma. Growth Horm IGF Res 20, 295-297. 
SPARAGO, A., CERRATO, F., VERNUCCI, M., FERRERO, G.B., SILENGO, M.C., RICCIO, A. (2004). Microdeletions in the human H19 DMR result in loss of IGF2 imprinting and Beckwith-Wiedemann syndrome. Nat Genet 36, 958-960.

SPENCE, J.E., PERCIACCANTE, R.G., GREIG, G.M., WILLARD, H.F., LEDBETTER, D.H., HEJTMANCIK, J.F., POLLACK, M.S., O'BRIEN, W.E., BEAUDET, A.L. (1988). Uniparental disomy as a mechanism for human genetic disease. Am J Hum Genet 42, 217-226.

SURANI, M.A., BARTON, S.C., NORRIS, M.L. (1984). Development of reconstituted mouse eggs suggests imprinting of the genome during gametogenesis. Nature $308,548-550$.

SURTI, U., HILL, L.M., DUNN, J., PROSEN, T., HOFFNER, L. (2005). Twin pregnancy with a chimeric androgenetic and biparental placenta in one twin displaying placental mesenchymal dysplasia phenotype. Prenat Diagn 25, 1048-1056.

TADOKORO, K., FUJII, H., INOUE, T., YAMADA, M. (1991). Polymerase chain reaction (PCR) for detection of Apal polymorphism at the insulin like growth factor II gene (IGF2). Nucleic Acids Res 19, 6967.

TAN, T.Y., AMOR, D.J. (2006). Tumour surveillance in Beckwith-Wiedemann syndrome and hemihyperplasia: a critical review of the evidence and suggested guidelines for local practice. J Paediatr Child Health 42, 486-490.

TUNA, M., KNUUTILA, S., MILLS, G.B. (2009). Uniparental disomy in cancer. Trends Mol Med 15, 120-128.

TURNER, C.L., MACKAY, D.M., CALLAWAY, J.L., DOCHERTY, L.E., POOLE, R.L., BULLMAN, H., LEVER, M., CASTLE, B.M., KIVUVA, E.C., TURNPENNY, P.D., MEHTA, S.G., MANSOUR, S., WAKELING, E.L., MATHEW, V., MADDEN, J., DAVIES, J.H., TEMPLE, I.K. (2010). Methylation analysis of 79 patients with growth restriction reveals novel patterns of methylation change at imprinted loci. Eur J Hum Genet 18, 648-655.

WAKELING, E.L., AMERO, S.A., ALDERS, M., BLIEK, J., FORSYTHE, E., KUMAR, S., LIM, D.H., MACDONALD, F., MACKAY, D.J., MAHER, E.R., MOORE, G.E., POOLE, R.L., PRICE, S.M., TANGERAAS, T., TURNER, C.L., VAN HAELST, M.M., WILLOUGHBY, C., TEMPLE, I.K., COBBEN, J.M. (2010). Epigenotype-phenotype correlations in Silver-Russell syndrome. J Med Genet 47, 760-768.

WEKSBERG, R., NISHIKAWA, J., CALUSERIU, O., FEI, Y.L., SHUMAN, C., WEI, C., STEELE, L., CAMERON, J., SMITH, A., AMBUS, I., LI, M., RAY, P.N., SADOWSKI, P., SQUIRE, J. (2001). Tumor development in the BeckwithWiedemann syndrome is associated with a variety of constitutional molecular $11 \mathrm{p} 15$ alterations including imprinting defects of KCNQ1OT1. Hum Mol Genet 10, 2989-3000.

WEKSBERG, R., SHUMAN, C., BECKWITH, J.B. (2010). Beckwith-Wiedemann syndrome. Eur J Hum Genet 18, 8-14. 
WILSON, M., PETERS, G., BENNETTS, B., MCGILLIVRAY, G., WU, Z.H., POON, C., ALGAR, E. (2008). The clinical phenotype of mosaicism for genome-wide paternal uniparental disomy: two new reports. Am J Med Genet A 146A, 137148.

YAMAZAWA, K., NAKABAYASHI, K., KAGAMI, M., SATO, T., SAITOH, S., HORIKAWA, R., HIZUKA, N., OGATA, T. (2010b). Parthenogenetic chimaerism/mosaicism with a Silver-Russell syndrome-like phenotype. J Med Genet 47, 782-785.

YAMAZAWA, K., NAKABAYASHI, K., MATSUOKA, K., MASUBARA, K., HATA, K., HORIKAWA, R., OGATA, T. (2011). Androgenetic/biparental mosaicism in a girl with Beckwith-Wiedemann syndrome-like and upd(14)pat-like phenotypes. J Hum Genet 56, 91-93.

YAMAZAWA, K., OGATA, T., FERGUSON-SMITH, A.C. (2010a). Uniparental disomy and human disease: an overview. Am J Med Genet C Semin Med Genet 154C, 329-334.

YOUSSOUFIAN, H., PYERITZ, R.E. (2002). Mechanisms and consequences of somatic mosaicism in humans. Nat Rev Genet 3, 748-758.

YUEN, R.K., JIANG, R., PENAHERRERA, M.S., MCFADDEN, D.E., ROBINSON, W.P. (2011). Genome-wide mapping of imprinted differentially methylated regions by DNA methylation profiling of human placentas from triploidies. Epigenetics Chromatin 4, 10.

ZANKL, A., ADDOR, M.C., GAIDE, A.C., THONNEY, F., COUSIN, P., SCHORDERET, D.F., GUDINCHET, F., NENADOV-BECK, M. (2000). Complex chromosome rearrangement in a girl with an incomplete form of Beckwith-Wiedemann syndrome. Am J Med Genet 95, 510-512. 


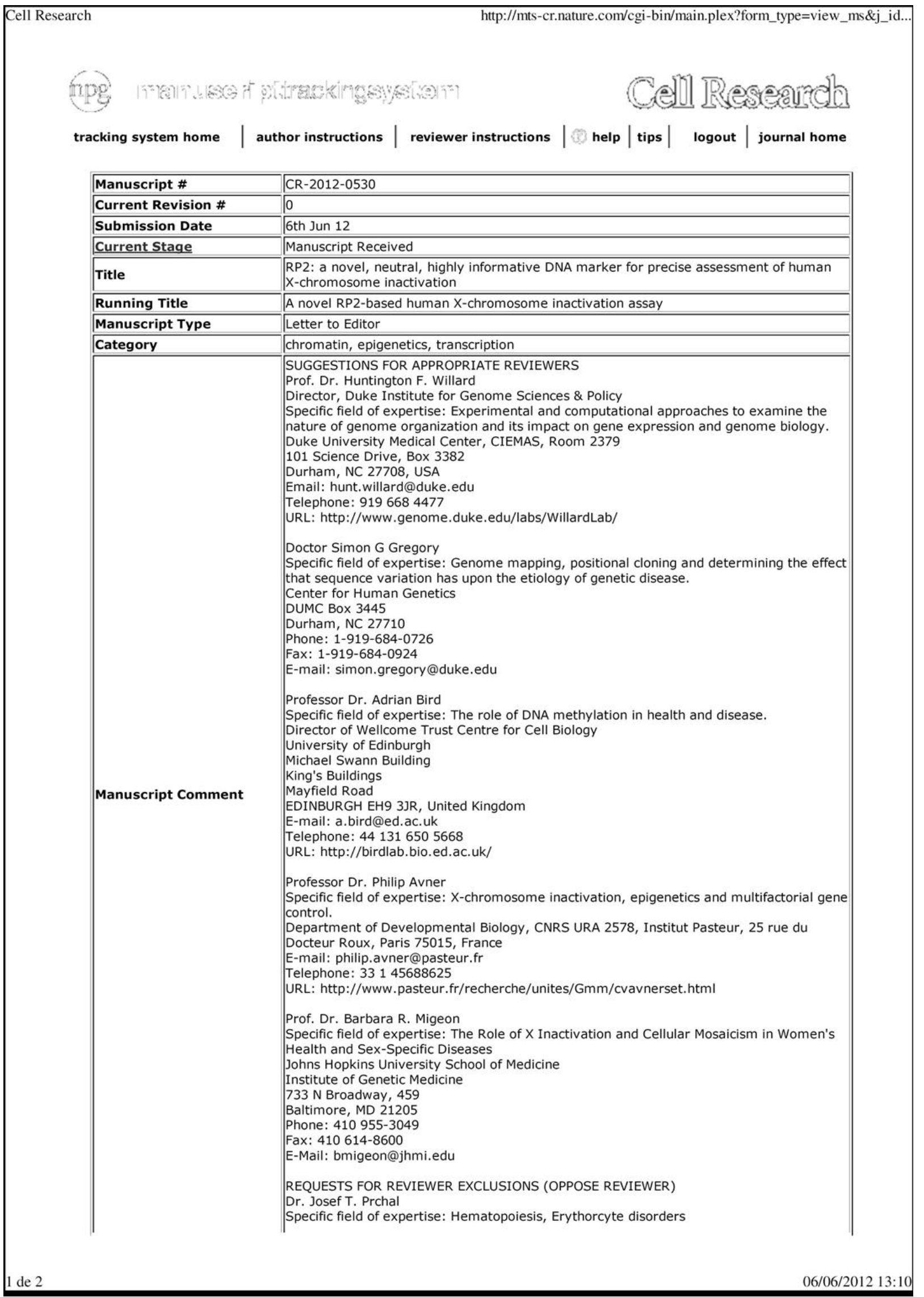


Cell Research

\begin{tabular}{|l|l|} 
& University of Utah, School of Medicine, Hematology Division, SOM 5C210, 30 N 1900 E, \\
Salt Lake City, UT 84132. \\
E-mail: josef.prchal@hsc.utah.edu \\
URL: http://medicine.utah.edu/internalmedicine/Hematology/physicians/prchal.htm \\
\\
$\begin{array}{l}\text { Dr. Lambert Busque } \\
\text { Specific field of expertise: chromosome X-inactivation in hematopoiesis, physiology of } \\
\text { aging hematopoiesis, pathogenesis of age-related hematopoietic malignancies and } \\
\text { clonality of cancers. } \\
\text { Hospital Maisonneuve-Rosemont, 5415, Boulevard de I'Assomption, Montréal, QC, } \\
\text { Canada H1T 2M4. } \\
\text { Telephone: } 5142523400 \text { ext. 4658 } \\
\text { E-mail: Ibusque.hmr@ssss.gouv.qc.ca } \\
\text { URL: http://www.sct-hmr.org/en/lbusque.php }\end{array}$ \\
\hline Corresponding Author & Prof. Enrique Medina-Acosta (Universidade Estadual do Norte Fluminense Darcy Ribeiro) \\
\hline \hline Contributing Authors & $\begin{array}{l}\text { Mr. Filipe Machado, Dr. Claudia Radic, Prof. Carlos De Brasi, Dr. Álvaro Lopes Rios, Dr. } \\
\text { Susana Chuva de Sousa Lopes, Dr. Ester Ramos }\end{array}$ \\
\hline Abstract & Not applicable (LETTER TO THE EDITOR) \\
\hline Editor & HUMARA, methylation, RP2, XCI, X-STRs \\
\hline Keywords & There is no duality of interest \\
\hline Duality of Interest &
\end{tabular}

\section{Manuscript Items}

1. Author Cover Letter PDF (195KB) Source File (DOC) $874 \mathrm{~KB}$

2. Merged File containing manuscript text and 1 Figure file. PDF (5129KB)

a. Article File PDF (159KB) Source File (DOC) 150KB

b. Figure - Multi-part A-E PDF (4974KB) Source File (JPG) 4056KB

3. Supplementary information, Material and Methods PDF (56KB) Source File (PDF) $161 \mathrm{~KB}$

4. Supplementary information, Figure S1 PDF (34KB) Source File (PDF) 118KB

5. Supplementary information, Figure S2 PDF (48KB) Source File (PDF) 232KB

6. Supplementary information, Figure S3 PDF (37KB) Source File (PDF) 94KB

7. Supplementary information, Figure S4 PDF (47KB) Source File (PDF) $125 \mathrm{~KB}$

8. Supplementary information, Figure S5 PDF (33KB) Source File (PDF) 120KB

9. Supplementary information, Table S1 PDF (35KB) Source File (PDF) 158KB

10. Supplementary information, Table S2 PDF (33KB) Source File (PDF) 87KB

11. Supplementary information, Table S3 PDF (36KB) Source File (PDF) $121 \mathrm{~KB}$

12. Supplementary information, Table S4 PDF (38KB) Source File (PDF) 122KB

13. Supplementary information, Table S5 PDF (32KB) Source File (PDF) 102KB

\section{More Manuscript Info and Tools}

Send Manuscript Correspondence

Check Status

\section{leJournalPress}

tracking system home | author instructions | reviewer instructions | help | tips | logout | journal home | terms of use 
Title of manuscript:

Authors:

Submit to:

I assure that this manuscript has not been and will not be considered for print or electronic publication elsewhere other than as an abstract in any languages.

And all the authors agreed to submit this manuscript to Cell Research.

Signed by correspondence:

Date:

Affiliation:

Editorial Office of Cell Research, Institute of Biochemistry and Cell Biology, Shanghai Institutes for Biological Sciences, Chinese Academy of Sciences, 319 Yueyang Road, Shanghai 200031

Tel: 0086-21-54920953; Fax: 0086-21-54920952; E-mail: cellres@sibs.ac.cn

Cell Research | www.cell-research.com 


\title{
Haemophilia
}

Haemophilia (2012), 1-2

DOI: $10.1111 / \mathrm{j} .1365-2516.2012 .02859 . \mathrm{x}$

LETTER TO THE EDITOR

\section{Accurate tracking genetic markers in haemophilia linkage analysis: a matter beyond scientific priority}

\author{
F. B. MACHADO* and E. MEDINA-ACOSTA ${ }^{*}$ \\ - Departamento de Genética, Faculdade de Medicina de Ribeirão Preto, Universidade de São Paulo, Ribeirão Preto, São Paulo; †Laboratório de \\ Biotecnologia, Centro e Biociências e Biotecnologia, Universidade Estadual do Norte Fluminense Darcy Ribeiro, Campos do Goytacazes, Rio de Janeiro; \\ and $¥$ Hospital Escola Álvaro Alvim, Campos dos Goytacazes, Rio de Janeiro Brazil
}

\begin{abstract}
Accuracy of polymorphic genetic markers is a quality requirement for trustfulness and reliability of linkage analyses aimed at tracking defective $F 8$ genes in at-risk haemophilia A families. Accurate registry of makers' names is a quality requirement of scientific priority claims. In this regard, it struck us with surprise the recent publication in this journal by Ding et al. [1], who claimed credit for novelty in the identification of tree short tandem repeats (STR, microsatellite) loci (coined names F8Up226, F8Up146 and F8Down 48 [1]), Table 1. We would like to bring attention of readers to relevant prior reports authored by us in this journal, which seemingly passed unnoticed to Dign et al. Firstly, we specifically referred to these three loci using a scientific priority-based nomenclature in our 2009 publication concerning a high-resolution combined linkage physical map of short tandem repeat loci on human chromosome band Xq28 for indirect haemophilia A carrier detection [2], Table 1. That information has been also online since 2008, and available through the NCBI $F \&$ gene site from the HEMApSTR web (The Haemophilia A extragenic and intragenic factor VIII (FVIII) Short Tandem Repeats Map Inventory Database) [3]. Secondly, Dign et al. asserted to have genotyped the F8Int 25 locus, but did not specify which microsatellite locus, also failing to cite a reference source. From the STR map inventory database, typing laboratories became aware that within intron 25 there are three microsatellite loci:
\end{abstract}

F8int25.1, F8Int25.2 and F8Int25.3 (reviewed by us in references [2-4]). PCR in silico validation of the primers used by Dign et al. unveils that they genotyped the F8Int25.2 repeat locus. The F8Int25.2 locus was earlier described by us, and tried-and-tested as highly informative $[4,5]$. Thirdly, for the F8Int25.2, F8Up146 and F8Up226 loci, Dign et al. reported amplicon sizes that are above expectation (Table 1), and therefore discordant with the number of repeats reported by them for each observed allele. Let us take for instance the $F 8$ int 25.2 allele with 19 repeat units for the reference assembly GRCh $37 / \mathrm{hg} 19$ of the human X chromosome sequence. Considering the physical coordinates for the primers used by Ding et al., the amplicon should be 191 bp in length, however, Ding et al. reported amplicons ranging 331-359 bp (Table 1). Fourthly, Dign et al. asserted that their 'novel' panel of six STR loci had more advantages than those reported previously, but failed to confront it with available evidence for an improved criterion-referenced assessment in indirect tracking of haemophilia A using the 0.23 cM-resowrion dense polymorphic journal [6]. Finally, we had earlier provisioned a scientific priority journal [6]. Finally, we had earlier provisioned a scientific priority-
based suggestion for naming new tried-and-tested polymorphic loci used in linkage analysis in haemophilia A $[2,3]$ with the intended purpose of facilitating accurately tracking markers and, thus, curtailing unsuitable scientific priority claims.

Table 1. Marker loci studied by Dign et al. [1] that were specifically referred to in the high-resolution combined linkage physical map of STR loci reported earlier by Machado and Medina-Acosta [2,3].

\begin{tabular}{|c|c|c|c|c|c|c|}
\hline Locus name & Forward primer & Reverse primer & In silico" & Repeats $^{\dagger}$ & Range $^{\ddagger}$ & Position $(\mathrm{Mb})^{5}$ \\
\hline MPP1Int5 [2,3] & ggatctgggtcgtctgtctc & gagttgggaagtgccatcat & 281 & 23 & & $154015245 . .154015525$ \\
\hline F8Down 48 [1] & gtttgggaagtgccatcattttc & tggatctgggtcgtctgtct & 281 & 23 & $275-307$ & $154015244 . .154015524$ \\
\hline$F 8 \operatorname{Int} 25.2[2-4]$ & ctctaggetgccaactcacc & tcatggttcccaaagaaaca & 144 & 14.5 & & $154082796 . .154082939$ \\
\hline F8Int25 [1] & caaagaaacaaaaccagaaccaa & gttgggtctgtagcetgctggtc & 191 & 14.5 & $331-359$ & $154082739 . .154082929$ \\
\hline StSG604486 [2,3] & tggcaatttcagatcacttcttt & ggttttctttgtggecaagt & 216 & 26.5 & & $154397628 . .154397843$ \\
\hline F8Up146 [1] & tttgttacggttttcttgtgg & gtttcttggcaatttcagatcacttcttt & 230 & 26.5 & $423-455$ & $154397622 . .154397851$ \\
\hline HEMA154130.5 [2,3] & atgatgtacaagccctacctga & tgagccagggaagaatgaaa & 162 & 19 & & $154477291 . .154477452$ \\
\hline F8Up226 [1] & agaacagcaaaggaactggtg & teccacaccectetctaaat & 153 & 19 & $222-258$ & $154477319 . .154477471$ \\
\hline
\end{tabular}

"PCR in silico amplicon size in base pairs using the reported primers, as determined for reference assembly sequence GRCh37/hg19 of the human genome (http://genome.ucsc.edu/) [7].

Number of repeat units determined in genome reference sequence assembly Feb.2009 (GRCh37/hg19) using Tandem Repeat Finder software (http:// tandem.bu.edu/trf/trf.html) [8].

Ebserved amplicon range in base pairs as reported in [1], discordant with the in silico amplicon size for GRCh37/hg19.

${ }^{5}$ Distance in base pairs from Xp-tel, as determined using GRCh37/hg19. The F8 gene maps on the physical interval chrX:154064063-154250998 (http:// genome.ucsc.edu/).

Correspondence: E. Medina-Acosta, Laboratory of Biotechnology, Center for Biosciences and Biotechnology, Universidade Estadual do Norte Fluminense Darcy Ribeiro, Avenida Alberto Lamego 2000, Parque Califórminense Darcy Ribeiro, Avenida Alberto Lamego 2000,
nia, Campos dos Goytacazes, RJ, CEP 28013-602, Brazil. nia, Campos dos Goytacazes, RJ, CEP 28013-602,
Tel: +55222726 6758; fax: +55 2227397031 ; e-mail: quique@uenf.br

Accepted after revision 25 April 2012

\section{Acknowledgements}

EMA-A and FBM wrote the Letter. EM-A is a National Research Council (CNPq) fellow, and his research is supported by Grants from $\mathrm{CNPq}$ and Fundação Carlos Chagas Filho de Amparo à Pesquisa do Estado do Rio de Janeiro - FAPERJ, Brazil. FBM is a Graduate Fellow from Fundação de Janeiro - FAPERJ, Brazil. FBM is a Graduate Fellow
de Amparo à Pesquisa do Estado de São Paulo - FAPESP. 


\section{LETTER TO THE EDITOR}

\section{Disclosures}

The authors have no relevant affiliations or financial involvement with any organization or entity with a financial interest in or financial conflict with the subject matter or materials discussed in this review. This includes employment, consultancies, honoraria, stock ownership or options, expert testimony, grants or patents received or pending, or royalties. No writing assistance was utilized in the production of this manuscript.

\section{References}

1 Ding QL, Lu YL, Dai J, Xi XD, Wan XF, Wang HL. Characterisation and validation of a novel panel of the six short tandem repeats for genetic counselling in Chinese repeats for genetic counselling in Chinese haemophilia A pedigrees. Haemophilia 2012, Jan 26. doi: 10.1111/j.1365-2
02732.x. (Epub ahead of print).

02732.x. (Epub ahead of print).
2 Machado FB, Medina-Acosta E. High-resoMachado $\mathrm{FB}$, Medina-Acosta combined linkage physical map of short tandem repeat loci on human chromosome band Xq28 for indirect haemophilia A carrier detection. Haemophilia 2009; 15 297-308.

3 Medina-Acosta F, Machado FB, 2008 HEMAPSTR - Onlinel Available at hetp.// Www. pSTR.html. Accessed April 7, 2012.

4 Machado FB, Duarte LP, Medina-Acosta E. A novel informative dinucleotide microsatelA novel informative dinucleotide microsatellite marker located on human factor VII
intron 25. Haemophilia 2009; 15: 613-4.

Medina-Acosta E. Interlocus non-rando association of multiallelic polymorphisms spanning the coagulation factor VIII gene on human chromosome distalmost Xq28. Hae mophilia 2010; 16: 525-37.

6 Machado FB, Duarte LP, Medina-Acosta E. Improved criterion-referenced assess indirect tracking of haemophisssment in indirect $0.23 \mathrm{cM}$-resolution dense polymorphic mar7 Fujita PA, Rhead B, Zweig AS et al. The UCSC Genome Browser database: Updat 2011. Nucleic Acids Res 2011; 39: D876-82. 8 Benson G. Tandem repeats finder: A program to analyze DNA sequences. Nucleic Acids Res 1999; 27: 573-80. 


\title{
Gametic phase disequilibrium between the syntenic multiallelic HTG4 and HMS3 markers widely used for parentage testing in Thoroughbred horses
}

\author{
Filipe Brum Machado • Luana de Vasconcellos Machado \\ Cynthia Rachid Bydlowski · Sergio Paulo Bydlowski ·
} Enrique Medina-Acosta

\begin{abstract}
Validation of parentage and horse breed registries through DNA typing relies on estimates of random match probabilities with DNA profiles generated from multiple polymorphic loci. Of the twenty-seven microsatellite loci recommended by the International Society for Animal Genetics for parentage testing in Thoroughbred horses, eleven are located on five chromosomes. An important aspect in determining combined exclusion probabilities is the ascertainment of the genetic linkage status of syntenic markers, which may affect reliable use of
\end{abstract}

Electronic supplementary material The online version of this article (doi:10.1007/s11033-011-0881-4) contains supplementary material, which is available to authorized users.

F. B. Machado

Departamento de Genética, Faculdade de Medicina de Ribeirão Preto, Universidade de São Paulo, Avenida Bandeirantes, 3900 Monte Alegre, Ribeirão Preto, SP CEP 14049-900, Brazil

L. de Vasconcellos Machado · E. Medina-Acosta Núcleo de Diagnóstico e Investigação Molecular, Hospital Escola Álvaro Alvim, Rua da Lagoa Dourada 409, Pelinca, Campos dos Goytacazes, RJ CEP 28035-010, Brazil

C. R. Bydlowski

LinkGen Biotecnologia Veterinária e Agropecuária, Rua Abílio Soares 233, Paraíso, São Paulo, SP CEP 04005-000, Brazil

S. P. Bydlowski

Laboratório de Genética e Hematologia Molecular, Faculdade de Medicina da Universidade de São Paulo, Avenida Dr Enéas de Carvalho Aguiar 155, São Paulo, SP CEP 05403-000, Brazil

E. Medina-Acosta $(\bowtie)$

Laboratório de Biotecnologia, Centro de Biociências e Biotecnologia, Universidade Estadual do Norte Fluminense Darcy Ribeiro, Avenida Alberto Lamego 2000, Parque Califórnia, Campos dos Goytacazes, RJ CEP 28013-602, Brazil e-mail: quique@uenf.br the product rule in estimating random match probabilities. In principle, linked markers can be in gametic phase disequilibrium (GD). We aimed at determining the extent, by frequency and strength, of GD between the HTG4 and HMS3 multiallelic loci, syntenic on chromosome 9. We typed the qualified offspring $\left(n_{1}=27 ; n_{2}=14\right)$ of two Quarter Bred stallions (registered by the Brazilian Association of Quarter Horse Breeders) and 121 unrelated horses from the same breed. In the 41 informative meioses analyzed, the frequency of recombination between the HTG4 and HMS3 loci was 0.27 . Consistent with genetic map distances, this recombination rate does not fit to the theoretical distribution for independently segregated markers. We estimated sign-based $D^{\prime}$ coefficients as a measure of GD, and showed that the HTG4 and HMS3 loci are in significant, yet partial and weak, disequilibrium, with two allele pairs involved (HTG4*M/HMS $3 * \mathrm{P}, D^{\prime}(+)=$ 0.6274 ; and $\left.\mathrm{HTG} 4 * \mathrm{~K} / \mathrm{HMS} 3 * \mathrm{P}, D^{\prime}(-)=-0.6096\right)$. These results warn against the inadequate inclusion of genetically linked markers in the calculation of combined power of discrimination for Thoroughbred parentage validation.

Keywords Equine $\cdot$ Linkage disequilibrium .

Microsatellite - Parentage validation · Product rule · STR

\section{Introduction}

The Equine Genetics and Thoroughbred Parentage Testing Standardization Committee of the International Society for Animal Genetics (ISAG) recommends the use of a panel of 12 autosomal dinucleotide microsatellites for validation of the kinship relation of an offspring to the parents [1]. The panel consists of HMS7, ASB17, ASB23, HMS6, AHT5, HMS3, HTG4, HMS2, ASB2, HTG10, AHT4, and VHL20 
markers. For kinship cases in which single allelic exclusions are observed, ISAG recommends further typing with the Microsatellite 15 TKY System [2], comprising the dinucleotide markers TKY297, TKY374, TKY337, TKY344, TKY312, TKY343, TKY279, TKY341, TKY287, TKY321, TKY301, TKY394, TKY294, TKY333, and TKY325. Typing DNA with either panel enables combined exclusion probabilities $>99.99 \%$, in compliance with the requirement $(>99.95 \%)$ made by the International Stud Book Committee for accurate registry of Thoroughbred worldwide. Eleven of these microsatellite markers are located on five chromosomes: HMS7, TKY29 and TKY374 map to Equus caballus chromosome 1 (ECA1); HMS6 and TKY337 map to ECA4; HMS3, and HTG4 map to ECA9; TKY279, and TKY341 map to ECA16; AHT4, and TKY394 map to ECA24 (Table 1). The sex-averaged genetic linkage distances estimated between the syntenic loci (i.e., located on the same chromosome whether or not there is demonstrable genetic linkage between them) range from 10 to $96 \mathrm{cM}$.

An important aspect in determining combined exclusion probabilities is the genetic linkage status of syntenic markers, which, in contrast to common believe, may affect reliable use of the product rule in estimating random match probabilities of DNA [3, 4]. The product rule is the most common method for computing the frequency of DNA profiles in forensic laboratories [5]. This method depends critically on the assumption that loci segregate independently.

Markers that are located on separate chromosomes are expected to segregate independently of one another during meiosis, which supports the use of the product rule [3]. However, syntenic markers may be, in principle, subjected to gametic phase disequilibrium (GD) [4]. GD is a multifactorial evolutionary dynamic phenomenon that occurs at normal selection, characterized by significant and intensityvariable nonrandom associations of alleles at different DNA loci [6].

Despite available data on the genetic distances between microsatellite loci in the equine genome (Table 1) [7], parentage testing laboratories continue to use tightly linked loci to estimate combined exclusion probabilities. They argue, at considerable risk of error, that linked loci may contribute to the power of exclusion and/or that it is almost certain that the remaining power of using 12 or 15 microsatellite markers will remain quite impressive to horse breeders [2, 8, 9].

In this study, we tested the HTG4 and HMS3 loci for independence of segregation, and measured GD by using signed-based $D^{\prime}$ coefficient, which is a widely used measure of the overall extent of GD [6]. $D^{\prime}$ gives quantities of the absolute value of the Lewontin normalized $D$ value, weighted by the frequencies of the gametes when there is no disequilibrium, and it has the same range of values (varying between -1 and +1 ) for all allelic frequencies [10]. In common with most other measures of GD, normalized $D$ expresses numerical disequilibrium as the difference between the observed frequency of a given twolocus haplotype and its expected frequency if the alleles were segregated at random [11, 12].

\section{Materials and methods}

Animal samples

Hair roots were drawn from the qualified offspring ( $n_{1}=27 ; n_{2}=14$ ) of two stallions registered by the Brazilian Association of Quarter Horse Breeders, and 121 unrelated horses from the same breed.

\section{DNA preparation}

Genomic DNA from 6-10 hair bulbs was prepared by protein digestion in $100 \mu \mathrm{l} 10 \mathrm{mM}$ Tris- $\mathrm{HCl}$ pH 8.0 containing $0.5 \%$ Tween- 20 and $20 \mathrm{mg} / \mathrm{ml}$ of Proteinase $\mathrm{K}$, at $60^{\circ} \mathrm{C}$ for $1 \mathrm{~h}$, followed by heat inactivation of the proteinase at $95^{\circ} \mathrm{C}$ for $10 \mathrm{~min}$, on a GeneAmp ${ }^{\circledR}$ PCR System 9700 (Applied Biosystems, Foster City, CA, USA).

\section{Microsatellite genotyping}

HTG4 and HMS3 loci were typed by quantitative fluorescent PCR from approximately 2 ng of target DNA, and using published primer sequences [13]. Quantitative fluorescent PCR was employed for typing animals with the HTG4 and HMS3 markers as this is the method used with the Microsatellite 15 TKY systems [2], StockMarks ${ }^{\circledR}$ for Horses Equine 17-plex Genotyping Kit (Applied Biosystems), and Equine Genotypes ${ }^{\mathrm{TM}}$ Panel 1.1 (Finnzymes Diagnostics, Espoo, Finland [8, 14]. The forward primers were modified at the $5^{\prime}$ end by the addition of the fluorescent dyes 6-FAM ${ }^{\mathrm{TM}}$ (HTG4) and TAMRA ${ }^{\mathrm{TM}}$ (HMS3). DNA typing was performed on the ABI 310 Prism Genetic Analyzer (Applied Biosystems). Amplification products were analyzed by GeneScan Analysis 3.7 Software (Applied Biosystems) and Genotyper 3.7 software (Applied Biosystems).

\section{In-silico PCR}

Confirmation of the physical map positions for the twentyseven microsatellites loci markers was by ePCR on the Equus caballus whole genome assembly EquCab2.0 sequence [15], available from the UCSC Genome 
Table 1 Chromosome location, physical position and sex-averaged genetic linkage maps distances for the microsatellite markers recommended by the International Society for Animal Genetics (ISAG) for parentage testing of Thoroughbred horses

\begin{tabular}{|c|c|c|c|c|c|c|c|}
\hline Locus & Chromosome & GenBank & Physical position $^{\mathrm{a}}$ & Genetic distance $^{\mathrm{b}}$ & Pattern $^{\mathrm{c}}$ & Copy number ${ }^{\mathrm{d}}$ & Gene \\
\hline TKY297 & ECA1 & CM000377 & $62748036-62748265$ & 69.3 & $\mathrm{AC}$ & 17.5 & None \\
\hline TKY374 & ECA1 & & $98084670-98084873$ & 104.3 & $\mathrm{CA}$ & 13.5 & None \\
\hline HMS7 & ECA1 & & $162381788-162381964$ & 156.5 & TG & 19.5 & LOC100050866 \\
\hline ASB17 & ECA2 & CM000378 & $30600996-30601100$ & $\mathrm{ND}^{\mathrm{e}}$ & $\mathrm{AC}$ & 20.0 & LOC100071487 \\
\hline ASB23 & ECA3 & CM000379 & 79279164-79279294 & 110.3 & TG & 18.0 & None \\
\hline HMS6 & $\mathrm{ECA} 4^{\mathrm{f}}$ & CM000380 & $7229263-7229423$ & 10.1 & $\mathrm{AC}$ & 15.0 & COG5 \\
\hline TKY337 & ECA4 & & 29877320-29877496 & ND & $\mathrm{AC}$ & 16.5 & None \\
\hline TKY344 & ECA5 & CM000381 & 92501338-92501445 & 44.3 & $\mathrm{AC}$ & 20.0 & None \\
\hline TKY312 & ECA6 & CM000382 & $17320138-17320239$ & 40.1 & $\mathrm{AC}$ & 14.5 & None \\
\hline AHT5 & ECA8 & CM000384 & chrUn:2240758-2240895 & 0.0 & $\mathrm{AC}$ & 20.0 & Unknown \\
\hline HTG4 & ECA9 & CM000385 & $1497811-1497937$ & 0.0 & $\mathrm{CA}$ & 14.0 & None \\
\hline HMS3 & ECA9 & & $16895898-16896054$ & 29.5 & TG & 20.0 & LOC100062961 \\
\hline HMS2 & ECA10 & CM000386 & $52713432-52713653$ & ND & $\mathrm{CA}$ & 15.0 & GRIK2 \\
\hline TKY343 & ECA11 & CM000387 & $12997527-12997683$ & 25.6 & $\mathrm{AC}$ & 19.5 & CCDC46 \\
\hline ASB2 & ECA15 & CM000391 & $54612610-54612855$ & 51.0 & $\mathrm{AC}$ & 22.0 & None \\
\hline TKY279 & ECA16 & CM000392 & $6632322-6632454$ & ND & CA & 21.0 & PMCA \\
\hline TKY341 & ECA16 & & $81718690-81718837$ & ND & $\mathrm{AC}$ & 15.0 & None \\
\hline \multirow[t]{2}{*}{ TKY287 } & ECA17 & CM000393 & $4470482-4470721$ & 2.6 & $\mathrm{AC}$ & 17.0 & MIPEP \\
\hline & & & & & $\mathrm{AC}$ & 16.5 & \\
\hline TKY321 & ECA20 & CM000396 & $61778031-61778228$ & $\mathrm{ND}^{\mathrm{e}}$ & $\mathrm{AC}$ & 19.5 & LOC100070855 \\
\hline HTG10 & ECA21 & CM000397 & $17139092-17139188$ & 24.5 & TG & 19.0 & None \\
\hline TKY301 & ECA23 & CM000399 & $21066857-21067013$ & 25.7 & $\mathrm{AC}$ & 18.5 & None \\
\hline AHT4 & ECA24 & CM000400 & 23415673-23415826 & ND & $\mathrm{AC}$ & 28.5 & None \\
\hline TKY394 & ECA24 & & $33978834-33979081$ & 23.9 & $\mathrm{AC}$ & 19.5 & TTC7B \\
\hline TKY294 & ECA27 & CM000403 & 19565161-19565382 & 29.6 & $\mathrm{AC}$ & 21.0 & None \\
\hline TKY333 & ECA28 & CM000404 & 2475734-2475846 & 0.0 & $\mathrm{CA}$ & 22.0 & None \\
\hline TKY325 & ECA29 & CM000405 & $27565084-27565283$ & 48.3 & $\mathrm{AC}$ & 27.0 & None \\
\hline VHL20 & ECA30 & CM000406 & $18793901-18793987$ & 31.4 & TG & 13.0 & None \\
\hline
\end{tabular}

${ }^{a}$ Distance in base pairs from chromosome p-tel, as determined using the chromosome reference sequences. Indicated is the interval between the $5^{\prime}$ nucleotide in forward and reverse primers that define each locus (see Online Resource ESM_1 for details)

${ }^{\mathrm{b}}$ Sex-averaged genetic linkage map position in centimorgans (cM), as reported by Swinburne et al. (2006) [7]

${ }^{c}$ Consensus (upper strand) sequence pattern of the repeat element determined using the Tandem Repeat Finder (TRF) program [28]

${ }^{\mathrm{d}}$ Repeat copy number determined using TRF

${ }^{\mathrm{e}}$ Not determined [7]. Although estimates have been reported using chromosome-specific centimorgan to megabase (cM/Mb) linear conversion ratios [23], they are based on the assumption that recombination is a monotonic function of physical length (i.e., meaning that rates are equally distributed along the chromosome). Contrasting, recombination rates vary extensively along human chromosomes [29]

${ }^{\mathrm{f}}$ Syntenic loci (i.e., located on the same chromosome whether or not there is demonstrable linkage between them) are shaded grey

${ }^{g}$ We failed to locate marker AHT5 on chromosome 8 reference sequence NC_009151 (release July 14 2008). The primer sequences for this marker are the same reported for UniSTS:504179 AHT005 that defines an unmapped marker on contig Chr Un NW 001875797, (chrUn:2240758.0.2240895), which yields a 138 bp e-PCR product, with a consensus AC repeat (see Online Resource ESM_1 for details). By FISH, AHT005 was reported to be located near ECA8 p-tel, tightly linked to UniSTS:504185 COR097 (physical position 1441839-1442082 bp; genetic distance $0.0 \mathrm{cM}$ ) on the genetic linkage map [7]

Bioinformatics browser [16], and using published primer sequences (Online Resource 1). Gene locations were verified at the MapViewer browser, available from the National Center for Biotechnology Information [17]. Sex-averaged genetic linkage distances are from the single linkage group per chromosome genetic map for the horse [7].
Analysis of data

Allele frequencies, observed heterozygosity $\left(H_{\mathrm{o}}\right)$, expected heterozygosity $\left(H_{\mathrm{e}}\right)$, forensic parameters [matching probability, MP; power of discrimination, PD; polymorphism information content, PIC; paternity parameters (power of 
exclusion, PE; typical paternity index, TPI)] were computed using the PowerStatV12 ${ }^{\circledR}$ (Promega Corporation. Madison, USA) and DNAView ${ }^{\circledR}$ (DNAView.com, Oakland, USA) software. Divergence from Hardy-Weinberg Equilibrium (HEW; exact test based on 30,000 Monte Carlo trials), and $F_{\text {IS }}$ inbreeding coefficients (i.e., the probability of homozygosity by descent) were estimated using the stand-alone Genetic Data Analysis (GDA) software [18].

Estimation of overall and multiallelic interallelic GD

Significance of overall GD was estimated using the Fisher exact test of independence for 30,000 runs using the GDA software [18]. The frequency and intensity of interallelic disequilibria involving the HTG4/HMS3 two-locus combination were determined using the stand-alone Multiallelic Interallelic Disequilibrium Analysis Software (MIDAS) [19]. We restricted the analysis to significant values of the $D^{\prime}$ coefficient [6]. We carried out the interallelic analysis taking into account the positive $\left(D^{\prime}>0\right)$ and negative $\left(D^{\prime}<0\right)$ signs of the observed disequilibria. The $D^{\prime}(+)$ sign indicates that the two-locus haplotype frequency is significantly higher than expected, whereas the $D^{\prime}(-)$ sign indicates that the two-locus haplotype frequency is significantly lower than expected [10]. The strength of sign-based overall disequilibrium for the two-locus combination was determined using the formulas worked out by Zapata et al. (2001) [20]. We estimated significance of positive and negative interallelic disequilibria using the Yates' correction for continuity (Yates' chisquare test) from the MIDAS program.

\section{Results}

We first revised the physical location of the twenty-seven microsatellite loci recommended by the ISAG for parentage testing and verification of Thoroughbred horses (Table 1). We based our analysis on the most recent release
Table 2 Allele frequency distribution, forensic parameters and significance of sign-based gametic phase disequilibrium for the HTG4 and HMS3 microsatellite locus-pair from 121 unrelated Quarter Bred horses

\begin{tabular}{|c|c|c|}
\hline Allele & HTG4 & HMS3 \\
\hline $\mathrm{H}$ & & 0.0125 \\
\hline I & & 0.2000 \\
\hline K & 0.2562 & \\
\hline $\mathrm{L}$ & 0.0620 & \\
\hline M & 0.5785 & 0.3375 \\
\hline $\mathrm{N}$ & 0.0372 & 0.1375 \\
\hline $\mathrm{O}$ & 0.0248 & 0.0208 \\
\hline$P$ & 0.0413 & 0.2458 \\
\hline $\mathrm{R}$ & & 0.0458 \\
\hline$n$ & 242 & 242 \\
\hline Matching probability (MP) & 0.2229 & 0.0997 \\
\hline Power of discrimination (PD) & 0.7771 & 0.9003 \\
\hline Polymorphism information content (PIC) & 0.5421 & 0.7270 \\
\hline Power of exclusion (PE) & 0.3154 & 0.4956 \\
\hline Typical paternity index (TPI) & 1.3152 & 1.9355 \\
\hline Homozygotes & 0.3802 & 0.2583 \\
\hline Heterozygotes & 0.6198 & 0.7417 \\
\hline Expected heterozygosity $\left(H_{\mathrm{E}}\right)$ & 0.5946 & 0.7691 \\
\hline Hardy-Weinberg equilibrium (HWE) & 0.8132 & 0.0780 \\
\hline Fis & -0.0426 & 0.0330 \\
\hline \multicolumn{3}{|l|}{ Gametic phase disequilibrium } \\
\hline Fisher exact test $P$ value & 0.0267 & \\
\hline Allele pairs involved & $\begin{array}{l}\mathrm{HTG} 4 * \mathrm{M} / \mathrm{HMS}{ }^{*} \mathrm{P} \\
\mathrm{HTG} 4 * \mathrm{~K} / \mathrm{HMS} 3 * \mathrm{P}\end{array}$ & \\
\hline$D^{\prime}(+)$ & 0.6274 & \\
\hline$D^{\prime}(-)$ & -0.6097 & \\
\hline Yates $\chi^{2} D^{\prime}(+)$ & 10.0433 & \\
\hline Yates $\chi^{2} D^{\prime}(-)$ & 4.0755 & \\
\hline
\end{tabular}


of the reference genome of the Equus caballus and published primer sequences. Few nucleotide differences with the reference sequence were noted for some primers (Online Resource 1).

The physical distance between the HTG4 and HMS3 loci is $15,398,087 \mathrm{bp}$. Based on the single linkage group per chromosome genetic map available for the horse [7], the sex-averaged genetic linkage distance between the said markers is $29.5 \mathrm{cM}$ (i.e., rate of recombination of 0.29). This genetic length, therefore, implies that in $70.5 \%$ of all meioses, HTG4 and HMS3 alleles are transferred in block (i.e., they do not segregate independently) to offspring.

We confirmed the genetic linkage status of the HTG4 and HMS3 loci by genotyping the qualified offspring $\left(n_{1}=27 ; n_{2}=14\right)$ of two Quarter Horse Stallions. In the 41 informative meioses analyzed, the frequency of recombination between the HTG4 and HMS3 loci was 0.27 , consistent with known genetic map distance of $29.5 \mathrm{cM}$ [7]. This recombination rate does not fit to the theoretical distribution for independently segregated markers $\left(\chi^{2}=8.8 ; P=0.003012\right)$.

To ascertain the level of significance and the pattern, by frequency and strength, of non-random multiallelic interallelic associations, we typed 121 unrelated Quarter Bred horses. We determined sign-based $D^{\prime}$ coefficients as a variable measure of GD. The Fisher test of independence indicated that HTG4 and HMS3 loci were in linkage disequilibrium ( $P=0.0267 ; 30,000$ permutations, Table 2$)$. Two allele pairs exhibited significant GD: HTG4*M/ HMS3 $* \mathrm{P} \quad\left(D^{\prime}(+)=0.6274\right)$ and $\mathrm{HTG} 4 * \mathrm{~K} / \mathrm{HMS} 3 * \mathrm{P}$ $\left(D^{\prime}(-)=-0.6096\right)$, Table 2 . These allele pair associations were maintained over statistically non-significant interallelic associations (i.e., background GD) between the HTG4 and HMS3 multiallelic markers (Online Resource 2).

\section{Discussion}

Meaningful calculation of combined power of discrimination requires accurate knowledge about genetic linkage status of markers. The inappropriateness of the product rule for syntenic loci is not a new issue, and it was recently discussed in the field of human forensic genetics [4]. Many forensic researches working with linked markers fail to curtail misuse of the product rule. By dismissing GD, typing laboratories erroneously claim that their marker sets offer comparable, if not greater, discriminatory power than typing with an equal number of unlinked autosomal markers that exhibit similar power of discrimination values [4]

The demonstration of partial and week GD between HTG4 and HMS3 warns against the inadequate inclusion of linked markers in the calculation of combined power of discrimination for parentage validation of Thoroughbred horses. Corroborating our results on GD, two association studies demonstrated interallelic non-random associations involving the HTG4 locus to a syntenic five-base-pair deletion frameshift mutation at the DNA-dependent protein kinase catalytic subunit (DNAPK) gene located on ECA9 (GeneID: 791233; NC_009152:35,369,306-35,569,831) $[21,22]$. Worthy of note, DNAPK maps further downstream to the HMS3 locus. Altogether, these data indicate that GD on this chromosomal region extends at least $30 \mathrm{Mb}$. A recent genome-wide study on linkage disequilibrium in the Thoroughbred horse used over 50,000 single nucleotide polymorphism (SNP) markers [23], 1,963 of which map to ECA9, to reveal that gametic disequilibrium extends over long distances, with average values maintained above non-syntenic levels for markers up to $20 \mathrm{Mb}$ apart.

The common practice of including closely linked markers for computing cumulative probability of exclusion $[13,24-27]$ should be viewed with great caution. Given the sex-averaged genetic map length of $104,9 \mathrm{cM}$ estimated for ECA9 [7], the product rule seems suitable only to compute combined probabilities from no more than three points, each one mapping $>50 \mathrm{cM}$ apart, which underlines independent segregation [4]. Thus, concerning the determination of combined exclusion probabilities in kinship analysis of Thoroughbred horses, we submit the substitution of the least informative HTG4 marker from the ISAG recommended panel for another marker distant at least $50 \mathrm{cM}$ or located on another autosome.

Lastly, it is also important to recognize that the extent and frequency of GD can vary in different breeds and populations subsets, and that Thoroughbred horses have much less genetic variation than non-Thoroughbred horses $[2,15]$. Therefore, further studies are required to assess GD between the HTG4 and HMS3 loci in other horse breeds.

Acknowledgments This study was supported by grants and fellowships from CNPq (to EM-A), FAPERJ (to EM-A), FAPESP (to FBM) and Núcleo de Diagnóstico e Investigação Molecular of the Universidade Estadual do Norte Fluminense Darcy Ribeiro.

Conflict of interest None.

\section{References}

1. ISAG (2008) Equine Genetics and Parentage Testing Standardization Workshop Report. http://www.isag.us/Docs/ISAG2008 EquineParentage.pdf. Accessed 5 May 2011

2. Tozaki T, Kakoi H, Mashima S, Hirota K, Hasegawa T, Ishida N, Miura N, Choi-Miura NH, Tomita M (2001) Population study and validation of paternity testing for Thoroughbred horses by 15 microsatellite loci. J Vet Med Sci 63:1191-1197

3. Butler JM (2006) Genetics and genomics of core short tandem repeat loci used in human identity testing. J Forensic Sci 51:253-265 
4. Medina-Acosta E, Machado FB (2010) Eyes wide open: the (mis)use of combined power of discrimination for X-linked short tandem repeats. Mol Biol Rep. doi:10.1007/s11033-010-0518-z

5. Mueller LD (2008) Can simple population genetic models reconcile partial match frequencies observed in large forensic databases? J Genet 87:101-108

6. Zapata $\mathrm{C}(2000)$ The $\mathrm{D}^{\prime}$ measure of overall gametic disequilibrium between pairs of multiallelic loci. Evolution 54:1809-1812

7. Swinburne JE, Boursnell M, Hill G, Pettitt L, Allen T, Chowdhary B, Hasegawa T, Kurosawa M, Leeb T, Mashima S, Mickelson JR, Raudsepp T, Tozaki T, Binns M (2006) Single linkage group per chromosome genetic linkage map for the horse, based on two three-generation, full-sibling, crossbred horse reference families. Genomics 87:1-29

8. Dimsoski P (2003) Development of a 17-plex microsatellite polymerase chain reaction kit for genotyping horses. Croat Med $44: 332-335$

9. van de Goor LH, Panneman H, van Haeringen WA (2010) A proposal for standardization in forensic equine DNA typing: allele nomenclature for 17 equine-specific STR loci. Anim Genet 41:122-127

10. Lewontin RC (1988) On measures of gametic disequilibrium. Genetics 120:849-852

11. Lewontin RC (1964) The interaction of selection and linkage I. General considerations; heterotic models. Genetics 49:49-67

12. Lewontin RC (1964) The interaction of selection and linkage. II. Optimum models. Genetics 50:757-782

13. Lee SY, Cho GJ (2006) Parentage testing of Thoroughbred horse in Korea using microsatellite DNA typing. J Vet Sci 7:63-67

14. Sun X, Yan M, Zhang Y, Zhou X, Wang C, Zheng F, Xiong C (2006) Practical application of fluorescent quantitative PCR on trisomy 21 in Chinese Han population. Mol Biol Rep 33:167-173

15. Wade CM, Giulotto E, Sigurdsson S, Zoli M, Gnerre S, Imslan F, Lear TL, Adelson DL, Bailey E, Bellone RR, Blocker H, Dist O, Edgar RC, Garber M, Leeb T, Mauceli E, MacLeod JN, Penedo MC, Raison JM, Sharpe T, Vogel J, Andersson L, Antczak DF, Biagi T, Binns MM, Chowdhary BP, Coleman SJ, Della Valle G, Fryc S, Guerin G, Hasegawa T, Hill EW, Jurka J, Kiialainen A, Lindgren G, Liu J, Magnani E, Mickelson JR, Murray J, Nergadze SG, Onofrio R, Pedroni S, Piras MF, Raudsepp T, Rocchi M, Roed KH, Ryder OA, Searle S, Skow L, Swinburne JE, Syvanen AC, Tozaki T, Valberg SJ, Vaudin M, White JR, Zody MC, Lander ES, Lindblad-Toh K (2009) Genome sequence, comparative analysis, and population genetics of the domestic horse. Science 326:865-867

16. Fujita PA, Rhead B, Zweig AS, Hinrichs AS, Karolchik D, Cline MS, Goldman M, Barber GP, Clawson H, Coelho A, Diekhans M, Dreszer TR, Giardine BM, Harte RA, Hillman-Jackson J, Hsu F, Kirkup V, Kuhn RM, Learned K, Li CH, Meyer LR, Pohl A, Raney BJ, Rosenbloom KR, Smith KE, Haussler D, Kent WJ (2011) The UCSC genome browser database: update 2011 Nucleic Acids Res 39:D876-D882
17. Sayers EW, Barrett T, Benson DA, Bolton E, Bryant SH, Canese K, Chetvernin V, Church DM, DiCuccio M, Federhen S, Feolo M, Fingerman IM, Geer LY, Helmberg W, Kapustin Y, Landsman D, Lipman DJ, Lu Z, Madden TL, Madej T, Maglott DR, Marchler-Bauer A, Miller V, Mizrachi I, Ostell J, Panchenko A, Phan L, Pruitt KD, Schuler GD, Sequeira E, Sherry ST, Shumway M, Sirotkin K, Slotta D, Souvorov A, Starchenko G, Tatusova TA, Wagner L, Wang Y, Wilbur WJ, Yaschenko E, Ye J (2011) Database resources of the National Center for Biotechnology Information. Nucleic Acids Res 39:D38-D51

18. Lewis PO, Zaykin DV (2001) Genetic Data Analysis: Computer program for the analysis of allelic data. Version 1.1 (d16c). [Free program distributed by the authors over the internet]. http:// www.eeb.uconn.edu/people/plewis/software.php. Accessed 5 May 2011

19. Gaunt TR, Rodriguez S, Zapata C, Day IN (2006) MIDAS: software for analysis and visualisation of interallelic disequilibrium between multiallelic markers. BMC Bioinform 7:227-237

20. Zapata C, Rodriguez S, Visedo G, Sacristan F (2001) Spectrum of nonrandom associations between microsatellite loci on human chromosome 11p15. Genetics 158:1235-1251

21. Bailey E, Reid RC, Skow LC, Mathiason K, Lear TL, McGuire TC (1997) Linkage of the gene for equine combined immunodeficiency disease to microsatellite markers HTG8 and HTG4; synteny and FISH mapping to ECA9. Anim Genet 28:268-273

22. Finno CJ, Spier SJ, Valberg SJ (2009) Equine diseases caused by known genetic mutations. Vet J 179:336-347

23. Corbin LJ, Blott SC, Swinburne JE, Vaudin M, Bishop SC, Woolliams JA (2010) Linkage disequilibrium and historical effective population size in the Thoroughbred horse. Anim Genet 41(2):8-15. doi:10.1111/j.1365-2052.2010.02092.x

24. Luis C, Cothran EG, Oom Mdo M (2002) Microsatellites in Portuguese autochthonous horse breeds: usefulness for parentage testing. Genet Mol Biol 25:131-134

25. Zabek T, Nogaj A, Radko A, Nogaj J, Slota E (2005) Genetic variation of polish endangered Bilgoraj horses and two common horse breeds in microsatellite loci. J Appl Genet 46:299-305

26. Behl R, Behl J, Gupta N, Gupta SC, Ahlawat SP, Ragnekar M, Ahmed Z (2006) Genetic characterization of Zanskari breed of horse. J Genet 85:199-203

27. Choi SK, Cho CY, Yeon SH, Cho BW, Cho GJ (2008) Genetic characterization and polymorphisms for parentage testing of the Jeju horse using 20 microsatellite loci. J Vet Med Sci 70:1111-1115

28. Benson G (1999) Tandem repeats finder: a program to analyze DNA sequences. Nucleic Acids Res 27:573-580

29. Matise TC, Chen F, Chen W, De La Vega FM, Hansen M, He C, Hyland FC, Kennedy GC, Kong X, Murray SS, Ziegle JS, Stewart WC, Buyske S (2007) A second-generation combined linkage physical map of the human genome. Genome Res 17:1783-1786 


\title{
Eyes wide open: the (mis)use of combined power of discrimination for $\mathrm{X}$-linked short tandem repeats
}

\author{
Enrique Medina-Acosta $\cdot$ Filipe Brum Machado
}

Received: 12 October 2010/Accepted: 13 November 2010/Published online: 26 November 2010

(c) Springer Science+Business Media B.V. 2010

In the field of Genetic Epidemiology it is well established that ignoring interallelic multipoint gametic disequilibrium (GD) introduces false-positive evidence of linkage for sibpair (kinship) analysis, especially in cases of sample deficiencies [1]. In the field of Forensic Genetics this proven concept is, in stark contrast, largely trivialized or ignored. There is an alarming accrual of forensic reports (Online Resource 1) announcing population data on short tandem repeats loci mapping on X chromosome (X-STRs) in which the product rule is applied to syntenic loci (i.e., being located on the same chromosome whether or not there is demonstrable genetic linkage between them), mostly ignoring the second law of Mendelian inheritance, and fundamental notions on genetic linkage status. We believe that the issue has been utterly disregarded, and thus it can no longer go unnoticed without opinion.

Electronic supplementary material The online version of this article (doi:10.1007/s11033-010-0518-z) contains supplementary material, which is available to authorized users.

E. Medina-Acosta

Núcleo de Diagnóstico e Investigação Molecular,

Universidade Estadual do Norte Fluminense Darcy Ribeiro, Avenida Alberto Lamego 2000, Parque Califórnia, Campos dos Goytacazes, RJ CEP 28013-602, Brazil

\section{F. B. Machado}

Departamento de Genética, Faculdade de Medicina de Ribeirão Preto, Universidade de São Paulo, Avenida Bandeirantes, 3900, Monte Alegre, Ribeirão Preto, SP CEP 14049-900, Brazil

E. Medina-Acosta $(\bowtie)$

Laboratório de Biotecnologia, Centro de Biociências e

Biotecnologia, Universidade Estadual do Norte Fluminense Darcy Ribeiro, Avenida Alberto Lamego 2000, Parque Califórnia, Campos dos Goytacazes, RJ CEP 28013-602, Brazil e-mail: quique@uenf.br
We center our opinion at the most crucial aspect that underlies meaningful calculation of combined power of discrimination (CPD), as it applies to forensic and medical genetics: accurate knowledge about genetic linkage status of X-STRs loci [2].

$\mathrm{X}$ chromosome is endowed with distinctive characteristics mainly derived from how it is inherited by male and female offspring. Contrasting to autosomes, and excluding the pseudoautosomal regions present in both $\mathrm{X}$ and $\mathrm{Y}$ chromosomes, $\mathrm{X}$ chromosome recombination only occurs in females, so every existing $\mathrm{X}$ chromosome has evolved two-thirds of its history in them [3].

Syntenic loci may, in principle, be subjected to GD, which is a multifactorial evolutionary dynamic phenomenon that occurs at normal selection, characterized by significant and intensity-variable non-random associations of alleles at different DNA loci, physically mapped on the same (even though not necessarily) chromosomal DNA molecule [4]. GD is affected by, and therefore it is an indicator of, extreme allele frequencies, allele mutation rate, selection, genetic drift, gene flow, recombination, admixture, and the demographic history of populations [5].

A first conundrum with typing syntenic X-STRs loci is whether, and if so how, to compute the genotype evidence (phased our unphased diplotypes and male haplotypes) in favor of a matching hit (i.e., coinciding profiles) or against it (i.e., allelic exclusion). Solving this riddle will help responding the practical question "what is the evidential value of an X haplotype?" This problem is of considerable lesser extent in relation to the field of YSTRs haplotypes [6], from which important lessons ought to be learned.

It helps to keep in mind that matching haplotypes can reflect either "identity by descend" (IBD; i.e., related haplotypes with no intervening mutations) or "identity by 


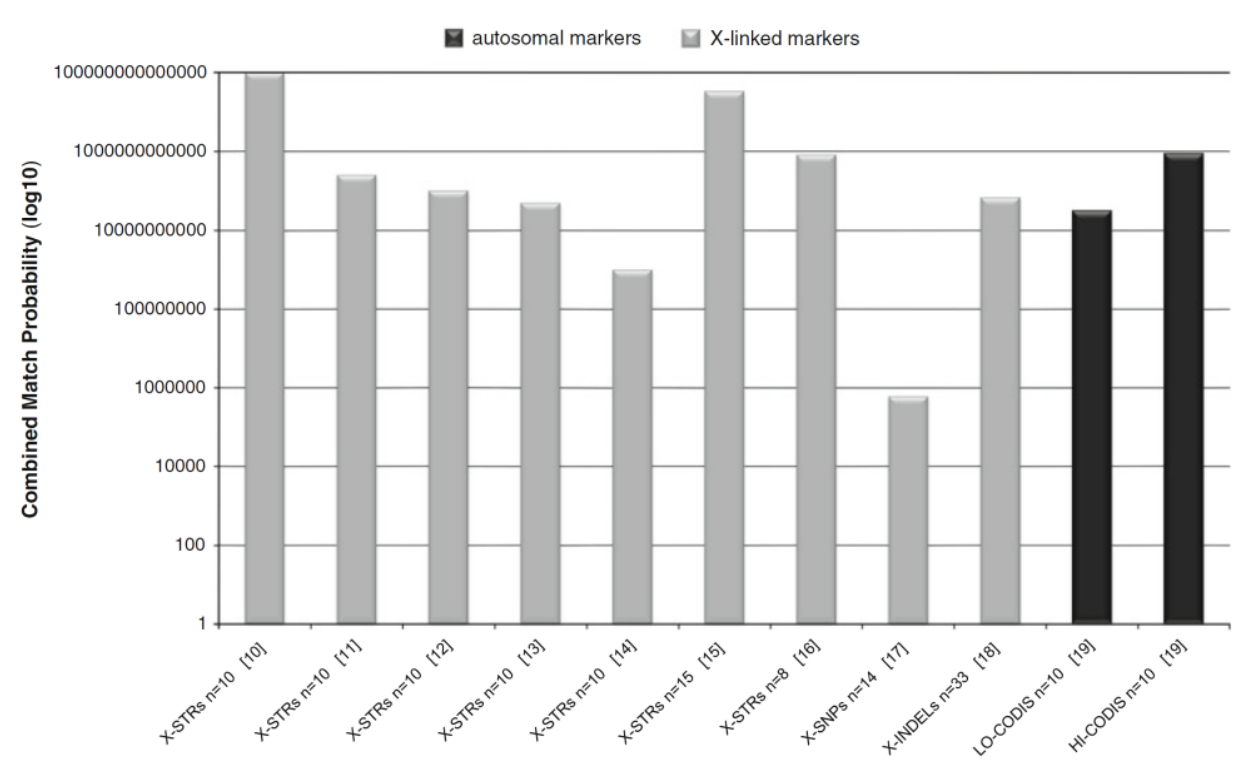

Fig. 1 Distribution of combined match probability (CMP) values, calculated using combined power of discrimination (CPD) data reported in nine studies on X-linked markers (clear shaded bars). For comparison, CMP values using the highest (HI) and the lowest (LO) CODIS PD values (dark shaded bars) are shown. Studies are identified by the reference number in brackets; $n$ is the number of

state" (IBS; i.e., same haplotype may be coincidentally) [6]. Pertinent forensic questions to confront then arise: "Do haplotypes match because they are IBD or IBS? What is the evidentiary value of the DNA match itself? What is the probative value of DNA evidence?", particularly in light of the existence or quality of other corroborating (genetic or not) evidence $[6,7]$.

In contrast to the non-recombining Y-STRs loci, an important issue in determining combined exclusion probabilities is the genetic linkage status of syntenic $\mathrm{X}$-STRs loci, which may affect reliable use of the product rule in estimating random match probabilities. The product rule refers to the mathematical combination of locusspecific match probabilities. It is intended to decrease the odds of a random match to an unrelated individual, and it involves the assumption that loci combine at random [8]. Surprisingly, most authors announcing population data on forensic X-STRs loci submit that the product rule can be applied to syntenic markers, despite evidence on GD between syntenic X-STRs markers [2, 9], and persist in calculating CPD (Online Resource 1). Most importantly, in the case of extensively linked loci (i.e., when haplotypes become analogous to alleles), misspecification of haplotype frequencies is a major caveat against the use of markers per system. The $y$-axis is CMP $\left(\log _{10}\right)$. Note that the application of the product rule to X-linked loci leads to incongruent profile frequencies (i.e., 1 in 1 trillion for a system with eight X-STRs), approaching or even exceeding the frequencies obtained using the CODIS. The complete list of marker systems used in the source studies is available from Online Resource 2

haplotype probabilities analogously to genotype probabilities [1].

We wish to emphasize on the risk of misusing the product rule at genetic linked loci, by illustrating the impact of such estimates, using CPD data from seven representative studies on X-STRs loci [10-16]. We restricted the analysis to female datasets, and included CPD data from two studies on X-SNPs [17] and X-INDELs [18], and one study on autosomal STRs [19]. For autosomes, the STRs loci comprising the Combined DNA Index System (CODIS) were considered, except for CSF1PO which is syntenic with D5S818. For comparisons, the 10 highest (HI) and the 10 lowest (LO) CODIS PD values were used to calculate the autosomal CPD. We then plotted combined match probabilities (CMP) (Fig. 1). This exercise showed that applying the product rule to $\mathrm{X}$-linked loci yields CMP values that approach or even exceed CMP values that were generated using autosomal truly unlinked STRs loci. Thus, by ignoring linkage disequilibrium typing laboratories erroneously claim that their X-STRs marker sets offer comparable, if not greater, discriminatory power than typing with an equal number of unlinked autosomal markers that exhibit similar PD values. Under this reasoning, for the set of markers commonly used, virtually every female and 
male would yield a rare (even a unique) $\mathrm{X}$ chromosome profile (phase diplotype or haplotype, respectively). Notwithstanding worldwide haplotype frequency data evidence against independence of X-STRs loci, the erroneous habit of applying the product rule to linked markers spreads reluctantly in the forensic field.

Worth of note, considering the genetic map length $(196 \mathrm{cM})$ of the human $\mathrm{X}$ chromosome [20], the product rule would be suitable only to compute CPD values from no more than four points (whether single loci or groups of contiguous loci, the latter in extensive GD), each point mapping $>50 \mathrm{cM}$ apart. Nonetheless, the mean number of crossovers on $\mathrm{X}$ chromosome is 3.22 per meiosis, as directly estimated in human oocytes [21]. We feel that, for the markers commonly used in forensic practice, it urges to indentify specific multiallelic interallelic associations, their frequency and strength, which can be measured, for example, using $D^{\prime}$ coefficient [2]. We caution that tests of statistical significance ( $P$ values) are not measures of GD.

A second conundrum is whether, and if so how, to compute mutation. For X-STRs loci, this issue has not been systematically addressed. Microsatellite instability impacts kinship analysis, because mutations, as well as recombination, breakdown GD and, with time, they may cause unrelated haplotypes to converge at IBS.

Notwithstanding the extensive use by many laboratories worldwide, there is a lack of comprehensive and largescale studies about the meiotic stability for any of the X-STRs loci $[22,23]$. A throughout study on the stability of microsatellites will require typing of large number of extended pedigrees or, more frequently, a large number of nuclear family trios (mother-child-father). For example, for the 13 CODIS autosomal STRs loci apparent mutation rates have been determined in nearly 1 million meioses per loci (American Association of Blood Banks 2003 Annual Report available at: http://www.cstl.nist.gov/strbase/mutation. $\mathrm{htm}$ ). This volume of information compiles multiple years, with 44 different paternity testing laboratories providing data. Thus, for the X-STRs loci, information on stability falls far behind their utilization in population genetics. Unfortunately, discrepancies in size of the transferred XSTRs alleles (i.e., allelic inconsistencies) observed in nuclear families are currently not integrated in a public database for analysis. We believe that a trend towards typing nuclear families will offer the advantage of effectively increasing knowledge about marker stability, albeit reducing the number of unrelated individuals.

The opinions and questions posed here, obviously, are not intended to question the relevance and significance of typing X-STRs loci, with the purpose of identifying, characterizing and developing DNA markers for forensic and population genetics.

\section{References}

1. Huang Q, Shete S, Amos CI (2004) Ignoring linkage disequilibrium among tightly linked markers induces false-positive evidence of linkage for affected sib pair analysis. Am J Hum Genet 75:1106-1112

2. Medina-Acosta E (2010) Evidence of partial and weak gametic disequilibrium across clusters of pericentromeric short tandem repeats loci on human X chromosome: Proceed with caution in forensic genetics. Forensic Sci Int Genet. doi:10.1016/j.fsigen. 2009.12.002

3. Schaffner SF (2004) The X chromosome in population genetics. Nat Rev Genet 5:43-51. doi:10.1038/nrg 1247

4. Hedrick PW (1987) Gametic disequilibrium measures: proceed with caution. Genetics 117:331-341

5. Lewontin RC (1964) The interaction of selection and linkage I. general considerations; heterotic models. Genetics 49:49-67

6. Brenner $\mathrm{CH}$ (2010) Fundamental problem of forensic mathematics - the evidential value of a rare haplotype. Forensic Sci Int Genet. doi:10.1016/j.fsigen.2009.10.013

7. Pinto N, Gusmao L, Amorim A (2010) X-chromosome markers in kinship testing: a generalisation of the IBD approach identifying situations where their contribution is crucial. Forensic Sci Int Genet. doi:10.1016/j.fsigen.2010.01.011

8. Butler JM (2006) Genetics and genomics of core short tandem repeat loci used in human identity testing. J Forensic Sci 51:253-265. doi:10.1111/j.1556-4029.2006.00046.x

9. Tillmar AO, Mostad P, Egeland T, Lindblom B, Holmlund G, Montelius K (2008) Analysis of linkage and linkage disequilibrium for eight X-STR markers. Forensic Sci Int Genet 3:37-41. doi:10.1016/j.fsigen.2008.09.006

10. Aler M, Sanchez-Diz P, Gomes I, Gisbert M, Carracedo A, Amorim A, Gusmao L (2007) Genetic data of 10 X-STRs in a Spanish population sample. Forensic Sci Int 173:193-196. doi: 10.1016/j.forsciint.2006.10.023

11. Pereira R, Gomes I, Amorim A, Gusmao L (2007) Genetic diversity of $10 \mathrm{X}$ chromosome STRs in northern Portugal. Int J Legal Med 121:192-197. doi:10.1007/s00414-006-0144-4

12. Pico A, Castillo A, Vargas C, Amorim A, Gusmao L (2008) Genetic profile characterization and segregation analysis of $10 \mathrm{X}$ STRs in a sample from Santander, Colombia. Int J Legal Med 122:347-351. doi:10.1007/s00414-007-0215-1

13. Gusmão L, Sanchez-Diz P, Alves C, Gomes I, Zarrabeitia MT, Abovich M, Atmetlla I, Bobillo C, Bravo L, Builes J, Caine L, Calvo R, Carvalho E, Carvalho M, Cicarelli R, Catelli L, Corach D, Espinoza M, Garcia O, Malaghini M, Martins J, Pinheiro F, Joao Porto M, Raimondi E, Riancho JA, Rodriguez A, Rodriguez Cardozo B, Schneider V, Silva S, Tavares C, Toscanini U, Vullo C, Whittle M, Yurrebaso I, Carracedo A, Amorim A (2009) A GEP-ISFG collaborative study on the optimization of an X-STR decaplex: data on 15 Iberian and Latin American populations. Int J Legal Med 123:227-234. doi:10.1007/s00414-008-0309-4

14. Bobillo C, Sala A, Gusmao L, Corach D (2010) Genetic analysis of 10 X-STRs in Argentinian population. Forensic Sci Int Genet. doi:10.1016/j.fsigen.2009.11.005

15. Nakamura Y, Minaguchi K (2010) Sixteen X-chromosomal STRs in two octaplex PCRs in Japanese population and development of 15-locus multiplex PCR system. Int J Legal Med. doi:10.1007/ s00414-010-0467-z

16. Tie J, Uchigasaki S, Oshida S (2010) Genetic polymorphisms of eight X-chromosomal STR loci in the population of Japanese. Forensic Sci Int Genet 4:e105-e108. doi:10.1016/j.fsigen.2009. 09.002

17. Li L, Li C, Zhang S, Zhao S, Liu Y, Lin Y (2010) Analysis of 14 highly informative SNP markers on X chromosome by TaqMan ${ }^{\circledR}$ 
SNP genotyping assay. Forensic Sci Int Genet 4(5):e145-e148. doi:10.1016/j.fsigen.2010.04.004

18. Freitas NS, Resque RL, Ribeiro-Rodrigues EM, Guerreiro JF, Santos NP, Ribeiro-Dos-Santos A, Santos S (2010) X-linked insertion/deletion polymorphisms: forensic applications of a 33markers panel. Int J Legal Med 124(6):589-593, doi:10.1007/ s00414-010-0441-9

19. Rodrigues EL, Machado FB, Arruda MM, de Moura-Neto RS, Medina-Acosta E (2009) Genetic data on 15 STR autosomal loc for a sample population of the Northern Region of the State of Rio de Janeiro, Brazil. Forensic Sci Int Genet 4:e25-e26. doi: 10.1016/j.fsigen.2009.01.008

20. Matise TC, Chen F, Chen W, De La Vega FM, Hansen M, He C, Hyland FC, Kennedy GC, Kong X, Murray SS, Ziegle JS, Stewart
WC, Buyske S (2007) A second-generation combined linkage physical map of the human genome. Genome Res 17:1783-1786. doi: $10.1101 / \mathrm{gr} .7156307$

21. Tease C, Hartshorne GM, Hulten MA (2002) Patterns of meiotic recombination in human fetal oocytes. Am J Hum Genet 70: $1469-1479$

22. Fracasso T, Schurenkamp M, Brinkmann B, Hohoff C (2008) An $\mathrm{X}$-STR meiosis study in Kurds and Germans: allele frequencies and mutation rates. Int J Legal Med 122:353-356. doi:10.1007/ s00414-008-0231-9

23. Hering S, Edelmann J, Augustin C, Kuhlisch E. Szibor R (2009) $\mathrm{X}$ chromosomal recombination-a family study analysing 39 STR markers in German three-generation pedigrees. Int J Legal Med markers in German three-generation pedigrees. I 


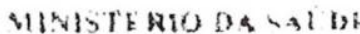

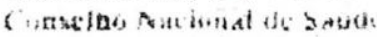

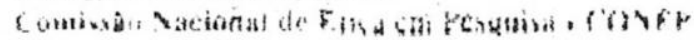

PARECER N $687 / 2000$

Processo n: $25000.003012100-54$

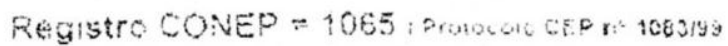

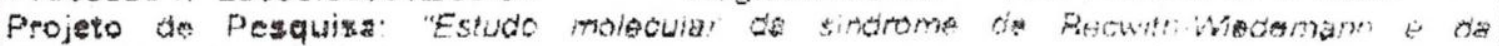
Hamimiperantia isclada.

Pesquisador Resporstuvel: Oru Egle Sllvert Rेarnos

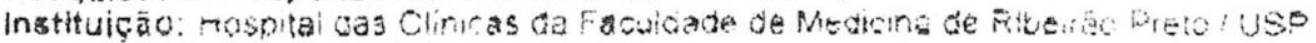

Data dentrada no CONEF: D1/02/2000

Área Temática Especial: Coencetica Humana

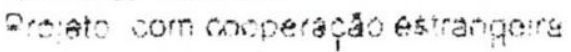

Ao se procader a andibe das rapostas ao paracer CONEp po 14412000 retativo au projeto am questo considerou-se qu

a) Foram gterdidas as solichtabes du roterion parecer

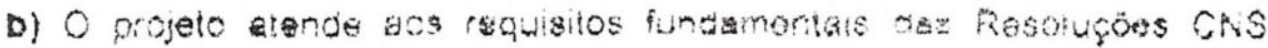

$196 / 96$ a 29296 sobre Detrizes e Nomas Regulamemagoras de Fesousas Envolveras Sgres Humanos

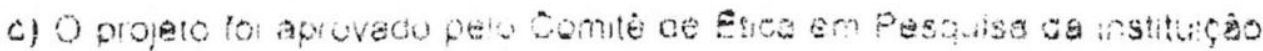
supracitade

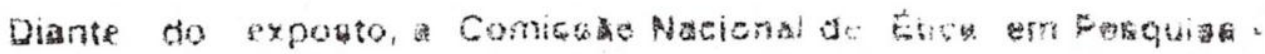
CONEP. de acordo com as meribuiges definidar na Resulucăo CNS $198 / 96$,

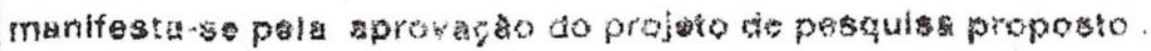

Situaça Pigjoto actorato

Brasta 24 de juth ae 2006

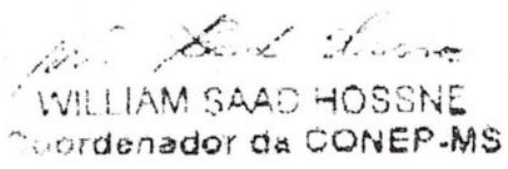




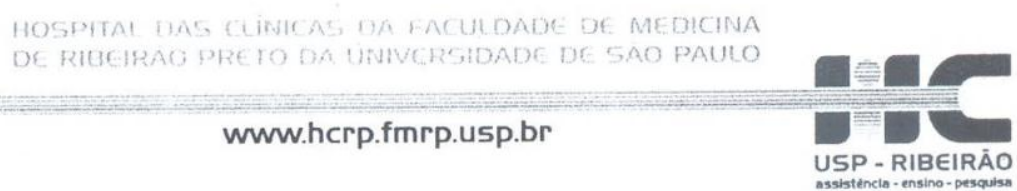

Ribeirão Preto, 16 de abril de 2008

Oficio $\mathrm{n}^{\circ} 1316 / 2008$

$\mathrm{CEP} / \mathrm{SPC}$

Prezada Professora,

O trabalho intitulado "PESQUISA DO PADRÃO DE METILAÇÃO DA REGIÃO 11P15 NA SINDROME DE SILVER-RUSSELL", foi analisado pelo Comitê de Ética em Pesquisa, em sua $264^{a}$ Reunião Ordinária realizada em 14/04/2008, e enquadrado na categoria: APROVADO, bem como o Termo de Consentimento Livre e Esclarecido, de acordo com o Processo HCRP n ${ }^{\circ} 1497 / 2008$.

Este Comitê segue integralmente a Conferência Internacional de Harmonização de Boas Práticas Clinicas (IGH-GCP), bem como a Resolução $n^{\circ}$ 196/96 CNS/MS.

Lembramos que devem ser apresentados a este CEP, 0 Relatório Parcial e o Relatório Final da pesquisa.

Atenciosamente.

PROF. DR. SERGIO PERAIRA DA CUNHA

Coordenador do Comitê de Etica em

Pesquisa do HCRP e da FMRP-USP

Ilustrissima Senhora

PROFª DR ${ }^{a}$ ESTER SILVEIRA RAMOS

Depto. de Genética - FMRP-USP

Comltê de Ética em Pesqulsa HCRP e FMRP-USP - Campus Universitário FWA - 0000 2733; IRB - 00002186 e Registro SISNEP/CONEP n ${ }^{\circ} 4$ Fone (16) 3602-2228 - E-mail : cep(a)hcrp. fimrp.usp.br Monte Alegre 14048-900 Ribeirăo Preto SP 